\title{
Emissions of Greenhouse Gases from the Use of Transportation Fuels and Electricity
}

\section{Volume 1: Main Text}

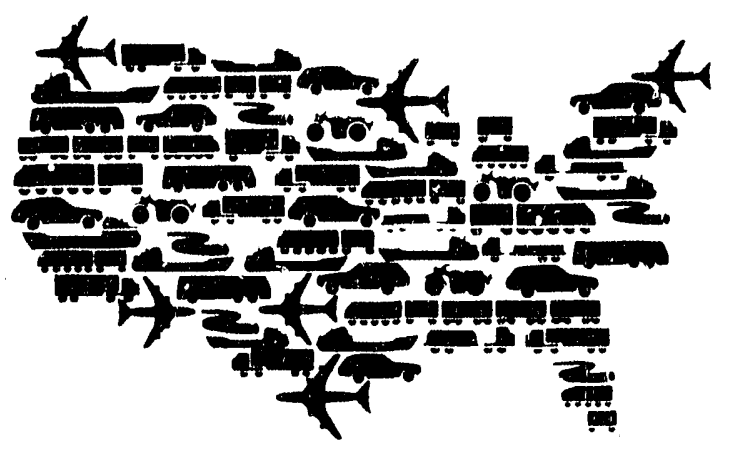

Center for Transportation Research Argonne National Laboratory 


\section{Argonne National Laboratory}

Argonne National Laboratory, with facilities in the states of iunois and Idaho, is owned by the United States govemment, and operatec by the University of Chicago under the provisions of a contract with the Department of Energy.

This technical memo is a pioduct of Argonne's Energy Systems (ES)

Division. For information on the division's scientific and engineering activities, contact:

Director, Energy Systems Division

Argonne National Laboratory

Argonne, Illinois 60439-4815

Telephone (708) 252-3724

Presented in this technical memo are preliminary results of ongoing work or work that is more limited in scope and depth than that described in formal reports issued by the ES Division.

\section{Disclaimer}

This report was prepared as an account of work sponsored by an agency of the United States Govemment. Neither the United States Govemment nor any agency thereof, nor any of their employees, makes any warranty, express or implied, or assumes any legal liability or responsibility for the accuracy, completeness, or usefulness of any information, apparatus, product, or process disclosed, or represents that its use would not infringe privately owned rights. Reference herein to any specific commercial product, process, or service by trade name, trademark, manufacturer, or otherwise, does not necessarily constitute or imply its endorsement, recor,umendation, or favoring by the United States Govemment or any agency thereof. The views and opinions of authors expressed herein do not necessarily state or reflect those of the United States Govemment or any agency thereof.

Reproduced directly from the best available copy.

Available to DOE and DOE cortractors from the Office of Scientific and Tochnical Information, P.O. Box 62, Oak Ridge, TN 37831; prices available from (615) 576-8401, FTS 626-8401.

Available to the public from the National Technical Information Service, U.S. Department of Commerce, 5285 Port Royal Road, Springfield, VA 22161. 


\section{Emissions of Greenhouse Gases from the Use of Transportation Fuels and Electricity}

\section{Volume 1: Main Text}

by M.A. DeLuchi*

Center for Transportation Research, Energy Systems Division,

Argonne National Laboratory, 9700 South Cass Avenue, Argonne, Illinois 60439

November 1991

Work sponsored by

United States Department of Energy,

Deputy Under Secretary for Policy, Planning and Analysis,

Office of Environmental Analysis and

Office of Energy Demand Policy,

Assistant Secretary for Conservation and Renewable Energy,

Office of Transportation Technologies,

United States Department of Transportation and California Department of Transportation,

University of California Transportation Center

"Del uch is affiliated with the Institute of Transportation Studies, University of California, Davis. 


\section{CONTENTS}

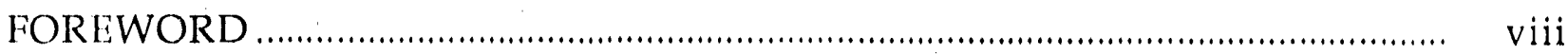

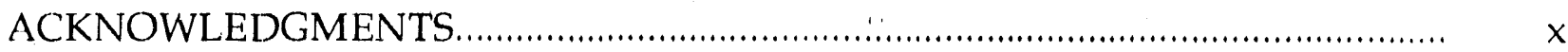

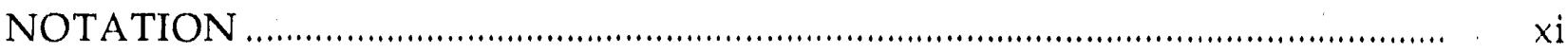

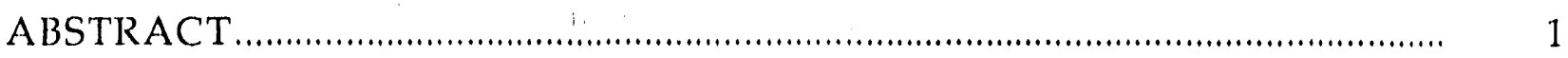

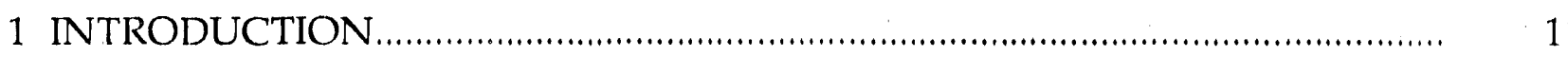

1.1 Need for and Purpose of Report .............................................................

1.2 Organization of Report.......................................................................... 6

1.3 Results of Report ............................................................................... 7

2 GREENHOUSE GASES AND GLOBAL CLIMATE CHANGE ......................... 8

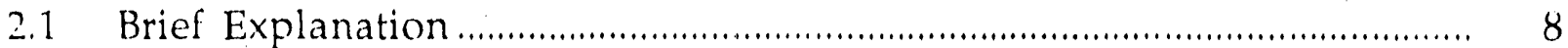

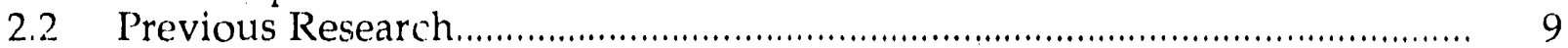

2.2.1 Emissions from Use of Transportation Fuels .................................... 9

2.2.2 Emissions from Use of Fuels to Generate Electricity ...................... 11

2.3 Need for More Research .......................................................................... 11

3 ANALYSIS OF GREENHOUSE GAS EMISSIONS FROM

ELIECTRICITY AND TRANSPORTATION FUEL CYCLES ……....................... 15

3.1 Fuel-Cycle/Stages and Emissions Studied by the Model ............................ 15

3.2 Sources of Data and Methods Used by the Model

to Estimate Emissions, by Fuel-Cycle Stage …….......................................... 16

3.2.1 End Use by Vehicles ................................................................ 16

3.2.2 Fyel Compression or Liquefaction.............................................. 17

3.2.3 Fuel Distribution......................................................................... 17

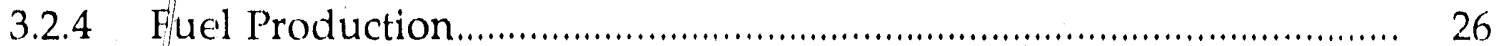

3.2.5 Feedstock Transportation ........................................................ 30

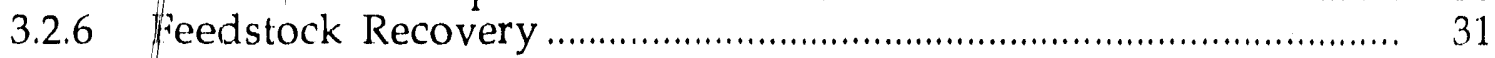

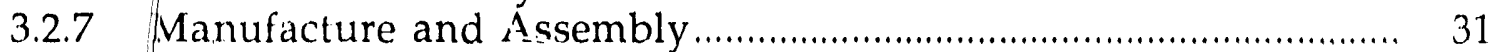

3.3 Parameters Analyzed and Estirnated by the Model.................................... 32

3.3.1 Closed Fuel Cycles....................................................................... 32

3.3.2 Net Energy Available to End Users.................................................. 37

3.3.3 Fate of All Carbon ........................................................................... 37

3.3.4 Gas and Coal Compositions................................................... 37

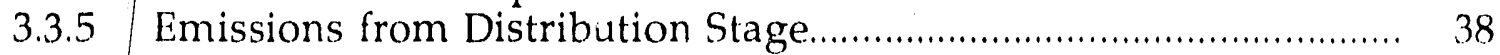

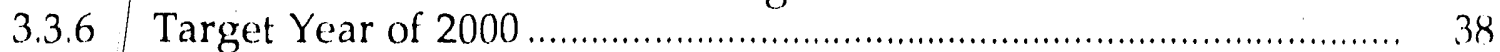

3.3.7 Emissions from Electricity Use .................................................... 39

3.3.8 Actual Fuel Mixes Used to Generate Electricity …......................... 39

3.3.9 Emissions from Nuclear Fuel Cycle ................................................ 40 


\section{CONTENTS (Cont'd)}

3.3.10 Natural Gas Production and 'Transmission.................................. 40

3.3.11 Energy Used to Refine Crude Oil ............................................... 40

3.3.12 Emissions from Wood-Derived Fuels........................................... 41

3.3.13 Corn-to-Ethanol Process ……...................................................... 41

3.3.14 Liquefied Petroleum Gas.......................................................... 42

3.3.15 Reformulated Gasoline and Diesel Fuels........................................ 42

3.3.16 Advanced Battery-Powered and Fuel-Cell-Powered Electric-Motor-Driven Vehicles....................................................... 43

3.3.17 Alternative-Fuel Vehicle Efficiency …….................................... 43

3.3.18 Unusual Sources of Emissions ................................................... 43

3.3.19 Methane and Nitrous Oxide

3.3.20 Venting and Flaring ..................................................................... 44

3.3.21 Nitrogen Oxide, Carbon Monoxide, and Nonmethane Organic Compounds.................................................................. 45

3.3.22 $\mathrm{CO}_{2}$-Equivalent Emissions ....................................................... 45

3.3.23 Light-Duty and Heavy-Duty Vehicles.......................................... 45

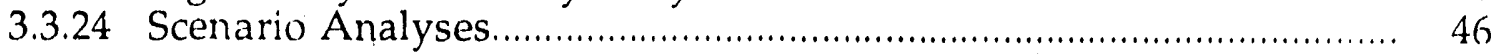

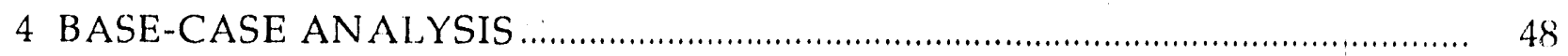

4.1 General Description of Results............................................................. 48

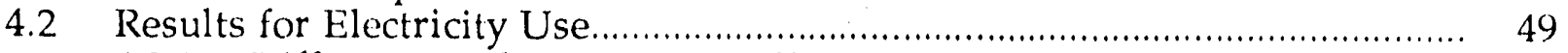

4.2.1 Different Fuels Result in Different Emissions................................. 49

4.2.2 Electricity-Generating Efficiency Correlates with Emissions ........ 52

4.2.3 There Are Several Significant Emission Sources ............................ 52

4.2.4 Coal Fuel Cycle Generates More Methane Emissions than

Does Gas Fuel Cycle ........................................................................... 53

4.2.5 Production and Transport Stages Generate a Lower

Percentage of Emissions in Coal Fuel Cycle than in

Oil or Gas Fuel Cycles.................................................................... 53

4.2.6 Emission Results Vary with the Time Frame.................................... 54

4.2.7 Cutting $\mathrm{NO}_{x}$ and $\mathrm{SO}_{x}$ Emissions Has Less Effect in the

4.2.8 High-Efficiency, Low-NO $\mathrm{NO}_{\mathrm{x}}$, Gasification and Advanced

Gas-Turbine Technologies and Fuel Cells Could Greatly

Reduce Emissions from Electricity Use ......................................... 54

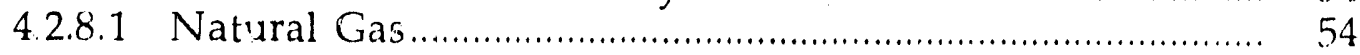

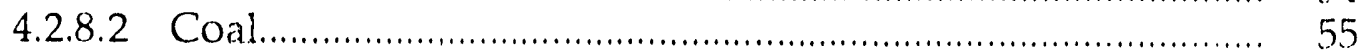

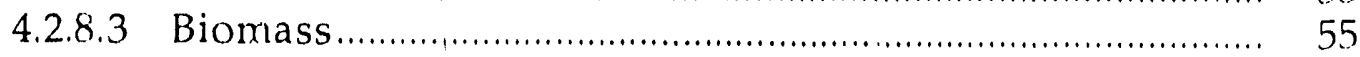

$4.3 \quad$ Results for Vehicular Fuels... .................................................................... 56

4.3.1 Comparison of Emissions from Various Fuel and

Vehicle-Type Combinations with Those from

Base-Case Petroleum-Fuel Vehicles............................................... 56

4.3.1.1 Standard Gasoline ............................................................ 50

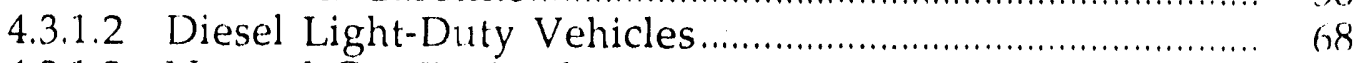

4.3.1.3 Natural-Gas-Derived-Methanol Vehicles ............................. 69 


\section{CONTENTS (Cont'd)}

4.3.1.4 CNG and LNG Vehicles............................................... 70

4.3.1.5 LPG Vehicles................................................................. 71

4.3.1.6 Coal-Derived-Methanol Vehicles ........................................ 71

4.3.1.7 Corn-Derived-Ethanol Vehicles.......................................... 72

4.3.1.8 Wood-Derived-Biofuel Vehicles............................................ $\quad 72$

4.3.1.9 Electric Vehicles ............................................................ 73

4.3.1.10 Internal-Combustion-Engine Vehicles Powered by Nuclear-Made Hydrogen................................................... 74

4.3.1.11 Full-Cell and Internal-Combustion-Engine Vehicles Using Solar-Made Hydrogen.................................................. 74

4.3.1.12 Fuel-Cell Vehicles Using Methanol...................................... 75

4.3.2 Contributions of Individual Greenhouse Gas Emissions to Total Fuel-Cycle Emissions........................................................... 76

4.3.3 Emissions as a Function of Fuel Economy...................................... 79

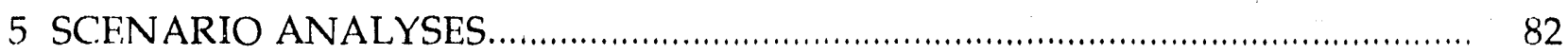

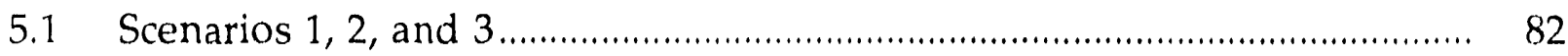

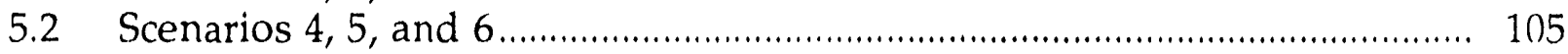

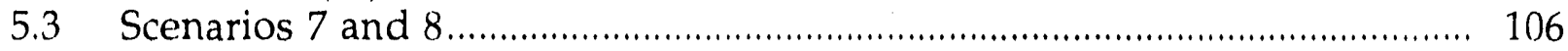

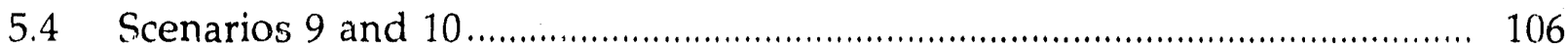

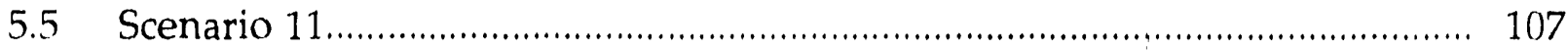

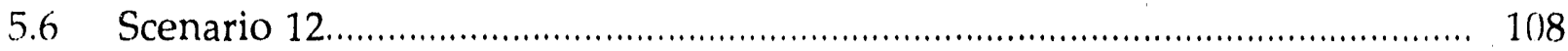

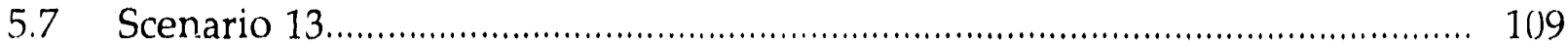

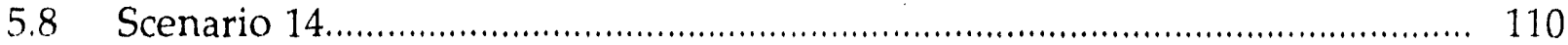

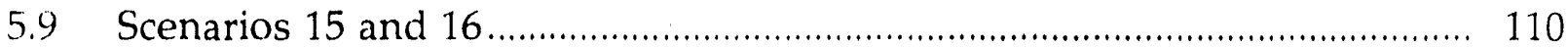

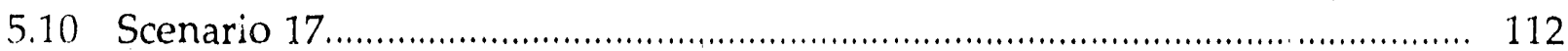

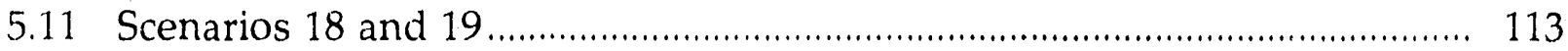

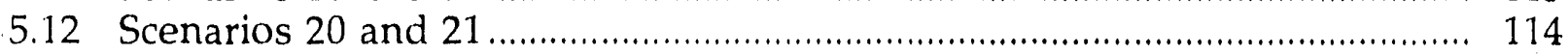

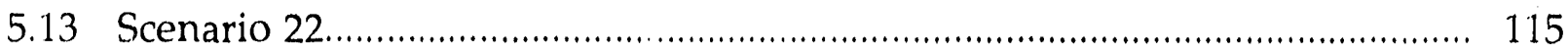

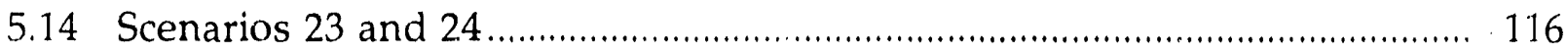

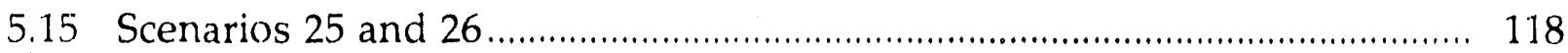

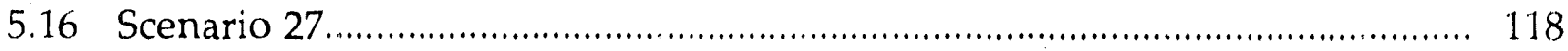

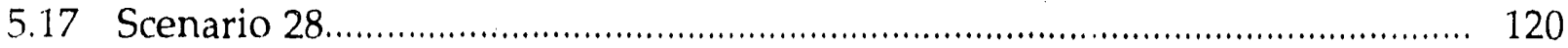

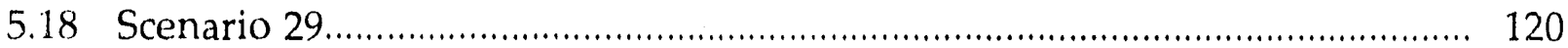

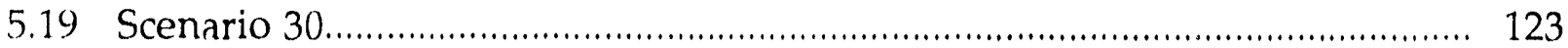

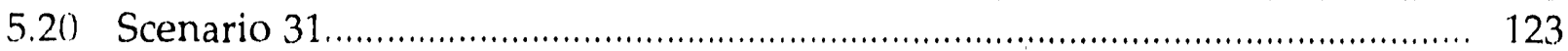

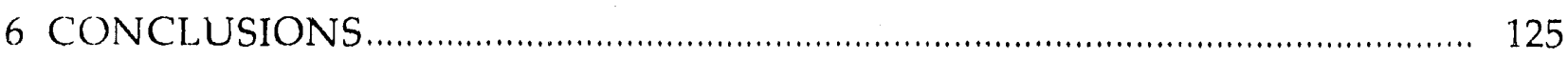

6.1 Transportation Sector Conclusions ...................................................... 125

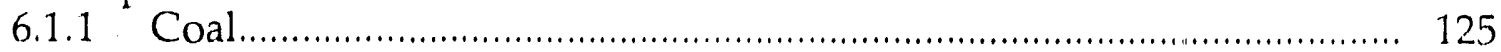

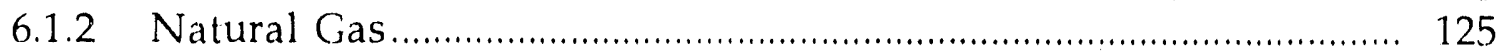

6.1.3 Improved Fuel Economy ........................................................ 126

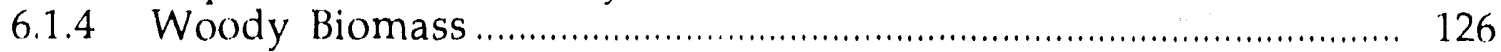

6.1.5 Solar and Nuclear Energy ......................................................... 127 


\section{CONTENTS (Cont'd)}

6.1.6 Non- $\mathrm{CO}_{2}$ Greenhouse Gases ..................................................... 127

6.1.7 Comparative Efficiency of Alternative Fuel Vehicles .................... 128

6.1.8. Comparative Efficiency of Electric Vehicles.................................... 129

6.1.9 Upstream Energy Use.................................................................. 130

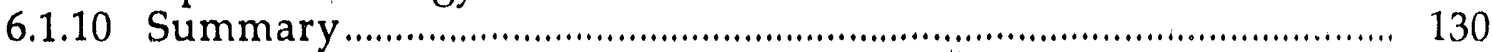

6.2 Overall Conclusions for Transportation and Electricity ........................... 131

6.3 Policy Recommendations for Transportation .......................................... 132

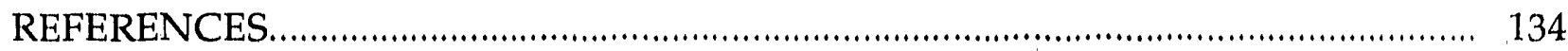

\section{FIGURES}

1 Spans between the Most and Least Favorable Emission Results for Various Electricity-Use Fuel Cycles ............................................................. 50

2 Total Fuel-Cycle, $\mathrm{CO}_{2}$-Equivalent Emissions for Light-Duty Vehicles ............ 67

3 Total Fuel-Cycle, $\mathrm{CO}_{2}$-Equivalent Emissions for Heavy-Duty Vehicles .......... 67

4 Total Fuel-Cycle, $\mathrm{CO}_{2}$-Equivalent Emissions for a Fleet of Light-Duty and Heavy-Duty Vehicles Combined ................................................................ 68

$5 \mathrm{CO}_{2}$-Equivalent Emissions from Vehicle End Use Only …................................ 69

6 Spans between the Most and Least Favorable Emission Results for Various Light-Duty-Vehicie Fuel Cycles....................................................... 102

7 Spans between the Most and Least Favorable Emission Results for Various Heavy-Duty-Vehicle Fuel Cycles.

\section{TABLES}

1 Contribution of Highway Fuel Use to Total $\mathrm{CO}_{2}$ Emissions for Selected Countries

2 Base-Case Input Data Used to Calculate Extra Weight and Overall Relative Efficiency of Alternative-Fuel Vehicles......

3 Base-Case Use of Process Energy at Each Stage of the Fuel Cycles, per Unit of Fuel Energy Made Available to End Users 


\section{TABLES (Cont'd)}

4 Base-Case Breakdown of Process Energy Used at Each Stage of the Fuel Cycles.

5 Base-Case Gas Leaks, Emissions, and Evaporation from Feedstock Recovery and Transport and Fuel Distribution Stages.................................... 27

6 Base-Case Breakdown of Electricity Used by Major Processes in the Fuel Cycles

7 Base-Case $\mathrm{CO}_{2}$-Equivalent Emissions per Unit of Delivered Fuel, by Fuel-Cycle Stage, for 100-Year Time Horizon

8 Factors for Converting Greenhouse Gas Emissions to $\mathrm{CO}_{2}$-Equivalent kimissions, Mass Basis.

9 Brse-Case, Total Fuel-Cycle, $\mathrm{CO}_{2}$-Equivalent Emissions from the Use of Transportation Fuels, by Fuel-Cycle Stage, for 100-Year Time Horizon

10) Base-Case, Total Fuel-Cycle, $\mathrm{CO}_{2}$-Equivalent Emissions from the Use of Transportation Fuels, by Individual Greenhouse Gas, for 1(1)(-Year Time Horizon

11 Base-Case, Total Fuel-Cycle, $\mathrm{CO}_{2}$-Equivalent Emissions from the Use of Transportation Fuels as a Function of Baseline Vehicular Fuel Economy, for 100-Year Time Horizon.

12 Comparison of Total Fuel-Cycle, $\mathrm{CO}_{2}$-Equivalent Emissions from the Use of Alternative Transportation Fuels with Emissions from the Use of Baseline Petroleum Fuels under Different Scenarios

13 Total Fuel-Cycle, $\mathrm{CO}_{2}$-Equivalent Emissions from Electricity Generation as a Function of Net Generation Efficiency, for 20-Year, 100-Year, and 500-Year Time Horizons 


\section{FOREWORD}

Argonne National Laboratory report ANL/ESD/TM-22 consists of two volumes. This first volume summarizes the results of the analyses presented in Volume 2. The second volume, a draft, comprises appendixes that provide detailed explanations and tables for their respective subject areas and a complete reference list of all the documents cited as sources in this report. The contents of the appendixes are as follows:

- Appendix A: Review of General Methods

- Appendix B: Emissions from Vehicles; Spills, Leaks, and Other Losses of Fuel; and Heavy-Duty and Light-Duty Emission Factors Combined

- Appendix C: Fuel Specifications and the Fate of Fuel Carbon

- Appendix D: Electricity Generation and Use

- Appendix E: Energy Use by Trains, Trucks, Ships, and Pipelines

- Appendix F: Coal

- Appendix G: Natural Gás and Natural Gas Liquids

- Appendix H: Petroleum

- Appendix I: Nuclear Energy

- Appendix J: Methanol from Coal and Natural Gas

- Appendix K: Biofuels (Ethanol from Corn and Ethanol, Methanol, and SNG from Wood)

- Appendix L: Hydrogen

- Appendix M: Emissions of Methane from Vehicles, Natural Gas Operations, Oil Production, Coal Mines, and Other Sources

- Appendix N: Emissions of Nitrous Oxide from Vehicles, Power Plants, and Other Sources 
- Appendix O: Converting Emissions of Methane, Nitrous Oxide, Carbon Monoxicie, Nonmethane Hydrocarbons, and Nitrogen Oxides to the Temperature-Equivalent Amount of Carbon Dioxide

- Appendix P: Greenhouse Gas Emissions from Making Material for Vehicles, Power Plants, Pipelines, Ships, Trains, etc., and from Assembling Vehicles

- Appendix Q: Chlorofluorocarbons, Ozone, and Water Vapor

- Appendix R: Scenarios for Europe and Japan

- Appendix S: References for Volumes 1 and 2

Copies of Volume 1 are available from the National Technical Information Service (NTIS), U.S. Department of Commerce, 5285 Port Royal Road, Springfield, Virginia 22161. Copies of the Volume 2 draft are available from Mark DeLuchi, Institute of Transportation Studies, University of California, Davis, California 95616. 


\section{ACKNOWLEDGMENTS}

This report has benefited from reviews by (in alphabetical order): Frank Black, U.S. Environmental Protection Agency; Gene Ecklund, U.S. Department of Energy; Diane Fisher, Environmental Defense Fund; David Hall, Kings College, London; Tom MacDonald, California Energy Commission; Terry Renner, Amoco Oil Corporation; Dan Santini, Argonne National Laboratory (ANL); Mai NguyenMisra, U.S. Environmental Protection Agency; and Stefan Unnasch, Acurex Corporation. I am grateful to Marita Moniger and Florence Henning at ANL for editing this document, and I especially thank Dan Santini for his management skills in overseeing the publication of this report.

Most of the research for this report was supported by a dissertation grant from the University of California Transportation Center, which is funded through the U.S. Department of Transportation and the California Department of Transportation. The U.S. Department of Energy provided funds for the research, review, editing, and publication process, primarily through its Office of Environmental Analysis and also through its Office of Energy Demand Policy, both of which are in the Office of Policy, Planning and Analysis, and through its Office of Transportation Technologies, which is in the Office of Conservation and Renewable Energy.

The estimates made within this report are my own and do not necessarily represent values that are endorsed by any of the reviewers or sponsoring organizations. 


\section{NOTATION}

\section{ACRONYMS}

$\begin{array}{ll}\text { CNG } & \text { compressed natural gas } \\ \text { CSNG } & \text { compressed synthetic natural gas } \\ \text { DDGS } & \text { distillers' dried grains and solubles } \\ \text { DOE } & \text { U.S. Department of Energy } \\ \text { E85 } & \text { 85\% ethanol, 15\% gasoline } \\ \text { EEC } & \text { European Economic Community } \\ \text { EIA } & \text { Energy Information Administration } \\ \text { EPA } & \text { U.S. Environmental Protection Agency } \\ \text { EV } & \text { electric vehicle (battery powered) } \\ \text { FBC } & \text { fluidized-bed combustion } \\ \text { FFV } & \text { Alexible-fuel vehicle } \\ \text { HDV } & \text { heavy'duty vehicle } \\ \text { HIIV } & \text { higher heating value } \\ \text { ICEV } & \text { internal-combustion-engine vehicle } \\ \text { IEA } & \text { International Energy Agency } \\ \text { IGCC } & \text { integrated gasification combined cycle } \\ \text { IPCC } & \text { Intergovernmental Panel on Climate Change } \\ \text { LDV } & \text { light-duty vehicle } \\ \text { LH } 2 & \text { liquefied hydrogen } \\ \text { LNG } & \text { liquefied natural gas } \\ \text { LPG } & \text { liquefied petroleum gas } \\ \text { LPM } & \text { liquid-phase methanol synthesis } \\ \text { M0 } & \text { 0\% methanol, 100\% gasoline } \\ \text { M50 } & \text { 50\% methanol, 50\% gasoline } \\ \text { M85 } & \text { 85\% methanol, 15\% gasoline } \\ \text { M100 } & \text { 100\% methanol } \\ \text { NE } & \text { not estimated } \\ \text { NERC } & \text { North American Electric Reliability Council } \\ \text { NG } & \text { natural gas } \\ \text { NGL } & \text { natural gas liquids } \\ \text { NMHC } & \text { nonmethane hydrocarbon } \\ \text { NMOC } & \text { nonmethane organic compound } \\ & \text { (used interchangeably with NMHC) } \\ \text { NRC } & \text { National Research Council } \\ \text { OECD } & \text { Organization for Economic Cooperation and Development } \\ \text { OTM } & \text { once-through methanol } \\ \text { RVP } & \text { Reid vapor pressure } \\ \text { SNG } & \text { synthetic natural gas } \\ \text { SRIC } & \text { short-rotation intensive cultivation } \\ \text { VMT } & \text { vehicle miles traveled } \\ & \end{array}$




\section{CHEMICALS}

$\begin{array}{ll}\mathrm{C} & \text { carbon } \\ \mathrm{CFC} & \text { chlorofluorocarbon } \\ \mathrm{CFC}-12 & \text { Freon }\left(\mathrm{CF}_{2} \mathrm{Cl}_{2}\right) \\ \mathrm{CH} & \text { methane } \\ \mathrm{CO} & \text { carbon monoxide } \\ \mathrm{CO} & \text { carbon dioxide } \\ \mathrm{Fe} & \text { iron } \\ \mathrm{H}_{2} & \text { hydrogen } \\ \mathrm{MeOH} & \text { methanol } \\ \mathrm{MTBE} & \text { methyl tertiary butyl ether } \\ \mathrm{N}_{2} \mathrm{O} & \text { nitrous oxide } \\ \mathrm{NO}_{\mathrm{x}} & \text { nitrogen cides } \\ \mathrm{O}_{3} & \text { ozone } \\ \mathrm{SO}_{x} & \text { sulfur oxides } \\ \mathrm{Ti} & \text { titanium }\end{array}$

UNITS OF MEASURE

$\begin{array}{ll}\mathrm{ft}^{3} & \text { cubic foot } \\ \mathrm{g} & \text { gram } \\ \mathrm{gal} & \text { gallon } \\ \mathrm{kg} & \text { kilogram } \\ \mathrm{kWh} & \text { kilowatt-hour } \\ \mathrm{L} & \text { liter } \\ \mathrm{lb} & \text { pound } \\ \mathrm{mi} & \text { mile } \\ \mathrm{mpg} & \text { miles per gallon } \\ \mathrm{psi} & \text { pound per square inch } \\ \text { quad } & \text { 1015 Btu } \\ \mathrm{t} & \text { metric ton }(2,200 \mathrm{lb}) \\ \mathrm{Tg} & \text { teragram }\left(10^{12} \text { grams }\right) \\ \text { ton } & \text { short ton }(2,000 \mathrm{lb})\end{array}$




\title{
EMISSIONS OF GREENHOUSE GASES FROM THE USE OF TRANSPORTATION FUELS AND ELECTRICITY'
}

by

\author{
M.A. DeLuchi
}

\begin{abstract}
This report presents estimates of full fuel-cycle emissions of greenhouse gases from using transportation fuels and electricity. The data cover emissions of carbon dioxide $\left(\mathrm{CO}_{2}\right)$, methane, carbon monoxide, nitrous oxide, nitrogen oxides, and nonmethane organic compounds resulting from the end use of fuels, compression or liquefaction of gaseous transportation fuels, fuel distribution, fuel production, feedstock transport, feedstock recovery, manufacture of motor vehicles, maintenance of transportation systems, manufacture of materials used in major energy facilities, and changes in land use that result from using biomass-derived fuels. The results for electricity use are in grams of $\mathrm{CO}_{2}$-equivalent emissions per kilowatt-hour of electricity delivered to end users and cover generating plants powered by coal, oil, natural gas, methanol, biomass, and nuclear energy. The transportation analysis compares $\mathrm{CO}_{2}$-equivalent emissions, in grams per mile, from base-case gasoline and diesel fuel cycles with emissions from these alternative-fuel cycles: methanol from coal, natural gas, or wood; compressed or liquefied natural gas; synthetic natural gas from wood; ethanol from corn or wood; liquefied petroleum gas from oil or natural gas; hydrogen from nuclear or solar power; electricity from coal, uranium, oil, natural gas, biomass, or solar energy, used in battery-powered electric vehicles; and hydrogen and methanol used in fuel-cell vehicles.
\end{abstract}

\section{INTRODUCTION}

\subsection{NEED FOR AND PURPOSE OF REPORT}

In recent years, there has been a considerable amount of interdisciplinary research done on the causes and consequences of global climate change (Bolin et al., 1986; Ramanathan, 1988; MacCracken, 1989; Mahlman, 1989; Climate Change, 1990). Most scientists now believe that an increase in anthropogenic emissions of greenhouse gases -- primarily carbon dioxide $\left(\mathrm{CO}_{2}\right)$, methane $\left(\mathrm{CH}_{4}\right)$, nitrous oxide $\left(\mathrm{N}_{2} \mathrm{O}\right)$, ozone $\left(\mathrm{O}_{3}\right)$ precursors, and chlorofluorocarbons (CFCs) -- will probably change the climate of the earth (Climate Change, 1990). 
As concern about global climate change has grown, evaluating various energy policies in terms of greenhouse gas emissions has become increasingly important. Energy use accounts for a major fraction of all anthropogenic emissions of greenhouse gases (Climate Chunge, 1990). In particular, the use of transportation fuels and electricity accounts for most energy-use-related $\mathrm{CO}_{2}$ emissions (Marland and Pippin, 1990). And in the United States and the other developed countries, $\mathrm{CO}_{2}$. emissions from the use of motor vehicles alone (including emissions from feedstock recovery, processing, and distribution and from vehicle manufacture) have constituted up to $30 \%$ of the total $\mathrm{CO}_{2}$ emissions from the use of all fossil fuels (Table 1).

In the transportation field, concern about the greenhouse effect is coinciding with a serious interest in developing alternatives to gasoline and diesel fuel (DOE, Assessment of Costs and Benefits of Flexible and Alternative Fuel Use in the U.S. Transportation Sector, 1990, and other reports in this series; EPA, August 1990; EPA, September 1989; IEA, Substitute Fuels for Road Transport, 1990; U.S. Congress, Replacing Gasoline, 1990; EPA, Clean Air Act Amendments of 1990, 1990; EPA, Analysis of the Economics and Environmental Effects of Etharol as an Automotive Fuel, 1990; EPA, Analysis of the Economic and Environmental Effects of Compressed Natural Gas as a Vehicle Fuel, 1990). ${ }^{+}$Policymakers and energy malysts want to know if these alternatives -- methanol, ethanol, natural gas (NG), hydrogen, electricity, and liquefied petroleum gas (LPG) -- which can improve urban air qual'ty and reduce the consumption of foreign oil, would also mitigate or exacerbate global warming. Concern about emissions of greenhouse gases is also beginning to figure prominently in the debate over how best to meet the future demand for electricity (DOE Energy Information Administration [EIA], Improving Technology, Modeling Energy Futures for the National Energy Strategy, 1991; IEA, Energy and the Environment, Policy Overview, 1989).

This report is designed to help policymakers and analysts understand the effect of energy options on global climate change, through its analysis of greenhouse gas ernissions from the production, distribution, and use of transportation fuels and electricity in the year 2000. In particular, it is meant to enable a detailed

\footnotetext{
"In most other countries, the use of motor vehicles contributes less to energy-related $\mathrm{CO}_{2}$ emissions than it does in the developed countries of the West. In other countries, the extent of automobile ownership and number of vehicle miles traveled (VMT) per capita are several times smaller than they are in the West. Also, the development of the transportation sector usually lags behind the development of other sectors, such as electricity-generating sectors. These facts suggest that as these countries progress, motor transportation will become an increasingly important sourcc of $\mathrm{CO}_{2}$ emissions in the developing countries of the world.

${ }^{t}$ References are called out in this volume in the same way that they are called out in Volume 2 of this document. Titles or months are given only when more than one document by i particular author that is published in a particular year is listed in App. S, which is the list of references for the entire document. DOE = U.S. Department of Energy; EPA = U.S. Environmental Protection Ag; (ncy; and IEA = International Energy Agency.
} 


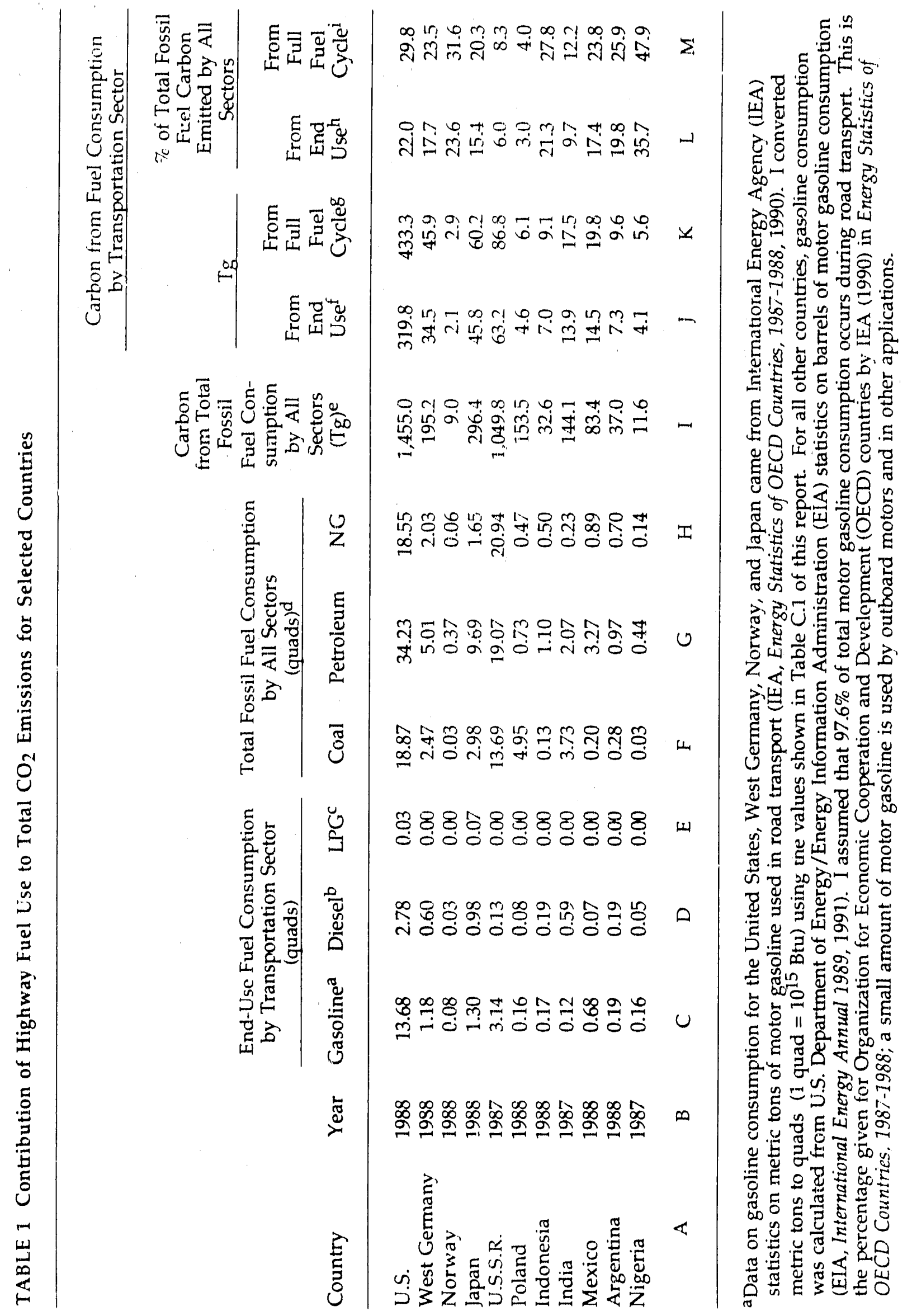




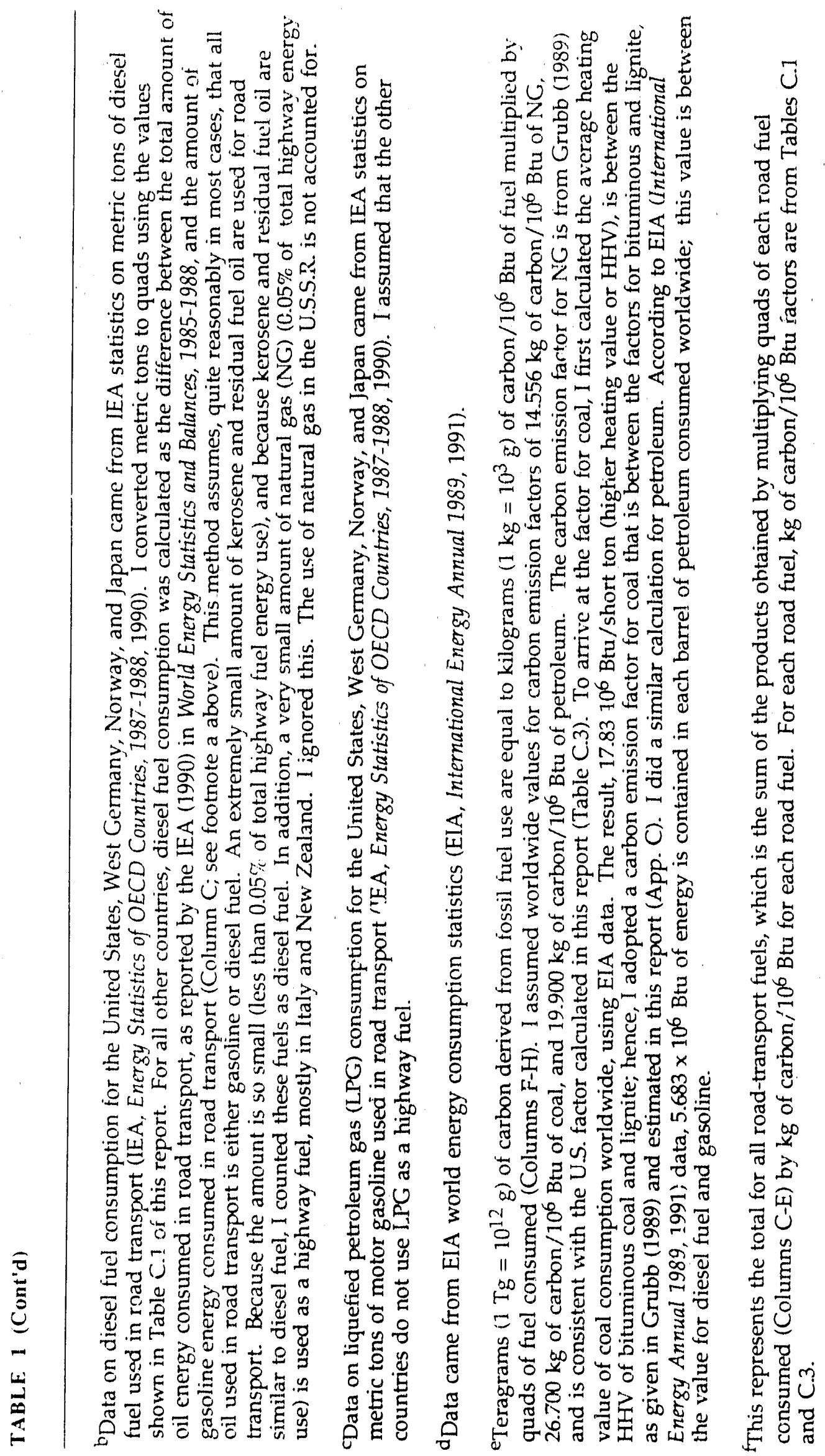




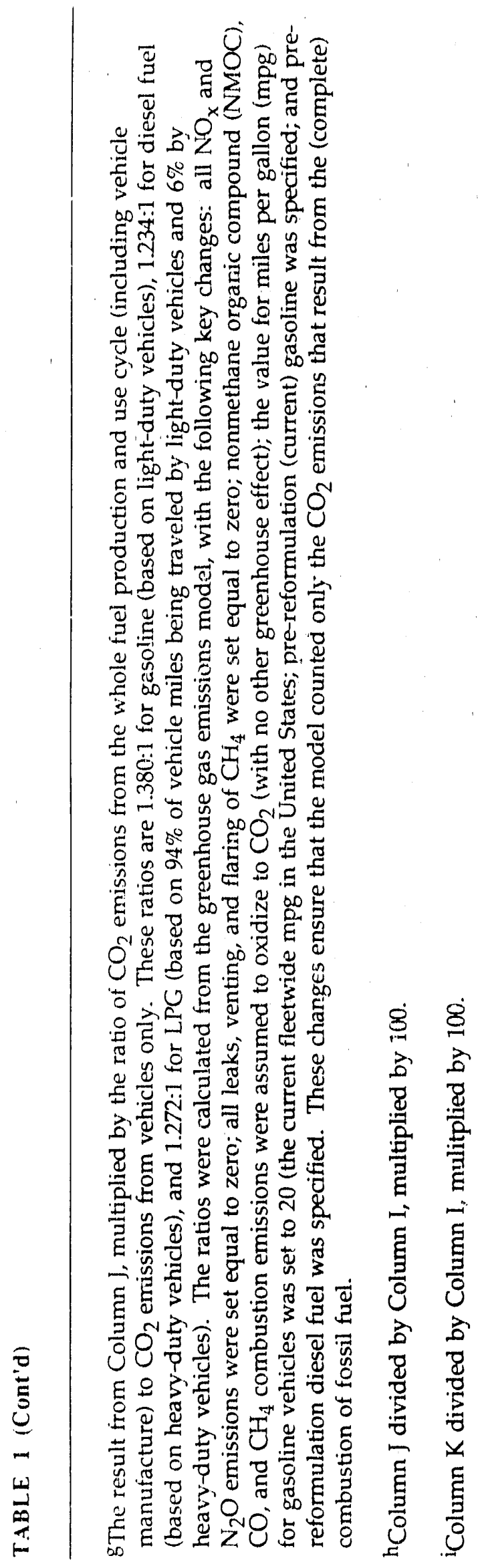


understanding of how specific technological, economic, and tehavioral aspects of the use of energy affect greenhouse gas emissions.

\subsection{ORGANIZATION OF REPORT}

Volume 1, the main text of this report, provides an overview of the analysis that was done; it discusses data sources, the methods used, and results. However, only a few details on the methodology are given in the main text; most of that information is provided in the appendixes. The appendix topics are arranged as follows:

- A: Review of General Methods

- B: Emissions from Vehicles; Spills, Leaks, and Other Losses of Fuel; and Heavy-Duty and Light-Duty Emission Factors Combined

- C: Fuel Srecifications and the Fate of Fuel Carbon

- D: Electricity Generation and Use

- E: Energy Use by Trains, Trucks, Ships, and Pipelines

- F: Coal

- G: Natural Gas and Natural Gas Liquids

- H: Petroleum

- I: Nuclear Energy

- J: Methanol from Coal and Natural Gas

- K: Biofuels (Ethanol from Corn and Ethanol, Methanol, and SNG from Wood)

- L: Hydrogen

- M: Emissions of Methane from Vehicles, Natural Gas Operations, Oil Production, Coal Mines, and Other Sources

- N: Emissions of Nitrous Oxide from Vehicles, Power Plants, and Other Sources

- O: Converting Einissions of Methane, Nitrous Oxide, Carbon Monoxide, Nonmethane Hydrocarbons, and Nitrogen Oxides to the Temperature-Equivalent Amount of Carbon Dioxide 
- P: Greenhouse Gas Emissions from Making Material for Vehicles, Power Plants, Pipelines, Ships, Trains, etc., and from Assembling Vehicles

- Q: Chlorofluorocarbons, Ozone, and $\%$ ater Vapor

- R: Scenarios for Europe and Japan

- S: References for Volumes 1 and 2

\subsection{RESULTS OF REPORT}

This report provides estimates of (1) the amount of energy used in various fuel cycles, (2) the types and amounts of greenhouse gas emissions related to energy production, (3) the types and amounts of greenhouse gas emissions associated with the use of electricity, and (4) the types and amounts of greenhouse gas emissions related to the use of alternative transportation fuels.

The first set of estimates shows the amount of process energy required at each stage of the fuel production and use cycle, per unit of product energy delivered to consumers or power plants. A fuel production and use cycle, or more simply, a fuel cycle, comprises all activities from resource extraction to fuel use by consumers. An example of one of these estimates would be the amount of energy (in Btu) consumed by a tanker truck per Btu of gasoline delivered to a service station. Results are reported for many fuel cycles: for gasoline, diesel fuel, and residual fuel from crude oil; for methanol from coal, NG, and wood; for NG; for synthetic natural gas (SNG) from wood; for ethanol from corn and wood; for LPG from oil or NG; for hydrogen from nuclear power; and for the coal and uranium fuel cycles.

The second set of estimates covers the total $\mathrm{CO}_{2}$-equivalent greenhouse gas emissions that result from the recovery, processing, and delivery of energy products and feedstocks. The results are expressed as grams of $\mathrm{CO}_{2}$-equivalent emissions, at each stage of the fuel cycle (except end-use combustion of the fuel), per million (106) Btu of energy delivered to the consumer. (The concept and derivation of " $\mathrm{CO}_{2}$ equivalency" is explained in App. O.)

The third set of estimates shows the full fuel-cycle $\mathrm{CO}_{2}$-equivalent emissions that result from the use of coal, oil, NG, uranium, biomass, and methanol to generate electricity. These results are expressed in grams of $\mathrm{CO}_{2}$-equivalent emissions per kilowatt-hour ( $\mathrm{kWh})$ delivered to end users.

The fourth set of estimates gives data on the $\mathrm{CO}_{2}$-equivalent emissions that result from the production and use of alternative fuels for transportation. Results are given in grams of $\mathrm{CO}_{2}$-equivalent emissions per mile of travel. Included are the emissions that result from manufacturing the materials to make vehicles and from assembling the vehicles. 


\section{GREENHOUSE GASES AND GLOBAL CLIMATE CHANGE}

\subsection{BRIEF EXPLANATION}

The earth absorbs short-wave radiation from the sun and radiates long-wave infrared energy back to the atmosphere. Water vapor, $\mathrm{CO}_{2}$, and other trace gases absorb most of this sutgoing energy and reradiate some of it back to the surface of the earth. An increase in the concentration of these infrared-absorbing gases will lead to an increase in the total amount of energy in the atmosphere. This warming of the atmosphere could shift global precipitation and temperature patterns, disrupt established crop-growing regions, raise the global mean sea level, increase incidents of severe weather, change the distribution and abundance of biota and pathogens, and, in the long run, melt portions of the polar ice sheets."

$\mathrm{CO}_{2}$ is expected to be responsible for about half of future global warming (Climate Change, 1990). The other infrared-absorbing trace gases $-\mathrm{CH}_{4}, \mathrm{~N}_{2} \mathrm{O}, \mathrm{O}_{3}$, and $\mathrm{CFCs}$-- individually will be less important than $\mathrm{CO}_{2}$, but together will contribute as much to future climate change as will $\mathrm{CO}_{2}$ (Climate Change, 1990). (See Mooney et al., 1987; Bolle et al., 1986; Ramanathan et al., 1985; Wang et al., 1985; Wang and Molnar, 1985 for discussions of these other trace gases.)

The use of energy results in direct emissions of $\mathrm{CO}_{2}, \mathrm{CH}_{4}, \mathrm{~N}_{2} \mathrm{O}, \mathrm{CFC}$, and water vapor. Ozone $\left(\mathrm{O}_{3}\right)$ as such is not emitted directly but rather is formed as a result of a complex series of shemical reactions involving nonmethane organic compounds (NMOCs), carbon monoxide $(\mathrm{CO})$, nitrogen oxides $\left(\mathrm{NO}_{\mathrm{x}}\right)$, and other compounds. In this analysis, emissions of $\mathrm{CO}, \mathrm{NO}_{x}$, and NMOCs are used as a proxy for $\mathrm{O}_{3}$, a procedure that follows the precedent of the Intergovernmental Panel on Climate Change (IPCC) (Shine et al., 1990). These gases, which do not absorb strongly in infrared, affect the concentration of $\mathrm{CO}_{2}$ and $\mathrm{CH}_{4}$ as well as $\mathrm{O}_{3}$.

\footnotetext{
*This explanation is highly simplified, and one must recognize that many important factors are not fully understood. Some of the more inportant uncertainties are related to (a) thermal and adsorptive response of the oceans; (b) feedback effect on climate of changes in precipitation, evaporation, and cloud cover that result from a "first-round" warming; (c) exact behavior of clouds; (d) changes in the rate of photosynthesis in the surface mixed layer of the oceans; (e) effect of increased levels of $\mathrm{CO}_{2}$ on plant growth and thus on $\mathrm{CO}_{2}$ uptake by plants; (f) sulfur emissions and sulfur chemistry and their effect on cloud albedo (Penner, 1990); ( $\mathrm{g}$ ) rate of release of methane hydrates (solid, ice-like bindings of water and methanc) decomposed by a warmer climate; (h) net effect of land-use changes (primarily deforestation); (i) behavior of short-lived, indirect greenhouse gases, such as nitrogen oxides $\left(\mathrm{NO}_{\mathrm{x}}\right)$ (Penner, 199()); (j) lag between an increase in greenhouse gases and the stendy-state climatic response; ( $k$ ) local changes in weather; and (I) nature of long-term climate change independent of the effects of human activity. Clouds in particular are only crudely modeled (Kerr, 1989), and the oceans are not modeled much better. To complicate the matter further, recent salcilite data show no warming trend over the last 10 years (Spencer and Christy, 199()).
} 
This report estimates the global-warming potential of emissions of $\mathrm{CO}_{2}, \mathrm{CH}_{4}$, $\mathrm{N}_{2} \mathrm{O}, \mathrm{CO}, \mathrm{NMOC}$, and $\mathrm{NO}_{x}$ that result from the use of transportation fuels and electricity. In particular, Apps. $\mathrm{M}$ and $\mathrm{N}$ discuss $\mathrm{CH}_{4}$ and $\mathrm{N}_{2} \mathrm{O}$ as greenhouse gases and give a detailed review of the current emissiors database. Appendix $\mathrm{Q}$ discusses how alternative fuels might affect global climate through the changes they could cause in the concentration of tropospheric ozone.

This report does not consider emissions of CFCs or water vapor. For one reason, automotive CFCs are already scheduled to be phased out; for another, CFC emissions are independent of the type of fuel used by the vehicle. It is worth noting, however, that current CFC emissions from vehicles are of the same order of magnitude as $\mathrm{CO}_{2}$ emissions from the tailpipe (see App. Q). Emissions of water vapor from the combustion of fossil fuels worldwide are negligible, accounting for only about $0.05 \%$ of the average amount of water in the atmosphe:e and representing only $0.0013 \%$ of current global evaporation (DeLuchi et al., A Comparatize Analysis of Fulur Transportation Fuels, 1987). Therefore, these emissions can presumably be ignored.

\subsection{PREVIOUS RESEARCH}

\subsubsection{Emissions from Use of Transportation Fuels}

Emissions of greenhouse gases from the use of alternative transportation fuels were first analyzed by White in 1980, when the price of oil had reached an all-time high, and synthetic fuels from coal, oil shale, and other sources were being evaluated as means to reduce U.S. dependence on foreign oil. White calculated $\mathrm{CO}_{2}$ emissions resulting from the production and use of NG, coal, gasoline from crude oil, gasoline and diesel from shale oil, methanol from coal and wood, and ethanol from corn, and from electric vehicles using oil- and coal-based power (White, 1980). He found that most alternative fuels would emit more $\mathrm{CO}_{2}$ than would gasoline.

This interest in emissions of greenhouse gases from transportation fuels was short-lived, because the price of oil, and with it, interest in alternative fuels, began to drop in 1981. However, scientists continued to study $\mathrm{CO}_{2}$ and climate throughout the early and mid-1980s (Marland, 1982; National Research Council [NRC], 1983; Seidel and Keyes, 1983 [an EPA study]; MacCracken and Luther, 1985 [a DOE study]; and Bolin et al., 1986 [the SCOPE study]).

About 1985, interest in alternative transportation fuels resurfaced; however, their use was now considered mainly as a way to improve air quality rather than reduce oil imports. Much of this renewed impetus came from California, where it had already been determined that the use of methanol from coal was a possible way to improve urban air quality (Acurex Corp., 1982). In 1987, the connection between alternative transportation fuels and the greenhouse effect was made again, in reports 
by DeLuchi et al. (Transportation Fuels and the Greenhouse: Effect, 1987), Mackenzie: (1987), and Gushee (1988). MacKenzie and Gushee estimated emissions of (' $\mathrm{O}_{2}$ from the use of methanol. DeLuchi et al. (ulculated tons of $\mathrm{CO}_{2}$-equivalent emisuions of $\mathrm{CO}_{2}, \mathrm{CH}_{4}$, and $\mathrm{N}_{2} \mathrm{O}$ generated per year. They found that as an emission source, methanol made from NG ranked about the same as petroleum fuels; compressced natural gas (CNG) and liquefied natural gas (ING) ranked somewhat better than petroleum fuels; electricity (for electric vehicles) from the current U.S. power mix (mix of electricity-generating sources used nationally by all consumers in 1985) ranked about the same as petroleum fuels; and methanol from coal, electricity from coal-fired power plants, and hydrogen from coal ranked a lot worse than petroleum fuels.

In 1989, the California Energy Commission published an analysis of greenhouse gas emissions from the production and use of gasoline, diesel fuel, methanol from coal and NG, and CNG (Unnasch et al., 1989). The reporl, which improves on some aspects of the earlier work by DeLuchi et al. (Transportation Fincls and the Greenhouse Effect, 1987), ranks methanol from NG slightly better, and (NG slightly worse, than did DeLuchi and his colleagues.

Recently, Okken (The Case for Alternative Transportation Fucls, 1990) published the results of an analysis of emissions of $\mathrm{CO}_{2}$ from the total fuel cycle for vehicles running on biomass-derived ethanol; biomass-derived, coal-derived, and NGderived methanol; CNG; gasoline; and hydrogen from nonfossil fuels; and for electric vehicles (EVs) using electricity generated in Europe. Unfortunately, details of his calculation are not yet available in English. Ho and Renner (1990) analyzed emissions of $\mathrm{CO}_{2}, \mathrm{CH}_{4}$, and $\mathrm{N}_{2} \mathrm{O}$ frcm the production and use of gasoline, diesel fuel, CNG from NG, LPG from NG, methanol from NG and coal, and ethancul from corn. They found that every option except ethanol from corn and methanol from coal could increase or decrease greenhouse gas emissions, depending on the assumptions used. The use of ethanol from corn and methanol from coal causes increases, regardless of the assumptions.

Two reports that analyzed the $\mathrm{CO}_{2}$ emissions resulting from the use of ethanol from corn came to sharply different conclusions. Marland and Turhollow, as reported by Segal (1989), found a net reduction in emissions from use of cthanol (compared with gasoline). However, Ho (1989), in questioning Marland and Turhollow's assumptions about the productivity of corn acreage, energy use by corn-to-ethanol plants, and by-producl credits, found a net increase. Marland and Turhollow responded to Ho's criticisms in an Oak Ridge National Laboralory report (Marland and Turhollow, 1990).

Ford produced its own analyses of emissions (Hammerle et al., 1988; Schwarz, An Industry Perspective of Transportation and Global Warming, 1990), as have other auto and oil companies (e.g., Amann, The Passenger Car and the Greenhowse Effect, 1990; Amann, Technical Options for Energy Conservation and Controlling Linvirommental Impact in Higliday Vehicles, 1990; Amann, Ho, and Renner, 1991). DOE issued a (raft 
analysis (Mueller, 1990) that reviews and compares previous studies and makes its own point estimates of relative emissions. Fisher (1991) also analyzed previous studies and the potential of alternative fuels to reduce emissions of greenhouse gas emissions. I published very preliminary results of the analysis presented here (see DeLuchi, 1990).

\subsubsection{Emissions from Use of Fuels to Generate Electricity}

Grubb (1989) used very rough estimates of $\mathrm{CO}_{2}$ emissions from upstream processes (feedstock recovery, transport, and processing) to calculate fuel-cycle emissions of $\mathrm{CO}_{2}$ from the use of coal, oil, and gas to generate electricity. A year later, Wilson (1990) performed a similar analysis, but he also included $\mathrm{CH}_{4}$ emissions and used slightly better estimates of emissions from upstream processes. Wilson's main objectives were to evaluate emissions from electricity-generating technologies and demonstrate a method of converting $\mathrm{CH}_{4}$ and $\mathrm{N}_{2} \mathrm{O}$ emissions into $\mathrm{CO}_{2}$-equivalents rather than to estimate energy use and emissions from upstream fuel production and distribution processes in detail. In The Case for Alternative Transportation Fucls in the Context of Greenhouse Gas Constraints, Okken (1990) refers to another report by himself (in Dutch) that calculates emissions of $\mathrm{CO}_{2}$ from the 1987 European electricity mix, but it is not clear if that report gives full fuel-cycle emissions or results by fuel type.

Three reports estimate, in retail, fuel-cycle emissions of $\mathrm{CO}_{2}$ for one electricity-generating fuel for one country. Kudama (1990) drafted a detailed analysis of $\mathrm{CO}_{2}$ emissions from the coal-to-electricity fuel cycle for Japan, which covers emissions from the mining, transport, handling, and combustion of coal and from ash transport. More recently, he analyzed emissions of $\mathrm{CO}_{2}$ and $\mathrm{CH}_{4}$ from the LNG-to-power cycle (Kudama, 1991). Mortimer (no date) conducted a detailed analysis of $\mathrm{CO}_{2}$ emissions from the nuclear-power cycle in Britain.

The reports by Mortimer (no date) and Kudama (1990, 1991) are detailed. However, they cover only one fuel and only one greenhouse gas -- $\mathrm{CO}_{2}$ (except Kudama's LNG report includes $\mathrm{CH}_{4}$ ). To date, there is no single study that evaluates, in detail, emissions of all greenhouse gases, from all stages of the fuel production and use cycle, for all fuels and electricity-generating technologies.

\subsection{NEED FOR MORE RESEARCH}

Although research on energy use and the greenhouse effect is becoming more sophisticated, important disagreements romain. For example, it is not clear if vehicles powered by methanol, NG, ethanol, or electricity are better or worse than gasoline or diesel vehicles. Neither is it clear under what conditions NG-based electricity generation is worse than coal-based generation. Some of the disagreements result from the different assumptions about key variables, and some 
result from different methods and different levels of detail used in the analyses. A comprehensive and detailed analysis could resolve many of these disagreements or at least narrow the gaps between them.

The research to date can be built and improved upon in several ways. Some of the important tasks to be conducted are as follows:

- Make original and detailed calculations of the amount and type of energy required at each stage of all the fuel production and use cycles. (The report by Mueller, 1990, goes into some detail, with relatively recent data, for the petroleum cycle.)

- Fully account for "own-use" of energy in each fuel cycle (e.g., the use of coal-derived electricity at coal mines).

- Target the analysis for a future date, when alternative-energy technologies will be more fully developed and more widely used.

- Make complete carhon-balance calculations.

- Analyze precisely the chemical composition of gasoline, NG, and coal.

- Build detailed estimates of emissions from power plants and other combustion sources.

- Estimate the actual mix of fuels used to generate electricity for major electricity-consuming processes used in the transportation fuel cycles (such as petroleum refining).

- Calculate emissions from the nuclear-fuel cycle.

- Calculate emissions from the use of biomass to generate electricity.

- Calculate emissions from the use of advanced electricity-generating technologies, such as fuel cells.

- Perform a comprehensive review of the literature on the energy requirements of petroleum refineries, coal-to-methanol plants, NGto-methanol plants, and corn-to-ethanol plants.

- Analyze in detail the energy required to make future reformulated gasoline and low-sulfur diesel fuel. 
- Estimate in detail the $\mathrm{CH}_{4}$ emissions that come from coal mines and NG production and delivery systems and the greenhouse gas emissions that come from the venting and flaring of associated gas.

- Estimate the greenhouse gas emissions that come from the manufacture of the materials for vehicles and the assembly of vehicles.

- Estimate the greenhouse gas emissions that come from the manufacture of materials used to make power plants, tankers, and other major energy-processing and transport facilities and equipment.

- Include LPG as a fuel. (The Mueller, 1990, report includes LPG.)

- Include woody biomass as a feedstock for alcohols or SNG. (Okken, The Case for Alternative Transportation Fuels in the Context of Greenhouse Gas Constraints, 1990, has reported results for methanol from wood; details are not yet available in English.)

- Consider electric, hydrogen, and fuel-cell vehicles in detail. (DeLuchi et al., Transportation Fuels and the Greenhouse Effect, 1987, has some preliminary calculations.)

- Analyze in detail the thermal efficiency and weight of alternativefuel vehicles relative to petroleum-fuel vehicles.

- Summarize and analyze all the existing data on $\mathrm{CH}_{4}$ and $\mathrm{N}_{2} \mathrm{O}$ emissions from vehicles and power plants. (DeLuchi et al., Transportation Fuels and the Greenhouse Effect, 1987, has a partial review.)

- Include emissions of indirect greenhouse gases, CO, NMOC, and $\mathrm{NO}_{\mathrm{x}}$ from all combustion sources.

- Correctly convert emissions of non- $\mathrm{CO}_{2}$ gases to the temperatureequivalent amount of $\mathrm{CO}_{2}$ (following the precedent set by Shine et al., 1990; Lashof and Ahuja, 1990; and others).

- Model the combined, overall effect of using alternative fuels in both heavy-duty and light-duty applications.

- Account for uncertainty by providing a wide range of scenario analyses (rather than just high and low estimates).

Most of these major tasks could be broken down into many subtasks. 
In summary, no study to date analyzes all fuels, all steps of the fuel and vehicle production and use cycle, or all greenhouse gas emissions, for either transportation or electricity-generating fuels. This report is an attempt in this direction. 


\section{ANALYSIS OF GREENHOUSE GAS EMISSIONS FROM ELECTRICITY AND TRANSPORTATION FUEL CYCLES}

\subsection{FUEL-CYCLE STAGES AND EMISSIONS STUDIED BY THE MODEL}

To obtain the results for the analysis discussed in this report, I used an energy and emissions model. It calculates the emissions of direct $\left(\mathrm{CO}_{2}, \mathrm{CH}_{4}\right.$, and $\left.\mathrm{N}_{2} \mathrm{O}\right)$ and indirect $\left(\mathrm{NO}_{\mathrm{x}}, \mathrm{CO}\right.$, and NMOCs) greenhouse gases that result from the electricity and transportation fuel cycles. A particular fuel cycle usually consists of several of the stages that are listed below:

- End use: When a finished fuel product, such as gasoline, is used by consumers.

- Compression or liquefaction: When gaseous transportation fuels are compressed or liquefied.

- Fuel distribution: When a finished fuel product is transported to end users; for example, when gasoline is shipped by truck to a service station.

- Fuel production: When a primary resource, such as crude oil or coal, is transformed into a finished fuel product or energy carrier, such as gasoline or electricity.

- Feedstock transport: When a primary resource is transported to a fuel production facility; for example, when crude oil is transported from the wellhead to a petroleum refinery.

- Feedstock recovery: When a primary resource, such as crude oil or coal, is extracted.

- Manufacturing for automotive industry: When the materials used in private motor vehicles are manufactured and the vehicles themselves are assembled.

- Support for transport: When building, servicing, and administrative support are provided for transport and distribution modes, such as large, crude-carrying tankers or unit coal trains.

- Manufacturing for energy utilities: When materials for major energy facilities, such as petroleum refineries, corn-to-ethanol plants, and coal-burning power plants, are manufactured. 
- Changes in land use: When changes in land use result from the development of a primary resource; for example, when rangeland is cleared to plant corn to make ethanol.

At each of these stages of a fuel cycle, greenhouse gases can be produced or emitted in several different ways:

- From the combustion of fuels that provide process energy (for example, the burning of bunker fuel in the bciler of a supertanker or the combustion of refinery gas in a petroleum refinery);

- From the evaporation or leakage of energy feedstocks and finished fuels (for example, the evaporation of NMOCs from gasoline storage terminals); or

- From the venting, leaking, or flaring of gas mixtures that contain greenhouse gases (for example, the venting of coal-bed gas from coal mines); or from themical transformations not associated with burning process fuels (for example, the curing of cement, which produces $\mathrm{CO}_{2}$; the denitrification of nitrogenous fertilizers, which produces $\mathrm{N}_{2} \mathrm{O}$; or the scrubbing of sulfur oxides from the flue gas of coal-fired power plants, which can produce $\mathrm{CO}_{2}$ ).

The method that is used in this analysis to model emissions from each stage of the fuel cycle is outlined in the following section and described in more detail in App. A. For a recent overview of the fuel-cycle evaluation method, see Ashton et al. (1990).

\subsection{SOURCES OF DATA AND METHODS USED BY THE MODEL TO ESTIMATE EMISSIONS, BY FUEL-CYCLE STAGE}

\subsubsection{End Use by Vehicles}

In general usage, end-use emissions refer to emissions of greenhouse gases that result from the combustion and evaporation of fueis at the point of final use by consumers. In this report, however, the term refers specifically to emissions that result from the use of fuels in motor vehicles, since the end use of electricity does not produce greenhouse gases. Motor venicles emit all the greenhouse gases considered in this analysis: $\mathrm{CO}_{2}, \mathrm{CH}_{4}, \mathrm{~N}_{2} \mathrm{O}, \mathrm{NO}_{x}, \mathrm{CO}$, and NMOCs.

The amount of $\mathrm{CO}_{2}$ emitted from a vehicle is a function of the vehicle's energy consumption rate (in $10^{6}$ Btu per mile), the carbon content of its fuel (grams per $10^{6} \mathrm{Btu}$ of fuel), and the fate of the carbon in the fuel (e.g., complete oxidation to $\mathrm{CO}_{2}$ or partial oxidation to $\mathrm{CO}$ or emission as $\mathrm{NMOC}$ or $\mathrm{CH}_{4}$; the carbon that ends 
up as $\mathrm{CH}_{4}, \mathrm{CO}$, and NMOC is counted separately from the carbon that ends up as $\mathrm{CO}_{2}$ ). The energy consumption rate of gasoline and diesel vehicles is calculated from the input fuel economy, which is 30 miles per gallon (mpg) for light-duty vehicles (LDVs) on reformulated gasoline in city/highway driving, and $6 \mathrm{mpg}$ for heavy-duty vehicles (HDVs) on diesel fuel in trucking applications. The energy consumption rate for alternativemfuel vehicles is calculated by adjusting the energy consumption rate of baseline petroleum-fuel vehicles for differences between alternative-fuel and baseline petroleum-fuel vehicles in engine thermal efficiency and in vehicle weight. The vehicle's relative weight is determined on the basis of the characteristics of the alternative-energy storage system (e.g., battery or CNG tank) and the vehicle's driving range (number of miles that the vehicle can travel from the time the fuel tank is full until it is empty; see Table 2).

Values for emissions of $\mathrm{CH}_{4}, \mathrm{~N}_{2} \mathrm{O}, \mathrm{NO}_{x}, \mathrm{CO}$, and NMOCs are input directly into the emissions model. The values for $\mathrm{CH}_{4}$ and $\mathrm{N}_{2} \mathrm{O}$ are based on my analysis of the existing database (documented in Apps. $\mathrm{M}$ and $\mathrm{N}$ ). The $\mathrm{NO}_{\mathrm{x}}, \mathrm{CO}$, and $\mathrm{NMOC}$ emission values are based on runs of MOBILE4, the EPA's emissions model. I have adjusted input parameters and results of the model to reflect the new Clean Air Act Amendments (see App. B).

\subsubsection{Fuel Compression or Liquefaction}

Hydrogen and NG must be compressed or liquefied to be stored compactly on board a vehicle. Compression or liquefaction requires energy and produces greenhouse gases. The amounts and types of energy used by compressors and liquefiers are shown in Tables 3 and 4. Emissions of greenhouse gases at this stage are calculated in the same manner as are emissions from fuel production, a procedure discussed in Sec. 3.2.4.

\subsubsection{Fuel Distribution}

Fuel is distributed from fuel production facilities (such as petroleum refineries) to end users (such as service stations) by train, truck, ship, and/or pipeline. These distribution (or transportation) modes consume energy and emit greenhouse gases. For example, marine tankers use residuai fuel \#6 (bunker fuel), trains and trucks use diesel fuel, most NG-pipeline compressors burn NG, and oilpipeline compressors use electricity-driven motors.

The emissions model first calculates the amount and kind of energy used by each distribution mode per unit of product (e.g., gasoline, electricity) made available to end users. In most cases, the amount and type of fuel used by each distribution mode is calculated as the amount of energy required to move one ton of transportation fuel a distance of one mile (i.e., Btu/ton-mi), multiplied by the number of tons of fuel actually moved and the number of miles traveled for an 


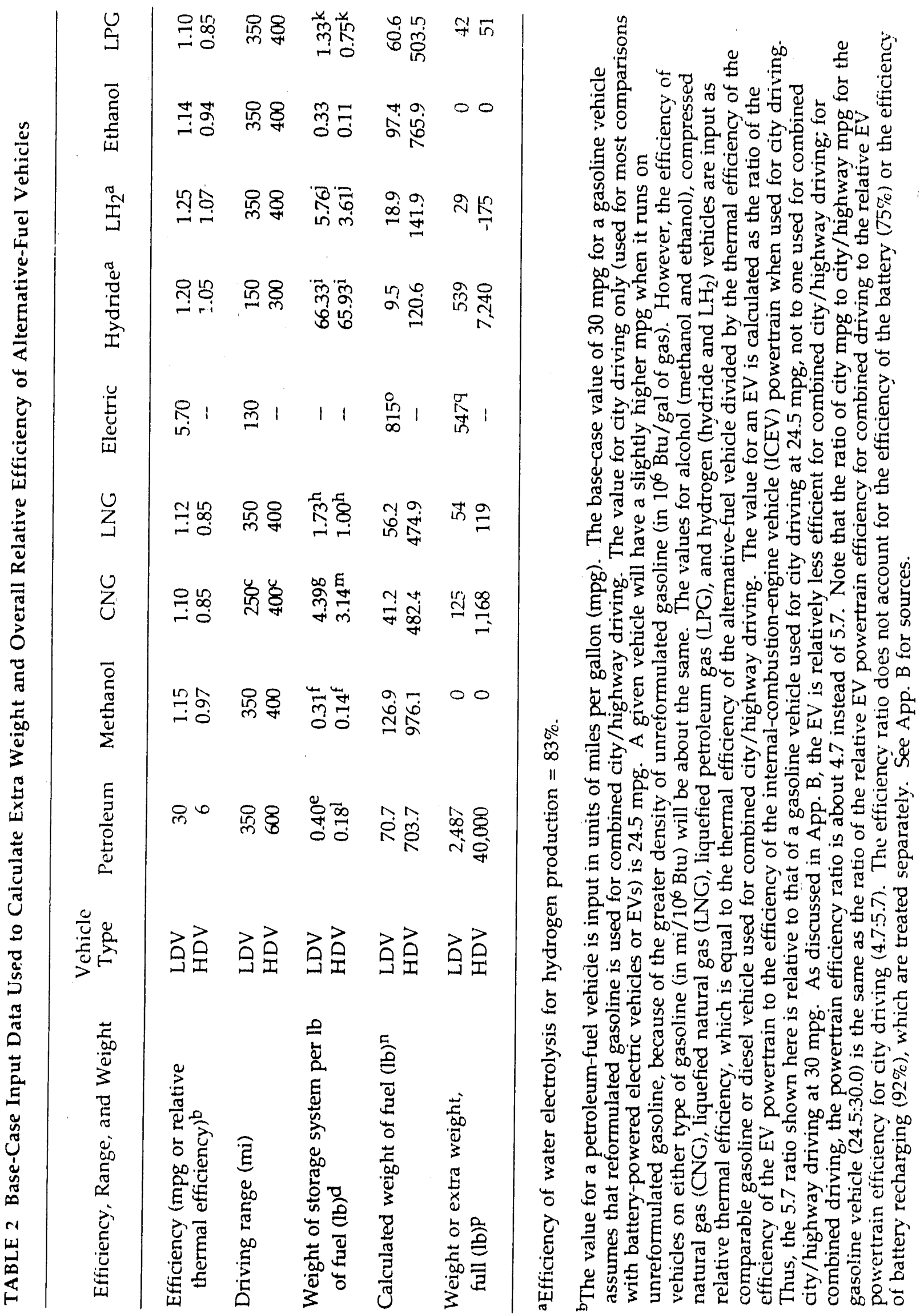




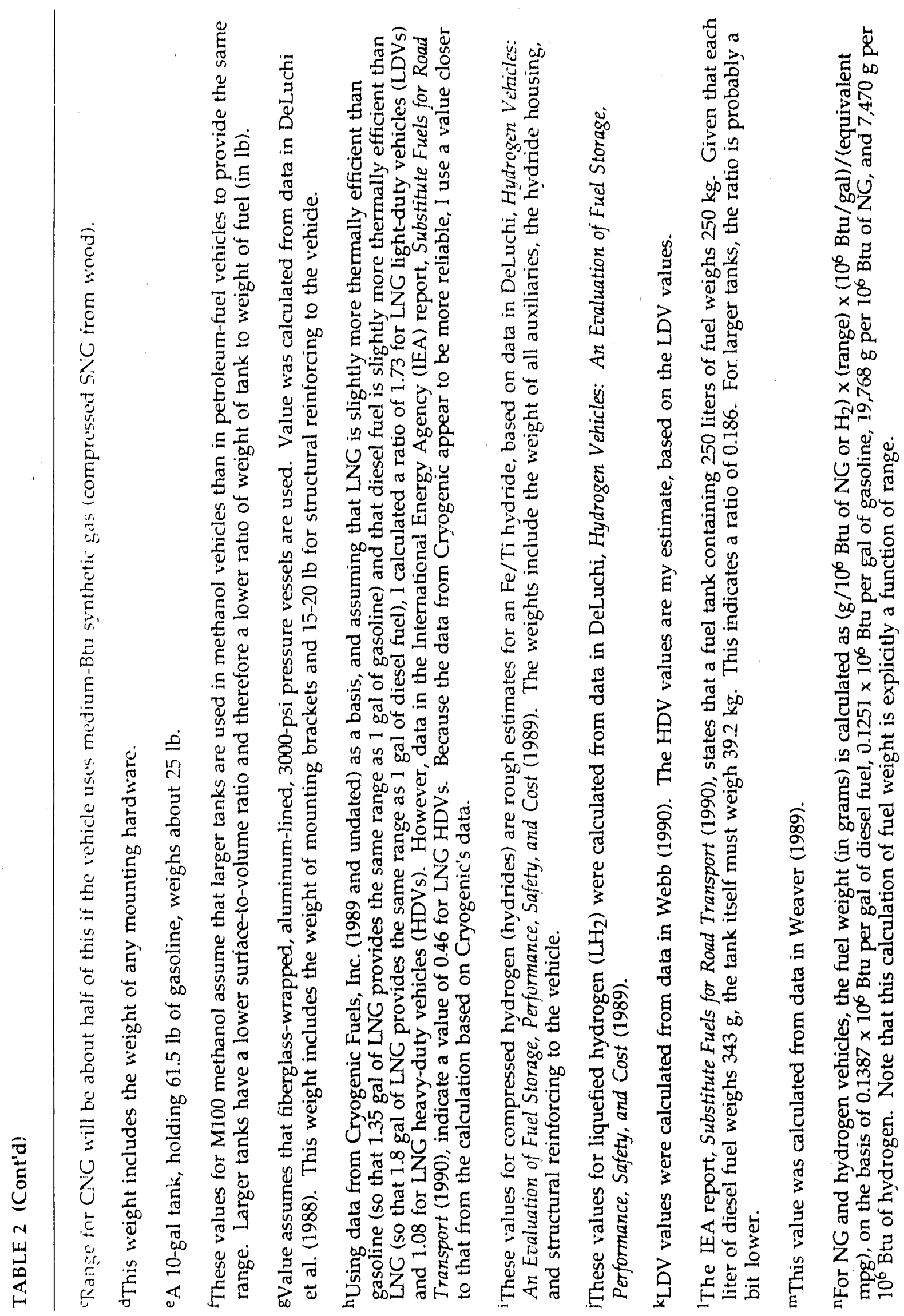




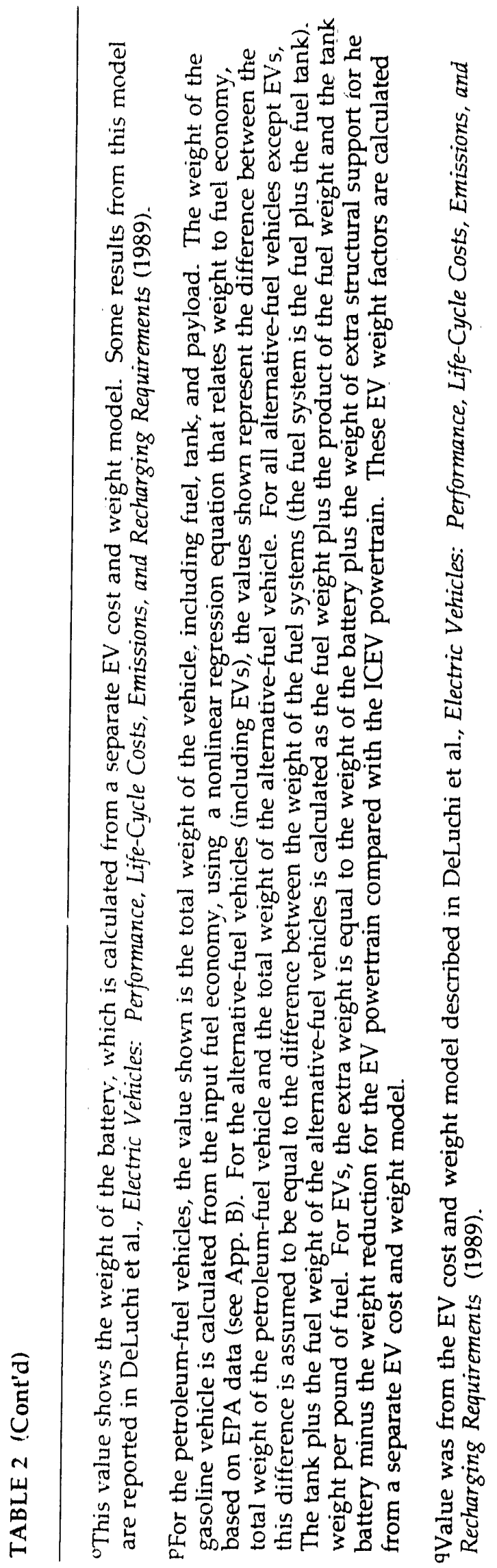




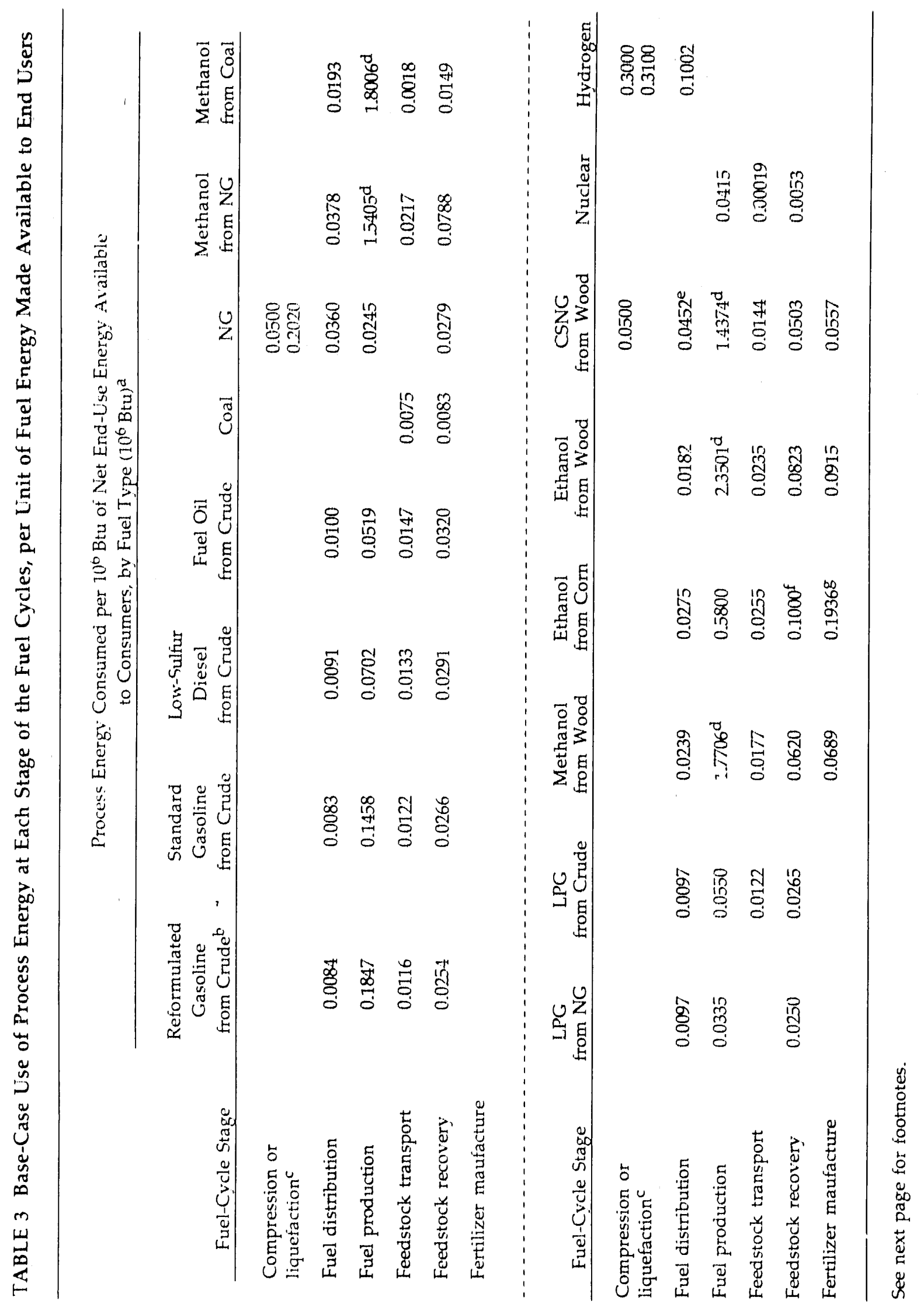




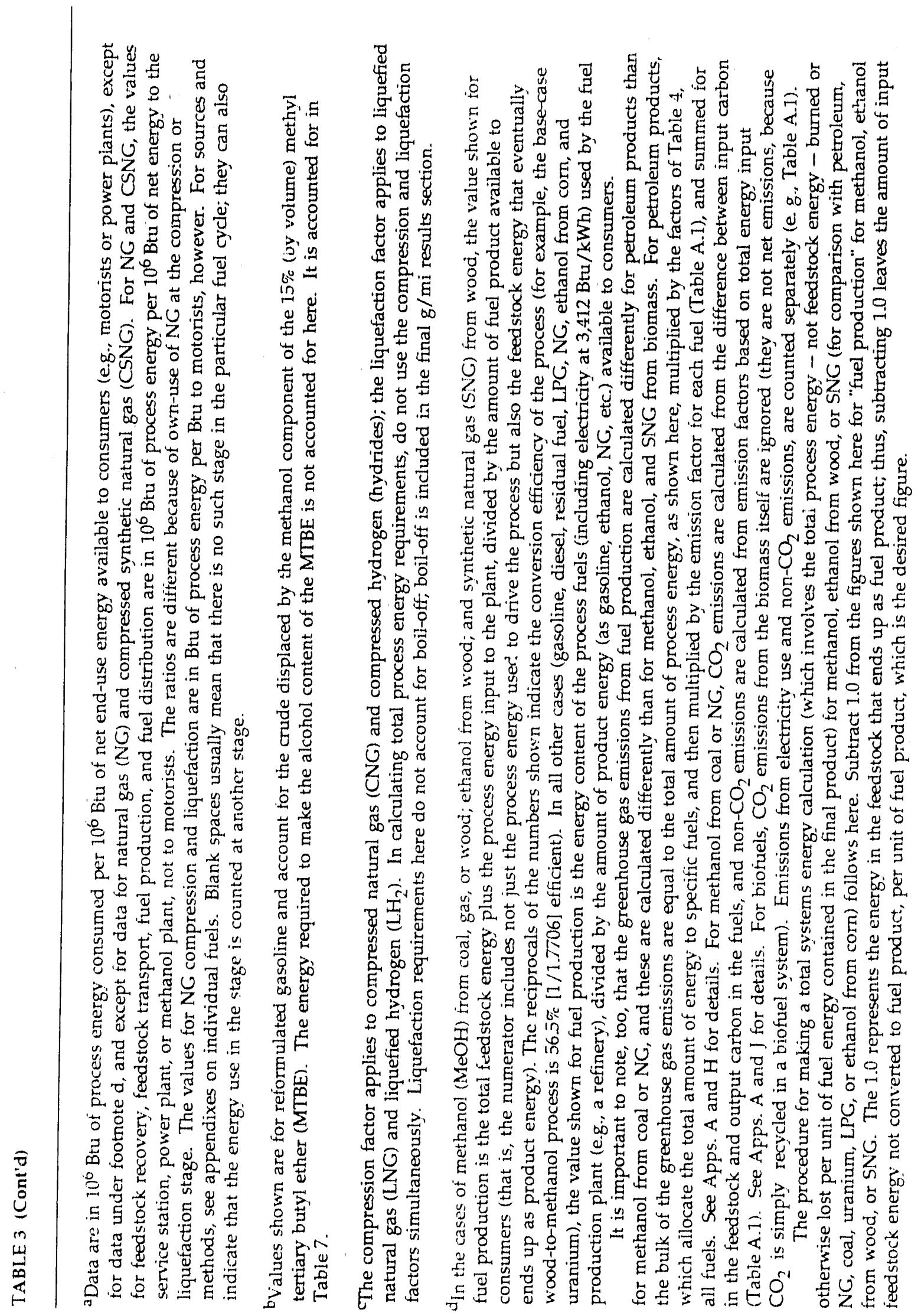




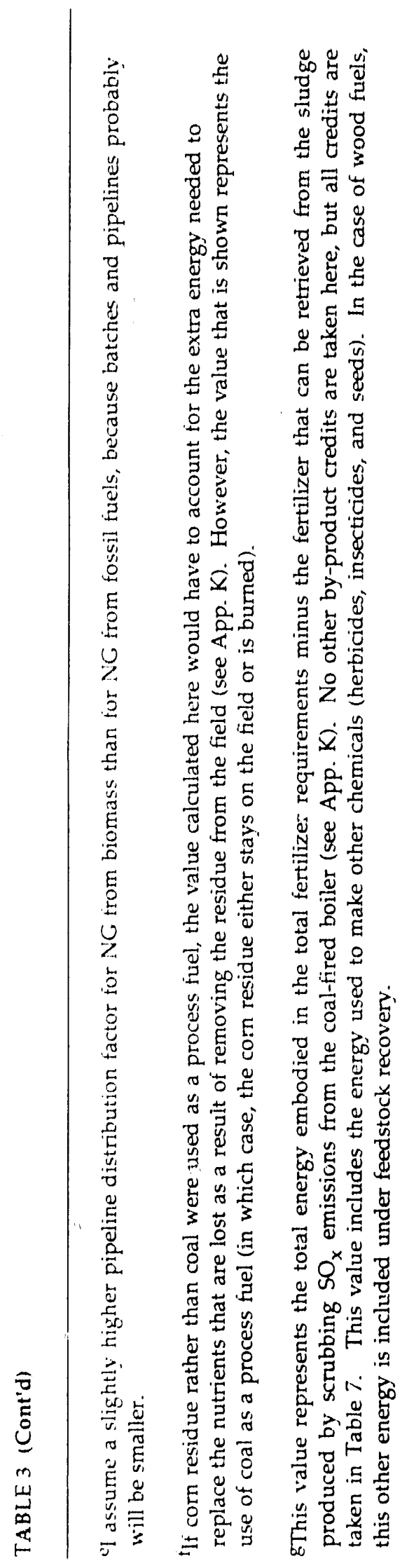




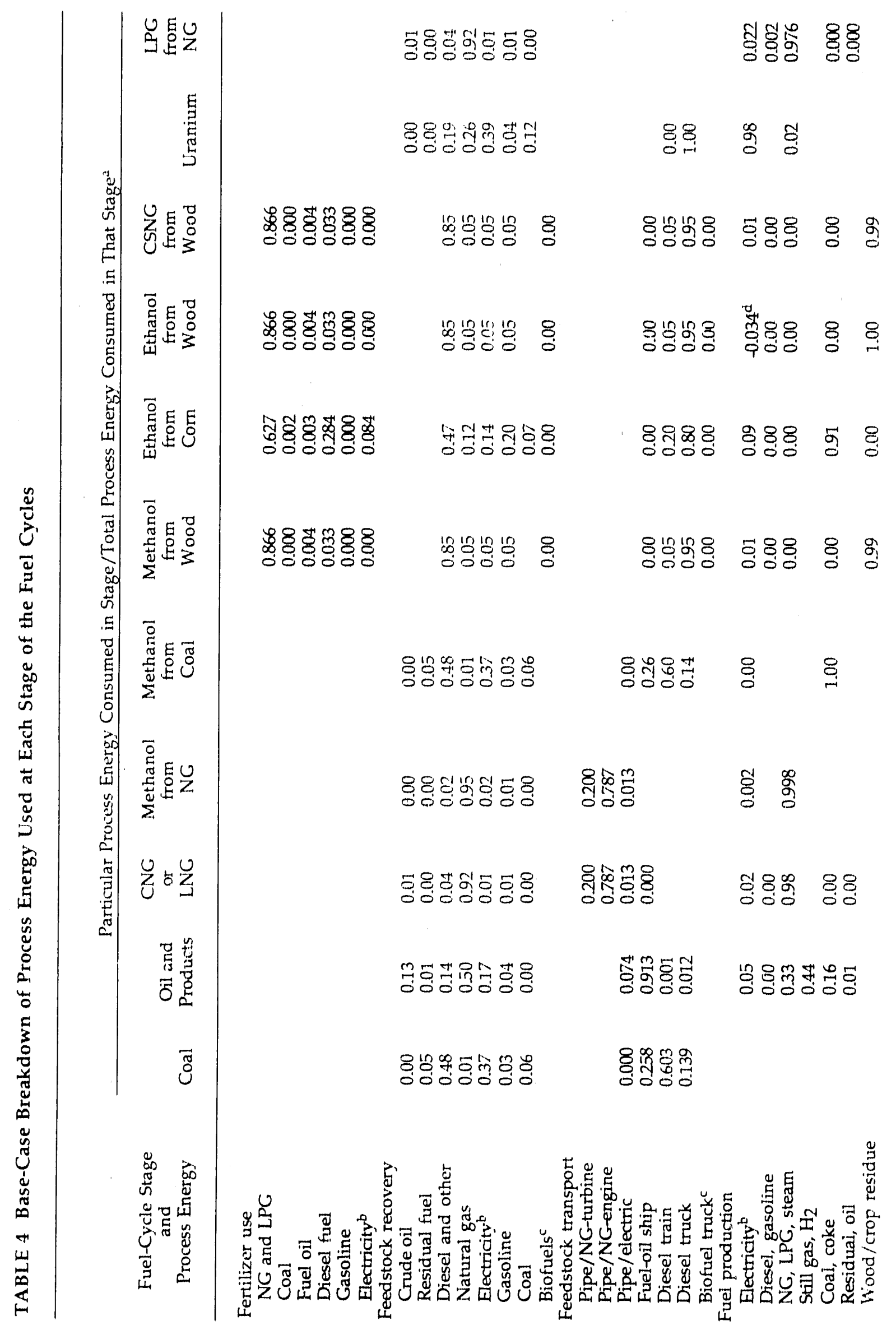




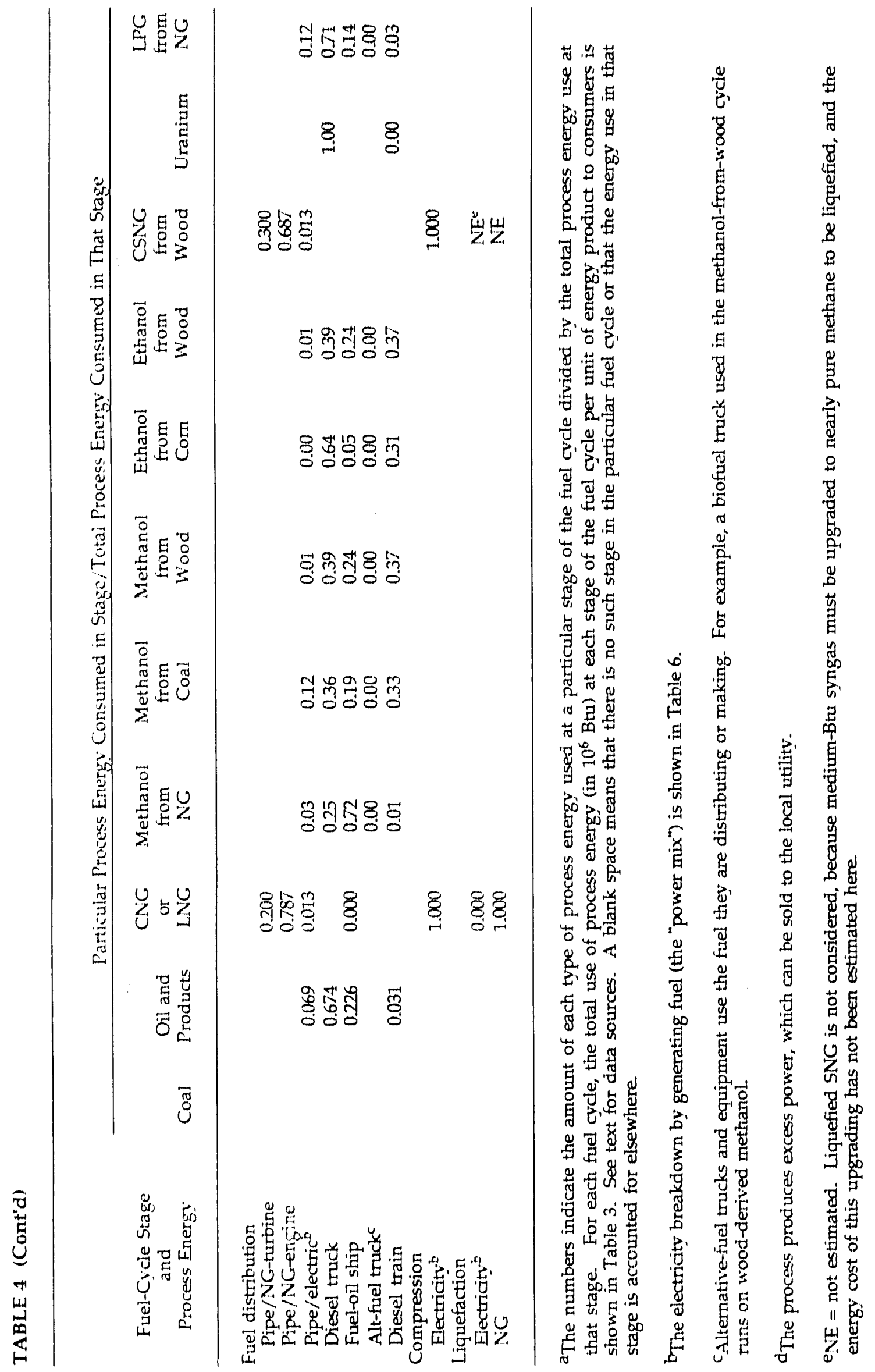


average haul. The estimates of the Btu/ton-mi "intensity" of a transportation mode are based on a detalled review of the literature (for example, see Rose, 1979). In the case of oil tankers, their weighted Btu/ton-mi intensity is calculated from data on the number of tankers in each of several tonnage classes and the energy intensity of lankers in each class. Data on tons moved and average haul lengths are analyzed and documented in the appendixes pertaining to individual fuels. Tables 3-5 show the amount of energy and the mode splits used to distribute fuels. See App. E for details.

The model then multiplies the energy-use factors for each mode (in Btu of process fuel per Btu of product made available to end users) by greenhouse-gas emission factors for each mode (in grams of $\mathrm{CO}_{2}$-equivalent emissions per Btu of process fuel consumed by the distribution mode; see Table A.1), to calculate total $\mathrm{CO}_{2}$-equivalent greenhouse-gas emissions per unit of product available to end users. The model also includes "second-order" emissions, which are emissions from the production and distribution of the process fuels used by the distribution modes.

The $\mathrm{CO}_{2}$-equivalent emission factor for each distribution mode is equal to the $\mathrm{CO}_{2}$ emission factor plus the $\mathrm{CO}_{2}$-equivalent of the $\mathrm{CH}_{4}, \mathrm{~N}_{2} \mathrm{O}, \mathrm{NO}, \mathrm{CO}$, and $\mathrm{NMOC}$ emission factors. $\mathrm{CO}_{2}$ emissions are calculated from the carbon content and energy density of the fuel, with a complete carbon accounting. Emissions of $\mathrm{CH}_{4}, \mathrm{~N}_{2} \mathrm{O}$, $\mathrm{NO}_{x}, \mathrm{CO}$, and NMOC.s from fuel distribution modes are input to the model directly. Most of the input values for emissions of $\mathrm{CH}_{4}, \mathrm{NO}_{\mathrm{x}}, \mathrm{CO}$, and NMOCs were taken from the EPA report, Compilation of Air Pollutant Emission Factors (1985, 1988), which is generally referred to as "AP-42" (see Table A.1). I assume that the number of grams of $\mathrm{N}_{2} \mathrm{O}$ that are emitted per Btu of fuel "F" used by distribution modes is the same as the number of grams of $\mathrm{N}_{2} \mathrm{O}$ that are emitted per Btu of fuel "F" used by power plants. (Appendix A provides a formal expression of these calculations.) Emissions from this stage also include NG from NG transmission and distribution. Data on leaks from NG production were taken from several recent estimates of actual gas leakage (as opposed to estimates of "unaccounted-for gas" in general) (Tiable 5; App. M).

\subsubsection{Fuel Production}

In this stage, greenhouse gases are emitted from petroleum refineries, ethanol fermentation facilities, wood gasification and synthesis plants, coal-to-methanol plants, NG-to-methariol plants, NG processing plants, uranium enrichment plants, power plants, and so on. These emissions are a function of the amount and type of process fuel used by the facility. Tables 3 and 4 show the base-case fuel-use data for all facilities except power plants. Table 6a shows the base-case energy efficiency for power plants, by type of fuel. Appendix D provides details on the efficiency and emissions of conventional and advanced electricity-generating technologies. 


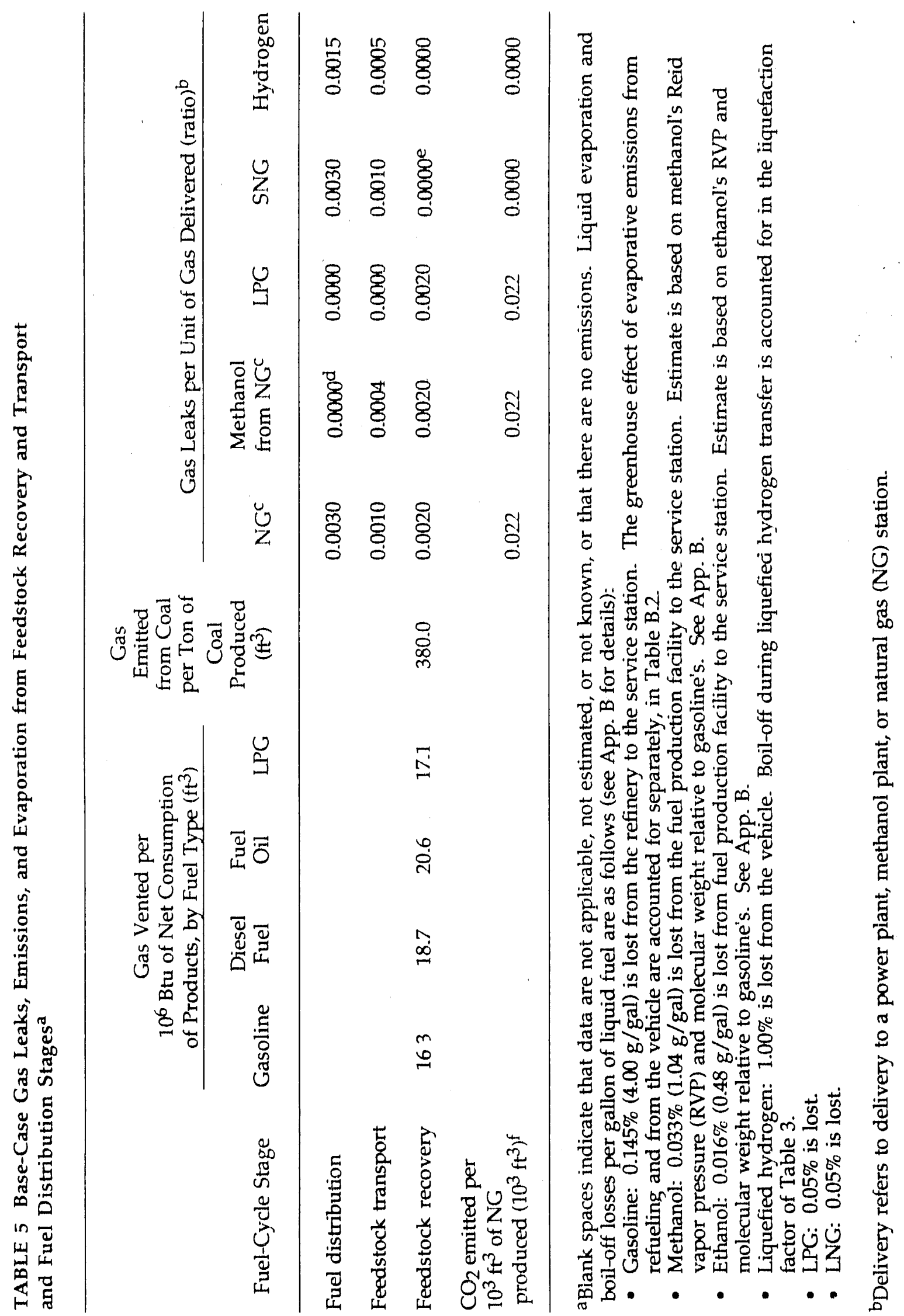




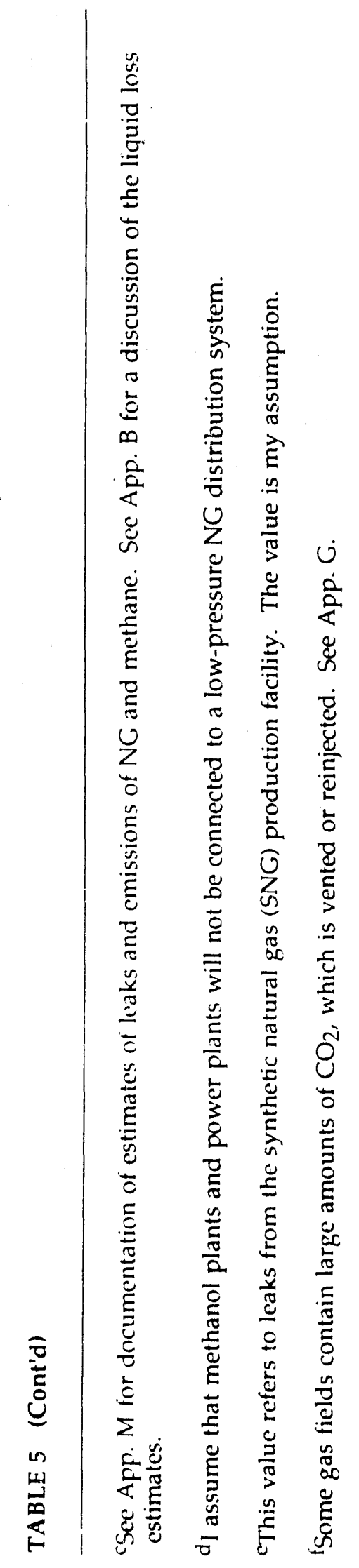


TABLE 6 Base-Case Breakdown of Electricity ("Mix of Power") Used by Major Processes in the Fuel Cycles

6a Efficiency of Electricity Generation, by Fuel Type

\begin{tabular}{lcccccc}
\hline Efficiency & $\begin{array}{c}\text { Coal } \\
\text { Boiler }\end{array}$ & $\begin{array}{c}\text { Oil } \\
\text { Boiler }\end{array}$ & $\begin{array}{c}\text { NG } \\
\text { Boiler }\end{array}$ & $\begin{array}{c}\text { NG } \\
\text { Turbine }\end{array}$ & $\begin{array}{c}\text { Methanol } \\
\text { Boiler }\end{array}$ & $\begin{array}{c}\text { Hydrogen } \\
\text { Turbine }\end{array}$ \\
\hline Efficiency & 0.329 & 0.318 & 0.328 & $0.330^{\mathrm{b}}$ & 0.330 & 0.450 \\
\hline
\end{tabular}

aData on the efficiency of coal, oil, and gas plants are from U.S. Department of Energy, Energy Information Administration projections of net efficiency (electricity energy leaving power plant/higher heating value [HHV] of fuel input) for the year 2000 in Annual Outlook for U.S. Electric Power 1990, Projections through 2010 (EIA, 1990). Estimates for methanol and hydrogen plants are my own.

${ }^{b}$ Assumes that $20 \%$ of turbines are combined cycles (45\% efficient) and that $80 \%$ are simple cycles (30\% efficient).

$6 \mathrm{~b}$ Source of Electricity, by Share

\begin{tabular}{|c|c|c|c|c|c|c|}
\hline Process & $\begin{array}{l}\text { Coal } \\
\text { Boiler }\end{array}$ & $\begin{array}{c}\text { Oil } \\
\text { Boiler }\end{array}$ & $\begin{array}{c}\text { NG } \\
\text { Boiler }^{\mathrm{a}}\end{array}$ & $\begin{array}{c}\text { NG } \\
\text { Turbine }^{a}\end{array}$ & Nuclear & Other ${ }^{b}$ \\
\hline Recharging $E \mathrm{~s}^{\mathrm{c}}$ & 0.500 & 0.150 & 0.225 & 0.075 & 0.020 & 0.030 \\
\hline Petrolcum refining/NGLs ${ }^{\mathrm{d}}$ & 0.310 & 0.050 & 0.245 & 0.082 & 0.227 & 0.087 \\
\hline Auto manufacture ${ }^{\mathrm{C}}$ & 0.528 & 0.058 & 0.049 & 0.016 & 0.251 & 0.097 \\
\hline Uranium enrichment ${ }^{f}$ & 0.878 & 0.004 & 0.001 & 0.000 & 0.084 & 0.033 \\
\hline Converting corn to ethanolg & 0.719 & 0.009 & 0.031 & 0.010 & 0.203 & 0.027 \\
\hline Compressing $\mathrm{NG}^{\mathrm{h}}$ & 0.523 & 0.052 & 0.131 & 0.044 & 0.165 & 0.086 \\
\hline Compressing or liquefying $\mathrm{H}_{2}{ }^{\mathrm{h}}$ & 0.523 & 0.052 & 0.131 & 0.044 & 0.165 & 0.086 \\
\hline Generic poweri & 0.523 & 0.052 & 0.131 & 0.044 & 0.165 & 0.086 \\
\hline
\end{tabular}

aThe breakdown between natural gas (NG) boilers and NG turbines for the year 2000 is based on projections in Annual Outlook for U.S. Electric Power 1989, Projections through 2010 (EIA, 1989) and the North American Electric. Reliability Council report, 1989 Electricity Supply and Demand (NERC, 1989), which indicate that about $25 \%$ of all gas-fired generation will come from combustion turbines or combined-cycle turbines.

bHydro, geothermal, wind, solar, and wood power.

"An estimate of the national "marginal" mix of power used specifically to recharge electric vehicles (EVs). See App. D for details.

dMix of power provided to petroleum refineries. See Apps. D and H. I assume that natural gas liquids (NGL) plants are located near petroleum refineries and so use the electricity mix used by refineries.

'Mix of power in states with auto-manufacturing facilities; see Apps D and P.

'Mix of power provided by utilities that supply the DOE enrichment facilities; see Apps. D and I. 
TABLE 6 (Cont'd)

gMix of power used by power plants in the corn-growing region. See Apps. D and K.

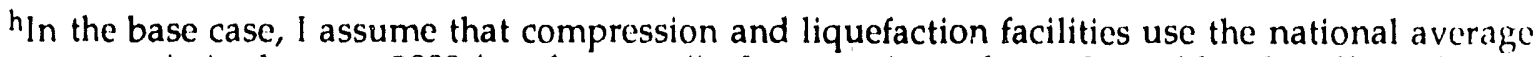
power mix in the year 2000 (see footnote $i$ ). In scenario analyses, I consider the effect of different power mixes.

iProjected national average electricity mix for the year 2000, taking into account the effect of the new Clean Air Act on fuel choice (ElA, Improving Technology, 1991; see App. D). The national average electricity mix is based on total electricity generation in the United States in the year 2000. This average or "generic" mix is used by oil pipelines, petroleum refineries, coal mines, oil wells, NG fields, NG pipelines, and methanol conversion plants, and for materials manufacture.

Data on fuel use by petroleum refineries were taken from detailed surveys by the EIA's Petroleum Supply Annual (various years). I allocate total energy use by refineries to the production of gasoline, diesel fuel, residual fuel, and LPG (App. H). Data on energy use by methanol production facilities are based on a review of many engineering studies (see App. J). Data for the biofuel cycles are based on a review of the literature (App. K). Base-case data on emissions from uranium conversion and enrichment are based on a detailed analysis of the uranium-to-electricity fuel cycle (App. I). For the base case, I assume that uranium is enriched using current U.S. gaseous-diffusion technology. Advanced enrichment technologies are considered in the scenario analyses.

In all cases, $\mathrm{CO}_{2}$ emission estimates are calculated as they are for distribution modes and vehicles, by using a complete carbon tracking. The $\mathrm{CO}_{2}$ emissions from the conversion of coal and NG to methanol are calculated by subtracting the carbon in a unit of methanol product from the total carbon in the amount of feedstock gas or coal required to produce the unit of methanol. Estimates of emissions of non$\mathrm{CO}_{2}$ greenhouse gases from fuel production facilities were taken from the EPA and other sources (see Table A.I and pertinent appendixes). For electricity generation, I use the recent revisions of estimates of $\mathrm{N}_{2} \mathrm{O}$ emissions (for example, see Ryan and Srivastava, 1989) (Apps. D and N).

\subsubsection{Feedstock Transportation}

Emissions from this stage include those resulting from the use of fuel by the transport modes that move feedstocks from the site of extraction to fuel production facilities. The modes are the same as those that distribute finished fuels. See Sec. 3.2.3 (Fuel Distribution) for an explanation of the method, Tables 3 and 4 for the base-case energy-use data, and App. A, Table A.1, for emission factors. 


\subsubsection{Feedstock Recovery}

Emissions from this stage include those resulting from the use of process fuel at coal mines, oil- and gas-producing facilities, uranium mines, corn and tree farms, and fertilizer-manufacturing facilities. Data on the amounts and types of energy used by fossil fuel and uranium recovery facilities were taken from surveys administered by the U.S. Bureau of the Census (for example, 1987 Census of Mineral Industries, Subject Series, Fuels and Electric Energy Consumed, 1990). Data on energy use in wood production were taken from sources in the technical literature (App. K). To obtain data on ethanol from corn, I analyzed in detail the energy required to grow and harvest corn, the amount of energy embodied in fertilizers, and $\mathrm{N}_{2} \mathrm{O}$ emissions from denitrification of fertilizer (App. K). Tables 3 and 4 present the base-case energy-use data for all fuels and feedstocks.

$\mathrm{CO}_{2}$-equivalent emission factors for the equipment used in feedstock recovery (scrapers, well-drilling equipment, trucks, tractors, etc.) are shown in Table A.1. Emissions of $\mathrm{CO}_{2}$ and $\mathrm{CO}_{2}$-equivalent emissions of $\mathrm{CO}, \mathrm{NO} \mathrm{C}_{x}, \mathrm{CH}_{4}$, $\mathrm{NMOCs}$, and $\mathrm{N}_{2} \mathrm{O}$ are calculated as they are in the stages described above.

This stage also includes emissions of $\mathrm{CH}_{4}$ from coal mines, emissions of $\mathrm{NG}$ from venting and flaring of associated gas, and emissions of NG from NG recovery operations. Methane emissions from coal mines are calculated from data from the U.S. Bureau of Mines (Deul and Kim, 1988) and other sources. Emissions from flaring of associated NG are calculated country by country from data in the EIA's International Energy Annual. Data on leaks from NG production were taken from several recent estimates of actual gas leakage (as opposed to estimates of unaccounted-for gas in general). Table 5 shows the base-case input data. For details, see the pertinent appendixes for data on particular fuels and App. M for data on $\mathrm{CH}_{4}$.

\subsubsection{Manufacture and Assembly}

The manufacture and assembly of materials for velicles, facilities, and equipment -- passenger cars, heavy-duty trucks, power plants, pipelines, tractors, well-drilling equipment, and so on -- are operations that are inherent in every fuel cycle. The use of energy to manufacture and assemble materials produces greenhouse gases. Different fuel cycles involve different amounts and types of materials and thus generate different amounts of greenhouse gases.

The amount of emissions resulting from the manufacture and assembly of materials used in motor vehicles is surprisingly large, on the order of $10-15 \%$ of the emissions resulting from the whole gasoline production and use cycle. Even more important are the differcnces in these emissions among the alternative vehicles (for example, the extra emissions that are generated from manufacturing the material used to make CNG tanks); they can amount 10 more than $2 \%$ of the emissions from 
the fuel production and use cycle. The base-case results of this analysis include estimates of emissions resulting from the manufacture and assembly of materials for motor vehicles. These emissions are calculated from data on the composition of gasoline vehicles, the composition of storage systems for alternative fuels, the amount of energy required to make a pound of each type of material, and the amount of emissions resulting from the use of energy to make the materials (App. P).

The base-case results also include estimates of emissions resulting from the use of energy to build, service, repair, and administer fuel distribution modes: ships, trucks, pipelines, and trains (Rose, 1979). However, the base-case results do not include emissions resulting from the use of energy to make the major materials for large facilities (like power plants, petroleum refineries, or coal mines) or feedstock-recovery equipment (tractors, chipper, scrapers, and so on). In App. P, I calculate that the amount of energy embodied in most facilities and equipment is very small when compared with the amount of energy the facilities and equipment actually process, carry, or produce; thus, it can be ignored. However, the biofuel cycles may be an exception (App. P). In some of the scenario analyses for biofuels, I include estimates of emissions from the use of energy to make materials for biomass recovery equipment and fuel production facilities. I ignore any energy embodied in any chemicals used throughout the fuel cycle, because in most cases, this is likely to be quite small.

\subsection{PARAMETERS ANALYZED AND ESTIMATED BY THE MODEL}

\subsubsection{Closed Fuel Cycles}

This analysis is "closed." In other words, the fuel cycles modeled in this analysis are, for the most part, complete (i.e., closed). For example, the final estimates include emissions from the use of energy to recover, process, and transport the fuel used to recover and transport the primary feedstock that ultimately ends up as the finished fuel used by consumer.

For each fuel -- coal, oil, NG, uranium -- the model calculates the amount of greenhouse gas emissions that result from making one energy unit of the fuel available to end users (Table 7). First, the model calculates the amount of electricity, coal, etc. that is required to bring an energy unit of fuel (for example, residual fuel oil) to the consumer (Tables 3 and 4). It then multiplies each of these energy-use factors by the appropriate emission factors (for example, grams of $\mathrm{CO}_{2}$-equivalent emissions per $10^{6} \mathrm{Btu}$ of $\mathrm{NG}$ used as a process fuel) to arrive at the amount of $\mathrm{CO}_{2}-$ equivalent emissions per energy unit of delivered fuel. The g/106 Btu emission factor for NG (used in the calculation of the $\mathrm{g} / 10^{6} \mathrm{Btu}$ emission factor for residual fuel oil) is calculated in the same way that the $\mathrm{g} / 10^{6} \mathrm{Btu}$ emission factor for residual fuel is calculated. Moreover, the calculation of the $\mathrm{g} / 10^{6}$ Btu factor for NG will at 


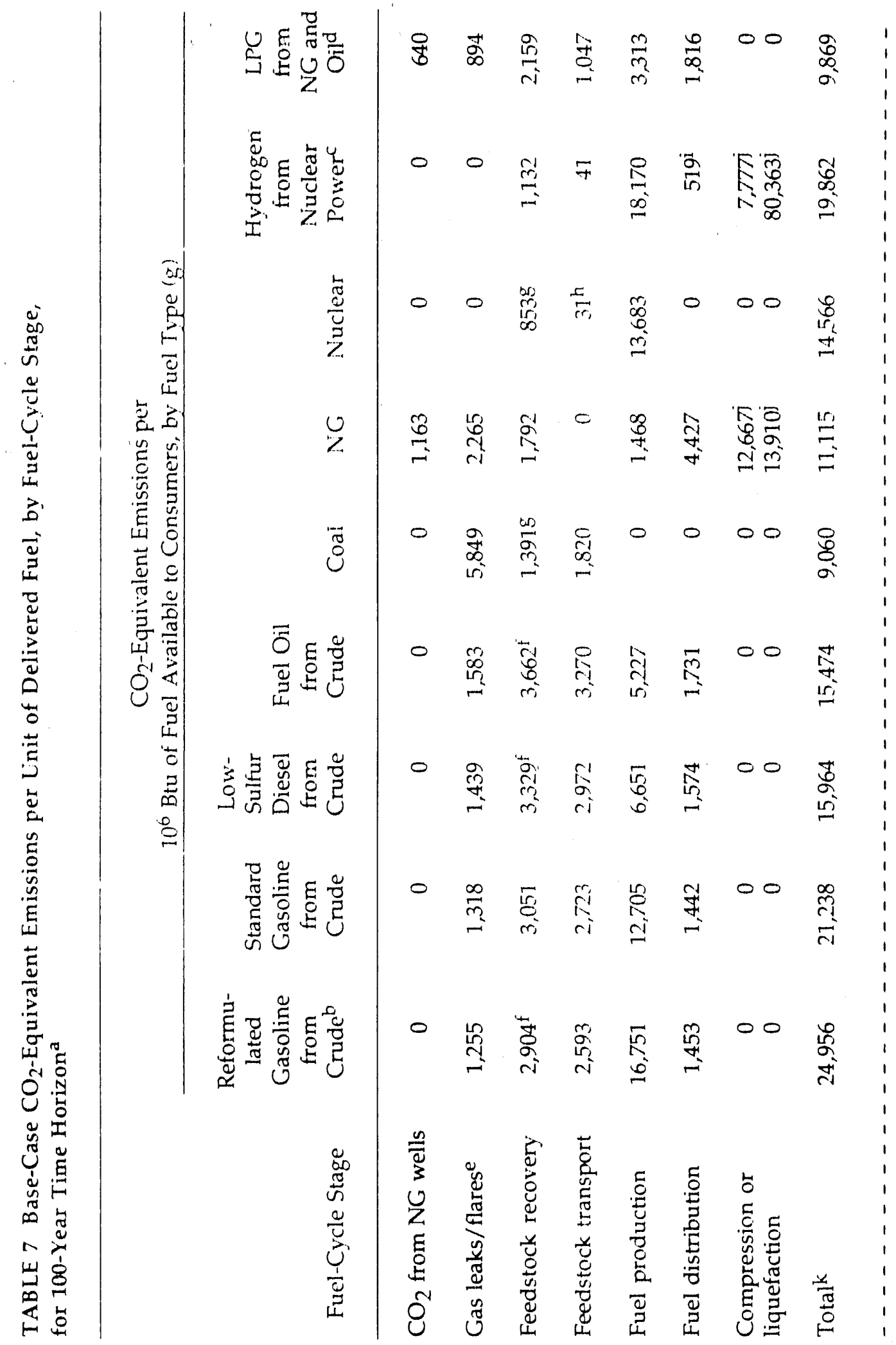




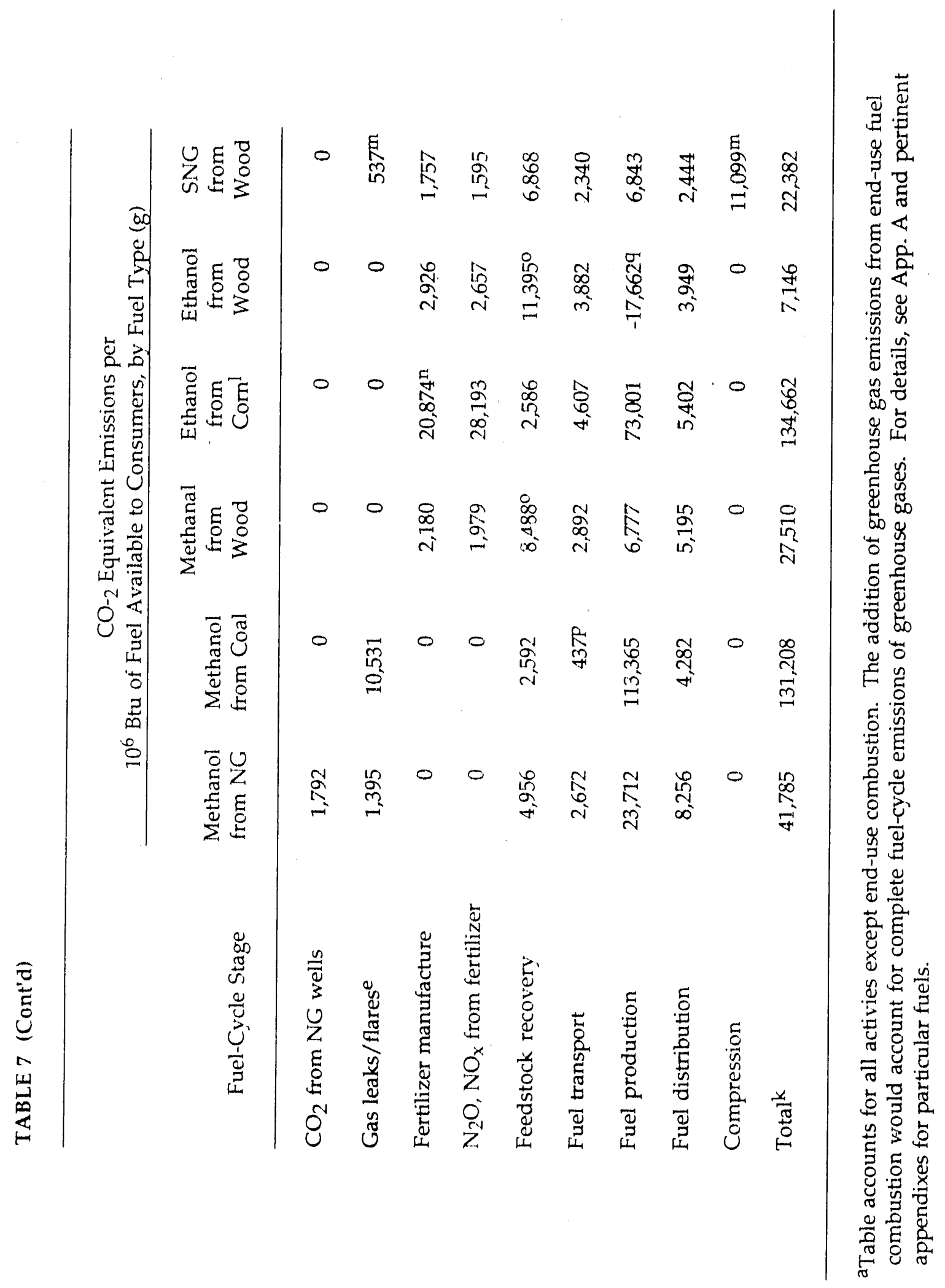




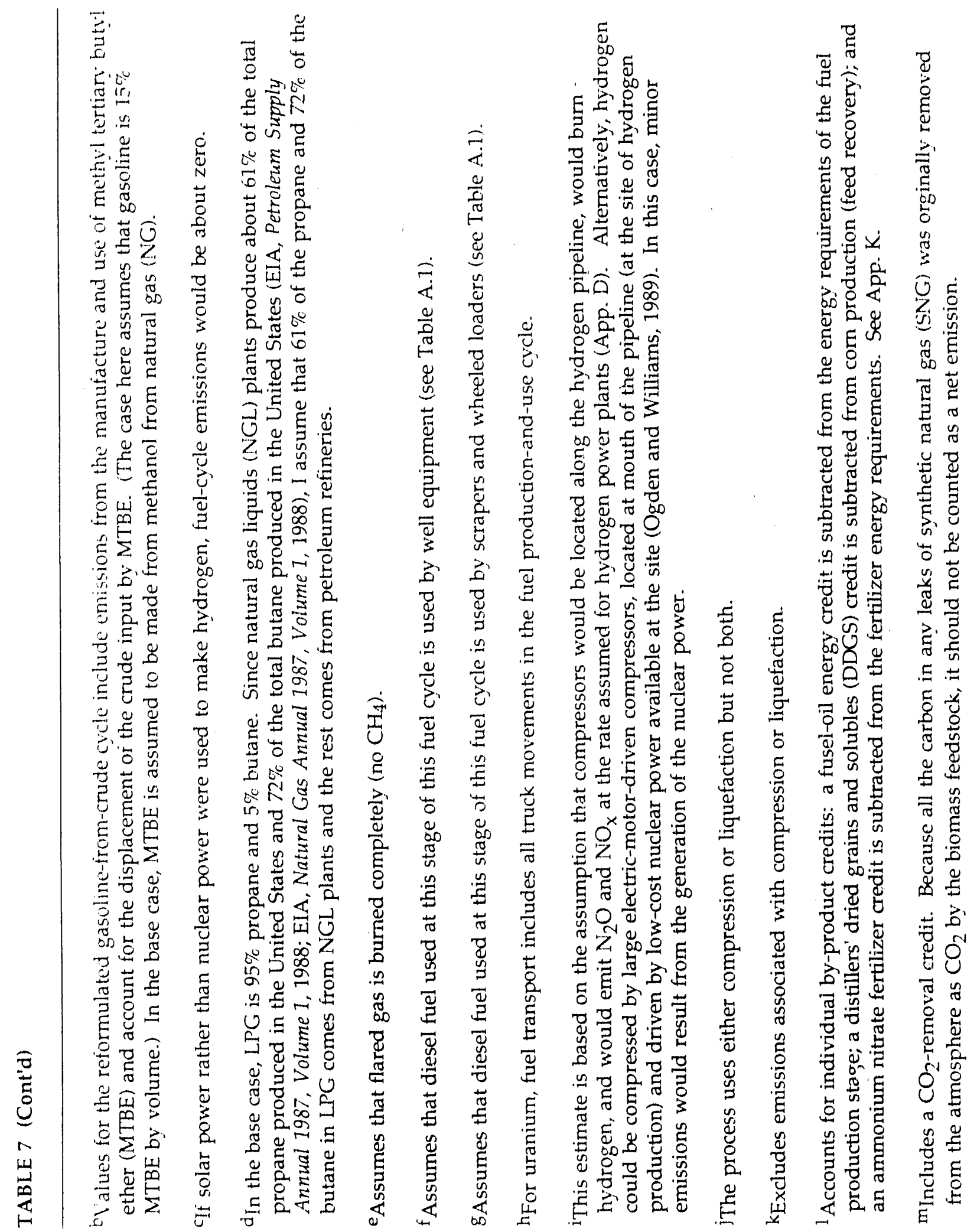




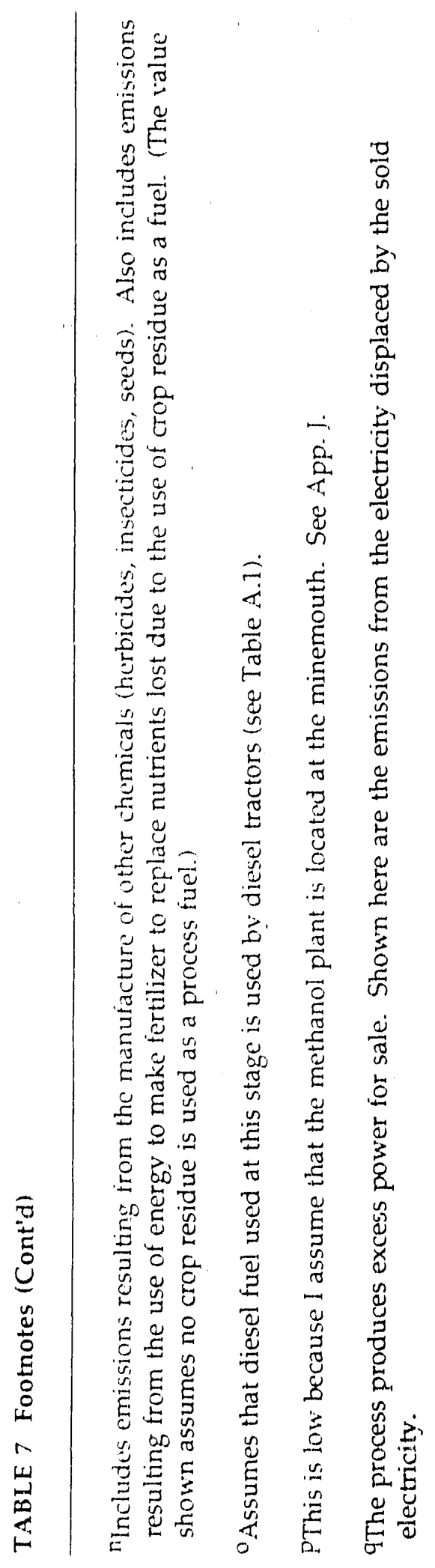


some point involve the $\mathrm{g} / 10^{6} \mathrm{Btu}$ factor for residual fuel oil. Thus, each $\mathrm{g} / 1 \mathrm{1}\left(\mathrm{f}^{\mathrm{G}} \mathrm{Btu}\right.$ emission factor relies on every other factor. This circularity, which is handled in the model by iterative calculations, makes the fuel-cycle emission factors complete.

The calculation procedure is delineated formally in App. A. Table 7 shows how many grams of $\mathrm{CO}_{2}$-equivalent emissions are generated per each $10^{6} \mathrm{Btu}$ of fuel that is delivered to end users for every fuel cycle analyzed here. These emission factors are useful in themselves; for example, one can use the $\mathrm{g} / 10^{6} \mathrm{Btu}$ emission factor for $N G$ to estimate greenhouse gas emissions from the delivery of $N G ;$ to residences for heating and cooking.

\subsubsection{Net Energy Available to End Users}

As noted above, a primary outpul of this model is an estimate of greenhouse gas emissions from each stage of the fuel cycle per unit of fuel energy made available to end users (Table 7). End users are defined here to be users of energy who are not involved in any of the upstream parts of the fuel cycle (fuel distribution, fuel production, feedstock transport, feedstock recovery, and materials manufacture and assembly). The purpose of an energy production and delivery system is to produce more than enough energy to keep itself running; if it produced only enough energy to keep itself running, it would be pointless as an energy production and delivery system. This means that "internal" energy use, or "own use" (e.g., the diesel fuel used by trucks that deliver diesel fuel, the petroleum fuels used at petroleum refineries, the nuclear electricity used to enrich the uranium needed for nuclear power plants, the NG used to generate the electricity required to compress $N G$, or the coal used to provide the power needed to generate the electricity used at coal

mining plants), should not be counted as end-use consumption. In this model, therefore, own use is deducted from the total amount of fuel produced to arrive at the net consumption available to end users.

\subsubsection{Fate of All Carbon}

The model accounts for the fate of all carbon, in detail. First, the carbon contained in $\mathrm{CO}, \mathrm{CH}_{4}$, and NMOC emissions is deducted from all available carbon in the fuel; then remaining carbon is assumed to be oxidized to $\mathrm{CO}_{2}$. In the case of vehicles, the carbon balance includes $\mathrm{CO}_{2}$ emissions from the combustion of engine oil.

\subsubsection{Gas and Coal Compositions}

The compositions of gasoline, gaseous fuels, and coal are analyzed in detail. Iimissions of $\mathrm{CO}_{2}$ resulting from the combustion of a fossil fuel are a function of the carbon content and enorgy density of the fuel. Because different analysts have 
assumed different values for carbon content and energy density, estimates of lotial fuel-cycle emissions have been quite different as well. This study trices to ellmilnale this uncertainty through a detalled analysis of the composiltons ard energy contents of petroleum products, gaseous fuels, and coal. Petroleum products are analy'nd as a specific mixture of aromatics, paraffics, olefins, and oxygenales. Refinery gon, $\mathrm{NG}$, and LPG are analyzed as a specific mixture of $\mathrm{CH}_{4}$, ethane, propane, butane, and other compounds. The average composition of coal is dertved from several recent coal databases. See App. C for details.

\subsubsection{Emissions from Distribution Stage}

Emissions from the distribution of fuels and feedstocks are analyzed in detail. At the heart of this calculation are three sets of data: (1) the energy intensity of trains, trucks, pipelines, and tankers, expressed in Btu/ton-mi; (2) the average distance that fuels and feedstocks are shipped by each of these modes; and (3) the amount of fuels or feedstocks shipped. These data are based on a detailed roview of the literalurc. See App. E and the appendix associated with the fuel of interest for details. This report also presents original analyses of the energy intensity of feedstock rocovery that are based on survey data of the U.S. Bureau of the Census (for example, 1987 Consus of Mineral Industries, Subject Serics, Fucls and Electric Energy Consumed, 199()).

\subsubsection{Target Year of 2000}

In this analysis, energy use and emissions are projected for the year 20(0)(). The new Clean Air Act Amendments will affect the emission rates of power plants and motor vehicles, the composition of gasoline, and the choice and quality of fucls used by power plants. These effects are taken into account in the projections of emissions. Emissions from motor vehicles are projected by adjusting MOBILEA, the EI'A's computer emissions model, to account for the new requirements under the new Clean Air Act Amendments.

Several other important paramelers are explicitly projected for the year 20000. The energy intensity of rall and truck transport is projected to improve somewhat by the year 2000 (EIA, Fnergy Comsumption and Conservation Potential, 1990)). The rate of venting and flaring of associated gas is expected to decline $(\Lambda p p . M)$. The amount of imported oil, and hence the amount of oil moved by ocean-going lankers, is projected to increase by the year 2000) (IIIA, Anmual Outlook for Oil and (iuli 1999), 199()). Listimates of the amount of energy embodied in materials are hased on year 2000 projections (App. P). Refinery onergy use is modeled (qualitalively) for the year 2000 (App. H). 


\subsubsection{Emissions from Electricity Use}

This report includes data on lotal fucl-cycle, $\mathrm{CO}_{2}$-equivalent emlssions from the use of electriclty. These emission factors (in $\mathrm{g} / \mathrm{kWh}$ ) can be used to estimate greenhouse gas emissions from any electriclty-consuming process. The total $\mathrm{g} / \mathrm{kWh}$ emission factors are essentially proportional to the efficlency of generation, which means that emisstons from plants operating at efflciencles other than those assumed here can be calculated easily. Complete greenhouse-gas emission factors for electricity generatton and use are shown in Tables D.4, D.6, and D.7. Limisstons are estimated for several advanced electriclty-generating technologies, including fuel cells, and for biomass fuel cycles as well as for conventional fuels and technologhes. Production of $\mathrm{N}_{2} \mathrm{O}$ from the corona discharge from high-voltage transmissioni lines is included (see App, N).

\subsubsection{Actual Fuel Mixes Used to Generate Electricity}

In several cases discussed in this report, I estmate the actual mix of fucls used to generate the electricity used by major electricily-consuming processes rather than simply assume a nationwide average (or "generic") power mix. for example, becallse petroleum refineries use a falr amount of electricity, the emissions of greenhouse gases from the petroleum fuel cycle depend in part on the characterization of the fuels used to generate hat electricity. I estimate this mix of fuels (for U.S. consumption of petroleum fuels) by matching every major U.S. refining center with an electric utility, then obtaining data on the actual mix of fucls used by these utilties in 1988 (using various EIA publicalions, unpublished IIA data, and the Electrical World Directory of Eilectric Lttilities, 1988). I also malch the contribution (to U.S. consumption) of overseas refining with country-specific data on fuel inputs to electricity generation.

In addition, I estimate the actual input electricity mixes for U.S. uraniumenrichment plants, auto-manufacturing facilities, and corn-to-ethanol plants by using the same method as that used ic.' petroleum refineries. In most cases, the calculated mix is quite different from the national average electricity mix (Table 6). For clectric vehicles, I adapt the EPA's detalled calculation of the actual mix of power (sometimes called the "marginal" power mix) used to recharge batteries (EPA, Analysis of the Economic and Emoirommontal liffects of Electricity as an Automotion I'uel, 1990). When information on the actual mix is not available, I use the U.S. national average power mix projected for the year 2000). The results are shown in Table 6. Details are given in App. D and in the appendix associated with the fuel of interest. 


\subsubsection{Emissions from Nuclear Fuel Cycle}

This report includes an estimate of emissions from the nuclear fuel cycle. Most previous analyses assume zero enissions from the nuclear fuel production and use cycle, despite the fact that urantum enrichment requires a substantial amount of electricity -- electricity that at present is produced almost entircly by coal-fired plants. Other stages of the uranium-to-power cycle also produce greenhouse gases. This analysis estimates greenhouse gas emissions from the mining, milling, conversion, enrichment, and transport of uranium and from the fabrication and disposal of fuel (App. I). Mortimer's (no date) recent analysis produces very similar results.

\subsubsection{Natural Gas Production and Transmission}

The production and transmission of NG is analyzed in detail. This fuel is an important and difficult-to-analyze transportation feedstock. It is important because it can be made into methanol, CNG, or LNG (or even gasoline) and used to generale electricity; it is difficult to analyze because it is coproduced with oil and because natural gas liquids (NGL) plants produce both dry gas and NGL..

This model first separates the values for energy used for NG production from those for energy used for oll production, then allocates energy used at NGL plants to both NGLs and dry gas (EIA, Natural Gas Annual and other publications, see App. G; U.S. Bureau of the Census, 1987 Census of Mineral Industries, Subject Series, Finels and Electric Energy Consumed, 1990). Leaks and venting of $\mathrm{CH}_{4}$ and $\mathrm{CO}_{2}$ are quantified.

Information from a small phone survey of major gas transmission companies was used to break down the energy used to transmit NG into electricity for clectricmotor-driven compressors, NG for gas-turbine-driven compressors, and NG for reciprocating-engine-driven compressors. This breakdown is important because different types of compressors emit different amounts of non- $\mathrm{CO}_{2}$ greenhouse gases (Table A.1).

Finally, the model accounts for the fact that the $N G$ used to make methanol probably will not be transported as far as the NG used to make C.NG or L.NC, and it will probably not go through a low-pressure gas-distribution system.

\subsubsection{Energy Used to Refine Crude Oil}

The energy used to refine crude oil is allocated to individual products. The model starts with detailed input data on the amounts and types of energy required to refine crude oil based on data in EIA's Petroleum Supply Anmual and other sources (see App H). It then allocates total refinery fuel use to gasoline, diesel fuel, and 
residual fuel specifically, on the basis of data in several papers and reports that show refinery energy use by process area. Next, these results are updated to account for the reformulation of gasoline and the reduction in the sulfur content of diesel fuel required under the new Clean Air Act Amendments. The final process-fuel requirements for gasoline, diesel fuel, residual oil, and $L P G$ are multiplied by emission factors for each of the process fuels. As a result of this apportioning of emissions from refineries, gasoline is assigned a much larger share of refinery energy use, and diesel fuel a much smaller share, than in most previous analyses. Details are given in App. H.

Although the model does estimate refining energy intensity separately for gasoline, diesel fuel, and residual fuel, it does not calculate this intensity as a function of the mix of products demanded. Nelther does it consider how changes in the product mix might affect demand for (and recovery energy associated with) different kinds of crude oil. In general, the method assumes that the net effect of using a mile's worth of an alternative fuel is elimination of a mile's worth of gasoline or diesel fuel, with concomitant eliminations in the crude oil use and processing stagres. The method ignores how the use of an alternative (substitute) fuel might change the price of petroleum fuels and thereby affect demand for (and emissions from) petroleum products, or how a change in the product slate might affect prices, demand, and emissions. These areas may be appropriate for future research.

\subsubsection{Emissions from Wood-Derived Fuels}

This model estimates emissions of greenhouse gases that result from the production and use of woody biofuels: ethanol, methanol, and SNG from wood. The calculation is made on the basis of a detailed review of the energy requirements for short-rotation, intensive cultivation and for the conversion of wood to transportation fuels (App. K).

\subsubsection{Corn-to-Ethanol Process}

This report attempts to settle some of the points of contention in estimates of greenhouse gas emissions from processes that convert corn to ethanol. It does so by analyzing in detail the amount of fertilizer used to grow corn, the amount of energy used by corn farmers, and the amount of emissions that should be assigned to by-products of the corn-to-ethanol process. Previous analyses that estimate energy and fortilizer inputs to corn farming on the basis of separate data sets on corn yield per acre, fertilizer use per acre, and energy use have not agreed on appropriate values (Segal, 1989; Ho, 1989). As discussed in App. K, because corn yield is related (1) the amount of energy and fertilizer used, one should estimate corn yield as a function of fertilizer and energy input. This procedure is done here on the basis of several data series from the U.S. Department of $\Lambda$ griculture ( $А$ pp. K). 
In the base-case analysis, I assume that coal is used to provide the process energy for a corn-to-ethanol plant, but in the scenario analyses, I consider the effect of using NG or corn-crop residue as process fuels. I estimate the by-product credit in two ways: first, by calculating the amount of energy saved in specific priducts displaced by the by-products, and second, by considering the total energy content of the by-products.

Finally, this analysis covers both emissions of $\mathrm{N}_{2} \mathrm{O}$ from the denitrification of fertilizer (which were first calculated by Stefan Unnasch of Acurex Corporation, in Mountain View, California) and emissions of $\mathrm{NO}_{x}$ from the nitrification of fertilizer. Details are given in App. $\mathrm{K}$.

\subsubsection{Liquefied Petroleum Gas}

Most previous analyses do not include LPG. (The Mueller, 1990, report is an excoution.) Yet the LPG fuel cycle produces the smallest amount of greenhouse gas emissions of all the fossil fuel options for internal-combustion-engine vehicles (ICEVs), so LPG should not be ignored as a potential fuel source. Greenhouse gas emissions from the use of LPG as a fuel depend on how much of the LPG comes from refineries and how much comes from NGL plants, because refineries use more energy to produce LPG than do NGL plants. The source of the I.PG, in turn, perhaps can be inferred from the composition of the LPG (its percentage of propane and butane), because NGL plants produce a greater share of total (NGL plus refinery) butanes than they do of total propane. This model calculates greenhouse gas emissions from both refineries and NGL plants, then weighs the final result according to the amount of propane and butane in the I.PG and the amount of propane and butane produced from refineries and NGL plants.

\subsubsection{Reformulated Gasoline and Diesel Fuels}

Reformulated gasoline and diesel fuels are used for the base-case analysis, for comparison with alternative fuels in the year 2000. Reformulating gasoline to be less volatile and to produce less NMOCs and toxic compounds will have several partially counterbalancing effects. It will take more energy to make reformulated gasoline (including the extra energy to make the oxygenates), and reformulated gasoline will have a lower energy density than regular gasoline (primarily because of the oxygenates). These factors will increase per-mile greenhouse gas emissions from reformulated gasoline when compared with nonreformulated gasoline. However, reformulated gasoline will have a lower carbon content than nonreformulated gasoline, because of its lower aromatics and higher oxygen content, and this will reduce per-mile $\mathrm{CO}_{2}$ emissions. The reduction of the sulfur content of diesel fuel will increase refinery energy requirements and hence increase emissions of greenhouse gases. Appendixe' $\mathrm{C}$ and $\mathrm{H}$ discuss these effects. 


\subsubsection{Advanced Battery-Powered and Fuel-Cell-Powered Electric-Motor- Driven Vehicles}

Most previous analyses have not included battery-powered and fuel-cellpowered vehicles, even through it has long been known that they have great potential to reduce emissions of greenhouse gases. This analysis considers a wide range of fuels and feedstocks for both battery-powered and fuel-cell-powered electric vehicles.

\subsubsection{Alternative-Fuel Vehicle Efficiency}

The $\mathrm{mi} / 10^{6} \mathrm{Btu}$ efficiency of alternative-fuel vehicles relative to the $\mathrm{mi} / 10^{6} \mathrm{Btu}$ efficiency of gasoline and diesel vehicles is analyzed in detail. Greenhouse gas emissions from alternative-fuel ICEVs are directly related to the thermal efficiency of the engines. Many factors affect the thermal efficiency of alternative-fuel vehicles relative to gasoline vehicles. In the future, emission standards will probably be the most important of these. The potential gain in thermal efficiency to be achieved with alternative fuels will probably be constrained by the $0.40 \mathrm{~g} / \mathrm{mi} \mathrm{NO}_{\mathrm{x}}$ standard required under the new Clean Air Act Amendments. Appendix $\mathrm{B}$ analyzes the effect of the $0.40 \mathrm{~g} / \mathrm{mi} \mathrm{NO}_{\mathrm{x}}$ standard on the possibility of using lean-burn technology to improve the relative thermal efficiency of alternativefuel vehicles.

Greenhouse gas emissions from battery-powered electric vehicles (EVs) are especially sensitive to the energy consumption rate $\left(\mathrm{mi} / 10^{6} \mathrm{Btu}\right)$ relative to that of gasoline ICEVs. I compare the measured values for city-cycle energy consumption (from the battery terminals) of $10 \mathrm{EVs}$ with the measured city-cycle mpg of the internal-combustion-engine version of the same vehicles, holding vehicle weight constant. I then factor in the efficiency effect of vehicle weight, the efficiency of battery recharging, and the efficiency of the battery itself to arrive at a relative fuel consumption rate for EVs in $\mathrm{mi} / 10^{6} \mathrm{Btu}$. See App. B, especially Table B.1, for details.

\subsubsection{Unusual Sources of Emissions}

This report covers several sources typically not included in greenhouse gas analyses. They include $\mathrm{CO}_{2}$ emissions from the use of calcium carbonate $\left(\mathrm{CaCO}_{3}\right)$ to scrub $\mathrm{SO}_{2}$ from the flue gas of power plants; $\mathrm{N}_{2} \mathrm{O}$ and $\mathrm{NO}$ emissions from the denitrification and nitrification of fertilizer; $\mathrm{CO}_{2}$ emissions from NG fields; $\mathrm{N}_{2} \mathrm{O}$ emissions formed by the corona discharge from power lines; and emissions from the use of energy to build, maintain, and administer trains, trucks, ships, and pipelines. 


\subsubsection{Methane and Nitrous Oxide}

Estimates of $\mathrm{N}_{2} \mathrm{O}$ and $\mathrm{CH}_{4}$ emissions from fuel combustion are derived from a comprehensive database. Data on the $\mathrm{CH}_{4}$ and $\mathrm{N}_{2} \mathrm{O}$ emissions from vehicles powered by gasoline, diesel fuel, methanol, and NG are compiled in Tables M.1 and N.1 and analyzed in Apps. $\mathrm{M}$ and $\mathrm{N}$. The analysis produces some interesting results. For example, it shows that the $\mathrm{CH}_{4}$ emissions from "flexible-fuel" methanol/gasoline vehicles are proportional to the gasoline content of the fucl.

All available EPA AP-42 data on $\mathrm{CH}_{4}$ emissions (from power plants, trains, ships, engines, etc.) are used in the analysis. For refineries, I use data on $\mathrm{CH}_{4}$ emissions reported by refineries to air quality control boards in Texas and California (App. M).

Early estimates of $\mathrm{N}_{2} \mathrm{O}$ emissions appear to be in error because of a "sampling artifact." This analysis uses recent analyses of $\mathrm{N}_{2} \mathrm{O}$ emissions as a function of fuel type and combustion conditions (Table N.2). Details are given in App. N.

\subsubsection{Venting and Flaring}

Venting and flaring from coal mines, NG operations, and oil wells are analyzed in detail. Emissions of $\mathrm{CH}_{4}$ from coal mining are calculated as a function of the $\mathrm{CH}_{4}$ content of various ranks of coal and the rate of production for the various ranks; $\mathrm{CH}_{4}$ leakage from sidewalls and pillars is accounted for.

Leaks from NG operations are categorized as coming from three sources: production fields, transmission lines, and distribution lines. Recent estimates of actual leak rates (as opposed to estimates of unaccounted-for gas) are used. Gas that is used by very-high-volume consumers, such as methanol plants and eiectricity plants, is assumed to not go through a low-pressure distribution system. This point is important, because the bulk of total leakage from an NG system occurs in the distribution lines.

Venting and flaring of associated gas are analyzed in detail, with consideration given to such issues as the breakdown between venting and flaring, the correct assignment of venting and flaring to oil and gas, and the completeness of the available data. A weighted-average venting and flaring rate is calculated, based on the rates projected for eight regions in the year 2000 and the amount of of oil that the United States will import from each of those regions. 


\subsubsection{Nitrogen Oxide, Carbon Monoxide, and Nonmethane Organic Compounds}

The base-case analysis considers emissions of $\mathrm{NO}_{x}, \mathrm{CO}$, and NMOCs in all fuel cycles. Emissions from the base-line petroleum-fuel vehicles are estimated by adjusting MOBILE4 results to account for changes required under the new Clean Air Act Amendments. Emissions from alternative-fuel vehicles are estimated relative to the gasoline case, on the basis of a detailed analysis of the expected difference in emissions between alternative-fuel vehicles and petroleum-fuel vehicles (Sperling and DeLuchi, 1991; see App. B). The base-case analysis also considers emissions of $\mathrm{CO}, \mathrm{NO}_{x}$, and NMOC from petroleum refineries, power plants, methanol plants, trains, ships, and other sources (Table A.1).

\subsubsection{2 $\mathrm{CO}_{2}$-Equivalent Emissions}

To compare the aggregate greenhouse effect of all emissions from all fuel cycles, the global warming potential of all greenhouse gases must be expressed by a single unit or measure. This model uses a detailed and conceptually correct procedure to convert $\mathrm{CI}_{4}, \mathrm{~N}_{2} \mathrm{O}, \mathrm{CO}, \mathrm{NMOC}$, and $\mathrm{NO}_{x}$ emissions to $\mathrm{CO}_{2}$ emissions with the same temperature effect. This analysis examines recent work by Shine et al. (1990)), Rodhe (1990), Lashof and Ahuja (1990)), and Wilson (1990), who provide good analyses of how to convert non- $\mathrm{CO}_{2}$ greenhouse gas emissions into "equivalent" $\mathrm{CO}_{2}$ emissions. It studies the data and formulas used in these analyses and presents further calculations that clarify the use of these conversion factors. Table 8 shows the conversion factor used in this analysis. Because conversion factors are a function of how far one looks into the future, and because it is not possible to specify the exact appropriate time horizon, I present results for short-, medium-, and long-term horizons. However, as I argue in App. O, global warming is a long-term problem, and it is difficult to justify using a time horizon as short as 20 years.

\subsubsection{Light-Duty and Heavy-Duty Vehicles}

This report examines the combined effect of greenhouse gas emissions from both light-duty vehicles (LDVs) and heavy-duty vehicles (HDVs). Most previous analyses compare alternative fuels with gasoline for light-duty applications. The few that do compare alternative fuels with diesel fuel for heavy-duty applications conclude that most alternative fuels fare worse than diesel fuel, and this finding is confirmed here. However, so far, no one has pursued the implication of this finding; namely, that since an alternative-fuels program is likely to include heavy-duty as well as light-duty applications (consider the new emission standards for heavy-duty trucks and buses, which are likely to force the use of alternative fuels), the overall effect of an alternative-fiels policy (the topic of interest) will be less favorable than will its effect in the LDV sector only. 
TABLE 8 Factors for Conveiting Greenhouse Gas Emissions to $\mathrm{CO}_{2}$-Equivalent Emissions, Mass Basisa

\begin{tabular}{|c|c|c|c|c|c|c|}
\hline Time (yr) & $\mathrm{CH}_{4}^{\mathrm{b}}$ & $\mathrm{N}_{2} \mathrm{O}$ & $\mathrm{CO}$ & NMOC-CC & $\mathrm{NO}_{x} \mathrm{~d}$ & $\mathrm{CFC}-12^{\circ}$ \\
\hline 20 & 60 & 270 & 7 & 36 & 150) & 7,100 \\
\hline 100 & 20 & 290 & 3 & 13 & 40) & 7,300 \\
\hline 500 & 9 & 190 & 2 & 7 & 14 & 4,500 \\
\hline
\end{tabular}

aFactors are taken from the Intergovernmental Panel on Climate Change (IPCC) document (Shine et al., 1990), with some modifications. They account for indirect effects, such as the effect of $\mathrm{CO}, \mathrm{NMOC}$, and $\mathrm{CH}_{4}$ on the concentration of $\mathrm{O}_{3}$. See App. $\mathrm{O}$ for details.

bI reduced the IPCC's values by a token amount to account for recent evidence that the radiative adsorption strength of $\mathrm{CH}_{4}$ may be less than previously believed (Gamache and Colomb, 199()).

CThis expresses the warming effect per unit of carbon (C) weight. It is equal to the IPCC factors divided by ().85. (1 estimate that the generic nonmethane organic compound (NMOCI content in the IPCC analysis is 85\% carbon). See App. O.

dThe U.S. Environmental Protection Agency (EPA), in its AP-42 report, expresses $\mathrm{NO}_{x}$ emissions from power plants and vehicles as $\mathrm{NO}_{2}$ emissions, even though most of the $N O_{x}$ in the exhaust gas is actually NO. It does so because the measuring process converts $\mathrm{NO}$ to $\mathrm{NO}_{2}$. The IPCC's $\mathrm{NO}_{x}$ conversion factor is also based on $\mathrm{NO}_{2}$ (Shine et al., 1990), so the conversion factor and the emission data have the same basis.

"Used to calculate $\mathrm{CO}_{2}$-equivalent of $\mathrm{CFC}$ emissions from vehick airconditioning systems (in App. (2).

In this report, I estimate the aggregate effect of alternative-fuels programs that will probably inclucte both LDVs and HDVs by neighting light-duty and heavy-duty emission factors (in $\mathrm{g} / \mathrm{mi}$ ) by the proportion of vehicle miles traveled (VMT) by LDVs and IIDVs. Even though the number of VMT by HDVs is small, most alternative fuels fare so much worse in heavy-duty applications that inclusion of even the small amount of HDV VMT significantly changes the result. In some cases, this change alters the nature of tho overall conclusions qualitatively. See App. B for more details.

\subsubsection{Scenario Analyses}

Scenario analyses are used to test the effect of varying important and uncertain variables. Economic, technical, and political uncertainties make it impossible to use point estimates of many of the major variables, including the efficiency of alternative-fuel vehicles rolative to gasoline vehicles, the mix of fucls 
used to generate electricity for electric vehicles, the efficiency of fuel conversion processes, and tailpipe emissions of non- $\mathrm{CO}_{2}$ greenhouse gases. I use many scenario analyses to examine the effect of uncertainty with respect to these and many other variables. 


\section{BASE-CASE ANALYSIS}

\subsection{GENERAL DESCRIPTION OF RESULTS}

Tables 3 through 7 show the base-case assumptions and calculated results for the following parameters:

- Overall energy intensity of each stage of the various fuel cycles (in Btu of process fuel per Btu of net product output),

- Type of energy used at each stage of the fuel cycle,

- Venting and flaring of $\mathrm{CH}_{4}$,

- Electricity mixes for several processes such as recharging EVs or compressing NG,

- Efficiency of electricity generation, and

- Amount of greenhouse gases emitted (in grams per $10^{6} \mathrm{Btu}$ of delivered fuel).

The base case for vehicles compares projected fuel-cycle emissions from alternative-fuel vehicles with those from gasoline LDVs and diesel HDVs in the year 2000. The base-case vehicle parameters, including the relative thermal efficiency of alternative-fuel ICEVs, the relative power-train efficiency of battery-powered IVS, the efficiency of batteries and battery recharging, the characteristics of fuel storage systems, and the desired driving range, are shown in Table 2 and documented in Apps. B, M, and $\mathrm{N}$. All the alternatives except the EV are compared with the gasoline vehicle under a condition that represents combined city/highway driving $(30 \mathrm{mpg})$. The comparison of the EV with the gasoline vehicle assumes cily driving only (24.5 mpg), because EVs will usually not be used for long highway trips. The base-case diesel HDV gets $6 \mathrm{mpg}$. In general, I assume that alternative-fuel I.DV s are more efficient than gasoline LDVs and that alternative-fuel HDVs are less ceficiont than diesel HDVs.

The base case for methanol LDVs and HDVs assumes that methanol is made primarily from remote NG through the use of state-of-the-art conversion technology. The mix of power plants dispatched to meet the incremental electricity demand arising from $\mathrm{EV}$ recharging patterns is shown in Table 6 and discussed in App. D. I assume that hydro, geothermal, biomass, solar, and wind plants do not emil greenhouse gases (see App. D for justification). The base case for hydrogen ICIV s and fuel-cell vehicles assumes that either solar or nuclear power is used 10 make hydrogen from water, then the hydrogen is compressed or liquefied on the basis of the projected U.S. average power mix in the year 2000). The base case for ethanol 
from corn assumes that coal is used as a process fuel. The base case for bio-methanol and bio-SNG assumes gasification of wood. The base case assumptions about the efficiency that is achieved in converting NG to methanol, coal to methanol, and corn to ethanol are shown in Table 3 . The base-case assumptions with respect to electricity generation are discussed in $\Lambda p p$. D.

Given the input data and assumptions discussed above and a lot of other input data not discussed in this section, the emissions model calculates the number of grams of $\mathrm{CO}_{2}$-equivalent greenhouse gases (actual $\mathrm{CO}_{2}$ emissions plus the $\mathrm{CO}_{2}$ equivalent of $\mathrm{CH}_{4}, \mathrm{CO}, \mathrm{NMOCs}, \mathrm{NO}_{x}$, and $\mathrm{N}_{2} \mathrm{O}$ ) that are emitted per mile of travel by a vehicle or per kilowatt-hour of electricity delivered to end users. For vehicles, the $\mathrm{g} / \mathrm{mi}$ results are broken down by stage of the fuel production and use cycle in Table 9, by $\mathrm{CO}_{2}$-equivalent emissions of individual greenhouse gases in Table 10, and as a function of the fuel efficiency of motor vehicles in Table 11. Finally, Table 12 shows the results of comparing the alternative-fuel vehicles to the petroleum-fuel vehicles, expressed as a percentage change, for many scenario. anilyses. The percentage changes given in Table 12 account for emissions from the manufacture and assembly of materials for vehicles. (As discussed in App. P, emissions from the manufacture of materials for major facilities, such as power plants, appear to be quite minor.) It is relatively easy to calculate the percentage changes without accounting for materials by using the data from Tables 9 and 12 . (Tables 9 through 12 appear later in this document, closer to the pages that discuss (hem in detail.)

\subsection{RESULTS FOR ELECTRICITY USE (Fig. 1 and Tables 13, D.4, D.7, and D.8)}

\subsubsection{Different Fuels Result in Different Emissions}

Over all the scenarios and time horizons considered here, the NG-to-power fuel cycle produces about $50-60 \%$ of the $\mathrm{CO}_{2}$-equivalent emissions of the coal-topower fuel cycle (Fig. 1, Table 13, and Tables D.4 and D.7 in App. D). This result occurs when future advanced NG turbines are compared with future integrated coal gasification/advanced gas-turbine plants, when fuel-cell technologies are compared, and when current boiler technologies are compared. There do not appear to be any conditions in the United States under which the use of NG to generate electricity would contribute anywhere near as much to global warming as would the use of coal.

The current nuclear fuel cycle, which uses gaseous-diffusion enrichment technology, produces about $6 \%$ of the $\mathrm{CO}_{2}$-equivalent emissions of the current coalto-power fuel cycle. Most of these emissions come from the coal-fired power plants that supply electricity to the two operating DOE gaseous-diffusion uraniuminrichment facilities. If, in the future, uranium is enriched not by gaseous diffusion 

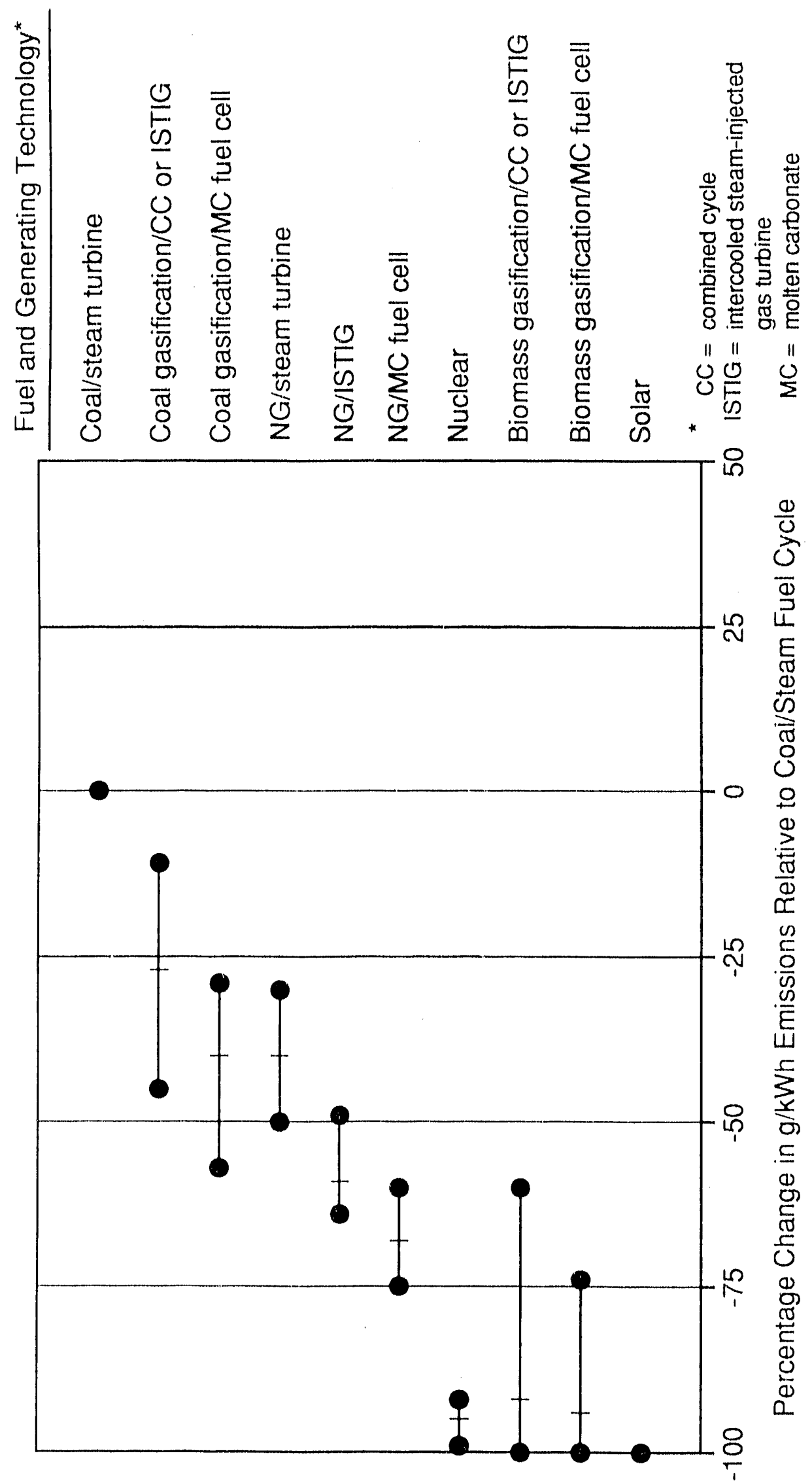

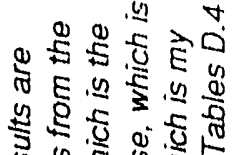

पू

\&

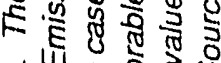

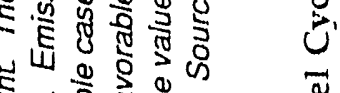

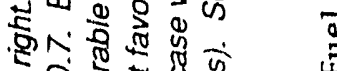

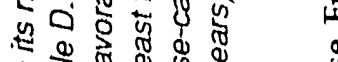
은

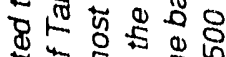
जु

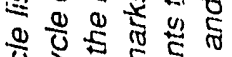

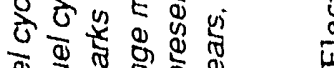
ज经造 \&

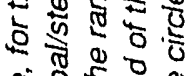
จ 80.525 वे कह

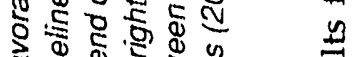
产高 प्⿹

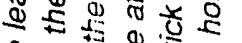
ฐ

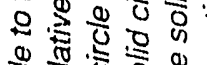

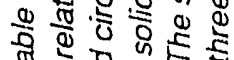
की

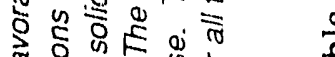
空忽造 कह कू ह क ष

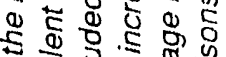

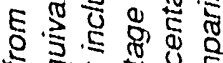

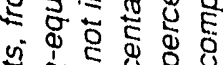
ง फुण ठ \&

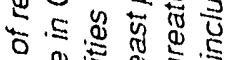
os 0,5 कृ त论 悉

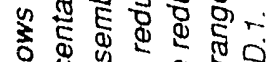
एิ के \& 5

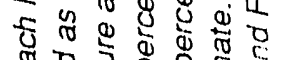

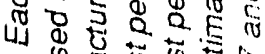
ن门

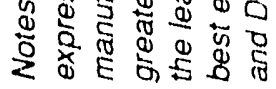


TABLE 13 Total Fuel-Cycle $\mathrm{CO}_{2}$-Emissions of Greenhouse Gases from Electricity Generation, as a Iunction of Net Generation Efficiency for 20-Year, 100-Year, and 500-Year Time Horizons ${ }^{a}$

$\mathrm{CO}_{2}$-Equivalent Emissions por Kllowatt-Hour of Enorgy Dollvered to End Usors, by Source (g)

Cieneration Sconariob

Coal

$\begin{array}{cc}\text { NG } \\ \text { Boiller } & \text { Turbine/ } \\ \text { Other }\end{array}$

Mothanol

from NG Biomass

1(1) yitur time horizont.

1. $32 \%$ officioncy

2. $35 \%$ efficiency

3. $38 \%$ efficiency

4. $38 \%$ efficioncy, low emisstons

5. 4(1)", efficiency

6. 4(1) efficiency, low emissions

7. Noi combined cycle

8. Fuidized-bed combustion

9. Cissification/gas turbine

11). ISI'IC:

11. CIRISTIC:

12. Molten-carbonate fuel cell

\begin{tabular}{|c|c|c|c|c|}
\hline 1,335 & $1,1,32$ & $8(1) 3$ & 793 & 69 \\
\hline $1,22()$ & $1,(0,32$ & 734 & 7.25 & 83 \\
\hline 1,123 & 949 & 676 & 6638 & 22 \\
\hline 1,079 & 917 & 6.53 & $650)$ & \\
\hline $1,(067$ & $(x)()$ & 6,43 & 634 & \\
\hline $1,(025$ & 871 & 620 & $\begin{array}{l}617 \\
565\end{array}$ & \\
\hline
\end{tabular}

1,768

949

526

466

781

114

162

$1,(173$

$1,() 49$

$1,(0)(1)$

5)(1) yeur lime horizon'

1. $32 \%$ officioncy

2. $35 \%$ efficiency

3. $38 \%$ officiency

4. $38 \%$ efficiency, low emissions

1,219

1,114

$1,(1) 25$

$1,(110$

8. Fluidired-bed combustion $\quad 1,470$

9. Casification/gas turbine

$(x) 4$

I). ISTIC,

12. Molten-carbonate fuel coll

751

$\begin{array}{rll}1,(161 & 738 & 735 \\ 968 & 673 & 672 \\ 890 & 6.21 & 618 \\ 879 & 612 & 612 \\ & & \\ & & 495 \\ & & 40.3\end{array}$

$\begin{array}{rrr}735 & 60 & 1,174 \\ 672 & 72 & 1,(172 \\ 618 & 17 & 986 \\ 612 & & 991\end{array}$

495

76

57

?) ye'ur lime horizont

1. $32 \%$ efficiency

2. $35 \%$ officiency

3. $38 \%$ officiency

4. $38 \%$ cfficiency, low emissions

1,779

1,625

1,496

1,328

$2,(098$

1,407

1,283

1,175

1,055

$1,(016$

929

855

$1,059 \quad 799 \quad 788$

$\begin{array}{rr}10() & 1,689 \\ 118 & 1,541 \\ 38 & 1,399 \\ & 1,323\end{array}$

8. Fluidized-bed combustion

$1,4(0)$

10. IST'is:

12. Molten-carbonate fuel cell

89() 
but by the considerably more effident laser-isotopenseparallon techndque or by gan centrifuge, the nuclear fuel cycle will produce only $2 \%$ of the emisstons of cont find cycle.

Solar power will do even better, however. It will eliminate all emissions of greenhouse gases, except $\mathrm{N}_{2} \mathrm{O}$ emissions from high-voltage transmission lincit and emissions from the use of energy to build power plants, and both these sources ar' quite small. The solar power cycle produces less greenhouse gases than does any electricity-generating fuel cycle.

Under the 100- and 500-year time horizons (corresponding to the conversion factors of Table 8 ), oil-fired plants produce $85-87 \%$ the total fuel-cycle, $\mathrm{CO}_{2-}$ equivalent emissions of coal-fired plants. Under the 20-year time horizon, vil-fired plants produce about $80 \%$ of the emissions of coal-fired plants. Oil improves its standing relative to coal in the $2(1-y e a r$ case beause the coal cycle produces more non- $\mathrm{CO}_{2}$ greenhouse gas emissions than does the oil cycle (the coal cycle produces a large amount of $\mathrm{CH}_{4}$ emissions from coal mining and a large amount of $\left.\mathrm{NO}\right)_{x}$ emissions from power generation) and because non- $\mathrm{CO}_{2}$ greenhouse gnses are weighted much more heavily in the short-term case. However, as argued in $\Lambda$ pp. (), there is little justification for choosing a poriod of less than 10) years.

\subsubsection{Electricity-Generating Efficiency Correlates with Emissions}

Complete fuel-cycle, $\mathrm{CO}_{2}$-equivalent emissions from electricity gencration are, as expected, almost directly proportional to the efficiency with which that electricity is generated (Table D.5). This situation occurs because both fuel use (and hence $\mathrm{CO}_{2}$ emissions) and emissions of non- $\mathrm{CO}_{2}$ gases are proportional to the efficiency of the power plant. Emissions of non- $\mathrm{CO}_{2}$ gases are proportional to efficiency because power plant emissions are regulated per unit of fuel input, not per unit of electricity output. $\mathrm{N}_{2} \mathrm{O}$ emisisions from transmission lines are not relinted to the efficiency of generation, but are too small to upset the general relationship between efficiency and emissions.

\subsubsection{There Are Several Significant Emission Sources}

There are several significant sources of non- $\mathrm{CO}_{2}$ greenhouse gases within the electricity fuel cycles (Table D.8): NOx emissions from power plants, $\mathrm{CH}_{4}$ emissions from coal mines and $N G$ production and transmission operations, $\mathrm{N}_{2} \mathrm{O}$ ) emissioms from power plants and high-voltage transmission lines, and $\mathrm{NO}_{\mathrm{x}}$ emissions from upstream processes for $\mathrm{NG}$ and oil production. Together, non- $\mathrm{CO}_{2}$ greenhouse gases account for $10-15 \%$ of total fuel-cycle, $\mathrm{CO}_{2}$-equivalent, $\mathrm{g} / \mathrm{kWh}$ emissions of greenhouse gases from fossil fuel plants and for $24 \%$ of fuel-cycle emissions from nuclear power plants. Non- $\mathrm{CO}_{2}$ greenhouse gases are more important in the nuclear fuel cycle because standby diesel generators emit a large amount of nom- $(\mathrm{C})_{2}$ 
greenhouse gases (see the diesel-engine emission factors of 'Table A.1). However, the emissions from these generators need to be better characterized.

In the base case for coal, the $\mathrm{CO}_{2}$ equivalent emisstons of $\mathrm{CH}_{4}, \mathrm{NMOC}_{2} \mathrm{CO}$, $\mathrm{N}_{2} \mathrm{O}$, and $\mathrm{NO}_{x}$ that come from fuel combustion at the generating facilly constitute $9 \%$ of total fuel-cycle, $\mathrm{CO}_{2}$-equivalent emissions (Tables D.4 and D.8). $\mathrm{CO}_{2-}$ equivalent emisstons of these gases from an oll-fired boller and a gas-fired turbine constitute $7 \%$ of their respective total fuel-cycle emissions. The corresponding figure for gas-fired bollers is $8 \%$. The higher percentage for coal is primarily a result of the higher $\mathrm{NO}_{x}$ cmission rate associated with coal combustion.

\subsubsection{Coal Fuel Cycle Generates More Methane Emissions than Does Gas Fuel Cycle}

The global warming potential (in grams of $\mathrm{CO}_{2}$-eguivalent emisstons per kilowatt-hour of generation) of $\mathrm{CH}_{4}$ emissions from coal mines in the coal-to-power fucl cycle exceeds that of $\mathrm{CH}_{4}$ leaks from $\mathrm{NG}$ production and transmission in the N(i-lo-power cycle by a factor of four (Table D).8). Only if the gas lines serving power plants were to lose as much $N G$ as the low-pressure distribution systems were previously thought to (around 3\% of throughput) would the $\mathrm{CH}_{4}$ emissions from the NG-to-power cycle become more important than those from the coal-topower cycle. However, this situation secms extremely unlikely. First, as discussed in App. M, all recent estimates of gas leaks per se (as opposed to estimates of gencrally unaccounted-for gas) suggest that much less than 1\% of throughput is lost from modern low-pressure distribution systems. Second, the systems serving power plants are not likely to be as leaky as low-pressure gas-distribution systems, because gans pressure and throughput at power plants are much higher, and because it is casier and more important to monitor leaks in high-pressure, high-volume systems.

This analysis also indicates that NO emissions from power plants contribute substantially more to global warming than do $\mathrm{CH}_{4}$ emissions and leaks (Table D.8), although it must be remembered that the $\mathrm{NO}_{x}$ equivalency factor of Table 8 is both relalively high and very uncertain. It therefore follows that concerns about $\mathrm{CI}_{4}$ emissions from the NG-to-power fuel cycle may be misplaced, both because $\mathrm{CH}_{4}$ (rmissions themselves are likely to be small and because other non- $\mathrm{CO}_{2}$ greenhouse gases, such as $\mathrm{NO}_{x}$, may be more important with respect to global warming.

\subsubsection{Production and Transport Stages Generate a Lower Percentage of Emissions in Coal Fuel Cycle than in Oil or Gas Fuel Cycles}

In the base case for coal (Table D.4), $\mathrm{CO}_{2}$-equivalent emissions from feedstock mining, preparation, and transport are $x^{\prime \prime} \%$ of total fuel-cycle, $\mathrm{CO}_{2}$-equivalent imissions. The corresponding figures for oil and gas are $16 \%$ and $14 \%$. This result wecurs because it thkes more energy to transport oil and gas than coal, and because 
coal-fired power plants themselves produce more greenhouse gases than do oll- or gas-fired power plants.

\subsubsection{Emission Results Vary with the Time Frame}

For all fossil fuels, total fuel-cycle, $\mathrm{CO}_{2}$-equivalent emissions are only $5-10 \%$ higher in the 100-year case than in the 500-year case, but are $15-33 \%$ higher in the 20-year case than in the 100-year case. This result illustrates the combired importance of the magnitude of emissions of non- $\mathrm{CO}_{2}$ greenhouse gases and the time horizon of the analysis. There can be a considerable difference in the absolute emissions levels calculated for a short-term versus a medium-term analysis. However, it is difficult to justify using a 20-year time horizon (see Ap!, O).

\subsubsection{Cutting $\mathrm{NO}_{x}$ and $\mathrm{SO}_{x}$ Emissions Has Less Effect in the Long Term}

The low-emissions scenario, in which $\mathrm{NO}_{x}$ and $\mathrm{SO}_{x}$ emissions from all power plants are cut by $50 \%$ from the base-case level, results in 1-4\% lower total fuel-cycle greenhouse gas emissions in the 100)- and 50(0-year cases. In the 20-year case, the lowemissions scenario results in about $10 \%$ lower total emissions. This result occurs because in the 20-year case, the non- $\mathrm{CO}_{2}$ gases -- and hence the cuts in emissions of these gases -- are weighted more heavily.

\subsubsection{High-Efficiency, Low-NO ${ }_{x}$, Gasification and Advanced Gas-Turbine Technologies and Fuel Cells Could Greatly Reduce Fmissions from Electricity Use}

High-efficiency, low- $\mathrm{NO}_{x}$, gasification and advanced gas-turbine technologies or, better still, fuel cells, are among the most promising moans of reducing emissions of greenhouse gases from the use of electricity.

\subsubsection{Natural Gas}

A fuel cycle using a high-efficiency, low-NOx, intercooled steam-injected gas turbine (see App. D) would produce nearly two-thirds less fuel-cycle greenhouse gases than does the current U.S. coal-lo-power cycle. However, the use of hightemperature fuel cells would provide even higher efficiency and lower emissions of criteria pollutants, and hence even lower fuel-cycle $\mathrm{CO}_{2}$-equivalent emissions. 


\subsubsection{Coal}

The integrated coal gasification/advanced gasmturbine technologies, using either combined-cycle turbines or intercooled steam-injected gas turbines, are the most promising means of reducing greenhouse gas emissions from coal-based combustion plants. The combination of (1) high efficlency, (2) a small amount of $\mathrm{NO}_{\mathrm{x}}$ emissions, and (3) a method of removing sulfur that does not produce $\mathrm{CO}_{2}$ results in lower total fuel-cycle greenhouse gas emissions than does the current petroleum-toelectricity fuel cycle. Fuel cells, however, would allow for an even higher efficiency and result in an even smaller amount of $\mathrm{NO}_{x}$ emissions, hence leading to even fewer greenhouse gas emissions. In fact, fuel cells are the most efficient and least polluting coal conversion technology known (Rastler, 1990). An integrated gasification/molten-carbonate fuel-cell cycle, using internal reforming (see App. D), would produce about $40 \%$ less fuel-cycle $\mathrm{CO}_{2}$-equivalent emissions than does a conventional coal-to-steam-power fuel cycle.

On the other hand, the possibility of the extremely high $\mathrm{N}_{2} \mathrm{O}$ emissions that could result from low-temperature combustion and from the use of limestone injection to remove $\mathrm{SO}_{x}$ tends to undermine the moderately high efficiency of fluidized-bed combustion (FBC), making this advanced technology much less attractive than gasification/gas-turbine generation from a greenhouse standpoint. limissions of $\mathrm{N}_{2} \mathrm{O}$ from $\mathrm{FBC}$ need to be verified, however.

\subsubsection{Biomass}

The efficient use of biomass in gasification/advanced gas-turbine power plants would produce relatively few greenhouse gas emissions, because any $\mathrm{CO}_{2}$ emissions per se would not count as a net emission to the atmosphere. In fact, the greenhouse gas emission rate from the biomass gasification/gas-turbine fuel cycle would be as low as that from the current nuclear fuel cycle, except under the 20-year horizon. (The biomass fuel cycle would fare less well under the 20-year horizon, because a large fraction of its fuel-cycle emissions would be non- $\mathrm{CO}_{2}$ greenhouse gases from biomass production and combustion, whereas in the nuclear fuel cycle, most of the greenhouse gas emissions are $\mathrm{CO}_{2}$.) The use of gasified biomass with fucl cells instead of turbines would result in even fewer emissions. Furthermore, if a biofuel development effort permanently increased the standing stock of carbon in biomass, it would receive a one-time $\mathrm{CO}_{2}$ "sequestering" credit that could cancel decades of fuel-cycle greenhouse gas emissions, including emissions from the use of energy embodied in equipment and facilities. 


\subsection{RESULTS FOR VEHICULAR FUELS}

\subsubsection{Comparison of Emissions from Various Fuel and Vehicle-Type Combinations with Those from Base-Case Petroleum-Fuel Vehicles}

Table 9 shows the base-case results for all the vehicle and fuel combinations considered here. Figure 2 shows the base-case results graphically for the full fuel cycle for LDVs; Fig. 3 shows them for HDVs. Figure 4 shows the base-case results for a fleet of HDVs and LDVs combined, using the VMT weighting factors of Table B.4. Figure 5 shows the base-case emissions from vehicle end use only (i.e., all upstream emissions are excluded).

\subsubsection{Standard Gasoline}

This andysis indicates that the use of reformulated gasoline would result in essentially the same fuel-cycle $\mathrm{CO}_{2}$-equivalent emissions as the use of standard, nonreformulated gasoline. As shown in Table 9, reformulated gasoline would produce only $1 \%$ more total fuel-cycle, $\mathrm{CO}_{2}$-equivalent emissions than would standard gasoline, a difference that is less than the uncertainty in the calculation. Consequently, the results throughout this report can be viewed as applying to any kind of gasoline, although I use reformulated gasoline for the reference case.

The reason reformulated gasoline and standard gasoline give essentially the same result is because of counterbalancing factors. Reformulated gasoline takes considerably more energy to make than does standard gasoline, a factor that, by itself, would increase fuel-cycle greenhouse gas emissions by $3 \%$. However, reformulated gasoline contains less carbon per Btu than does standard gasoline, a facror that would result in $1.5 \%$ lower total fuel-cycle, $\mathrm{CO}_{2}$-equivalent $\mathrm{g} / \mathrm{mi}$ emissions. Reformulated gasoline also produces less NMOC and CO from the tailpipe, and this would reduce fuel-cycle greenhouse gas emissions by $0.5 \%$. Thus, the increase in amissions due to extra refining energy (3\%) would be slightly greater than the decrease dut to the lower carbon content and tailpipe emissions $(1.5 \%+$ $0.5 \%=2.0 \%$ ).

Table 9 shows that the recovery and transport of crude oil would result in a slightly greater amount of emissions when standard gasoline is used than when reformulated gasoline is used. This result occurs because reformulated gasoline requires less crude oil than does standard gasoline, since methyl tertiary butyl ether (MTBE) has displaced some of the crude. Here, all emissions from MTBE manufacture are included under "fuel production." 


\begin{tabular}{|c|c|c|c|c|c|}
\hline & 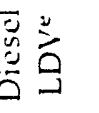 & 귱 & 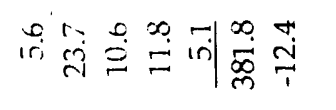 & 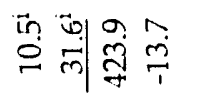 & \\
\hline $\begin{array}{ll}E \\
5 \\
0 \\
0 \\
0\end{array}$ & 主 & 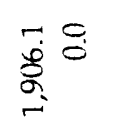 & 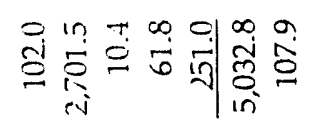 & 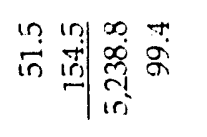 & \\
\hline 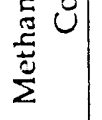 & 亥 & 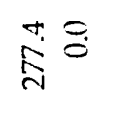 & 붐 & 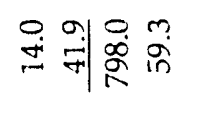 & in \\
\hline \begin{tabular}{ll}
$E$ & \multicolumn{1}{c}{} \\
0 & 0 \\
0 & 0
\end{tabular} & 总 & $\begin{array}{l}1 \\
\substack{0 \\
0 \\
i} \\
i=\end{array}$ & 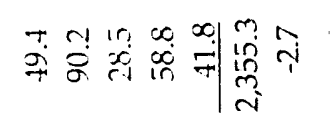 & 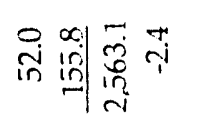 & \\
\hline$\Xi \tilde{Z}$ & 总 & 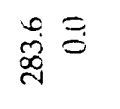 & 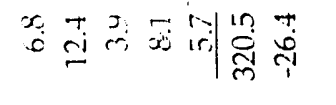 & 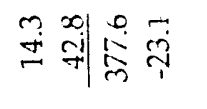 & 余量 \\
\hline U & 总 & 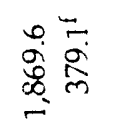 & 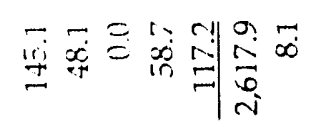 & 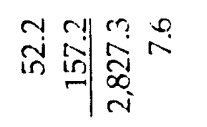 & \\
\hline & อ & 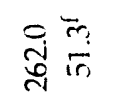 & 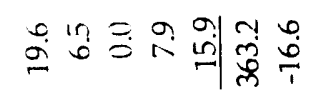 & 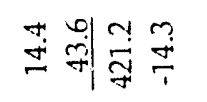 & $\begin{array}{l}0 \\
\text { inं } \\
\text { in }\end{array}$ \\
\hline$u$ & 主 & 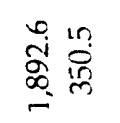 & 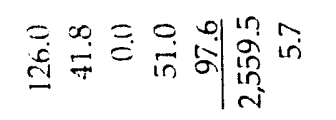 & 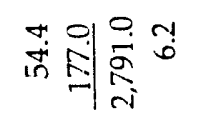 & \\
\hline$u$ & 方 & 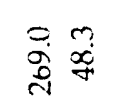 & 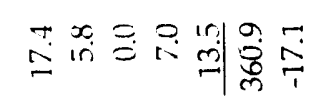 & \begin{tabular}{l}
0 \\
\multirow{2}{*}{}
\end{tabular} & $\begin{array}{l}\text { तु } \\
\text { in } \\
\text { in }\end{array}$ \\
\hline E & 主 & 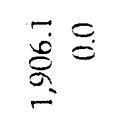 & 它 & 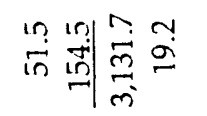 & \\
\hline 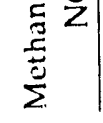 & 方 & 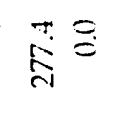 & 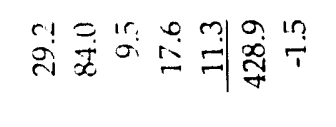 & 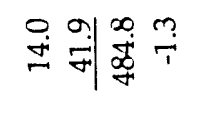 & क्षु \\
\hline & 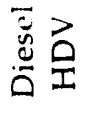 & $\begin{array}{l}\bar{i} \\
\text { i⿱ } \\
\text { i }\end{array}$ & 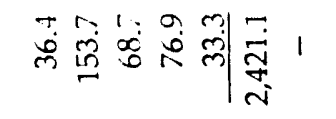 & 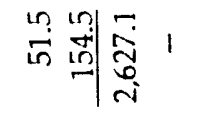 & \\
\hline & 它主 & 旾 & 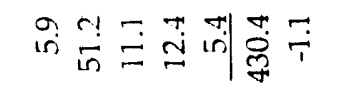 & 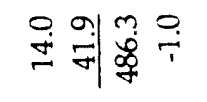 & $\underset{+\infty}{+\infty} 1$ \\
\hline 론 & 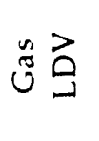 & $\hat{\overrightarrow{ల ్ ల}}$ & 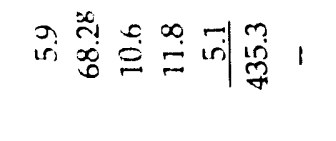 & 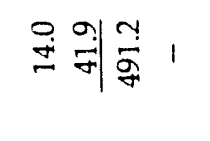 & $\frac{\pi}{\sigma} 1$ \\
\hline & 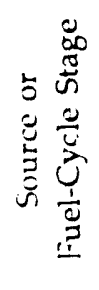 & 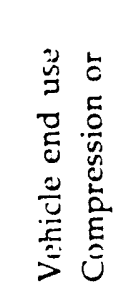 & 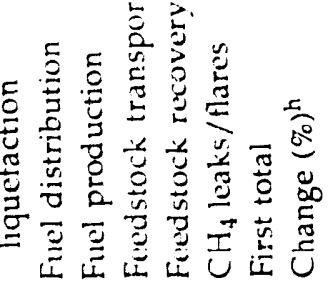 & 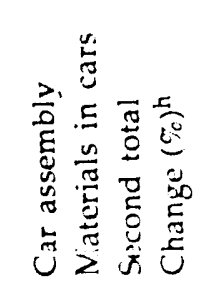 & 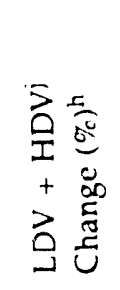 \\
\hline
\end{tabular}




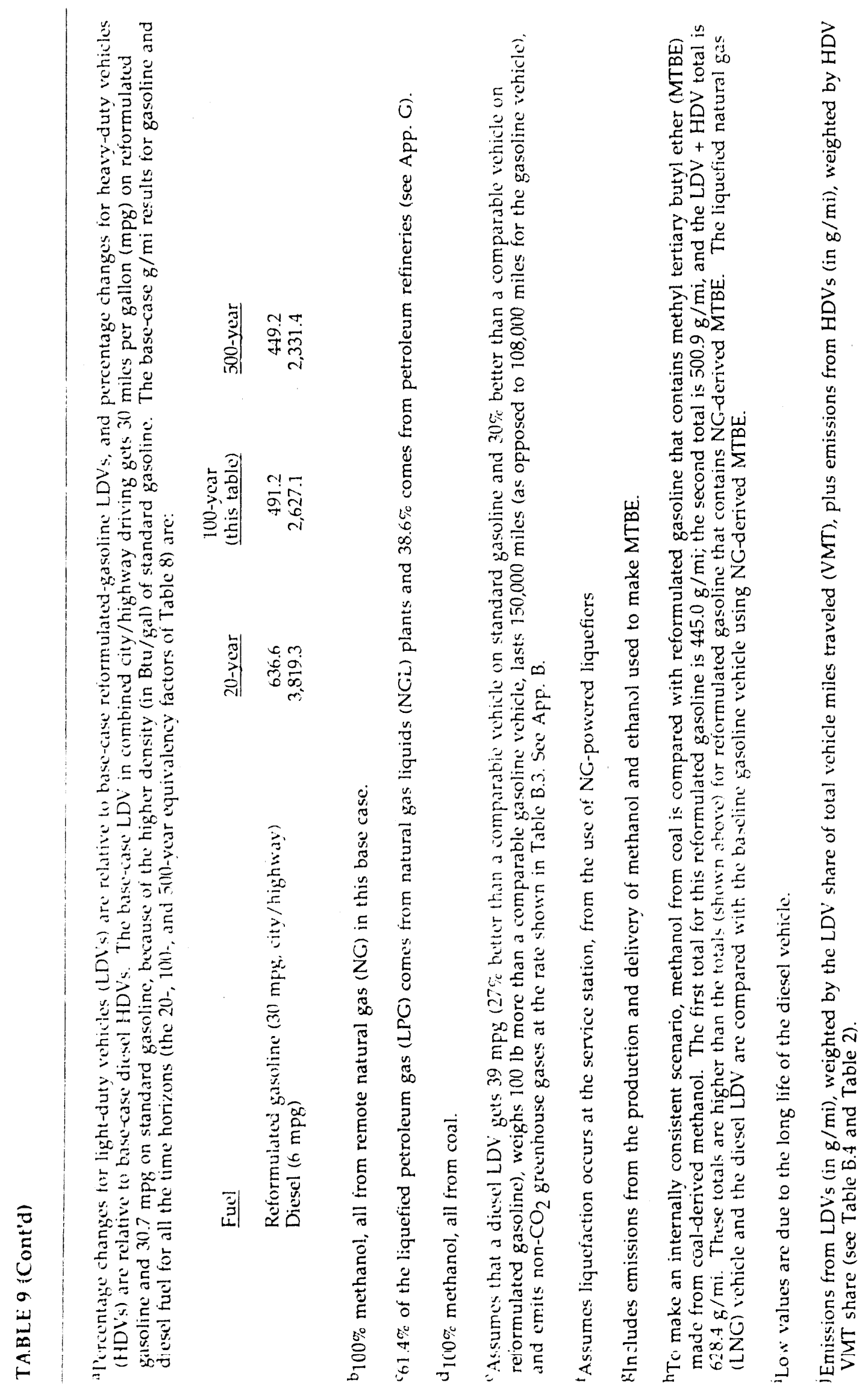




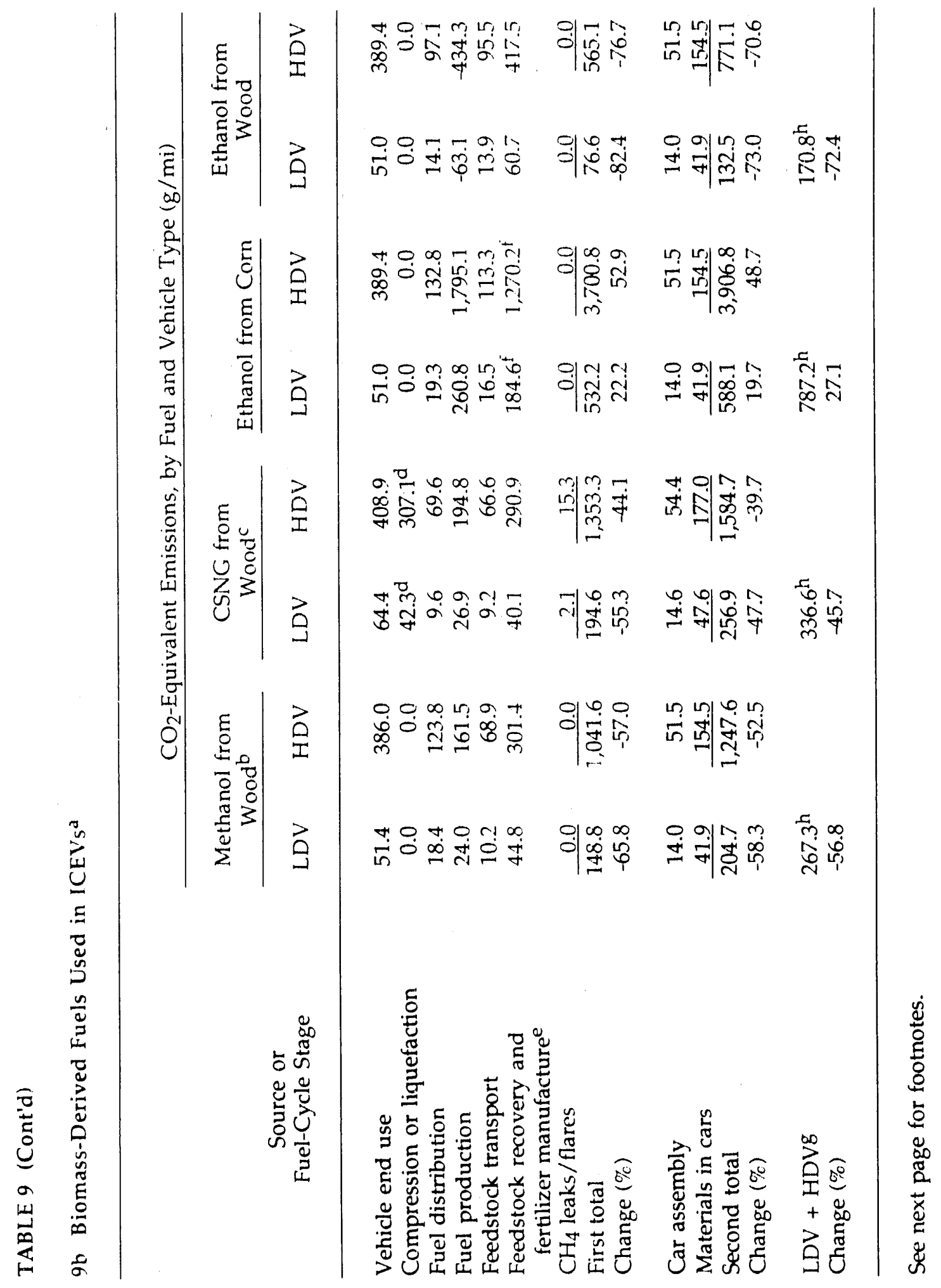




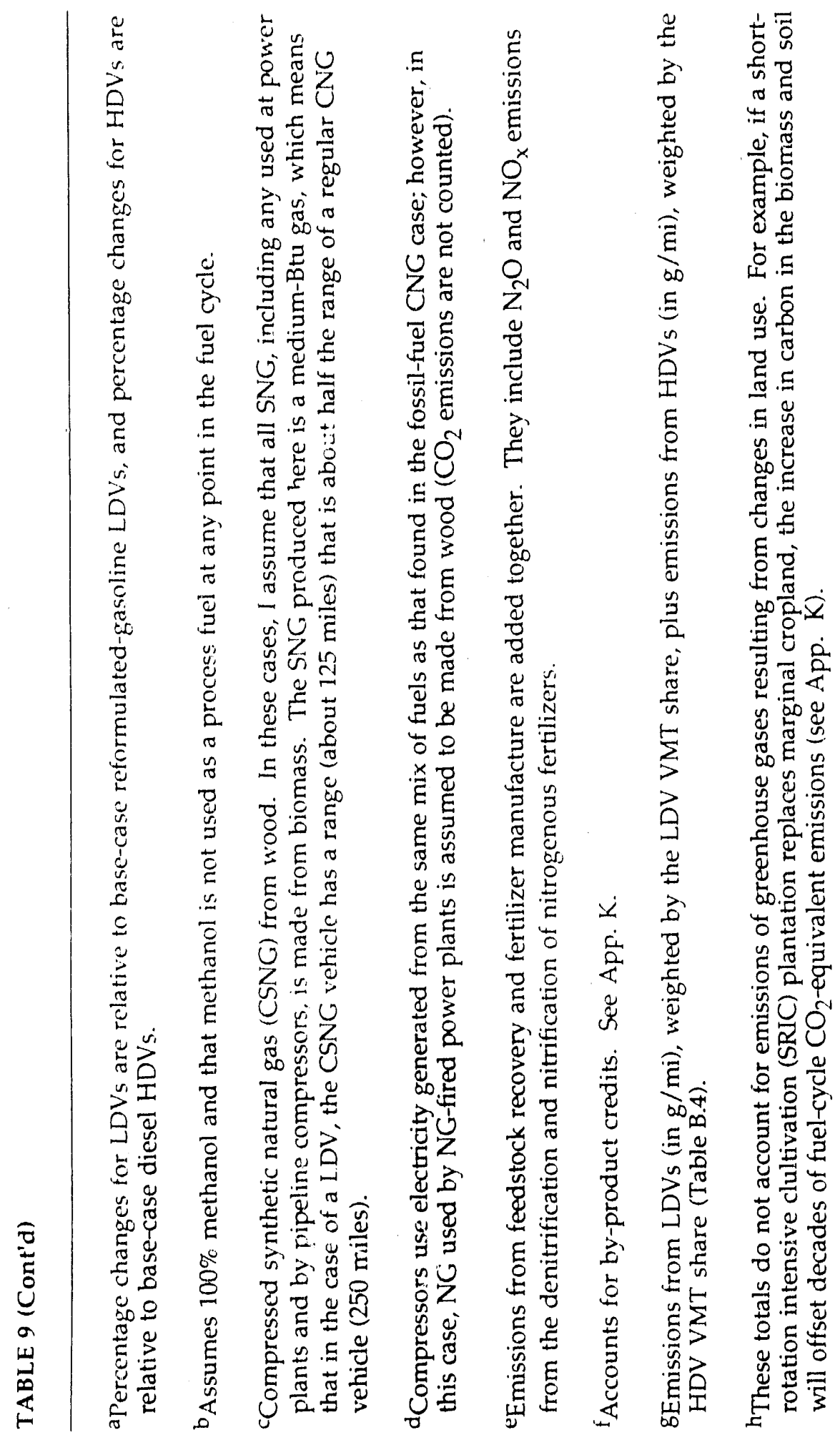




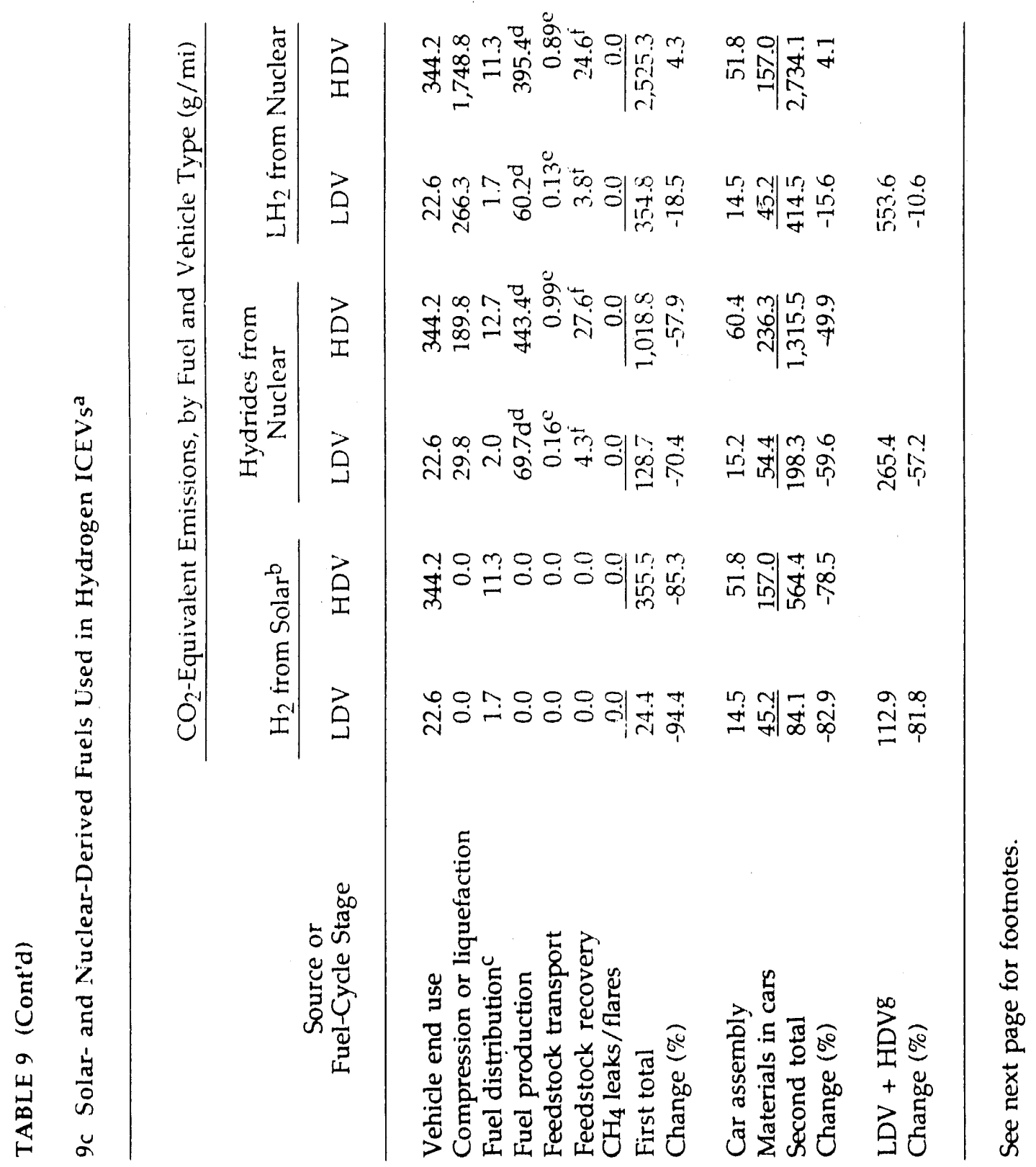




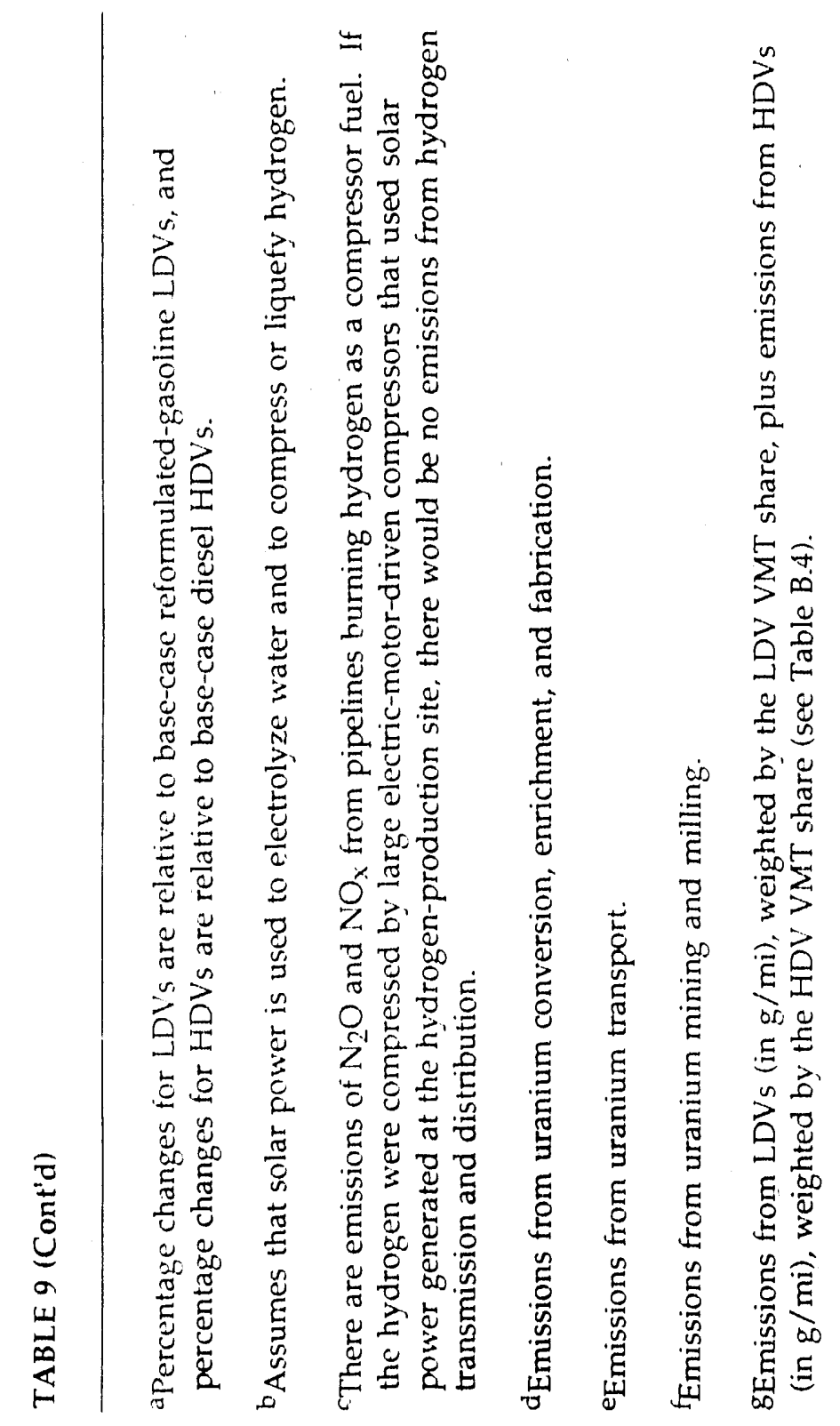




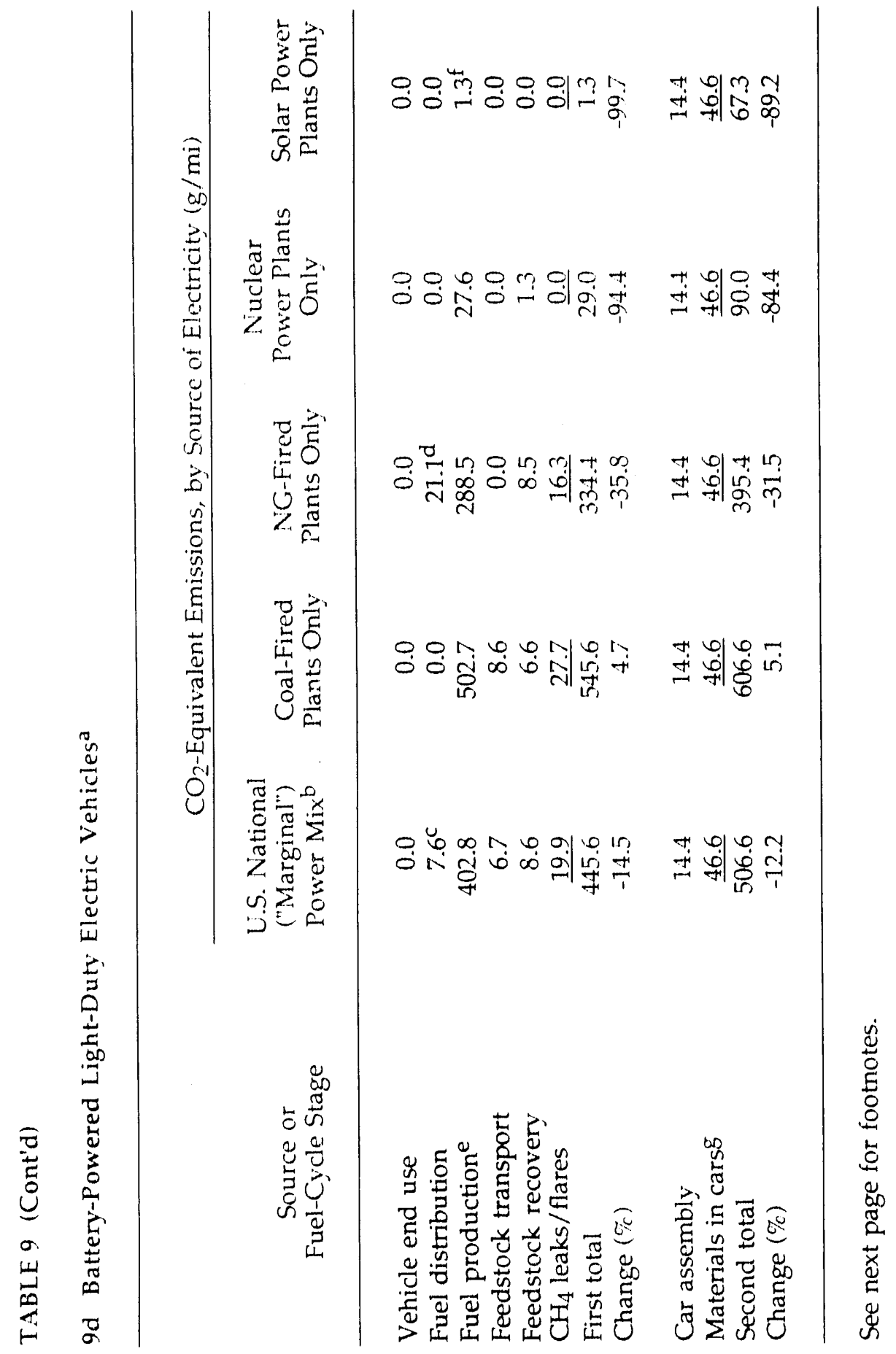




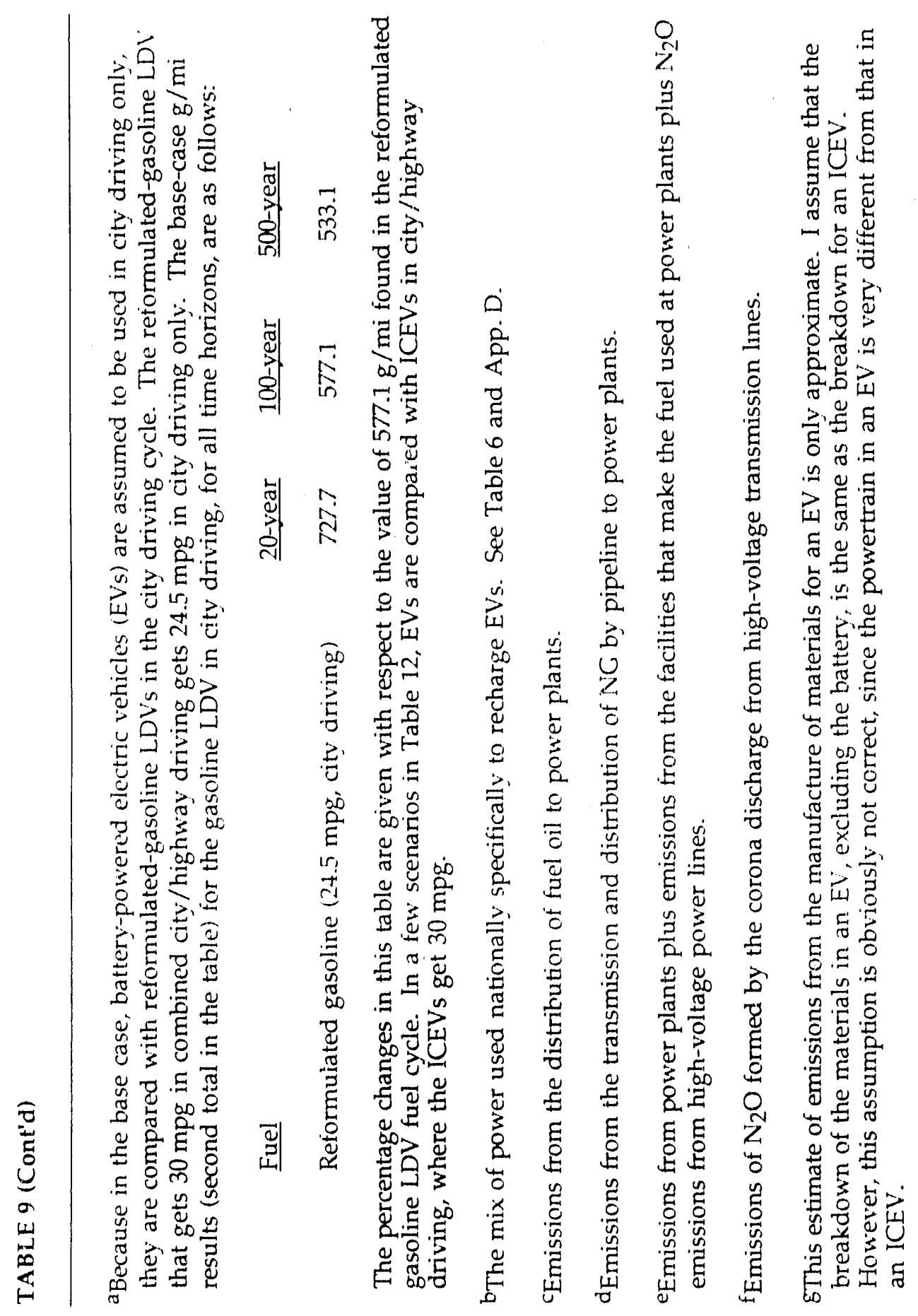




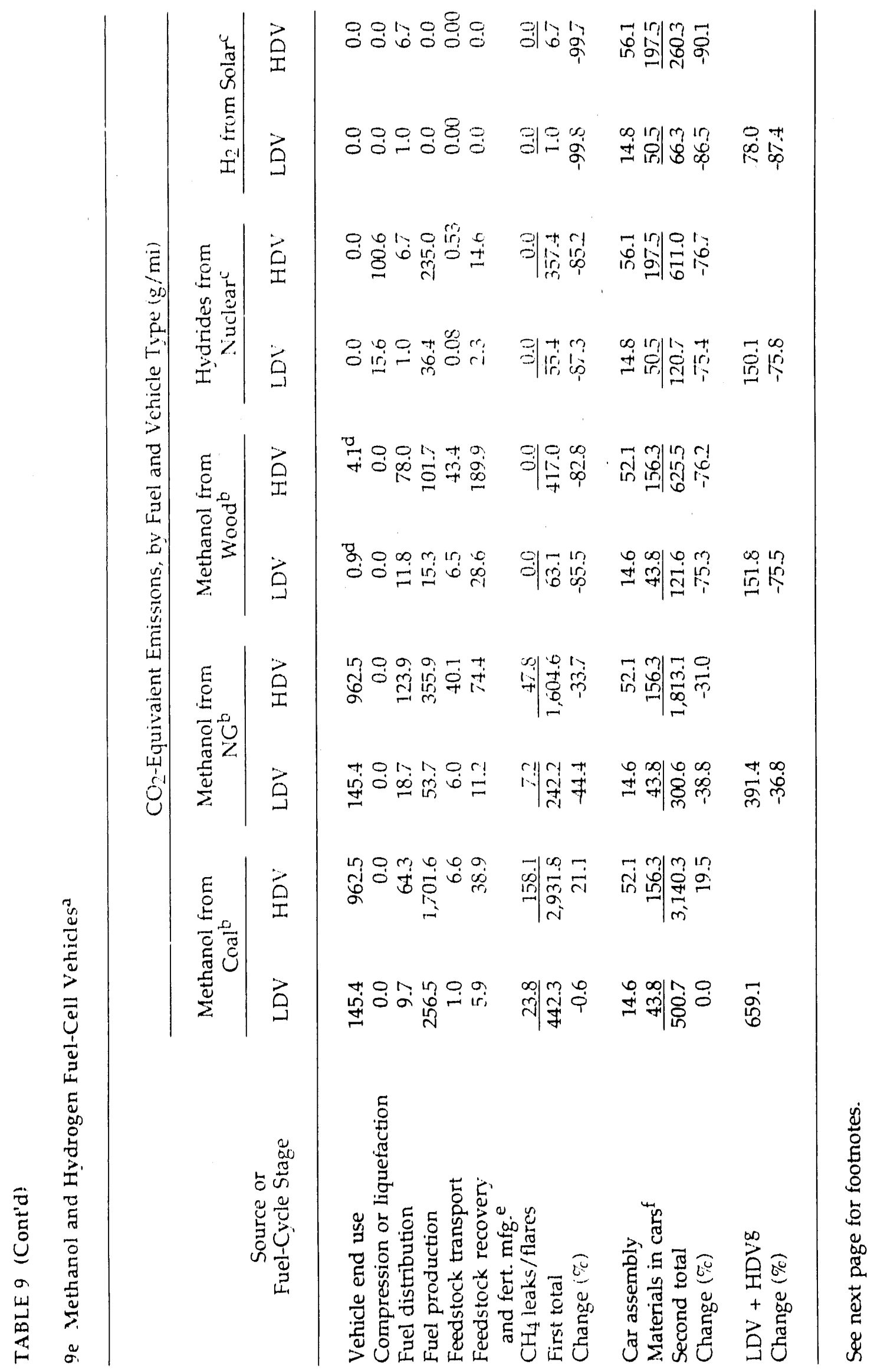




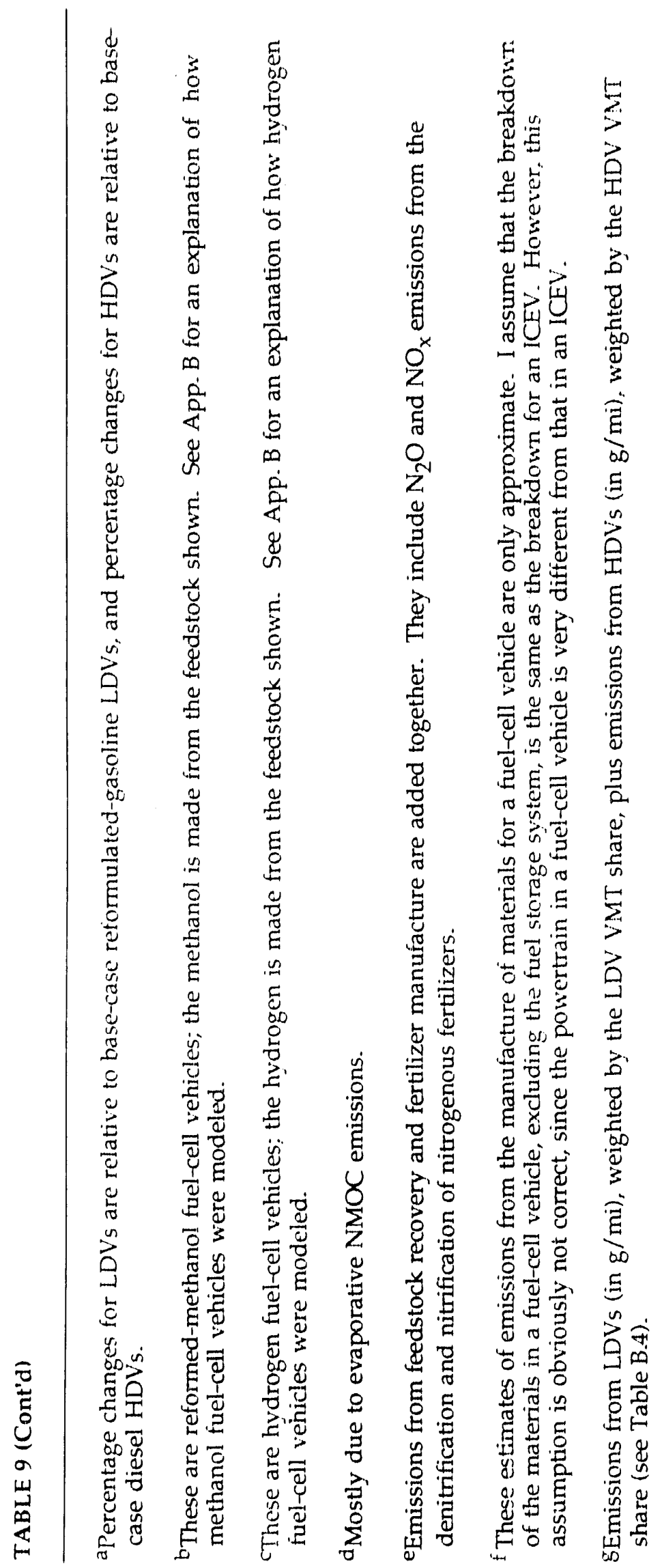




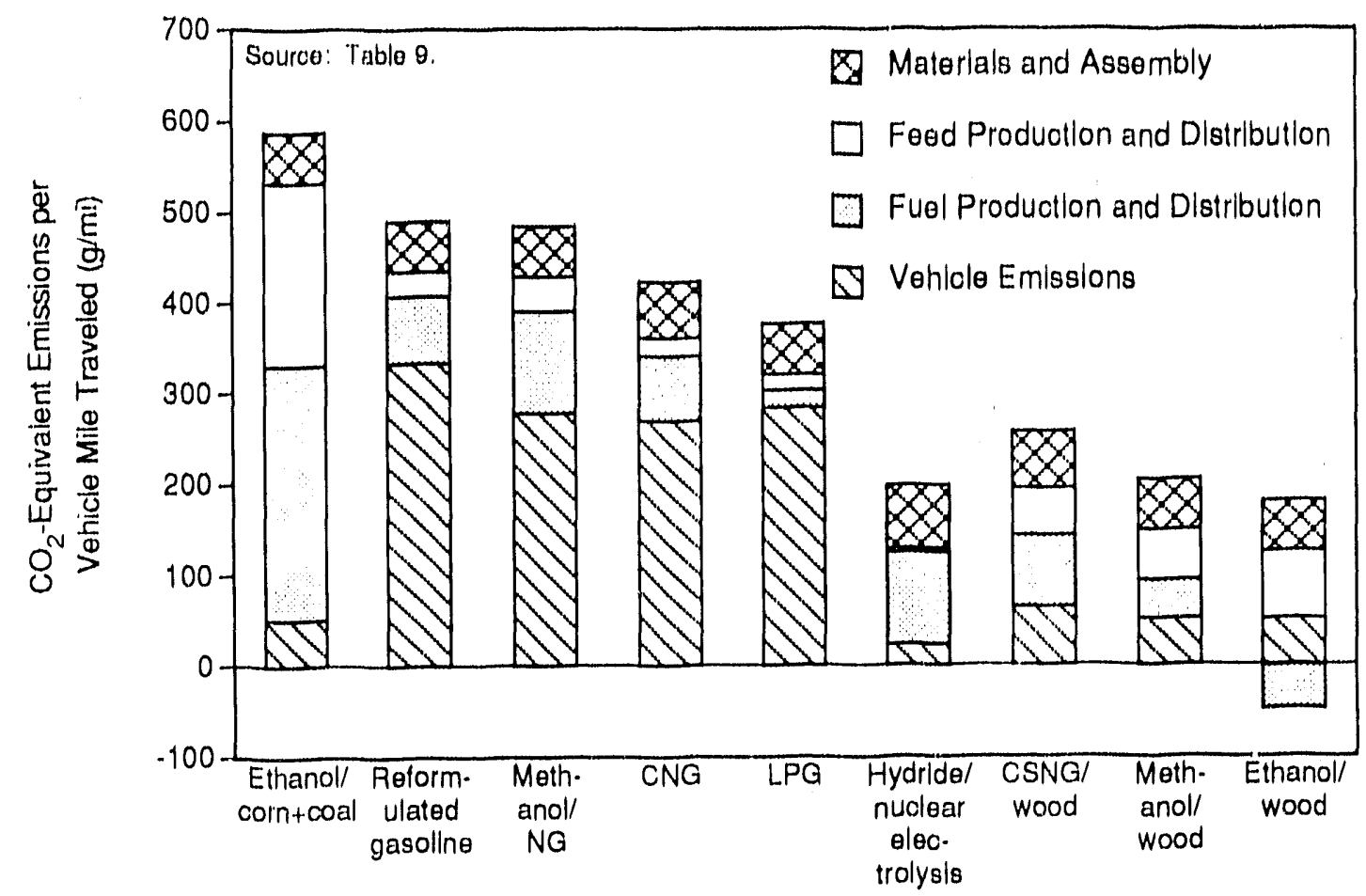

FIGURE 2 Total Fuel-Cycle, $\mathrm{CO}_{2}$-Equivalent Emissions for Light-Duty Vehicles

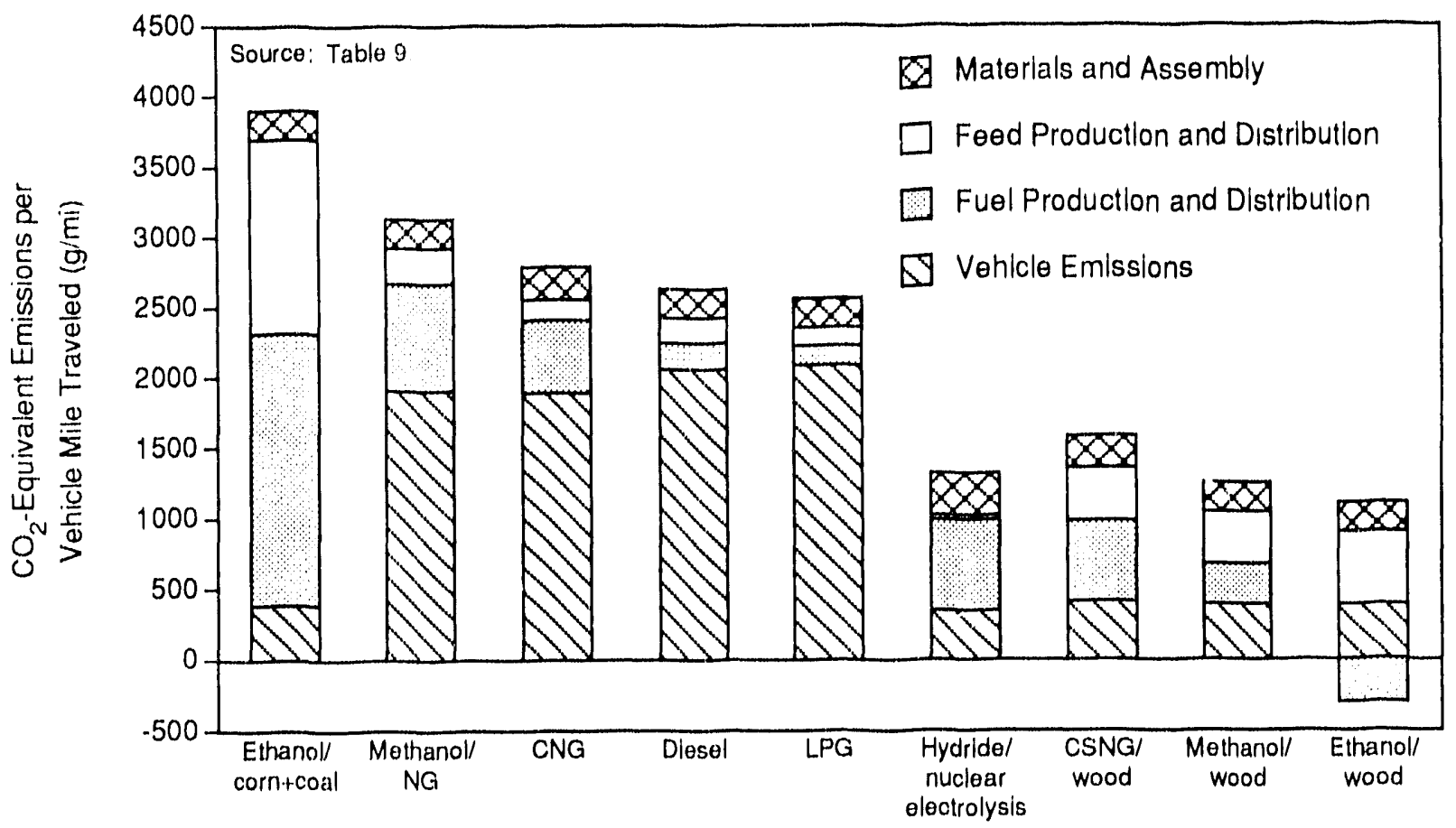

FIGURE 3 Total Fuel-Cycle, $\mathrm{CO}_{2}$-Equivalent Emissions for Heavy-Duty Vehicles 


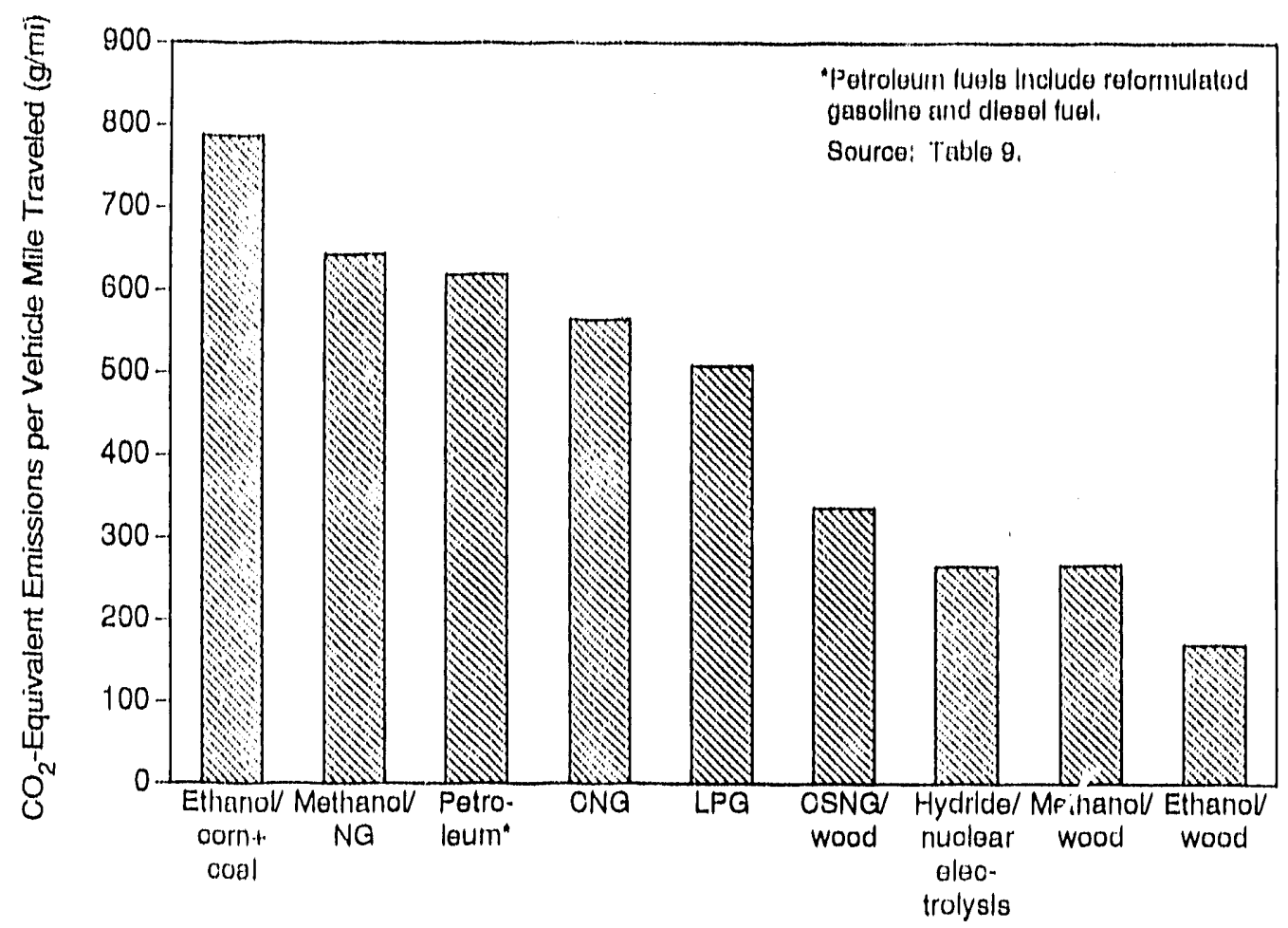

FIGURE 4 Total Fuel-Cycle, $\mathrm{CO}_{2}$-Equivalent Emissions for a Fleet of LightDuty and Heavy-Duty Vehicles Combined

\subsubsection{Diesel Light-Duty Vehicles}

Diesel-powered I.DVs, using low-sulfur diesel fuel, would produce 10-15\% less total fuel-cycle, greenhouse gas emissions than comparable spark-ignition vehicles using reformulated gasoline. Of interest is the fact that the bulk of this reduction would not be a result of the greater fuel economy of the diesel vehicle $(39 \mathrm{mpg}$ versus $30 \mathrm{mpg}$ on reformulated gasoline and $30.7 \mathrm{mpg}$ on standard gasoline) but rather of the lower energy requirement for diesel manufacture and the longer life of diesel vehicles. The lower refinery energy requirement would substantially reduce emissions from diesel refining (compared with gasoline refining), and the longer life of the diesel vehicle would reduce emissions resulting from the manufacture of materials and vehicles (compared with making gasoline LDVs). The greater fuel economy of diesel vehicles tends to reduce tailpipe $\mathrm{CO}_{2}$ emissions, but this benefit would be somewhat offset by their higher tailpipe $\mathrm{NO}_{\mathrm{x}}$ emissions and the higher carbon content of diesel fuel.

When compared with the standard gasoline fuel LDV cycle, the greater fuel economy of diesel I.DVs would also reduce upstream emissions from crude oil recovery and transport, because less crude would have to be recovered and moved to provide a mile's worth of fuel. However, the diesel fuel cycle does not enjoy this 


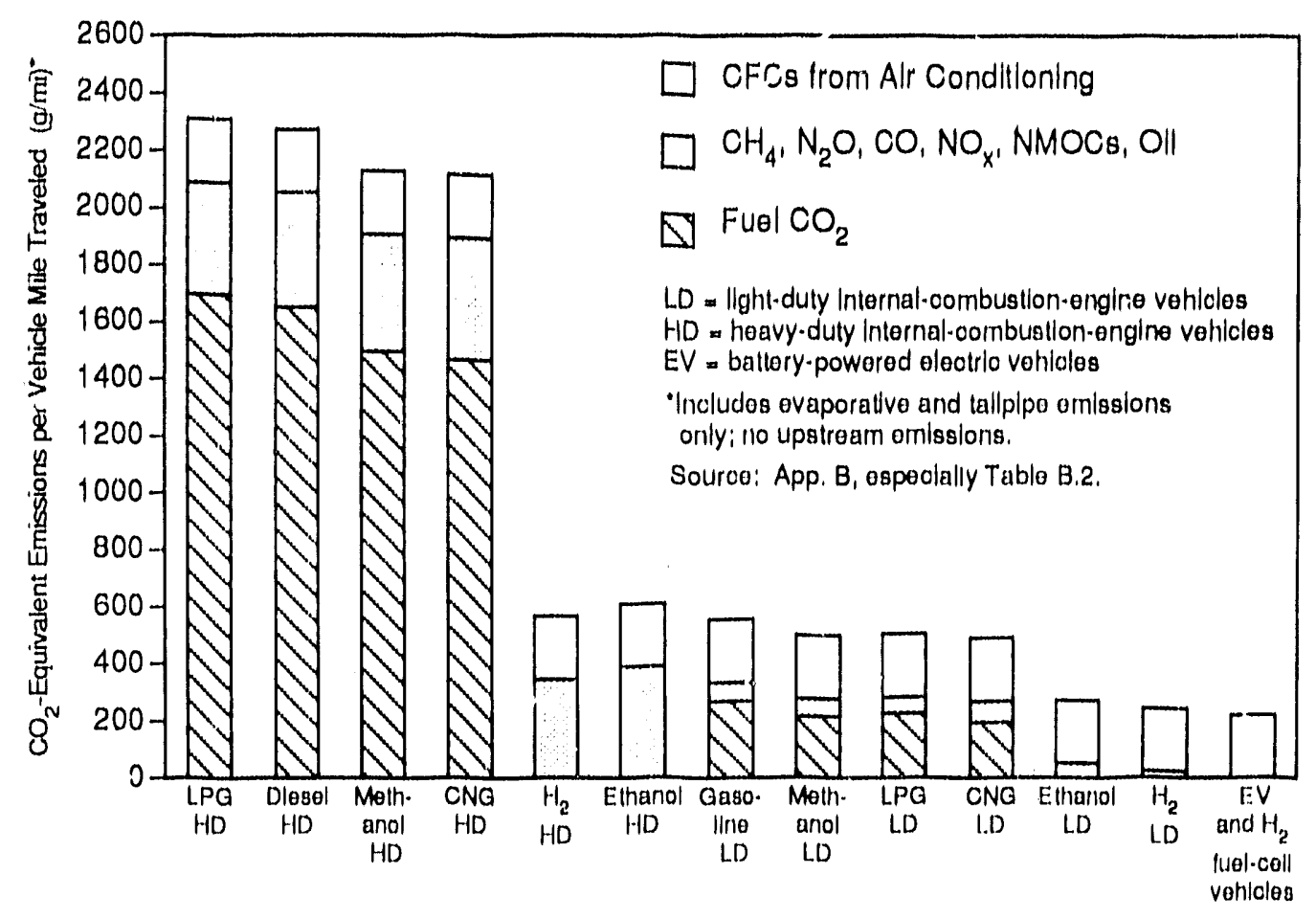

FIGURE $5 \mathrm{CO}_{2}$-Equivalent Emissions from Vehicle End Use Only

advantage over the reformulated gasoline LDV fuel cycle, because the upstream emissions reduction that would result from the greater fuel economy of diesel LDVs would be about the same as the reduction that would result from replacing some crude oil with MTBE. A comparison of upstream crude recovery and transport emissions from reformulated gasoline with upstream emissions from low-sulfur diesel fuel will confirm this conclusion.

In the United States today, few LDVs use diesel fuel. In 1988, U.S. households bought only 1.1 billion gallons of diesel fuel, scarcely more than $1 \%$ of the amount of gasoline bought (EIA, Houschold Vehicles Energy Consumption 1988, 1990). However, diesel's share of the LDV market is much higher in Europe and may grow in the United States.

\subsubsection{Natural-Gas-Derived-Methanol Vehicles}

Methanol LDVs, using 100\% methanol (M100) derived mainly from remote $\mathrm{NG}$, would emit roughly the same amount of greenhouse gases over the whole fuel cycle as would year-200() gasoline vehicles. Methanol vehicles emit substantially less greenhouse gases from the tailpipe than do gasoline vehicles because of their greater thermal efficiency and the lower carbon content of methanol. However, the production of methanol is less energy efficient than the production of gasoline and 
produces more greenhouse gas emissions. Moreover, the greater feedstock requirements of methanol production mean that more feedstock must be recovered and transported per unit of fuel ultimately provided, which causes emissions from recovery and transport to be higher. Also, the $\mathrm{CO}_{2}$-equivalent emissions from gas leaks associated with the production and transmission of the NG used to make methanol exceed the $\mathrm{CO}_{2}$-equivalent emissions from the venting and flaring of gas associated with oil production.

Methanol HDVs would emit about 20\% more greenhouse gases per mile than diesel LDVs. Methanol fares worse when it is compared with diesel fuel than when it is compared with gasoline because methanol does not have a thermal efficiency advantage over diesel fuel, and because diesel fuel takes much less energy to produce and has a lower carbon/Btu content than does gasoline.

If methanol were to be used in both HDVs and LDVs, the combined greenhouse gas emissions from the methanol fleet would be slightly greater than those from the replaced petroleum fleet (under the base-case assumptions used here). This result would occur because methanol HDVs emit a much greater amount of greenhouse gases than do diesel HDVs. Even though HDVs account for less than $10 \%$ of total highway vehicle miles traveled (VMT), they emit several times more greesho ase gases per mile and hence contribute significantly to total fleet emissions of greenhouse gases.

\subsubsection{CNG and LNG Vehicles}

The use of CNG and LNG in LDVs would decrease emissions of greenhouse gases by $10-15 \%$. ING would actually be very slightly better than CNG, because LNG vehicles weigh less than CNG vehicles (LNG tanks are lighter than CNG tanks), LNG is slightly more thermally efficient than CNG, LNG tanks require less energy to make than do CNG tanks, and liquefaction produces only slightly more $\mathrm{CO}_{2}$ equivalent emissions than does compression. (Liquefaction requires more total ene:gy but uses NG as a fuel.) Emissions from gas production and transport would be higher in the LNG case, because LNG uses more of its "own" fuel -- NG -- for process energy, but this increase would be relatively minor.

In heavy-duty afplications, CNG and LNG would cause a 5-10\% increase in emissions of greenhouse gases (compared with diesel fuel). This increase would result from the much lower thermal elficiency of NG HDVs (compared with diesel HDVs) and the lower energy requirements of diesel production (compared with gasoline production). Consequently, a policy promoting NG use in both heavyduty and light-duty applications would be less beneficial than a policy promoting NG use in light-duty applications only -- if used in both applications, NG would result in only a $5-10 \%$ reduction in fuel-cycle greenhouse gas emissions, whicreas a $10-15 \%$ reduction would be achieved if it were used in light-duty applications alone. 


\subsubsection{LPG Vehicles}

Liquefied petroleum gas, consisting of $95 \%$ propane and $5 \%$ butane, offers a $20-25 \%$ reduction in emissions of greenhouse gas from LDVs (compared with gasoline). Moreover, the use of LPG in HDVs would actually decrease greenhouse gas emissions (compared with diesel fuel). The combined HDV-plus-LDV effect of an LPG policy would be a better-than-15\% reduction in fuel cycle emissions of greenhouse gases. The LPG fuel cycle would thus produce the least amount of greenhouse gases of all the fossil fuel cycles, including that of diesel fuel.

There are several reasons why LPG would result in such relatively large reductions in emissions of greenhouse gases. LPG has a lower carbon content than does gasoline, and LPG vehicles are more efficient than gasoline vehicles. LPG vehicles also emit less $\mathrm{CO}$, which is an indirect greenhouse gas. Although methanol, CNG, and LNG vehicles would offer similar benefits, their lower emissions would be largely offset by higher upstream emissions (compared with gasoline). By contrast, upstream emissions from the LPG fuel cycle are relatively low: it takes much less energy to liquefy propane than to compress or liquefy $\mathrm{CH}_{4}$, convert $\mathrm{NG}$ to methanol, or refine crude oil to gasoline, and there are no $\mathrm{CH}_{4}$ leaks from the distribution of LPG. Also, LPG tanks are lighter than CNG tanks and hence take less energy to make and are less of a drag on fuel economy.

Emissions from the use of LPG depend on the source of the LPG (refineries emit more greenhouse gases than do NGL plants), the efficiency of the LPG vehicle, and other factors. Variations in these factors are examined in Table 12 (which appears later).

Note that the range of results presented here is based on the assumption that the LPG is made of NGL extracted from wet NG or of propane and butane produced from refinery streams. The results do not apply to LPG made of propane produced by reforming NG, because the energy requirements of producing large amounts of propane from NG are not considered here.

\subsubsection{Coal-Derived-Methanol Vehicles}

The use of methanol from coal would cause a very large increase in per-mile emissions of greenhouse gases: about $70 \%$ for LDVs and 100\% for HDVs. The increase would primarily result from the very large amount of emissions generated by the coal-to-methanol facility itself, although the amount of emissions from coalbed $\mathrm{CH}_{4}$ is also large. (Emissions from feedstock transport and fue! distribution actually would be lower in the methanol-from-coal case than the rnethanol-from-NG case, because it takes less energy to transport coal than NG, and because it would take less energy to distribute methanol from domestic coal pients to domestic end users than from foreign gas plants to domestic end users.) There is no combination of assumptions about vehicle technology, conversion technology (including 
advanced technologies that coproduce methanol and electricity), or $\mathrm{CH}_{4}$ emissions that would alter this basic conclusion. Inevitably, the use of coal to make methanol would cause a substantial increase in per-mile emissions of greenhouse gases.

\subsubsection{Corn-Derived-Ethanol Vehicles}

The use of ethanol made from corn (by using coal as the process fuel) would cause an increase in greenhouse gas emissions of about $29 \%$, given the base-case assumptions used here. (However, there are many other reasonable sets of assumptions; some of these are examined in the scenario analyses of Table 12.) There are two sources in the corn-to-ethanol cycle that result in a large amount of emissions: the combustion of coal at the ethanol production facility and the use of fertilizers in corn farming. A coal-fired ethanol production facility emits large amounts of greenhouse gases because it consumes relatively large amounts of coal and electricity (in the Midwest, where ethanol is and would be made, most electricity is generated from coal). However, the use of more efficient conversion technologies or low- $\mathrm{CO}_{2}$-producing process fuels (such as residues from corn farming) could greatly reduce emissions from a corn-to-ethanol plant.

The corn field itseif appears to be the source of a large amount of greenhouse gases -- not so much because of direct or indirect energy use, but because nitrogencontaining fertilizers can denitrify to produce $\mathrm{N}_{2} \mathrm{O}$ or nitrify to produce $\mathrm{NO}_{x}$. In fact, these emissions by themselves swing the final result on the use of ethanol from slightly favorable to unfavorable (compared with the gasoline base case). However, $\mathrm{N}_{2} \mathrm{O}$ and $\mathrm{NO}_{x}$ emissions from the use of fertilizer have not been well characterized. The possibility that these emissions might be much less than assumed here is examined in Table 12 (which appears later).

\subsubsection{Wood-Derived-Biofuel Vehicles}

The use of wood-based biofuels -- methanol, ethanol, and SNG -- would offer large reductions in per-mile emissions of greenhouse gases when compared with petroleum-based (gasoline and diesel) fuels: approximately 45\% for SNG, 55\% for methanol, and $70 \%$ for ethanol. The reductions would ultimately result from the fact that $\mathrm{CO}_{2}$ emissions from the combustion of a biofuel are not a net emission (o) the atmosphere, because the carbon in the emitted $\mathrm{CO}_{2}$ originally came from the atmosphere, as $\mathrm{CO}_{2}$, via photosynthesis. This reduction would be found in two places: as greatly reduced $\mathrm{CO}_{2}$-equivalent emission from vehicle tailpipes and somewhat reduced emissions from fuel production facilities that use a part of the wood as a process fuel.

The use of biofuels would not entirely eliminate $\mathrm{CO}_{2}$-equivalent emissions (Table 9). There are severai reasons for this. First, emissions of non-CO2 gases, primarily from the vehicles themselves, would be substantial even after the CO, 
$\mathrm{NMOC}$, and $\mathrm{CH}_{4}$ emissions would be given a credit because they contain carbon that originally came from $\mathrm{CO}_{2}$ in the atmosphere. Second, fossil fuels would be used at several points of the wood-to-fuel cycle: to transport wood and wood-fuel products, generate electricity, make fertilizer, and so on. The use of fossil fuels always results in $\mathrm{CO}_{2}$ emissions. Third, $\mathrm{N}_{2} \mathrm{O}$ emissions from denitrification and $\mathrm{NO}_{x}$ emissions from nitrification of the fertilizers used on wood plantations could be substantial. (However, the data on these emissions are quite poor, and the assumptions embodied in the results of Table 9 are very uncertain.) In the scenario analyses of Table 12 (which appears later), I examine the effects of varying assumptions about fossil fuel and fertilizer use in wood-to-fuel cycles.

The importance of non- $\mathrm{CO}_{2}$ greenhouse-gas emissions in the biofuel cycle is demonstrated well in the 20-year case, which weights non- $\mathrm{CO}_{2}$ gases heavily. Biofuels offer much less of a reduction in the 20-year case than in the 100-year and 50 (1-year cases and, in fact, are relatively unimpressive.

The relatively small reduction in emissions that would result from using compressed synthetic natural gas (CSNG) from wood and the relatively large reduction that would result from using ethanol from wood are related to electricity generation and use. The compression of wood-derived SNG would require a fair amount of electricity, which would probably be generated, at least in part, from fossil fuels. This generation would produce greenhouse gases. On the other hand, ethanol-from-wood plants would probably produce more electricity than they would need, and they would sell the excess. This situation would result in an electricity-generating credit for ethanol.

\subsubsection{Electric Vehicles}

Emissions attributable to battery-powered electric-motor-driven vehicles, called electric vehicles or EVs, are a function of two key variables: the mix of fuels used to generate electricity and the efficiency (in $\mathrm{mi} / 10^{6} \mathrm{Btu}$ ) of the EV relative to the base-case gasoline ICEV. If the EVs were to use the estimated marginal power mix for recharging (see Table 6 and App. D), EVs would reduce total fuel-cycle, $\mathrm{CO}_{2}$-equivalent emissions by more than $10 \%$. For the base-case EV fuel cycle, the vast majority of greenhouse gas emissions come from power plants, primarily coalfired plants. There is also a surprisingly large emission of $\mathrm{CH}_{4}$ from coal mines. If EVs were recharged solely by electricity generated by coal-fired power plants, there would be a slight increase in total fuel-cycle, $\mathrm{CO}_{2}$-equivalent emissions (compared with a reformulated gasoline fuel cycle). The use of electricity generated by NGfired plants would result in a $30 \%$ reduction in emissions (compared with gasoline). The largest reductions would be obtained by using nuclear- or solar-generated electricity to recharge EVs; in fact, the use of solar power would eliminate all emissions except those arising from materials manufacture and vehicle assembly. 
The efficiency of the EV is a function of the powertrain technology and of how the vehicle is driven. Thus, emissions from the use of EVs depend on where, when, and how the vehicle is used. Table 12, which appears later in the document, shows the results for combinations of different values of these variables.

\subsubsection{Internal-Combusion-Engine Vehicles Powered by Nuclear-Made Hydrogen}

The use of nuclear power to electrolyze water to make hydrogen is an interesting case. If fossil-based electricity were used to liquefy hydrogen to obtain liquefied $\mathrm{H}_{2}\left(\mathrm{LH}_{2}\right)$ or compress the hydrogen to make hydrides, and if the hydrogen were used in an ICEV, there would be four sources of greenhouse gases, one of them emitting quite a large amount. First, hydrogen-powered ICEVs would emit $\mathrm{NO}_{x}$ and trace amounts of $\mathrm{HC}, \mathrm{CO}$, and $\mathrm{CO}_{2}$, which together would have a global warming potential equal to $5 \%$ of the $\mathrm{CO}_{2}$-equivalent emissions from the petroleumvehicle fuel cycle. Second, the production of nuclear electricity would produce greenhouse gases, mainly at the uranium-enrichment stage, which consumes a large amount of coal-derived electricity. These emissions would equal roughly $15 \%$ of emissions from the petroleum-vehicle fuel cycle (hydrogen LDVs compared with gasoline LDVs, or hydrogen HDVs compared with diesel HDVs). Third, emissions from the manufacture of materials and the assembly of vehicles would amount to about $15 \%$ of $\mathrm{CO}_{2}$-equivalent emissions from the petroleurn-vehicle fuel cycle. The final source of greenhouse gas emissions would be the electricity generation used to supply power to the hydrogen compressors or liquefiers. Compression of hydrogen to 500-750 psi (to make a hydride) does not require much power; hence, emissions resulting from compressing hydrogen would be less than 10\% of petroleum fuelcycle emissions. However, it takes a large amount of electricity to liquefy hydrogen, and the generation of this electricity can produce a huge amount of greenhouse gases. In fact, hydrogen liquefaction is so energy intensive that the use of hydrogen liquefied by power from fossil fuel power plants would cause only a modest decrease in emissions of greenhouse gases (compared with the base-case petroleum vehicle). This case demonstrates the importance of considering emissions from all processes related to the provision of a transportation fuel.

\subsubsection{Fuel-Cell and Internal-Combustion-Engine Vehicles Using Solar-Made Hydrogen}

The use of fuel-cell vehicles could greatly reduce emissions of greenhouse gases. Fuel cells, which convert the chemical energy in fuels to electricity, are roughly twice as efficient as internal combustion engines and produce virtually no non- $\mathrm{CO}_{2}$ greenhouse gases. The use of solar power to make and compress or liquefy hydrogen for electric-motor-driven fuel-cell vehicles would eliminate all greenhouse gas emissions except those associated with making vehicles, equipment, and the materiais for energy facilities. This resuli would be achieved because solar 
power plants and electric motors (using either a battery or a fuel cell) produce no greenhouse gases. If emissions from materials manufacture and vehicle assembly were included, the reduction in $\mathrm{CO}_{2}$-equivalent emissions (compared with petroleum-based vehicles) would be $85-90 \%$. If the solar-made hydrogen were used in an ICEV instead of a fuel-cell vehinge, the $\mathrm{NO}_{x}$ and trace organic emissions from the engine would be about $5 \%$ of the fuel/cycle emissions from a gasoline ICEV and would slightly reduce the benefit of isitig hydrogen. These cases assume that solar power is used to compress or liquefy hydrogen. The use of fossil electricity for this purpose would produce moderate (in the case of compression) to substantial (in the case of liquefaction) greenhouse gas emissions (see Table 12, which appears later).

\subsubsection{Fuel-Cell Vehicles Using Methanol}

A fuel-cell vehicle using reformed methanol made from NG would har about $40 \%$ lower total fuel-cycle, $\mathrm{CO}_{2}$-equivalent emissions than the comparable gasoline ICEV. A fuel cell could bring the level of greenhouse gas emissions from the use of coal-derived methanol down to the level of emissions from a gasoline ICEV. And a fuel-cell vehicle using biomass-derived methanol would have $75 \%$ lower emissions than a comparable gasoline ICEV. In fact, the biomethanol fuel-cell vehicle is the lowest-emitting liquid-fucl option available.

However, the lowest emitters of all the options are electric-motor-driven vehicles that use solar or nuclear energy, either as electricity or as hydrogen. The use of hydrogen-powered fuel-cell vehicles, like the use of solar-powered batteryoperated EVs, would eliminate all emissions of greenhouse gases other than those associated with materials manufacture and vehicle assembly.

Note that if they were to run on methanol from NG, fuel-cell LDVs would reduce greenhouse gas emissions more than would fuel-cell HDVs (compared with gasoline and diesel vehicles, respectively). However, if they were to run on biomass-derived methanol or solar hydrogen, fuel-cell HDVs would provide the greater reduction. This result would occur because relative $\mathrm{CO}_{2}$ emissions from the methanol fuel-cell vehicle are proportional to the relative efficiency of the fuel cell, and a fuel cell has a greater efficiency advantage over a light-duty spark-ignition engine than it has over a heavy-duty compression-ignition engine. This relative efficiency advantage is also true for hydrogen fuel-cell vehicles and biomethanol fuel-cell vehicles, but it is largely irrelevant, because greenhouse gas emissions from these fuel cycles are only weakly related to efficiency: the vehicles themselves emit no greenhouse gases (hydrogen combustion produces no $\mathrm{CO}_{2}$, and biomass combustion does not produce net $\mathrm{CO}_{2}$ ), and the upstream fuel processes emit very little. For the case of hydrogen and biomass fuel-cell vehicles, the bulk of the emissions would come from materials manufacture and vehicle assembly, and emissions from the manufacturing stage of LDV are a greater percentage of total emissions from the whole fuel cycle for IDV s than for HDVs. 


\subsubsection{Contribution of Individual Greenhouse Gas Emissions to Total Fuel-Cycle Emissions}

Table 10 shows the $\mathrm{g} / \mathrm{mi} \mathrm{CO}_{2}$-equivalent emissions of individual greenhouse gases that come from the vehicles themselves (tailpipe plus evaporative emissions) and from all upstream (nonvehicular) processes. (Figure 4 showed $\mathrm{CO}_{2}$-equivalent emissions from vehicle end use only.) Non- $\mathrm{CO}_{2}$ greenhouse gases account for $20-25 \%$ of the tota! $\mathrm{CO}_{2}$-equivalent emissions from vehicles using fossil fuels (considering just the vehicles themselves) and nearly $100 \%$ of total greenhouse gas emissions from vehicles using biofuels. Emissions of $\mathrm{CO}, \mathrm{NO}_{x}$, and $\mathrm{N}_{2} \mathrm{O}$ from vehicles are relatively important contributors to total emissions, and emissions of $\mathrm{CH}_{4}$ are not, except in the case of NG vehicles. 'This situation occurs because emissions of $\mathrm{CH}_{4}$ (in $\mathrm{g} / \mathrm{mi}$ ) are less than those of NMOCs, CO, and $\mathrm{NO}_{x}$ (Table B.2) and because the $\mathrm{CH}_{4}$-to- $\mathrm{CO}_{2}$ conversion factor is less than the $\mathrm{N}_{2} \mathrm{O}$-to- $\mathrm{CO}_{2}$ and $\mathrm{NO}_{x}$-to- $\mathrm{CO}_{2}$ conversion factors (Table 8). This large contribution of non- $\mathrm{CO}_{2}$ greenhouse gases to total emissions underscores the importance of accurately estimating emissions of all direct and indirect greenhouse gases and using appropriate $\mathrm{CO}_{2}$-equivalency factors.

Non- $\mathrm{CO}_{2}$ greenhouse gases account for $15-20 \%$ of total $\mathrm{CO}_{2}$-equivalent emissions from upstream fossil-fuel-based processes (Table 10). These gases constitute a much larger percentage of total emissions from biomass-based processes, because $\mathrm{N}_{2} \mathrm{O}$ and $\mathrm{NO}_{x}$ are emitted from the fertilizer used to grow the biomass. However, these fertilizer emissions need to be better documented.

Table 10 reveals some intelesting results. The first is that giving the production of ethanol from corn a "by-product credit" results in negative $\mathrm{CO}$ emissions from the production stage, because large amounts of $\mathrm{CO}$ are produced by the gasoline engines (used in the soybean farming) that are displaced by the by-product. (See the notes to Table 10 for additional explanation.) The second is that emissions of $\mathrm{NO}_{x}$ are surprisingly large in several upstream processes: the production of methanol, the generation of electricity for EVs, and the nitrification of fertilizer applied to corn and trees. However, there is a lot of uncertainty associated with the $\mathrm{NO}_{\mathrm{x}}$ emission factors for methanol production and fertilizer nitrification. A final point is that $\mathrm{CH}_{4}$ emissions from the generation of electricity for EVs, arising primarily from the venting of coal mines, exceed $\mathrm{CH}_{4}$ emissions from the $\mathrm{NG}$ system used to supply NG vehicles.

Overall, non- $\mathrm{CO}_{2}$ gases are least important (as a percentage of total fucl-cycle emissions) in the EV fuel cycle, because in this cycle, there are only two significant sources: coal-fired plants that emit $\mathrm{NO}_{x}$ and coal mines that emit $\mathrm{CH}_{4}$. Among fossil-based processes, the non- $\mathrm{CO}_{2}$ gases are most important in the NG vehicle's fuel cycle (because it emits a relatively large amount of $\mathrm{CH}_{4}$ and small amount of $\mathrm{CO}_{2}$ ). Among all fuel cycles, non- $\mathrm{CO}_{2}$ gases are most important in the biofuel cycles -- the wood-to-ethanol cycle in particular -- because these cycles produce very little $\mathrm{CO}_{2}$ perse. 


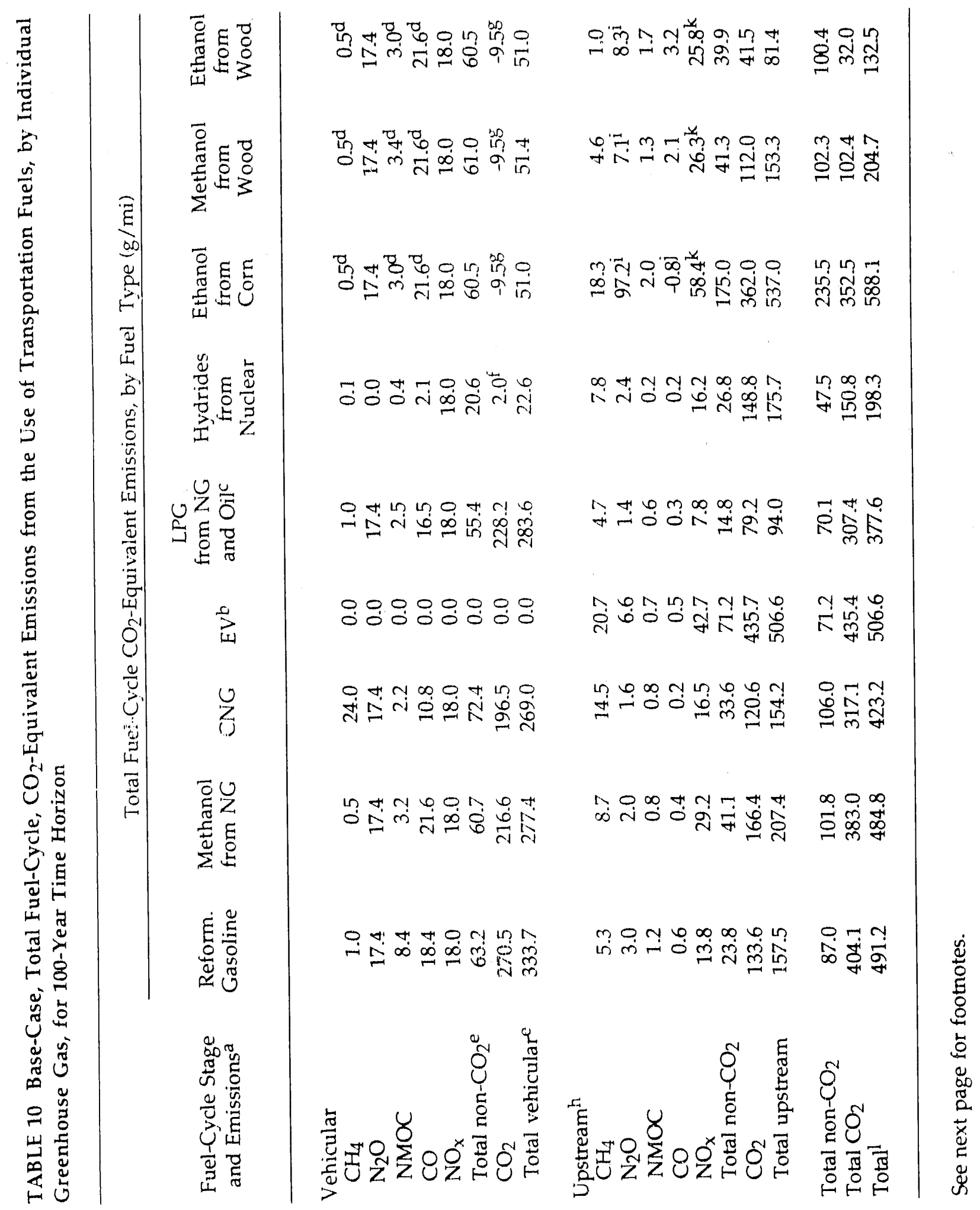




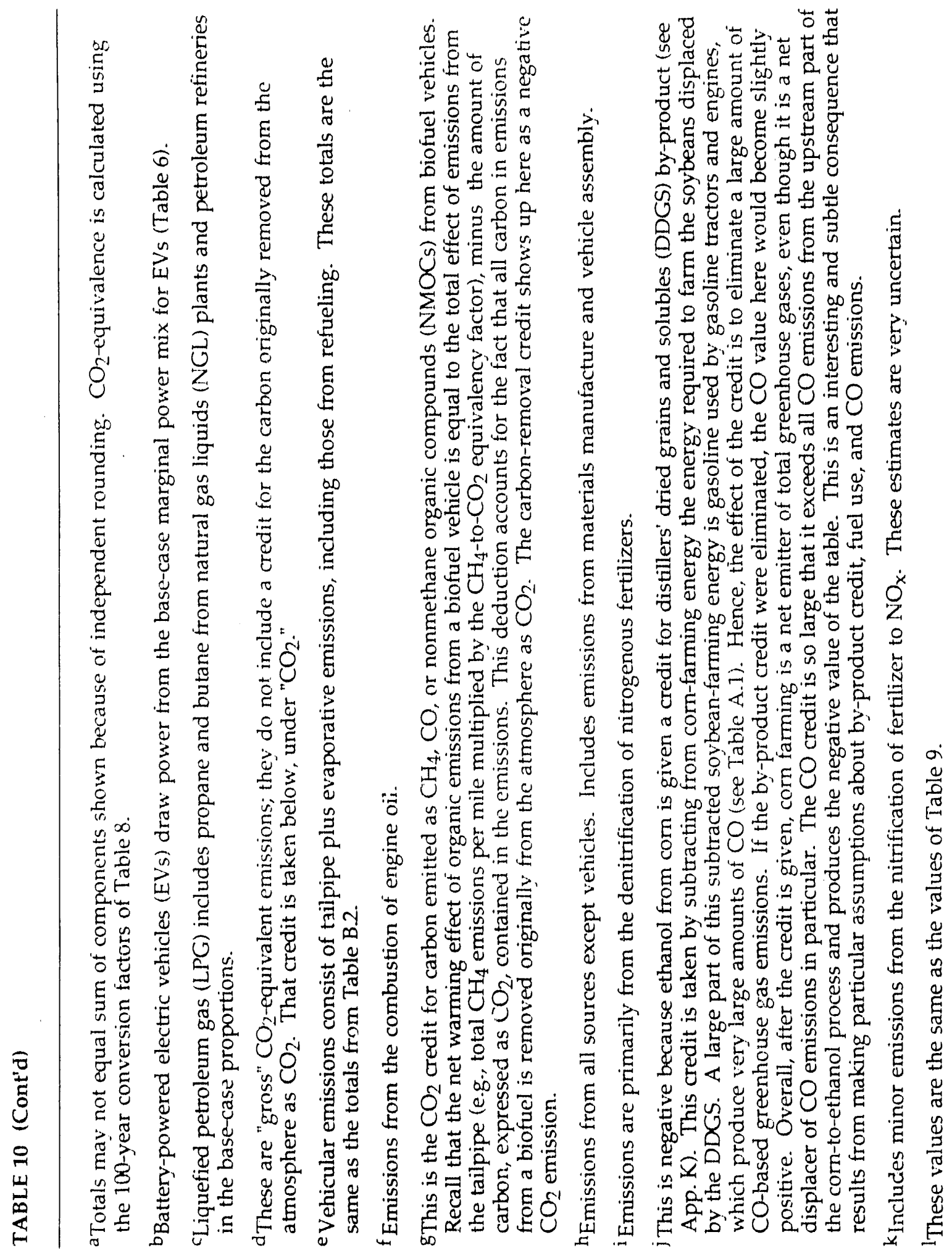




\subsubsection{Emissions as a Function of Fuel Economy}

Table 11 shows total fuel-cycle, $\mathrm{CO}_{2}$-equtvalent emissions as a function of the fuel economy (mpg) of the base-case gasoline vehicle. Total fuel-cycle emissions of $\mathrm{CO}_{2}$ only (i.e., not $\mathrm{NO}_{x}, \mathrm{CH}_{4}, \mathrm{NMOCs}, \mathrm{CO}$, and $\mathrm{N}_{2} \mathrm{O}$ ) are directly proportional to mpg. Total fuel-cycle, $\mathrm{CO}_{2}$-equivalent emissions of all gases, however, are not linearly proportional to mpg (except in the case of EVs), because $\mathrm{g} / \mathrm{mi}$ tallpipe cmissions of non- $\mathrm{CO}_{2}$ greenhouse gases are fairly independent of mpg. (Upstream ('vaporative emissions of NMOC are not independent of the mpg of the vehicle.) Thus, as shown in Table 11, increasing the fuel economy of ICEVs by a factor of two (from 20 to $40 \mathrm{mpg}$, for example) does not reduce total fuel-cycle, $\mathrm{CO}_{2}$-equivalent emissions by a factor of two. This nonproportionality is more pronounced if emissions from vehicle manufacture and assembly are included, because these emissions, although not fixed, are not directly proportional to fuel economy. (They are assumed here to be proportional to vehicle weight, but vehicle weight is not linearly related to fuel economy.)

In the case of EVs, however, the change in total fuel-cycle, $\mathrm{CO}_{2}$-equivalent emissions is directly proportional to the change in the efficiency $\left(\mathrm{mi} / 10^{6} \mathrm{Btu}\right)$ of the EV itself and "more than proportional" to the change in fuel economy of the basecase gasoline vehicle (in the sense, explained below, that increasing the mpg of the baseline ICEV by a factor of two reduces EV-cycle emissions by more than a factor of two). Emissions are proportional to the efficiency of the EV because power plant emissions are regulated per unit of fuel consumed. They are not proportional in the case of the gasoline vehicle, because ICEV emissions are regulated per mile of travel and hence independent of the rate of fuel consumption. The EV-cycle emissions are more than proportional to the fuel economy of the baseline ICEV because a $10 \%$ improvement in the mpg (or $\mathrm{mi} / 106 \mathrm{Btu}$ efficiency) of the ICEV translates into a greater than $10 \%$ improvement in the mi/10 Btu efficiency of the EV, which in turn results in an emissions reduction that is greater than $10 \%$. This situation occurs because of the interactive effect between the efficiency of the baseline ICEV and the weight of the EV battery: the increased baseline ICEV efficieicy reduces the size of the battery needed to provide a given driving range, which leads to a reduction in the weight of the EV, which increases the LV's efficiency, which reduces the size of battery needed, and so on. (Of course, the opposite occurs if the baseline ICEV becomes less efficient.) See App. B for a formal explanation of the calculation of EV energy use. 


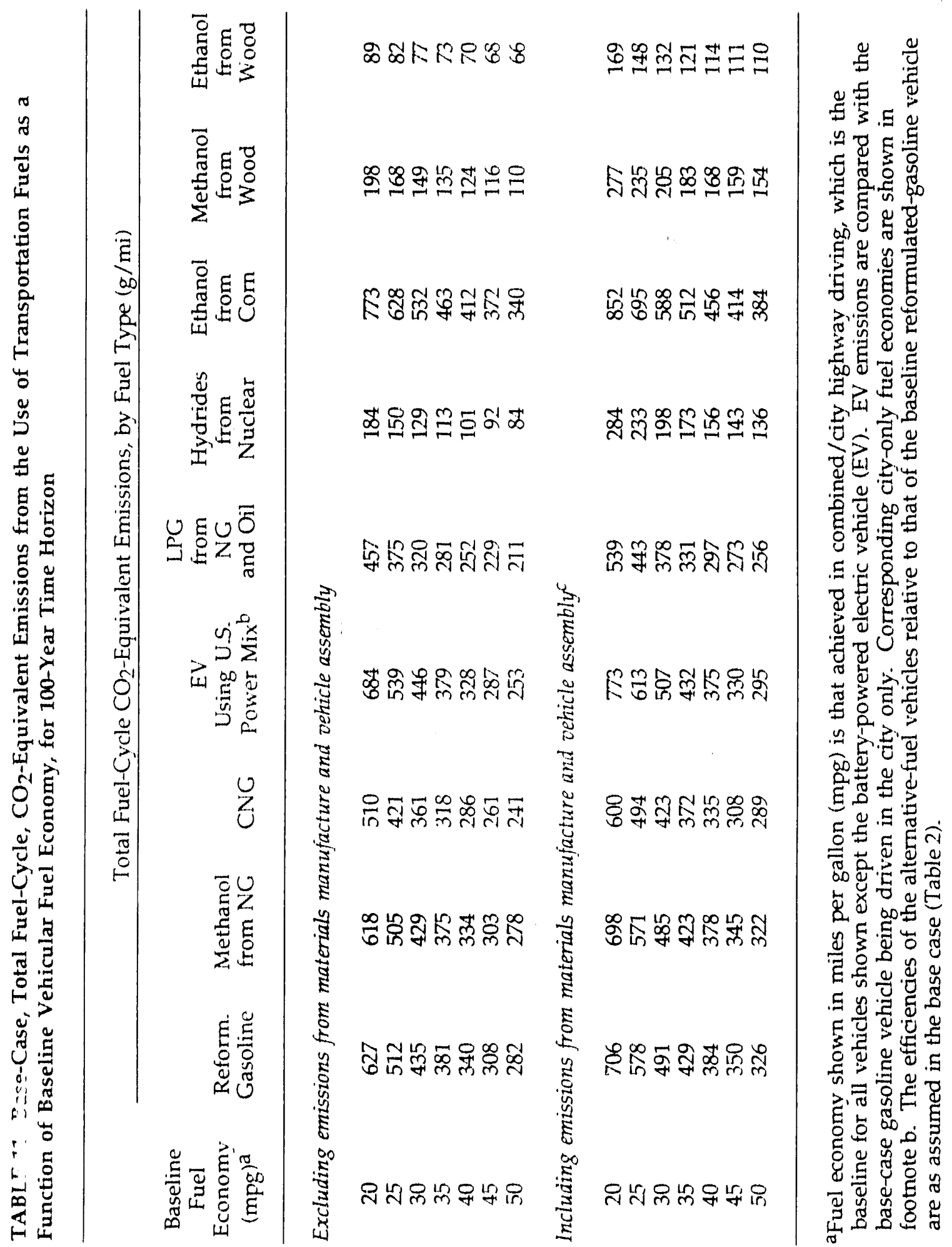




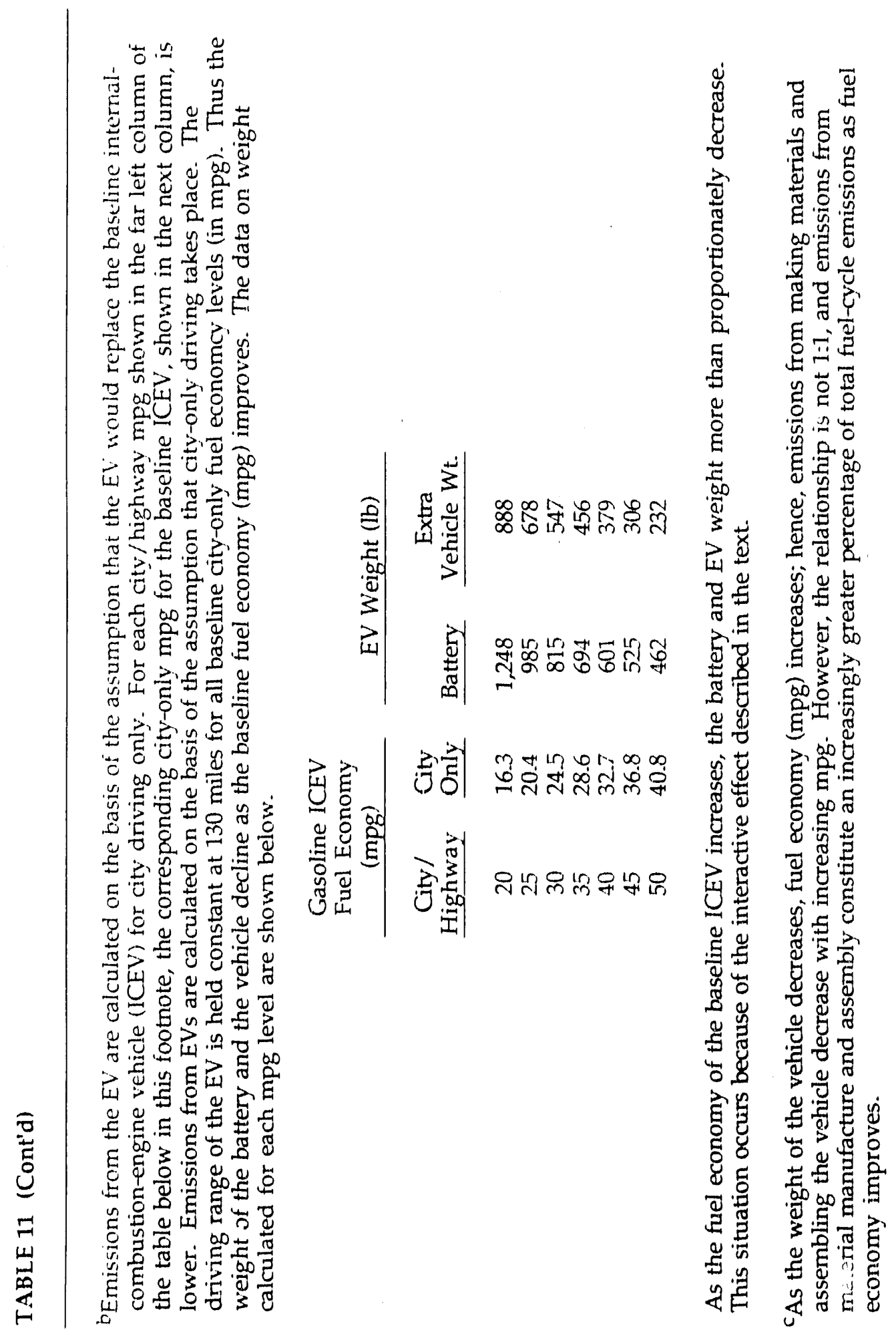




\section{SCENARIO ANALYSES}

The scenarios show how the assumptions about important input variables, if changed from their base-case values, could affect total fuel-cycle emissions under 20-year, 100-year, and 500-year time horizons. The scenario description column of Table 12 identifies all the variables that change for each scenaric. All other vartables (that is, all those not specifically mentioned in the scenario) retain their basc-case values. The table shows how much the total fuel-cycle, $\mathrm{CO}_{2}$-equivalent emissions in each scenario differ -. in percentage terms -- from those in the petroleum-fucl (gasoline or diesel fuel) baseline. A change of X\% means that, for the sconnrio described, total fuel-cycle emissions (in grams per mile) are equal to total fuel-cycle emissions from the petroleum-fuel baseline multiplied by $1+(X / 100)$. The gasoline or diesel-fuel baseline is different for different scenarios, depending on whether the changes described in the scenario affect the original petroleum-fuel base-case values (e.g., Tables 2-7). The petroleum-fuel baseline values are listed in the footnotes to Table 12. The results of the scenario analyses are summarized graphically in fings. 6 and 7 .

\subsection{SCENARIOS 1, 2, AND 3}

These scenarios recapitulate the results of Table 9 but also show results for the 20-year and 500-year time horizons. There are several noteworthy results. First, in most cases, the alternative fuels fare better than the petroleum fuels over longer time horizons; that is, they offer a bigger percentage reduction in total fuel-cycle, $\mathrm{CO}_{2}$ equivalent greenhouse gas emissions over 500 years than over 20 years. This result occurs because actual per-mile emissions of $\mathrm{CO}_{2}$ and differences among the alternatives in emissions of $\mathrm{CO}_{2}$ are constant regardless of the time horizon, whereas the $\mathrm{CO}_{2}$-equivalent of non- $\mathrm{CO}_{2}$ greenhouse gas emissions decreases as the time horizon lengthens. In other words, the difference (usually a reduction) in total emissions among the alternatives that is due to $\mathrm{CO}_{2}$ emissions alone "stands out" more (i.e., contributes to a larger percentage reduction) in long-term projections because it is seen against a smaller $\mathrm{CO}_{2}$ plus non- $\mathrm{CO}_{2}$ emissions total in the longer run. The differences among the alternatives in emissions of non- $\mathrm{CO}_{2}$ gases could change in such a way as to counter this resull, but this happens in only a few cases.

Second, for almost all fuels, the difference between the 20-year and 10()-year cases is greater than the difference between the 100-year and the 500-year cases, because the ratio of the 20-year to the 100-year conversion factors for emissions is greater than the ratio of the 100-year to the 500-year conversion factors, with the exception of the conversion factor for $\mathrm{N}_{2} \mathrm{O}$ (Table 8 ; CFC.s excluded). The $\mathrm{N}_{2} \mathrm{O}$ conversion factor has an interesting effect in the corn-to-ethanol case. Corn fitrming appears to produce large amounts of $\mathrm{N}_{2} \mathrm{O}$ and $\mathrm{NO}_{x}$ as a result of the denitrification and nitrification of fertilizer, respectively (App. N). These emissions accounl for a large portion of the total $\mathrm{CO}_{2}$-equivalent emissions from the corn-to-ethanol fuel 
TABLE 12 Comparison of Total Fuel-Cycle, $\mathrm{CO}_{2}$-Equivalent Emissions (measured in grams per mile) from the Use of Alternative Transportation Fuels with Emissions from the Lse of Bascline petroleum Fuels under Different Scenarios

P'ercentage Change

in Emissions from

Baseline Valuc,

by Time Horlzonb

Senario Number and Descripliond

$20 \mathrm{yr} \quad 10() \mathrm{yr} \quad 5(0) \mathrm{yr}$

1. Basci-case alternative-fucl LD ICEVs, EVs, and fucl-cell vehiclesc

Standard gasoline

Mothanol/NG

Methanol/coial

CNC;

LNG

Marginal U.S. mix/l:V

lithanol/corntecol

Hydride/nuclear electrolysis

$1 \mathrm{H}_{2} /$ muclear electrolysis

I.I' $\mathrm{C} /$ /oil and $\mathrm{NC}$

Methanol/wood

CSNCI/wod

lithanol/wood

llydrogen/all-soliar

All-solar/EV

Methanol/NG/fuel coll

Methanol/coal/fuel cell

Methanol/wood/fuel cell

Ilydride/nuclear electrolysis/fuel cell

Hydrogen/all-solar/fucl coli

$\begin{array}{rrr} & -1.0 & \\ 5.8 & -1.3 & -3.6 \\ & 59.3 & \\ -2.1 & -13.8 & -18.1 \\ & -14.3 & \\ -7.9 & -12.6 & -12.8 \\ .37 .0 & 19.7 & 6.7 \\ -50.5 & -59.6 & -62.2 \\ & -15.6 & \\ -23.0 & -23.1 & -23.4 \\ -40.7 & -58.3 & -65.6 .6 \\ -21.8 & -47.7 & -57.7 \\ -53.4 & -73.0 & -81.3 \\ & -82.9 & \\ & -89.2 & \\ -40.9 & -38.8 & -37.2 \\ & -0.0 & \\ -70.6 & -75.3 & -76.8 \\ -74.4 & -75.4 & -75.5 \\ & -86.5 & \\ & & \end{array}$

2. Base-case alternative-fuel HD ICEVs and fuel-cell vehiclese

Methanol/NG

Methanol/coal

ING

Ethanol/corntcoal

Hydride/nuclear electrolysis

$1 . \mathrm{H}_{2} /$ nuclear olectrolysis

L.P'G/oil and NG

Mothanol/wood

CSNG/ word

I:thanol/word

Ilydrogen/all-solar

Methanol/NG/fuel cell

Methanol/coal/fucl cell

Methanol/wood/fuel cell

Hydride/nuclear ciectrolysis/fucl coll

Hydrogen/all-solar/fucl coll

$24.2 \quad 19.2$

99.4

$13.7 \quad 6.2$

7.6

$62.3 \quad 48.7$

$-33.2-49.9$

17.3

3.2

33.4

$-56.7$

$\begin{array}{lll}-3.2 & -2.4 & -2.1\end{array}$

$\begin{array}{lll}-27.5 & -52.5 & -6.3 .0\end{array}$

$\begin{array}{lll}-9.9 & -39.7 & -52.2\end{array}$

$\begin{array}{lll}-4(0.8 & -70.6 & -83.3\end{array}$

$-78.5$

$\begin{array}{lll}-41.3 & -31.0 & -26.8\end{array}$

$\begin{array}{lll}-74.0 & -76.2 & -77.4\end{array}$

$\begin{array}{lll}-78.4 & -76.7 & -76.1\end{array}$

$-90.1$ 
Percentage Change in Emissions from

Baseline Value, by Time Horizon'

Scenario Number and Description ${ }^{a}$

$20 \mathrm{yr} \quad 100 \mathrm{yr} \quad 50() \mathrm{yr}$

3. Base-case alternative-fuel LD + HD ICEVs and fuel-cell vehicles ${ }^{c}$

Methanol/NG

Methanol/coal

$\begin{array}{rrr}10.9 & 3.9 & 1.6 \\ & 69.4 & \end{array}$

CNG

$\begin{array}{lll}2.3 & -8.7 & -12.8\end{array}$

LNG

Ethanol/corn+coal

$-8.7$

Hydride/nuclear electrolysis

$\mathrm{LH}_{2} /$ nuclear electrolysis

LPG/oil and NG

Methanol/wood

CSNG/wood

Ethanol/wood

Hydrogen/all-solar

Methanol/NG/fuel cell

Methanol/coal/fuel cell

Methanol/wood/fucl cell

Hydride/nuclear electrolysis/fuel cell

Hydrogen/all-solar/fuel cell

44.0 $\quad 27.1 \quad 13.4$

$\begin{array}{lll}-45.7 & -57.2 & -(6) .8\end{array}$

$\begin{array}{lll}-17.5 & -17.9 & -18.1\end{array}$

$\begin{array}{lll}-37.0) & -56.8 & -64.9\end{array}$

$\begin{array}{lll}-18.5 & -45.7 & -56.3\end{array}$

$\begin{array}{lll}-49.9 & -72.4 & -81.8\end{array}$

$-81.8$

$-41.0 \quad-36.8 \quad-34.6$

$\begin{array}{rrr} & 4.9 & \\ -71.6 & -75.5 & -76.9\end{array}$

$\begin{array}{lll}-75.5 & -75.8 & -75.6\end{array}$

$-87.4$

4. Base-case alternative-fuel LD ICEVs and EVs, $\mathrm{NO}_{x}$ excluded,

NMOCs oxidize only ( $3.66 \mathrm{CO}_{2}$-equivalency factor)

Methanol/NG

CNG

Marginal U.S. mix/EV

Ethanol/corn+coal

Hydride/nuclear electrolysis

LPG/oil and NG

Methanol/wood

CSNG/ wood

Ethanol/wood

$\begin{array}{rrr}-1.5 & -3.9 & -4.6 \\ -1.5 & -14.6 & -18.5 \\ -11.7 & -13.5 & -13.3 \\ 16.1 & 12.3 & 3.6 \\ -62.5 & -63.8 & -63.8 \\ -21.8 & -22.7 & -23.3 \\ -59.7 & -65.3 & -68.3 \\ -40.3 & -55.2 & -60.8 \\ -75.6 & -81.1 & -84.5\end{array}$

5. Base-case alternative-fuel HD ICEVs, $\mathrm{NO}_{x}$ excluded,

NMOCs oxidize only ( $3.66 \mathrm{CO}_{2}$-equivalency factor)

Methanol/NG

CNG

Ethanol/corn+coal

Hydride/nuclear electrolysis

LPG/oil and NG

Methanol/wood

$\begin{array}{lll}19.0 & 16.9 & 16.4\end{array}$

$\begin{array}{lll}17 .() & 5.8 & 2.9\end{array}$

$\begin{array}{lll}46.9 & 42.0 & 3(0 .)\end{array}$

$\begin{array}{lll}-57.2 & -59.6 & -60.5\end{array}$

CSNG/wood

$\begin{array}{lll}-2.0 & -2.0 & -1.9\end{array}$

$-63.3 \quad-67.0 \quad-68.8$

Ethanol/wood

$\begin{array}{lll}-42.4 & -54.0 & -58.1\end{array}$

$\begin{array}{lll}-85.8 & -88.6 & -9(1.5\end{array}$ 
TABLE 12 (Cont'd)

Percentage Change in Emissions from

Baseline Value, by Time Horizon ${ }^{i}$

Scenario Number and Description ${ }^{a}$

$20 \mathrm{yr} \quad 100 \mathrm{yr} \quad 500 \mathrm{yr}$

6. Base-case alternative-fuel HD + LD ICEVs, $\mathrm{NO}_{\mathrm{x}}$ excluded,

NMOCs oxidize only ( $3.66 \mathrm{CO}_{2}$-equivaiency factor)

Methanol/NG

CNG

Ethanol/corn+coal

Hydride/nuclear electrolysis

LPG/oil and NG

Methanol/wood

CSNG/wood

Ethanol/wood

$\begin{array}{rrr}3.3 & 1.1 & 0.5 \\ 2.8 & -9.7 & -13.3 \\ 23.2 & 19.4 & 10.0 \\ -61.3 & -62.8 & -63.0 \\ -17.2 & -17.8 & -18.1 \\ -60.5 & -65.7 & -68.5 \\ -40.8 & -54.9 & -60.1 \\ -78.0 & -82.9 & -86.0\end{array}$

7. Base-case alternative-fuel LD ICEVs and EVs,

actual $\mathrm{CO}_{2}$ emissions only

Methanol/NG

$-5.2$

CNG

$-21.5$

Marginal U.S. mix/EV

$-10.4$

Ethanol/corn+coal

$-12.7$

Hydride/nuclear clectrolysis $\quad-62.7$

LPG/oil and NG

$-23.9$

Methanol/wood

$-74.7$

CSNG/wood

$-68.0$

Ethanol/wood

$-92.1$

8. Base-case alternative-fuel HD ICEVs, actual $\mathrm{CO}_{2}$ emissions only

Methanol/NG

16.1

CNG

. 1.0

Ethanol/corn+coal

8.7

Hydride/nuclear electrolysis

$-61.3$

LPG/oil and NG

$-1.5$

Methanol/wood

$-72.6$

CSNG/wood

$-63.1$

Ethanol/wood

$-95.0$ 
Percentage Change

in Emissions from

Baseline Value,

by Time Horizonb

Scenario Number and Description ${ }^{a}$

$20 \mathrm{yr} \quad 100 \mathrm{yr} \quad 500 \mathrm{yr}$

9. Lean-burn, low-emission, high-efficiency alternative-fuel

LD ICEVs and EVs

a. Methanol/NG: $30 \%$ efficiency advantage, $\mathrm{CO}$ reduced by $50 \%$

$-6.2-11.4 \quad-13.2$

from methanol base case; $\mathrm{NMOCs}$ and $\mathrm{CH}_{4}$ reduced by $25 \%$

from methanol base case.

b. CNG: $20 \%$ thermal efficiency advantage; $\mathrm{CO}$ reduced $75 \%$ from $\quad-13.6 \quad-21.6 \quad-24.6$

CNG base case; NMOCs reduced 25\% fron CNG base case;

$\mathrm{CH}_{4}$ reduced $33 \%$ from $\mathrm{CNG}$ base case.

c. Marginal U.S. mix/EV: Powertrain 6.1 times more efficient than ICEV powertrain.

d. Ethanol/corn+coal: $28 \%$ vehicle efficiency advantage over standard gasoline; $\mathrm{CO}$ reduced $50 \%$ from ethanol base case; NMOCs and $\mathrm{CH}_{4}$ reduced $25 \%$ from ethanol base case.

e. Hydride/nuclear electrolysis: $35 \%$ efficiency advantage over gasoline.

f. LPG/oil and NG: 20\% thermal efficiency advantage over gasoline; CO reduced $75 \%$ from LPG base case; NMOCs and $\mathrm{CH}_{4}$ reduced 25\% from LPG base case.

g. Methanol/wood: Vehicles same as in Scenario 9-a.

$\begin{array}{lll}-13.3 & -17.3 \quad-17.9\end{array}$

22.0 $\quad 7.8 \quad-3.6$

h. CSNG/wood: Vehicles same as in Scenario 9-b.

i. Ethanol/wood: Vehicles same as in Scenario 9-d.

$-53.8 \quad-62.7 \quad-65.3$

$\begin{array}{lll}-31.0 & -29.4 & -29.1\end{array}$

$\begin{array}{lll}-47.2 & -61.9 & -68.1\end{array}$

$\begin{array}{lll}-31.5 & -52.5 & -60.8\end{array}$

$-58.3 \quad-74.8 \quad-82.0$

10. High-ef ficiency alternative-fuel HD ICEVs

a. Methanol/NG: 5\% efficiency advantage over diesel HD ICEVs. $\quad 18.0 \quad 11.8 \quad 9.5$

b. CNG: $10 \%$ efficiency loss compared with diesel HD ICEVs. $\quad 9.8 \quad 1.5 \quad-1.8$

c. Ethanol/corn+coal: No efficiency loss compared with diesel $\quad 55.1 \quad 41.1 \quad 26.3$ HD ICEVs.

d. Hydride/nuclear electrolysis: $10 \%$ efficiency advantage over $\quad-34.6 \quad-51.4 \quad-58.2$ diesel HD ICEVs.

e. LPG/oil and NG: 10\% efficiency loss compared with diesel $\quad-6.3 \quad-6.7 \quad-6.8$ HD ICEVs.

f. Methanol/wood: 5\% efficiency advantage over diesel $\quad \begin{array}{lll}-29.8 & -54.4 & -64.7\end{array}$ HD ICEVs.

g. CSNG/wood: 10\% efficiency loss compared with diesel $\quad-12.5 \quad-41.8 \quad-54.1$ HD ICEVS.

h. Ethanol/wood: No efficiency loss compared with diesel $\quad-41.7 \quad-71.1 \quad-8.5$ HD ICEVs. 
Percentage Change

in Emissions from

Baseline Value,

by Time Horizon ${ }^{b}$

Scenario Number and Descriptiona

$20 \mathrm{yr} \quad 100 \mathrm{yr} \quad 500 \mathrm{yr}$

11. Dual-fuel alternative-fuel LD ICEVs

a. Methanol/NG: Operation on M85; 5\% efficiency advantage on

8.0

3.4

2.0

methanol over dedicated gasoline vehicles (Sperling and

Deluchi, 1991; Sapre, 1988); $15 \%$ lower $\mathrm{NO}_{x}$ emissions than

dedicated gasoline or methanol vehicle (Sperling and DeLuchi, 1991; Sapre, 1988); $0.029 \mathrm{~g} / \mathrm{mi} \mathrm{CH}_{4}$ (App. M); evaporative emissions (in $\mathrm{g} / \mathrm{gal}$ ) $50 \%$ of those from gasoline (assuming that the Reid vapor pressure [RVP] of M85 is $70 \%$ that of gasoline

[Sapre, 1988], that the vapors have $70 \%$ of the weight of gasoline vapors, and that the evaporative emission control system is the same as for gasoline); tailpipe NMOC emissions $21 \%$ higher than from dedicated M1O0) vehicles (EPA, Analysis of the Economic and Environmental Effects of Methanol as an Automotivi: Fuei, 1989); NMOC emissions contain $55 \%$ carbon.

b. Methanol/NG: Same as Scenario 11-a, except $50 \%$ of vehicle miles traveled (VMT) on M85, $50 \%$ on gasoline; $3.5 \%$ thermal efficiency advantage over dedicated gasoline vehicle; $9 \%$ reduction in $\mathrm{NO}_{x}$ emissions compared with dedicated gasoline or methanol vehicle; tailpipe NMOC emissions $10 \%$ higher than those from dedicated M100 vehicle (emissions assumptions [based on data in Sapre, 1988] indicate that an increase in efficiency, a decrease in $\mathrm{NO}_{x}$, and an increase in NMOCs are proportional to methanol content); same g/gal evaporative emissions as gasoline (the RVP of M50) is $12 \%$ higher than the RVP of M0 according to Sapre, 1988; 1 assume that the molecular weight of M50 evaporative emissions is slightly less than that of gasoline evaporative emissions); $65 \%$ carbon in NMOC.

d. CNG: Operation on CNG; no thermal efficiency advantage over dedicated gasoline vehicle; 150-mi range on CNC (smaller tank than in dedicated vehicle) but retains the gasoline tank; $\mathrm{CH}_{4}$ and NMOC emissions $10 \%$ higher than from deaicated CNG vehicle.

c. Ethanol/corn+coal: E85; $4 \%$ efficiency advantage over dedicated gasoline vehicle; $\mathrm{NO}_{x}$ and $\mathrm{CH}_{4}$ emissions same as from methanol flexible-fuel vehicle (FFV) (EI-A, Analysis of the Economic and Environmental Effects of Ethanol as an Automotive Fuel, 1990); NMOC tailpipe emissions $21 \%$ higher than from dedicated E100) vehicle; g/gal evaporative emissions $30 \%$ of those from gasoline; NMOC emissions contain $66 \%$ carbon.

i. LPG/oil and NG: No therm 1 efficiency advantage over dedicated gasoline; operation on LPC $100 \%$ of the time; 250 -mi driving range on LPG; retain gasoline tank; $\mathrm{CH}_{4}$ and NMOC emissions $10 \%$ higher than from dedicated L.PC vehicle.

g. Ethanol/wood: Same changes in assumptions about vehicles as in Scenario 11-e. $-18.4-17.5-17.3$

$\begin{array}{lll}3.6 & -8.5 & -12.8\end{array}$

$\begin{array}{lll}36.3 & 22.8 & 12 .()\end{array}$

$\begin{array}{lll}4.0 & 1.7 & 1.0\end{array}$

$(2.8000$

$-42.6 \quad-58.3 \quad-65.0$ 
TABLE 12 (Cont'd)

\author{
Percentage Change \\ in Emissions from \\ Bascline Value, \\ by Time Horizon' \\ $20 \mathrm{yr} \quad 100 \mathrm{yr} \quad 500 \mathrm{yr}$
}

Scenario Number and Description ${ }^{n}$

\title{
12. Gasoline LD ICEVs
}

a. Refinery energy requirement higher than in base case (0.20 Btu/Btu of gasoline).

b. Crude recovery energy $25 \%$ higher (due to low-quality crude).

c. Venting and flaring emissions $25 \%$ higher; $10 \%$ vented (versus $6 \%$ in base case).

d. Tailpipe emissions same as for standard gasoline $(0.40 \mathrm{~g} / \mathrm{mi}$ for NMOCs, $7.21 \mathrm{~g} / \mathrm{mi}$ for $\mathrm{CO}$ ).

e. Methyl tertiary butyl ether (MTBE) does not displace crude; extra crude is input as refinery fuel.

f. Scenarios 12-a through 12-e combined.

g. 1987 level of crude imports (less international crude movement than there is in year-2000 scenario).

13. Diesel LD ICEVs (versus base-case gasoline LD ICEVs)

a. $39 \mathrm{mpg}$ (indirect-injection diesel engine; $27 \%$ efficiency advantage over standard gasoline); low-sulfur diesel; $400-\mathrm{mi}$ range; $1.10 \mathrm{~g} / \mathrm{mi}$ for $\mathrm{NO}_{x}, 1.45 \mathrm{~g} / \mathrm{mi}$ for $\mathrm{CO}, 0.40 \mathrm{~g} / \mathrm{mi}$ for NMOCs, $0.02 \mathrm{~g} / \mathrm{mi}$ for $\mathrm{CH}_{4}, 0.054 \mathrm{~g} / \mathrm{mi}$ for $\mathrm{N}_{2} \mathrm{O}$ (see App. B); 150,000-mi life; $100 \mathrm{lb}$ more weight than gasoline LDV.

b. $36 \mathrm{mpg}$; all else same as in Scenario 12-a.

c. $42 \mathrm{mpg}$ ( $45 \%$ efficiency advantage; direct-injection engine).

d. $45 \mathrm{mpg}$.

e. Regular diesel (not low-sulfur diesel); all else same as in

Scenario 12-a.

$\begin{array}{rrr}1.1 & 1.2 & 1.2 \\ 0.7 & 0.6 & 0.6 \\ 0.9 & 0.5 & 0.3 \\ 1.2 & 0.4 & 0.2 \\ & & \\ 0.2 & 0.2 & 0.2 \\ & & \\ 4.1 & 2.9 & 2.5 \\ & -0.5 & \\ & & \end{array}$

$-6.0 \quad-13.7-16.2$

14. Gasoline HD ICEVs (versus base-case diesel HD ICEVs)

a. $4.8 \mathrm{mpg}$ on reformulated gasoline (versus 6.0 on diesel; $25 \%$ advantag? for diesel); $1.13 \mathrm{~g} / \mathrm{mi}$ for exhaust NMOCs $(15 \%$ reduction from MOBILE4 value of Table B. 3 to account for effect of unreformulated gasoline); $1.27 \mathrm{~g} / \mathrm{mi}$ evaporative and refueling losses; $0.18 \mathrm{~g} / \mathrm{mi}$ for $\mathrm{CH}_{4} ; 14.05 \mathrm{~g} / \mathrm{mi}$ for $\mathrm{CO}(15 \%$ reduction from MOBILE4 value of Table B.3 to account for effect of reformulated gasoline); $4.26 \mathrm{~g} / \mathrm{mi}$ for $\mathrm{NO}_{\mathrm{x}}$ (emission factors from Table B.3); $0.06 \mathrm{~g} / \mathrm{mi}$ for $\mathrm{N}_{2} \mathrm{O}$ (Table N.1); $500 \mathrm{lb}$ less weight (versus diesel HDV); lifetime $33 \%$ that of diesel HD ICEV (based on data in California Air Resources Board, November 1986).

b. Same as in Scenario $14-\mathrm{a}$, but $4.5 \mathrm{mpg}$ (33\% advantage for diesel).

c. Same as in Scenario 14-a, but $\mathrm{NO}_{\mathrm{x}}$ emissions excluded.

$\begin{array}{lll}15.0 & 29.1 & 34.2 \\ 32.8 & 31.4 & 30.8\end{array}$


Percentage Change in Emissions from

Baseline Value, by Time Horizon ${ }^{b}$

15. Alternative-fuel LD ICEVs in European Economic Community (EEC) (versus gasoline LD ICEVs in EEC) d $^{\text {a }}$

a. Methanol/NG: Stoichiometric operation.

b. Methanol/NG: Lean burn (25\% efficiency advantage; lower $\mathrm{CO}, \mathrm{NMOC}$, and $\mathrm{CH}_{4}$ emissions).

c. CNG: Stoichiometric operation.

d. CNG: Lean burn (20\% efficiency advantage; lower $\mathrm{CO}$, $\mathrm{NMOC}$, and $\mathrm{CH}_{4}$ emissions).

c. Ethanol/corntcoal: Stoichiometric operation.

f. Ethanol/corn+coal: Lean burn (24\% efficiency advantage; lower $\mathrm{CO}, \mathrm{NMOC}$, and $\mathrm{CH}_{4}$ emissions).

g. Hydride/nuclear electrolysis: Stoichiometric operation.

h. Hydride/nuclear electrolysis: Lean burn (30\% efficiency advantage).

i. LPG/oil and NG: Stoichiometric operation.

j. LPG/oil and NG: Lean burn (20\% efficiency advantage; lower $\mathrm{CO}, \mathrm{NMOC}$, and $\mathrm{CH}_{4}$ emissions).

k. Methanol/wood: Stoichiometric operation.

1. Methanol/wood: Lean burn (25\% efficiency advantage; lower $\mathrm{CO}, \mathrm{NMOC}$, and $\mathrm{CH}_{4}$ emissions).

$\mathrm{m}$. CSNG/wood: Stoichiometric operation.

n. CSNC/wood: Lean burn (20\% efficiency advantage; lower CO, $\mathrm{NMOC}$, and $\mathrm{CH}_{4}$ emissions).

(). Ethanol/wood: Stoichiometric operation.

p. Ethanol/wood: Lean burn $24 \%$ efficiency advantage; lower $\mathrm{CO}, \mathrm{NMOC}$, and $\mathrm{CH}_{4}$ emissions).

$\begin{array}{rrr}1.1 & -1.1 & -1.9 \\ -8.8 & -9.2 & -9.1 \\ & & \\ -7.0 & -14.8 & -18.5 \\ -17.8 & -22.8 & -25.3 \\ & & \\ 23.6 & 16.8 & 6.7 \\ 11.8 & 7.3 & -1.3 \\ & & \\ -58.8 & -69.3 & -73.5 \\ -59.6 & -70.3 & -74.5 \\ & & \\ -22.6 & -21.9 & -21.7 \\ -31.0 & -28.7 & -27.8 \\ & & \\ -33.5 & -53.7 & -63.9 \\ -40.7 & -57.7 & -66.2 \\ & & \\ -21.8 & -46.4 & -58.6 \\ -41.4 & -51.7 & -61.7 \\ & & \\ -39.4 & -63.1 & -75.0 \\ -46.2 & -66.3 & -76.5\end{array}$

16. Allernative-fuel HD ICEVs in EEC (versus diesel HD ICEVs in EEC) ${ }^{d}$ Methanol/NG

CNG

Ethanol/corn+coal

Hydride/nuclear electrolysis

1.PC

Methanol/wood

CSNG/wood

Ethanol/wood

$\begin{array}{rrr}-18.6 & -2.1 & 7.8 \\ -8.8 & -5.4 & -3.6 \\ 4.6 & 20.6 & 21.1 \\ -66.0 & -71.1 & -74.4 \\ -16.5 & -9.5 & -5.2 \\ -47.8 & -58.3 & -65.6 \\ -22.3 & -41.8 & -54.7 \\ -49.8 & -66.6 & -78.0\end{array}$


Percentage Change

in Emissions from

Baseline Value, by Time Horizon b

Scenario Number and Descriptiona

$20 \mathrm{yr} \quad 100 \mathrm{yr} \quad 500 \mathrm{yr}$

17. EVs versus gasoline LD ICEVs used for city only driving in EEC, Japan, or Canadad
a. Canada
b. France
c. Germany
d. Japan
e. Sweden
f. United Kingdom
g. European Community

$\begin{array}{lll}-66.7 & -68.4 & -68.7 \\ -83.8 & -81.5 & -80.4 \\ -51.9 & -44.9 & -41.3 \\ -54.5 & -56.0 & -55.7 \\ -84.0 & -81.6 & -80.5 \\ -35.2 & -25.4 & -20.4 \\ -53.4 & -46.3 & -42.7\end{array}$

19. Methanol/NG LD ICEVs
a. Methanol from advanced conversion plants ( $71 \%$ efficient).
b. All methanol from remote NG (versus $75 \%$ in base case).
c. All methanol from domestic gas (no international transport); advanced conversion plants ( $71 \%$ efficient).
d. $\mathrm{NO}_{x}$ emissions from methanol-from-NG plants $75 \%$ lower than in base case of Table A.1.
c. Methanoi made from flared gas $\left(\mathrm{CO}_{2}\right.$ from methanol plant set equal to zero; $\mathrm{CH}_{4}$ leaks given a $\mathrm{CO}_{2}$ credit; biomethanol vehicle emission factors used; compared with original base-case gasoline emission factor, $491.2 \mathrm{~g} / \mathrm{mi}$ ).

$-6.9$

$-0.0$

$-10.4$

f. Same g/gal evaporative emissions as from gasoline vehicle (control system is reduced to save cost).

g. Natural gas liquids (NGL) not removed from NG (zero energy requirements at NGL plant; $2 \%$ boost in methanol production; gas has less $\mathrm{CH}_{4}, \mathrm{C}_{2}$, and higher hydrocarbon emissions.

h. $10 \%$ thermal efficiency advantage over gasoline.

i. Best for methanol/NG: Scenarios 18-c, d, and g combined with 9-a.

j. Worst for methanol/NG: Scenarios 18-b and h, plus 25\% higher tailpipe NMOC emissions than in methanol base case.

k. $75 \%$ of methanol from base-case NCi; $25 \%$ from base-case coal.

19. Methanol/NG HD ICEVs
a. Same as Scenario 18-c only for HD ICEVs.
b. Low-NO conversion plants $(75 \%$ lower emissions than in base case of Table A.1).
c. Methanol/NG 5\% more thermally efficient than diesel HD ICEVs.
d. Methanol/NG $10 \%$ less thermally efficient than diesel HD ICEVs.
c. Best for methanol/NG: Scenarios 19-a, b, and c combined with 18-g; $\mathrm{CO}, \mathrm{CH}_{4}$, and NMOCs $25 \%$ lower than in methanol/NG HD ICEV base case.
f. Worst for methanol/NG: Scenarios 18-b and 19-d; $\mathrm{CO}, \mathrm{CH}_{4}$, and NMOCs $25 \%$ higher than in methanol/NG HD ICEV base case.
g. $75 \%$ of methanol from base-case NG; $25 \%$ from base-case coal. 
Percentage Change

in Emissions from

Baseline Valuc, by Time Horizon ${ }^{b}$

Scenario Number and Descriptiona

$20 \mathrm{yr} \quad 100 \mathrm{yr} \quad 500 \mathrm{yr}$

20. Methanol/coal LD ICEVs (base case is second-generation coal conversion, $56 \%$ efficient)

a. OTM/LPM/IGCC (once-through methanol/liquid-phase

30.6

methanol synthesis/integrated gasification combined-cycle)

technology coal conversion; $70 \%$ efficient; very low $\mathrm{NO}_{x}$

emissions.

b. $\mathrm{CH}_{4}$ emissions from coal mining reduced to $250 \mathrm{ft}^{3} /$ ton (versus

57.0

380 in the base case).

c. Lean-burn methanol vehicles (Scenario 9-a); base-case coal conversion.

d. Best for methanol/coal: Scenarios 20-a, b, and $c$.

e. $\mathrm{CO}_{2}$ removed from coal-to-methanol plants.

f. Scenarios 20-a and e.

$11.8 \quad 15.1$

$-14.4$

$-19.5$

21. Methanol/coal HD ICEVs

a. OTM/LPM/IGCC.

b. Best for methanol/coal: Scenarios 21-a, 20-b, and 19-c, plus $25 \%$ lower $\mathrm{CO}, \mathrm{NMOCs}$, and $\mathrm{CH}_{4}$ than in methanol/coal HD ICEV base case.

c. $\mathrm{CO}_{2}$ removed from coal-to-methanol plants.

d. Scenarios 21-a and c.

22. Methanol/wood LD ICEVS

a. Non- $\mathrm{CO}_{2}$ emissions from wood-to-methanol plants reduced by $75 \%$ from base case (Table A.1).

b. Methanol/wood used by all trucks and tractors involved in the fuel cycle.

c. No SRIC (short-rotation intensive-cultivation) acreage fertilized (carbon factor of $50 \%$ in base case).

d. 9 tons/acre yield (versus 6 in base case).

c. Takes into account sequestering of $\mathrm{CO}_{2}$ resulting from converting grassland to forest.

f. Add 0.10 Btu of energy embodied in materials (in the

$-4.3$ conversion plant and in field eqiupment) per Btu of ethanol; assume all material energy from oil.

g. All acreage fertilized; lime added on all acres $(2000) \mathrm{lb} /$ acre)

h. $\mathrm{N}_{2} \mathrm{O}$ emissions per lb of fertilizer tripled over base case.

$-46.3$

$-56.2$

i. Best for methanol/wood: Scenarios 9-a and 22-a, b, c, and d.

j. Worst for methanol/wood: Scenarios $18-\mathrm{h}$ and 22-f, $g$, and $h$. 


\section{Percentage Change \\ in Emissions from \\ Baseline Value, \\ by Time Horizon'}

Scenario Number and Description ${ }^{\mathrm{a}}$
20) yr 100) yr 500$) \mathrm{yr}$

23. NG LD ICEVs

a. $\mathrm{CH}_{4}$ tailpipe emissions of $0.8 \mathrm{~g} / \mathrm{ml}$ (versus 1.2 in base case).

$-15.3$

b. Gas turbine instead of electricity used to compress gas (assume

$-12.8$ $25 \%$ efficient turbine).

c. CNG tanks last for $300,000 \mathrm{mi}$ in LD ICEVs; vehicles themselves $-16.5$ last $130,000 \mathrm{mi}$.

d. CNG compressor located on high-pressure pipeline; energy requirement reduced to 0.02 Btu of electricity/Btu of CNG.

c. All gas-fired power used to drive compressor.

$-14.9$

g. 150-mi range (versus 250 in base casc).

$-15.1$

$-15.0$

h. All NG from dry gas (no NGL plant needed).

i. Dedicated $\mathrm{CNG}$ vehicles only $5 \%$ more thermally efficient than

$-10.7$ gasoline vehicles.

j. CNG from foreign $\mathrm{LNG}$ from flared gas $\left(\mathrm{CO}_{2}\right.$ emissions from gas not counted as a net emission; see description in Scenario 23-r; result is compared with gasoline at $491.2 \mathrm{~g} / \mathrm{mi}$ ).

$k$. LNG from forcign LNG from flared gas $\left(\mathrm{CO}_{2} \mathrm{cmissions}\right.$ from gas not counted as a net emission; sec Scenario 23-r; result is compared with gasoline at at $491.2 \mathrm{~g} / \mathrm{mi}$ ).

1. $\mathrm{CH}_{4}$ tailpipe emissions of $2.1 \mathrm{~g} / \mathrm{mi}$.

$\mathrm{m}$. Same CO emissions as gasoline vehicle on standard gasoline (versus 50 \% reduction in base case).

n. Hard to meet the $\mathrm{NO}_{\mathrm{x}}$ standard: Cannot increase compression ratio (no thermal efficiency advantage over gasoline); larger tanks to compensate for lower fuel efficiency; no CO reduction (same CO emissions as gasoline vehicle on standard gasoline); $25 \%$ higher NMOCs and $\mathrm{CH}_{4}$ than in $\mathrm{CNG}$ base case because of need to operate slightly rich to meet $\mathrm{NO}_{\mathrm{x}}$ standard.

o. All coal-fired power used to drive compressor.

p. CNG from unconventional sources of NGi $(25 \%$ extra recovery energy).

q. 350-mi range (larger, heavier tanks reduce fucl economy).

r. CNG from remote LNG (0.10) Btu of NG for liquefaction/Btu of

LNG; 0.059 Btu for transpert/Btu of LNG delivered $164 \%$ NG, $36 \%$ fucl oill); (0.)25 Btu for regasification/Btu of CNG; extra pipeline transport; result is compared with gasoline at $491.2 \mathrm{~g} / \mathrm{mi}$.

s. All NG from wet gas (must go through NGL plant).

t. LNG from remote $L N G$ (no regasification; LNG used around port city; shorter pipeline transport than in NG vehicle base case; see Scenario 23-r; result is compared with gasoline at $491.2 \mathrm{~g} / \mathrm{mi}$ ). 


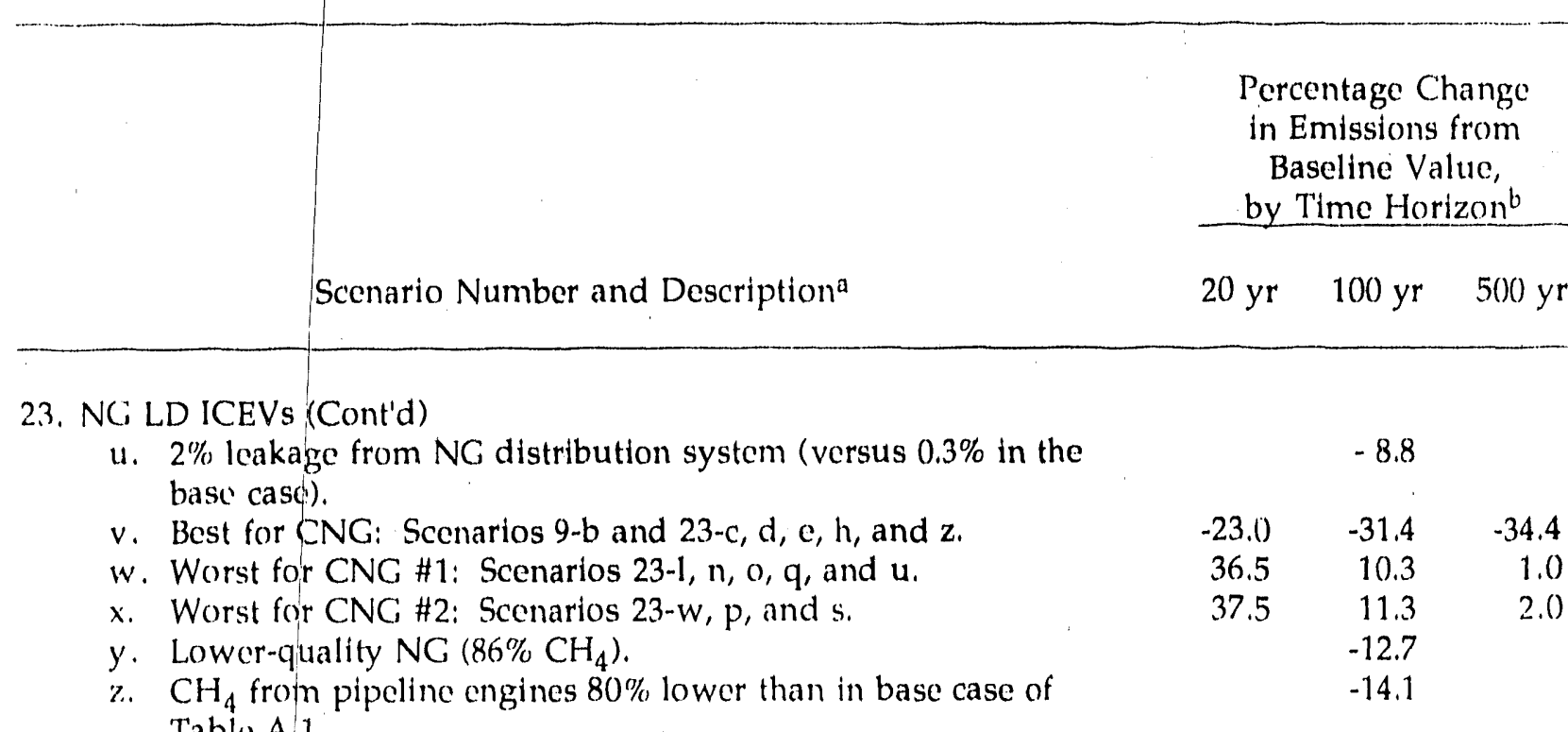

24. CNG HD ICEVS

a. $10 \%$ thermal efficiency loss compared with diesel HDVs.

b. $20 \%$ thermal efficiency loss compared with diesel HDVs. 11.6

c. $2 \%$ distribution system leaks. 13.2

d. $\mathrm{CH}_{4}$ tailpipe emissions of $1 \mathrm{~g} / \mathrm{mi}$. 4.9

c. $\mathrm{CH}_{4}$ tailpipe emissions of $5 \mathrm{~g} / \mathrm{mi}$. $\quad 7.6$

f. 25\% lower CO and NMOC emissions than in CNG base case. 6.1

g. 5()\% higher $\mathrm{CO}$ and NMOC emissions than in CNG base case. 6.5

h. Best for CNG: Scenarios 23-d, c, and $z$ combined with 24-a, d, $-2.0 \quad-8.6$ and $f$.

i. Worst for CNG: Scenarios 23-o and p and 24-b, c, e, and g. $\quad 44.0 \quad 27.6 \quad 20.7$

25. L.PG LD ICEVS

a. All LPG from petroleum refineries (versus $39 \%$ in base case).

$-19.8$

b. All LPG from NGL plants (versus $61 \%$ in base case).

$-25.2$

c. LPG is $100 \%$ fropane (versus $95 \%$ propane $/ 5 \%$ butane in base case).

d. $L P C$ is $50 \%$ propane, $50 \%$ butane.

$-22.7$

c. Same CO emissions as gasoline vehicle on standard gasoline.

$-22.6$

f. LPC only $5 \%$ more thermally efficient than gasoline.

$-20.4$

g. Best for LPG: Scenarios 25-b and $c$ and 9-f.

$-31.4$

h. Worst for LPG \#1: Scenarios 25-a, e, and f.

i. Worst for LPG \#2: Scenario 25-h, plus ().18 Btu of refinery energy/Btu of L.PG (see App. H). 
Percentage Change

in Emissions from

Baseline Value,

by Time Horizon

Scenario Number and Descriptiona

$20 \mathrm{yr} \quad 100 \mathrm{yr} \quad 500 \mathrm{yr}$

26. LPG HD ICEVs

a. All LPG from refineries. $\quad 2.1$

b. All LPG from NGL plants.

c. LPG is $100 \%$ propane. $\quad-2.5$

d. LPG is $50 \%$ propane, $50 \%$ butane. $\quad-1.9$

c. LPG has $10 \%$ lower thermal efficiency than diesel HDVs. $\quad-6.7$

f. LPG has $20 \%$ lower thermal efficiency than diesel HDVs. 2.4

g. $\mathrm{CO}, \mathrm{CH}_{4}$, and NMOCs are $25 \%$ lower than in LPG base case. $\quad-2.7$

h. $\mathrm{CO}, \mathrm{CH}_{4}$, and NMOCs are $50 \%$ higher than in LPG base case. -1.9

i. Best for LPG: Scenarios 26-b, c, c, and g. $\quad-9.7 \quad-9.8$

j. Worst for LPG \#1: Scenarios 26-a, $f$, and $h$. $\quad 6.6 \quad 7.8$

k. Worst for LPG \#2: Scenario 26-j, plus ().18 Btu of refinery 18.7

$-9.7$ energy/Btu of LPG (see App. H).

27. Ethanol/corn LD ICEVs

a. Lower $\mathrm{N}_{2} \mathrm{O}$ emissions: $0.8 \% \mathrm{~N}$ evolved as $\mathrm{N}_{2} \mathrm{O}$ on site instead of $1.3 \%$; $25 \%$ additional $\mathrm{N}_{2} \mathrm{O}$ off site instead of $100 \%$; corn is assigned $50 \%$ of the emissions instead of $80 \%$.

b. Low-input agriculture: Reduce fertilizer inputs by $70 \%$.

c. Fertilizer manufacture $30 \%$ more efficient than in ethanol base case.

d. Ethanol made from corn diverted from fecd; diverted corn feed made up of grass, not crops (no emissions from fertilized agriculture assignable to ethanel).

c. Ethanol vehicles only $9 \%$ more efficient than gasoline vehicles.

f. By-product credits estimated as a function of value or energy content; $45 \%$ of emissions assigned to by-products.

g. Advanced coal-to-ethanol conversion technology; $0.45 \mathrm{Btu}$ of heat/Btu of ethanol; 0.05 Btu of electricity/Btu of ethanol.

h. Corn-to-ethanol plants use U.S. average power mix.

i. NG instead of coal used as process fucl; no sulfur-to-fertilizer credit.

j. Corn stover instead of coal used as process fuel (no sulfur-tofertilizer credit; need extra fertilizer to make up for nutrients lost due to removing residue).

k. Do not dry distillers' dried grains and solubles (DDGS); subtract 0.30 Btu of heat/Btu of ethanol.

1. Reduce by-product credits by $15 \%$.

m. Add amortized emissions from building conversion plant (0.05 Btu of embodied energy in physical plant/Btu of ethanol) and from building farm equipment (().10 Btu of embodied energy in equipment/Btu of ethanol); assume all this Btu energy is from oil. 
Percentage Change

in Emissions from

Baseline Value,

by Time Horizon ${ }^{b}$

Scenario Number and Description ${ }^{a}$

$20 \mathrm{yr} \quad 100 \mathrm{yr} \quad 500 \mathrm{yr}$

27. Ethano!/corn LD ICEVs (Cont'd)

$n$. Land use effocts. One-time emissions from clearing a forest to plant corn (see App. K).

0 . Land use effects: Grassland cleared to plant crops (one-time release of 20 metric tons of $\mathrm{CO}_{2} /$ acre, mainly from soil; sce Table K.12).

p. Marginal farm land used: Farming energy (but not fertilizer) requirements increased by $50 \%$.

q. Corn-to-ethanol plant uses all coal-fired electricity.

Equivalent to an additional 50-60 yr of fuel-cycle emissions Equivalent to an additional 5-6 yr of fuei-cycle emissions 25.)

23.0

24.2 cycle (this scenario actually is favorable, if cthanol is better than diesel fuel).

s. Best for ethanol/corn+coal: Scenarios $27-a, b, c, f, g, h$, and $r$, and 9-d.

t. Best for cthanol/corn+corn stover: Scenarios 27-a, b, c, f, h, j, and $r$, and $9-d$.

u. Maximum best for ethanol/corn+coal: Scenarios 27-s and k.

v. Maximum best for ethanol/corn+corn stover: Scenarios 27-t and $\mathrm{k}$.

w. Worst for ethanol/corn+coal: Scenarios 27-c, 1, m, o, p, and q.

$\begin{array}{lll}-31.8 & -44.5 & -50.0 \\ -47.8 & -61.1 & -67.1 \\ & & \\ -45.9 & -58.0 & -63.6 \\ -49.9 & -62.2 & -67.8 \\ 78.4 & 50.3 & 33.8\end{array}$

28. Ethanol/wood LD ICEVs

a. Non- $\mathrm{CO}_{2}$ emissions from wood-to-ethanol plants $75 \%$ less than in base case of Table A.1.

b. Biocthanol used by all trucks and tractors involved in the fuel cycle.

c. No short-rotation intensive cultivation (SRIC) acreage fertilized (versus $50 \%$ in base case).

d. 9 short tons/acre yield (versus 6 in base case).

c. Land-use effects: One-time sequestering of $\mathrm{CO}_{2}$ resulting from converting grassland to forest (sce App. K).

f. 0.10 Btu of energy embodied in materials (in the physical plant and in field equipment) added per Btu of ethanol; assume that all this energy is oil.

g. All acreage fertilized.

$-74.7$

$-78.4$

$-77.1$

$-74.4$

Canceis about $40 \mathrm{yr}$ of fucl-cycle emissions

$-63.2$

i. Lime added on all fertilized acres (2000) lb/acre).

i. $\mathrm{N}_{2} \mathrm{O}$ emissions per $\mathrm{lb}$ of fertilizer tripled over those in base case.

j. No electricity generation credit.

$-7(0.4$

k. Ethanol vehicles only 9\% more efficient than gasoline vehicles.

1. Best for ethanol/wood: Scenarios 9-d and 28-a, b, c, and d.

$m$. Worst for ethanol/wood: Scenarios $28-f, g, h, i, j$, and $k$. 
TABLE 12 (Cont'd)

\begin{tabular}{|c|c|}
\hline & $\begin{array}{l}\text { Percentage Change } \\
\text { in Emissions from } \\
\text { Baseline Value, } \\
\text { by Time Horizon' }\end{array}$ \\
\hline Scenario Number and Description ${ }^{a}$ & $100 \mathrm{yr}$ \\
\hline
\end{tabular}

29. EVs (versus gasoline LD ICEVs)

a. Very advanced EVs: 6.5 times more efficient than ICEVs (this factor accounts 'or the use of drag-reducing techniques); ultralightweight materials; $95 \%$ battery-recharging efficiency; 140 Watt-hour $/ \mathrm{kg}, 80 \%$-efficient battery (battery weighs $496 \mathrm{lb}$; whole vehicle, including the battery, weigh same as comparable ICEV).

b. EVs have a 200,000-mi life.

c. EVs in mixed city/highway driving: Same EV and ICEV as in the city-driving-only base case, but the ICEV gets $30 \mathrm{mpg}$ in city/highway driving, and the EV powertrain is only 4.7 times more efficient than ICEV powertrain (versus 5.7 times more efficient in the city-driving-only case).

d. EVs with lead/acid battery: 40 Watt-hour $/ \mathrm{kg} ; 65-\mathrm{mi}$ range; $75 \%$ recharging efficiency (battery weighs $1,224 \mathrm{lb}$; whole vehicle weighs $981 \mathrm{lb}$ more than comparable gasoline vehicle).

c. Battery only $60 \%$ efficient due to repeated shallow discharging (versus $75 \%$ in base case).

f. Best for EVs using marginal U.S. power mix: Scenarios 29-a and $b$.

g. Worst for EVs using marginal U.S. power mix: Scenarios 29-c, $\mathrm{d}$, and e; 1,470)-lb Pb/acid battery; 1,242 lb extra vehicle weight; more weight than in Scenario $29-\mathrm{d}$ because the vehicle is less efficient and the range is the same.

h. EVs using New York average pow'er mix (16.9\% coal, $39.3 \%$ nuclear, $14.5 \%$ NG, $26 \%$ oil).

i. EVs using Chicago average power mix (21.3\% coal, $77.7 \%$ nuclear, $0.4 \%$ NG, $0.6 \%$ oil).

j. EVs using Houston average power mix $(31.4 \%$ coal, $11.7 \%$ nuclear, $56.4 \%$ NG, $0.5 \%$ oil).

k. EVs using Los Angeles average power mix (31.2\% coal, $24.5 \%$ nuclear, $33.1 \%$ gas, $5.3 \%$ oil).

1. EVs using Atlanta average power mix (79.3\% coal, $19.2 \%$ nuclear, $0 \%$ NG, $0.3 \%$ oil).

$m$. EVs recharged by base-case nuclear power only.

$n$. EVs recharged by nuclear power characterized by 1982 mining energy intensity; 1977-2010 energy intensity for uranium enrichment and burn-up rate ("new-plants" scenario; see App. I).

o. EVs recharged by nuclear power only; advanced uraniumenrichment lechnologies: U-AVLIS and/or gas centrifuge (both are 20 times more efficient than gascous diffusion).

p. EVs recharged by conventional cod-fired plants only. 


\section{Percentage Change in Emissions from \\ Baseline Value, by Time Horizon ${ }^{b}$}

\section{Scenario Number and Description ${ }^{a}$}

$20 \mathrm{yr} \quad 100 \mathrm{yr} \quad 500 \mathrm{yr}$

29. EVs (versus gasoline LD ICEVs) (Cont'd)

q. EVs recharged by coal-gasification/fuel-cell power plants (see

Table D.6 for power-plant efficiency and emissions).

r. Best for EVs recharged by coal-fired plants only: Scenarios 29-a, $b$, and $\mathrm{q}$, plus $250 \mathrm{ft}^{3} \mathrm{CH}_{4} /$ ton of coal from coal mining.

s. Worst for EVs recharged by coal-fired plants only: Scenarios 29-c, d, e, and $p$.

t. EVs recharged by conventional oil-fired plants only.

u. EVs recharged by conventional gas-fired plants only $(75 \%$ boilers; 25\% turbines).

v. EVs recharged by natural-gas/fuel-cell puwer plants (see Table D.6 for power-plant efficiency and emissions).

w. Best for FVs recharged by gas-fired plants only: Scenarios 29-a, $\mathrm{b}$, and $\mathrm{v}$.

$x$. Scenario 29-r, plus $\mathrm{CO}_{2}$ remioved from coal-fired plants.

$y$. EVs have an 80 -mi range (versus 130 in base case); $398-\mathrm{lb}$ battery; 106-lb total extra vehicle weight.

z. EVs have a 180 -mi range; $1171-\mathrm{lb}$ battery; $925 \mathrm{lb}$ extra vehicle weight.

aa. High-end estimate of $\mathrm{N}_{2} \mathrm{O}$ from corona discharge from power lines $(0.21 \mathrm{~g} / \mathrm{kWh})$.

ab. EVs recharged by biomass-gasification/fuel-cell power plants (see Table D.6 for power-plant efficiency and emissions).

30. Hydrogen LD ICEVS

a. Hydride ICEVs: Hydride lasts for $600,000 \mathrm{mi}$.

b. Hydride ICEVs: 300)-mi driving range (versus 150)-mi range in -51.5 base case).

c. Hydride ICEVs: U-AVLIS or gaseous-centrifuge uranium enrichment (20 times more efficient than gaseous diffusion).

d. Hydride ICEVs: Solar electrolysis, U.S. average power mix for compression.

c. $\mathrm{LH}_{2}$ ICEVs: All liquefaction power comes from coal-fired 9.6 plants (at service station).

f. $\mathrm{LH}_{2}$ ICEVs: All liquefaction power comes from nuclear plants. $\quad-65.6$

g. $\mathrm{LH}_{2}$ ICEVs: Gas centrifuge or U-AVLIS enrichment.

h. LH $\mathrm{LH}_{2}$ ICEVs: Scenarios 30-f and g combined.

i. $\mathrm{LH}_{2}$ ICEVs: Solar electrolytic hydrogen; liquefiers use solar $\quad-82.9$ power.

j. $\quad \mathrm{LH}_{2}$ ICEVs: Solar electrolytic hydrogen; U.S. average power $\quad-28.7$ mix for liquefaction. 
TABLE 12 (Cont'd)

\section{Percentage Change \\ in Emissions from \\ Baseline Value, \\ by Time Horizon?}

Scenario Number and Description ${ }^{\mathrm{a}}$

$20 \mathrm{yr} \quad 100 \mathrm{yr} \quad 50() \mathrm{yr}$

31. LD fuel-cell vehicles

a. Best for methanol/NG/fuel cell: Same as Scenarios 18-c and d. -46.)

b. Best for methanol/coal/fuel cell: Same as Scenarios 20-a and b. -19.7

c. Best for methanol/wood/fuel cell: Same as Scenarios 22-a, b, c, and d.

d. Scenario 31-b plus $\mathrm{CO}_{2}$ disposal. $\quad-51.8$

aThe original petroleum-fuel base case makes estimates of total fuel-cycle, $\mathrm{CO}_{2}$-equivalent emissions in the United States in the year 2000. It assumes that light-duty vehicles (LDVs) run on reformulated gasoline and that heavy-duty vehicles (HDVs) run on reformulated diesel fuel. The assumed vehicle efficiencies or fuel economy, in miles per gallon ( $\mathrm{mpg}$ ), are as shown below in this footnote. The original input values for the different variables associated with the base case are specified in Tables 2 through 7, A.1, and B.2 (for emissions fron. vehicles), C.1 and C.3 (for fuel specificatio.ss), D.4 (for emissions from power plants), E.1 (for feedstock and fuel transport), and so on. For the alternativefuel scenarios considered here, the description lists all the base-case variables whose values have changed to make the scenario. All variables not specifically mentioned retain their base-casc values.

The original base-case emissions from vehicles running on reformulated gasoline and lowsulfur diesel fuel are as follows:

\begin{tabular}{|c|c|c|c|c|c|c|}
\hline \multirow[b]{2}{*}{ Fuel } & \multirow[b]{2}{*}{$\begin{array}{c}\text { Vehicle } \\
\text { Type }\end{array}$} & \multirow{2}{*}{$\begin{array}{l}\text { Efficiency or } \\
\text { Fuel Economy } \\
\text { (mpg) }\end{array}$} & \multirow[b]{2}{*}{$\begin{array}{l}\text { Driving } \\
\text { Conditions }\end{array}$} & \multicolumn{3}{|c|}{$\begin{array}{c}\text { Base-Case } \\
\mathrm{CO}_{2} \text {-Equivalent Emissions, } \\
\text { by Time Horizon (g/mi) }\end{array}$} \\
\hline & & & & 20) $\mathrm{yr}$ & $100 \mathrm{yr}$ & 5()() $\mathrm{yr}$ \\
\hline Gaso & LDV & 30 & City/hi & 633.6 & 491.2 & 449.2 \\
\hline Dicsel & HDV & 6 & Truck test cycle & $3,819.3$ & $2,627.1$ & $2,331.4$ \\
\hline Gasoline & LDV & 24.5 & City only & 727.7 & 577.1 & 533.1 \\
\hline
\end{tabular}

Battery-powered electric vehicles (EVs) are compared with 24.5-mpg gasoline velhicles; all other alternatives are compared with 30-mpg gasoline vehicles. Note that the 10()-year values are the same as those from Table 9. In all scenarios in which the variables being tested do not significantly affect the petroleum fuel cycle, these "original" base-case values become the bascline values against which the alternatives are compared.

However, in several scenarios, the variables being tested also significantly affect the petroleum-fuel base case. These variables include (a) the rate of venting of $\mathrm{CH}_{4}$ from coal mincs, (b) the efficiency of coal-fired and gas-fired power plants, (c) the amount of non- $\mathrm{CO}_{2}$ greenhouse gas emissions from coal- and gas-fired power plants, (d) the extent of NG leaks from gas distribution systems, (e) the energy intensity of mining and enriching uranium, and ( $f$ ) the energy intensity of NG recovery and processing. When I changed the values for these variables for a scencrio analysis, I also changed the values in the gasoline or diesel-fuel baselines, against which the alternatives were compared, unless I intentionally "froze" the baselines at their original base-case values. I generally allowed the petroleum-fuel baseline to change in response to changes in input variables because it allows for an internally consistent comparison and makes the analysis casier $t o \mathrm{do}$. 
TABLE 12 (Cont'd)

The scenarios in which the petroleum-fuel baseline is affected, and the corresponding changed $\mathrm{g} / \mathrm{mi}$ results for the petroleum baseline (against which the alternatives are then compared), are as follows:

\begin{tabular}{|c|c|c|c|}
\hline \multirow[b]{2}{*}{ Sceriario } & \multicolumn{3}{|c|}{$\begin{array}{l}\text { Revised Baseline Values } \\
\text { for } \mathrm{CO}_{2} \text {-Equivalent Emissions, } \\
\text { by Time Horizon }(\mathrm{g} / \mathrm{mi})\end{array}$} \\
\hline & $20 \mathrm{yr}$ & $100 \mathrm{yr}$ & $500 \mathrm{yr}$ \\
\hline 4 (except EVs) & 490.0 & 452.5 & 435.6 \\
\hline $4(\mathrm{EVs})$ & 575.1 & 535.8 & 518.4 \\
\hline 5 & $2,326.8$ & $2,227.8$ & $2,191.5$ \\
\hline 6 & 600.2 & 559.1 & 541.2 \\
\hline 7 & & 404.0 & \\
\hline 8 & & $2,128,2$ & \\
\hline 15 & 841.6 & 535.8 & 453.8 \\
\hline 16 & $6,697.6$ & $3,376.0$ & $2,577.3$ \\
\hline 17 (except Japarı) & 932.4 & 618.5 & 534.4 \\
\hline $18-\mathrm{c}$ & & 489.8 & \\
\hline $18-i$ & 630.4 & 490.1 & 448.9 \\
\hline $18-j$ & 633.8 & 491.4 & 449.6 \\
\hline $19-a$ & & $2,627.0$ & \\
\hline 19-e & $3,823.4$ & $2,632.8$ & $2,338.7$ \\
\hline 19-f & $3,818.5$ & $2,627.1$ & $2,332.4$ \\
\hline $20-\mathrm{a}$ & & 496.3 & \\
\hline $20-c$ & & 489.2 & \\
\hline 2()$-d$ & 635.0 & 495.1 & 453.8 \\
\hline $20-f$ & & 488.9 & \\
\hline $21-a$ & & $2,627.1$ & \\
\hline $21-b$ & $3,807,9$ & $2,623.7$ & $2,330.7$ \\
\hline $23-u$ & & 494.6 & \\
\hline $24-\mathrm{c}$ & & $2,638.3$ & \\
\hline $29-0$ & & 576.7 & \\
\hline $29-q$ & & 563.5 & \\
\hline $29-r^{4}$ & & 562.8 & \\
\hline $29-v, w$ & & 576.3 & \\
\hline $29-x$ & & 546.3 & \\
\hline 29-аa & & 580.0 & \\
\hline $30-c, g$, and $h$ & & 49() .8 & \\
\hline
\end{tabular}

In most other scenarios, the petroleum baseline either is not affected significantly or is intentionally frozen at its "original" base case value. The baseline values in some of the methanol scenarios (18-c, $i, j$ ) change because $I$ assume that the methanol in the MTBE in gasoline is made from the same feedstock, and by the same process, as is the methanol used as a fuel. The baseline values in the EV scenarios change because the power plants that supply EV batteries also supply the petroleum-fuel cycle. 
These are full descriptions of the abbreviated forms used in the Description column of the table to describe the alternative vehicle types and fuels considered in the analysis. $L D=$ light-duty; $\mathrm{HD}=$ heavy duty; ICEV = internal-combustion-engine vehicle; $\mathrm{EV}=$ electric-motor-driven vehicle powered by a battery; and fuel cell = electric-motor-driven vehicle running on a fuel cell. If EV or fuel cell is not specified, the vehicle is assumed to be an ICEV. LDVs or HDVs refer to all light-duty vehicles or heavy-duty vehicles, respectively, whether they are ICEVs, EVs, or fuel-cell vehicles.

Abbreviated Form

Standard gasoline
Methanol/NG
Methanol/coal
CNG
LNG
Marginal U.S. mix/EV

Ethanol/corn+coal

Hydride/nuclear electrolysis

$\mathrm{LH}_{2}$ / nuclear electrolysis

LPG/oil and NG

Methanol/wood

CSNG/wood

Ethanol/wood

Hydrogen/all-solar

\begin{abstract}
All-solar/EV
Methanol/NG/fuel cell

Methanol/coal/fuel cell

Methanol/wood/fuel cell

Hydride/nuclear electrolysis/ fuel cell
\end{abstract}

Hydrogen/all-solar/fuel cell

\section{Full Description}

ICEV running o I gasoline that is not reformulated ICEV running on methanol derived from natural gas

ICEV running on methanol derived from coal ICEV running on compressed natural gas

ICEV $m_{i}$ nning on liqueficd natural gas

Battery-powered electric vehicle recharged with the "marginal" U.S. power mix; i.e., the mix used by EVs specifically

ICEV running on ethanol derived from corn by using coal as process fuel

ICEV running on compressed hydrogen that was electrolyzed from water with nuclear power and compressed with year-2000) power mix

ICEV running on liquefied hydrogen that was electrolyzed from water with nuclear power and liquefied with year-2000) power mix

ICEV running on liquefied petroleum gas derived from oil and natural gas

ICEV running on methanol derived from wood

ICEV running on compressed synthetic natural gas derived from wood

ICEV running on ethanol derived from wood

ICEV running on hydrogen electrolyzed from water with solar power and compressed or liquefied with solar power

EV recharged with solar power

Fuel cell vehicle powered by methanol derived from natural gas

Fuel cell vehicle powered by methanol derived from coal

Fuel cell vehicle powered by methanol derived from wood

Fucl cell vehicle powered by compressed hydrogen that was electrolyzed from water with nuclear power and compressed with year-200)( power mix

Fuel cell vehicle powered by hydrogen electrolyzed from water with solar power and compressed or liquefied with solar power

${ }^{\mathrm{b}} \mathrm{A}$ change of $\mathrm{X} \%$ means that total fuel-rycle emissions (in grams per mile) from the alternative-fuel vehicle are equal to those from the baseline petroleum-fuel vehicle multiplied by $1+(\mathrm{X} / 10())$ ). 'The baseline $\mathrm{g} / \mathrm{mi}$ values for the petroleum-fuel cycles were shown in footnote a. To calculate the percentage change relative to any other bascline (such as standard gasoline, fuel-cycle emissions 
TABLE 12 (Cont'd)

excluding emissions from vehicle and materials manufacture and assembly, or the "high" case for reformulated gasoline (Scenario 12-f)), use the following formula:

where:

$$
\mathrm{Pn}=-100 \times\{1-\mid \mathrm{Bo} / \mathrm{Bn} \times(1+\mathrm{Po} / 100)]\}
$$

$\mathrm{Pn}=$ change for the alternative-fuel vehicle scenario of interest relative to the new baseline Bn (expressed as a percentage),

$\mathrm{Bo}=$ old baseline (reformulated gasoline or low-sulfur diesel fucl) emission rate $(\mathrm{g} / \mathrm{mi})$,

$\mathrm{Bn}=$ new baseline (such as standard gasoline) emission rate $(\mathrm{g} / \mathrm{mi}$ ), and

$P_{0}=$ change for the alternative-fucl vehicle scenario of interest relative to the original baseline (expressed as a percentage).

"Basc-case alternative-fuel LDV and HDV scenarios show the results of running the model with all the base-case assumptions, under the three different time horizons. The results shown under the "10(1)-year" column are the same as those shown in lable 9.

${ }^{d}$ See App. $R$ for a discussion of the changes made to model Europe and Japan.

See App. B for explanation of method used to estimate emissions from fuel-cell vehicles. 


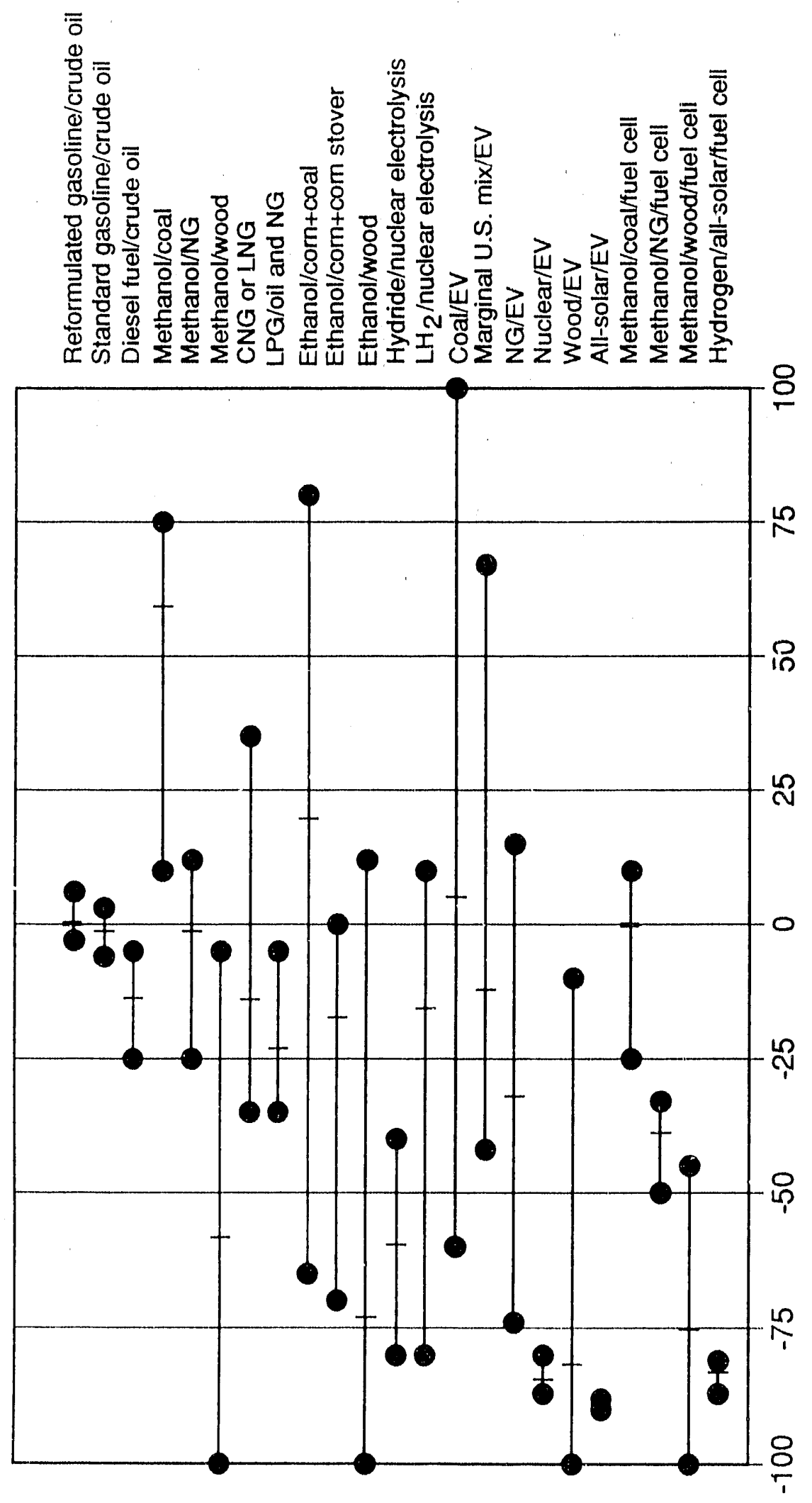

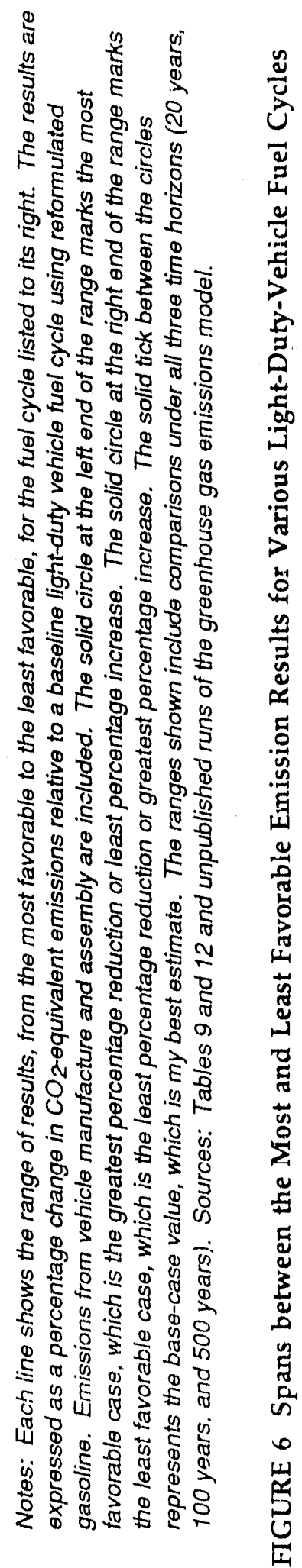




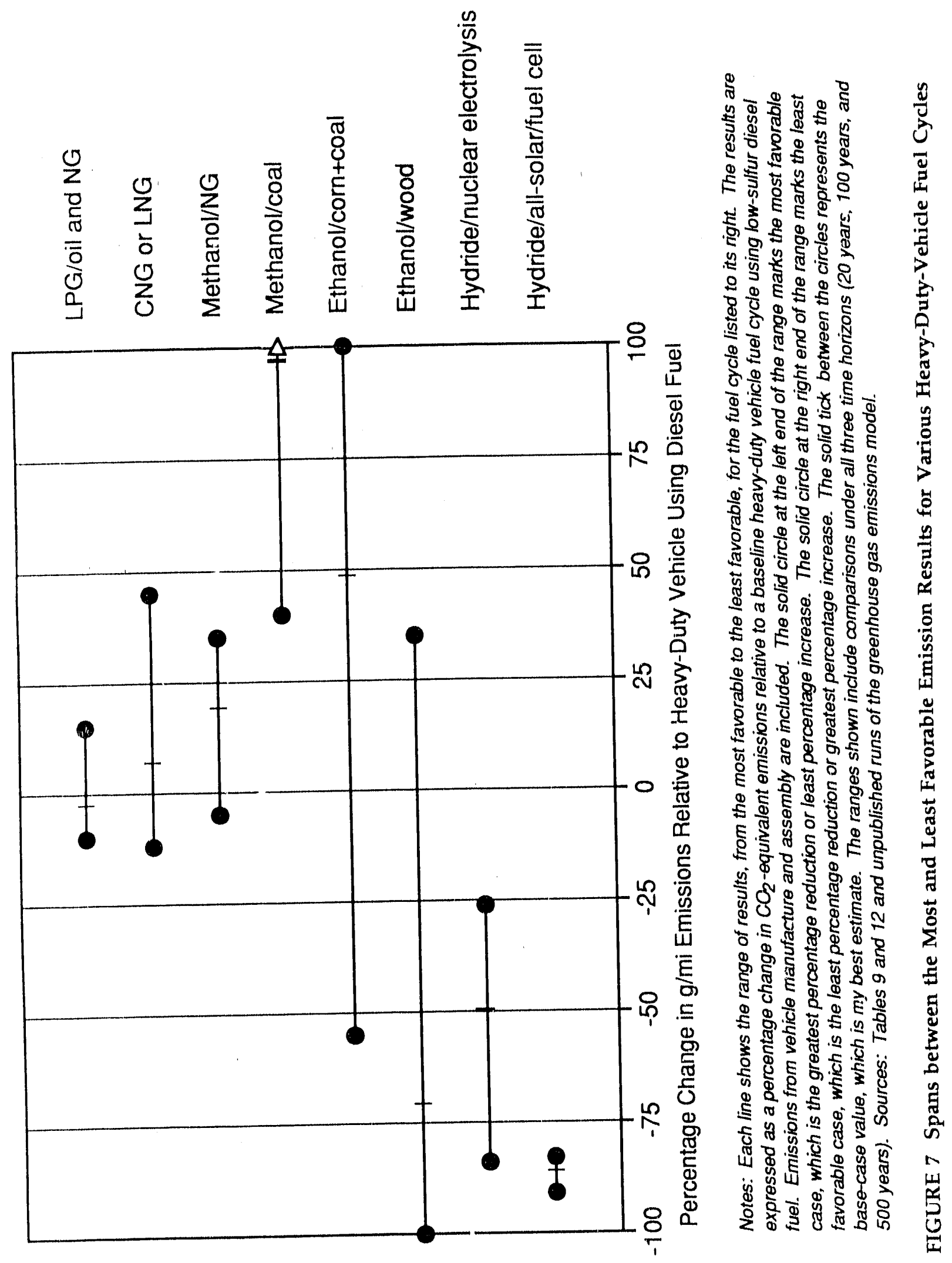


C'icle. The 20-year and 100-year $\mathrm{N}_{2} \mathrm{O}-\mathrm{to}-\mathrm{CO}_{2}$ conversion factors are nearly equal, but thie 500-year factor is much lower; hence, for ethanol from corn, there is a large difference between the 500-year result and the 100-year and the 20-year results.

Third, the more that non- $\mathrm{CO}_{2}$ greenhouse gases contribute to total fuel-cycle emissions, the more important the time horizon is in determining the final $\mathrm{g} / \mathrm{mi}$ emission total. This situation occurs because the time horizon determines the relative importance of the non- $\mathrm{CO}_{2}$ greenhouse gases. Thus, total fuel-cycle $\mathrm{g} / \mathrm{mi}$ emissions from CNG vehicles depend, for example, on how heavily the relatively large amount of $\mathrm{CH}_{4}$ emitted from the tailpipe is weighted. Total fuel-cycle emissions from vehicles running on corn-derived ethanol depend on how heavily the $\mathrm{N}_{2} \mathrm{O}$ emissions from fertilizer are weighted.

In a similar fashion, a substantial difference in the relative importance of non$\mathrm{CO}_{2}$ greenhouse gases to total emissions between an alternative-fuel cycle and the petroleum-fuel cycle can affect how the alternative fuel compares with the petroleum fuel at different time horizons. For example, the percentage reduction in emissions provided by methanol-based fuel-cell vehicles (when the methanol is derived from coal or NG) decreases over longer time horizons, because the fuel cycle of a fuel-cell vehicle emits a moderate amount of $\mathrm{CO}_{2}$ but very little non- $\mathrm{CO}_{2}$ greenhouse gases, while the fuel cycle of a gasoline vehicle emits a substantial amount of both $\mathrm{CO}_{2}$ and non- $\mathrm{CO}_{2}$ gases. Since non- $\mathrm{CO}_{2}$ emissions are responsible for a larger share of total gasoline-fuel-cycle emissions than of total fuel-cell-cycle emissions, the down-weighting of the non- $\mathrm{CO}_{2}$ emissions in the longer time horizon confers more of an advantage on gasoline. On the other hand, the percentage reduction provided by methanol-based fuel-cell vehicles in cases where the methanol is derived from biomass rather than from coal or NG increases with longer time horizons. This result occurs because the biofuel cycle produces very little $\mathrm{CO}_{2}$ as well as very little nun- $\mathrm{CO}_{2}$ gases. In fact, the biofuel cycle produces so little $\mathrm{CO}_{2}$ that non- $\mathrm{CO}_{2}$ gases, even though minor, are slightly more important in the biofuel cycle than in the gasoline cycle.

The fourth result is represented by the 20-year case for SNG from wood, which offers only a modest reduction in emissions of greenhouse gases. This result indicates that the use of wood as a feedstock does not automatically greatly reduce fuel-cycle emissions of greenhouse gases. In this case, the benefit of using wood has been greatly eroded by the use of fossil-fuel-based electricity to compress $\mathrm{CNC}^{3}$, by the heavy weighting of emissions of non- $\mathrm{CO}_{2}$ greenhouse gases that occurs over the short-term horizon, and by leaks of SNG from pipelines. Moreover, compressed SNG vehicles in this analysis have about half the driving range of regular CNG vehicles, because SNG is a medium-Btu gas. 


\subsection{SCENARIOS 4, 5, AND 6}

In these scenarios, $\mathrm{NO}_{x}$ emissions are excluded, and NMOC emissions are considered only with respect to their oxidation to $\mathrm{CO}_{2}$. As shown in Table 8, the IPCC (Shine et al, 1990) has estimated that a gram of $\mathrm{NO}_{x}$ has 14-150 times the warning potential of a gram of $\mathrm{CO}_{2}$, and a gram of carbon in an NMOC has 7 to 36 times the warming potential of $\mathrm{CO}_{2}$. Therefore, together, $\mathrm{NO}_{x}$ and $\mathrm{NMOC}$ emissions could account for a large fraction of total fuel-cycle, $\mathrm{CO}_{2}$-equivalent emissions. Nevertheless, $\mathrm{NO}_{x}$ and NMOC emissions contribute to global warming only indirectly, through a series of chemical reactions that can lead to an increase in the concentration of tropospheric ozone. The atmospheric chemistry of ozone formation and the greenhouse behavior of tropospheric ozone are quite complex, making it difficult to estimate $\mathrm{CO}_{2}$-equivalency factors for $\mathrm{NO}_{x}$ and $\mathrm{NMOCs}$. Therefore, because $\mathrm{NO}_{\mathrm{x}}$ and NMOC equivalency factors are both important and uncerlain, and because different fuel cycles emit different amounts of $\mathrm{NO}_{x}$ and NMOCs, the emissions model excludes the ozone-forming effect of $\mathrm{NO}_{x}$ and NMOCs under Scenarios 4-6. It does so by assuming that the equivalency factor for $\mathrm{NO}_{x}$ is zero (i.e., $N \mathrm{O}_{x}$ is "zeroed out"), and by treating NMOCs as having no warming effect other than oxidizing to $\mathrm{CO}_{2}$.

Scenarios 4-6 of Table 12 show the results of rerunning the base case with the changes described above. The alternative-fuel cycles in which $\mathrm{NO}_{\mathrm{x}}$ emissions are relatively important benefit the most (compare Scenarios 4-6 with 1-3). This benefit is most pronounced over the 20-year time horizon, because the $\mathrm{NO}_{x}$ has a huge warming effect in the 20-year case because of its very high equivalency factor (150; see Table 8). This benefit is strikingly illustrated in the 20-year case for biofuel HDV fuel cycles (compare Scenario 5 with 2). The percentage reduction provided by biofuel HDVs increase's by about $40 \%$ in absolute percentage points in the 20-year case, when $\mathrm{NO}_{x}$ emissions are excluded. This extraordinary improvement occurs because in the 20-year base case, $\mathrm{NO}_{\mathrm{x}}$ emissions from the tailpipes of biofuel HDVs actually account for the bulk of total fuel-cycle, $\mathrm{CO}_{2}$-equivalent emissions, (Given $8.05 \mathrm{~g} / \mathrm{mi} \mathrm{NO}$ [Table B.2] and an equivalency factor of 150 [Table 8], $\mathrm{NO}_{\mathrm{x}}$ emissions amount to $1,208 \mathrm{~g} / \mathrm{mi}$, which is about $50 \%$ of total $\mathrm{CO}_{2}$-equivalent emissions in the 2()-year case.) Eliminating $\mathrm{NO}_{x}$ emissions thus reduces $\mathrm{CO}_{2}$-equivalent emissions from the biofuel cycle to nearly zero and greatly improves its relative standing. The effect is not as pronounced in the 100-year case but is still large.

In general, all fuel cycles that have very small amounts of $\mathrm{CO}_{2}$ emissions per se (e.g., biofuel cycles and hydrogen cycles) look better when $\mathrm{NO}_{x}$ and NMOCs are excluded, and, given this exclusion, look better the longer the horizon is. This result occurs because non- $\mathrm{CO}_{2}$ greenhouse gases are more important in these fuel cycles than in fuel cycles that produce a lot of $\mathrm{CO}_{2}$.

The ethanol-from-corn cycle also looks much better when $\mathrm{NO}_{x}$ and NMOCs are excluded. In fact, in the 500-year case, the ethanol-from-corn fuel cycle results in only a slight increase in $\mathrm{CO}_{2}$-equivalent emissions (compared with gasoline). The 
ethanol-from-corn fuel cycle has several sources that contribute a large amount of $\mathrm{NO}_{x}$ emissions: vehicles, ethanol-making fadilties (which burn coal), and firtilizar' nitrification. When these $\mathrm{NO}_{x}$ emissions are excluded, ethanol's sianding improves.

The LPG, CNG, and EV fuel cycles are relatively unaffected by the exclusion of $\mathrm{NO}_{x}$ and NMOCs. The methanol fuel cycle improves slightly, in part because of the exclusion of the relatively large $\mathrm{NO}_{x}$ emissions from methanol facilitics (see Table A.1; this estimate needs to be corroborated, however).

The general conclusion of these scenarios is that, to the extent that the $\mathrm{NO}_{x}$ equivalency factor is too high, emissions from biofuel and hydrogen fuel cycles look worse than they should.

\subsection{SCENARIOS 7 AND 8}

These scenarios compare total fuel-cycle emissions of $\mathrm{CO}_{2}$ only; NMOCs, $\mathrm{CH}_{4}, \mathrm{CO}, \mathrm{NO}_{x}$, and $\mathrm{N}_{2} \mathrm{O}$ have been "zeroed out." Virtually all the alternatives look much bettar when non- $\mathrm{CO}_{2}$ greenhouse gases are excluded. Some alternatives benefit dramatically. Ethanol from corn is one that does, because much of the greenhouse impact of ethanol from corn is from $\mathrm{N}_{2} \mathrm{O}$ and $\mathrm{NO}_{\mathrm{x}}$. All the wood fuels benefit as inell, because they have very low $\mathrm{CO}_{2}$ emissions, especially when they are given a $\mathrm{CO}_{2}$ credit for emissions of non- $\mathrm{CO}_{2}$ organic species. (The results shown give a $\mathrm{CO}_{2}$-removal credit for the carbon in all $\mathrm{CO}, \mathrm{CH}_{4}$, and $\mathrm{NMOC}$ emissions from the wood fuel cycles, but give zero weight to the $\mathrm{CO}, \mathrm{CH}_{4}$, and NMOC emissions themselves.) $\mathrm{NG}$ vehicles look modestly better in the $\mathrm{CO}_{2}$-only scenario, because of the low carbon/Btu content of NG. LPG rates the same in the $\mathrm{CO}_{2}$-only scenario as in the all-gases scenario, because the emissions-reduction benefit of $1 . P C$ is distributed fairly evenly over $\mathrm{CO}_{2}$ and non- $\mathrm{CO}_{2}$ gases.

\subsection{SCENARIOS 9 AND 10}

These high-efficiency scenarios examine how greatly increasing the relative efficiency of alternative-fuel vehicles affects greenhouse gas emissions. I assume that alternative-fuel LDVs have a $20-30 \%$ thermal efficiency advantage over gasoline LDVs and that alternative-fuel HDVs suffer little or no efficiency loss relative to diesel HDVs. I group all the ICEVs into one scenario because some of the most effective efficiency-improving technologies apply to most or all of the vehicles, and because all LDVs face the same constraint on efficiency improvements: the tight $\mathrm{NO}_{x}$ standard, which may foreclose the use of lean-burn technology.

As expected, the higher efficiency and lower emissions of CO, NMOCs, and $\mathrm{CH}_{4}$ that result from the use of lean-burn technology markedly reduce total greenhouse gas emissions in almost every case. Most of the alternative-fuel cases improve by approximately 10 percentage points relative to the petroleum-fuel 
bascline. The emission reductions are largest for methanol from NG and ethanol from corn, because the assumed efficiency gains are largest. The ethanol-from-wood cuse shows only a small reduction in total fuel-cycle, $\mathrm{CO}_{2}$-equivalent greenhouse gins emissions because the vast portion of total emissions in this case consists of emissions from vehicle manufacture and non- $\mathrm{CO}_{2}$ emissions from the tailpipe of the vehicle, both of which are independent of fuel economy. Consequently, there is little opportunity for effictency improvement (the major benefit of lean-burn technology) to have an effect.

\subsection{SCENARIO 11}

This scenario compares the emissions from dual-fuel or flexible-fuel LDVs operating on the alternative fuels M85, M50, CNG, LPG, or E85 with the emissions from comparable single-fuel (dedicated) velicles operating on only reformulated gatoline. A dual-fuel vehicle has two separate fuel storage and delivery systems; it can operate on either gasoline or the alternative fuel but not on a mixture of them. CNC/gasoline and $\mathrm{LPG} /$ gasoline vehicles are dual-fuel vehicles. A flexible-fuel vehicle (FFV) has one fuel storage and delivery system; it can operate on either gasoline or the alternative fuel or on any mixture of gasoline and the alternative fuel. Alcohol/gasoline vehicles are flexible-fuel vehicles. Alcohol FFVs are assumed to use $85 \%$ alcohol and $15 \%$ reformulated gasoline.

Alcohol FFVs are slightly more efficient than comparable dedicated gasoline vehicles. They generate a somewhat greater amount of tailpipe NMOC emissions than do dedicated methanol vehicles becacise of the gasoline that is added to the fuel (Sperling and DeLuchi, 1991; EPA, Analysis of the Economic and Environmental Effects of Ethanol as an Autumotine Fuel, 1990); EPA, Amalysis of the Economic and Envirommental liffects of Methanol as an Automotive I"Ucl, 1989). FFV evaporative emissions are also grenter, because the addition of gasoline increases the vapor pressure over that of a pure alcohol. However, future FFV operaling on alcohol (M85 or M100) will emit le'ss $\mathrm{NO}_{x}$ than will dedicated gasoline or methanol vehicles. This result will occur because these FFVs, when running on gasoline, will be designed to emit the same level of $\mathrm{NO}_{x}$ as dedicated alcohol or gasoline vehicles because they will all have to meet the same $\mathrm{NO}_{x}$ standards under the Clean Air Act Amendments. Given a particular pollution control system and engine design, an FFV operating on alcohol will have a smaller amount of $\mathrm{NO}_{x}$ emissions than an FFV operating on gasoline (and hence a smaller amount of $\mathrm{NO}_{x}$ emissions than a dedicated methanol or gasoline vehicle) because of the lower flame temperature, faster speed, and higher latent heat of vaporization of alcohol (Sperling and Deluchi, 1991).

In the case of the alcohols, emissions from the upstream gasoline productionand-transport processes are weighted by the contribution of gasoline to the total encrgy of the fuel mixture. Emissions from the upstream alcohol production-andtransport processes are weighted by the contribution of alcohol to the total energy of the fuel mixture. 
In the case of $\mathrm{E85}$, tallpipe emissions of $\mathrm{CO}_{2}$ from the combustion of the ethanol are ignored (because the ethanol is derived from biomass), and tailpipe emissions of non- $\mathrm{CO}_{2}$ organic gases from the combustion of the ethanol portion of the mixture are given a $\mathrm{CO}_{2}$ removal credit. All emissions $\left(\mathrm{CO}_{2}\right.$ and non- $\left.\mathrm{CO}_{2}\right)$ from the combustion of the gasoline portion of the mixture are counted at their full global warming potential. Total tallpipe emissions of $\mathrm{CO}, \mathrm{CH}_{4}$, and NMOCs are assigned to gasoline or ethanol on the basis of the contribution of each fuel to the total carbon content of the mixture.

I assume that dual-fuel NG or LPG vehicles, when operated on LPG or NG, have the same thermal efficiency as comparable dedicated gasoline vehicles. I assume they have the same $\mathrm{NO}_{\mathrm{x}}$ and $\mathrm{CO}$ emissions but slightly higher $\mathrm{CH}_{4}$ and NMOC emissions than dedicated NG and LPG vehicles. I also assume that the dualfuel gaseous-fuel vehicles have a shorter range when they run on CNG or LPG than do dedicated CNG or LPG vehicles, an assumption that is consistent with actual practice. However, I assume that both the dual-fuel LPG and the dual-fuel NG vehicles have a gasoline tank, which adds to the total weight of the vehicles and reduces efficiency.

The results show that dual-fuel vehicles fare worse than dedicated vehicles, primarily because of their lower thermal efficiency. FFVs using $85 \%$ ethanol from wood fare considerably worse than dedicated ethanol vehicles, not only because of their lower efficiency but because of the $\mathrm{CO}_{2}$ emissions from the $15 \%$ gasoline portion of the mixture (Scenario 11-g), which are not canceled by $\mathrm{CO}_{2}$ uptake in the way that $\mathrm{CO}_{2}$ emissions from biofuels are. Ethanol from corn does not do as poorly under this scenario as does ethanol from wood, because the emissions from the combustion of gasoline in the vehicle are balanced somewhat by the fact that the production and transport of the gasoline produces a much smaller amount of greenhouse gases than does the production and transport of the ethanol replaced by the gasoline (Scenario 11-e).

Greenhouse gas emissions from an FFV decline very slightly as the methanol content of the mixture declines (Scenario 11-a versus 11-c). This situation occurs because the small improvement in efficiency and the reduction in $\mathrm{NO}_{x}$ emissions (relative to gasoline operation) gained by adding methanol is slightly more than offset by the greater upstream emissions from methanol manufacture than from gasoline manufacture. If the FFV could take full advantage of the efficiencyimproving potential of methanol, this would not be the case.

\subsection{SCENARIO 12}

This scenario examines the effect of varying the values of some of the more uncertain input variables from those assumed in the gasoline base case. Results somewhat surprisingly reveal that the uncertainty in the variables examined is relatively unimportant, at least over the ranges considered. For example, ceven if 
refinery energy requirements were 0.20 instead of $0.182 \mathrm{Btu}$ of process energy per Btu of gasoline, total fuel-cycle, $\mathrm{CO}_{2}$-equivalent emissions would increase by only $1.2 \%$ in the 100-year scenario (Scenario 12-a). In another example, if, because of the extensive use of low-quality crude and enhanced oil recovery, it would take $25 \%$ more energy than estimated in the base case to recover crude oil, total fuel-cycle, $\mathrm{CO}_{2}$-equivalent emissions would increase by only $0.6 \%$ over the base case (Scenario 12-b). Increasing per-barrel emissions from venting and flaring by $25 \%$ and assuming that $10 \%$ rather than $6 \%$ of the gas is vented rather than flared would increase total emissions by only $0.5 \%$ (Scenario 12-c). Assuming that reformulated gasoline would provide no reduction in tailpipe emissions of $\mathrm{CO}$ and NMOCs would increase total greenhouse gas emissions by $0.4 \%$ (Scenario 12-d). Finally, if crude input were not reduced as a resuli of using MTBE, and if part of the extra crude available were used as refinery fuel, emissions would be only $0.2 \%$ higher than they are in the base case, because the increase resulting from not displacing the crude would be nearly canceled by the decrease resulting from using refinery gas instead of purchased NG (Scenario 12-e).

Even if all the uncertain variables examined here were simultaneously higher than in the base case, the result would still only be a $2.9 \%$ increase in total fuel-cycle, greenhouse gas emissions in the 100-year case (Scenario 12-f). The increase would be larger in the 20-year case because of the heavier weight given to the extra vented gas and the extra tailpipe emissions. This uncertainty analysis leads one to the tentative conclusion that the estimates here are accurate to within $5 \%$.

\subsection{SCENARIO 13}

The reduction in greenhouse gas emissions provided by diesel vehicles depends somewhat on the relative fuel economy of the vehicle. If diesel LDVs were to have only $20 \%$ better fuel economy than gasoline LDVs (36 mpg versus $30 \mathrm{mpg}$ on reformulated gasoline and $30.7 \mathrm{mpg}$ on standard gasoline), which is at the low end of the range reported for current diesel vehicles, their operation would result in a $10 \%$ reduction in total fuel-cycle, $\mathrm{CO}_{2}$-equivalent emissions (Scenario 13-b). On the other hand, ultra-efficient technologies, like direct injection coupled with turbocharging, could allow for an improvement of more than $40 \%$ in fuel economy and would result in a reduction of nearly $20 \%$ in total fuel-cycle, $\mathrm{CO}_{2}$ equivalent emissions (Scenario 13c). In the best case, diesel LDVs could rival LPG vehicles as having the lowest-greenhouse-gas-emitting fuel cycles of all ICEVs (Scenario 13-d). Battery-powered EVs that run on electricity supplied by advanced NG-fired turbines or by NG fuel cells would have lower emissions.

Allowing the sulfur content of diesel fuel to remain at current levels would provide only a minor greenhouse gas benefit (compare Scenario 13-e with 13-a). This situation would occur because, in any case, emissions from the refinery are only a small portion of the total emissions in a diesel fuel cycle, and low-iulfur 
diesel fuel would require only a small increase in energy to manufacture over current diesel fuel.

\subsection{SCENARIO 14}

Although most heavy-duty trucks use diesel fuel, some do use gasoline, and alternative fuels may replace gasoline in heavy-duty applications. This scenario allows for an indirect comparison between alternative-fuel HDVs and gasoline HDVs, by directly comparing diesel HDVs and gasoline HDVs.

Gasoline HDVs emit much greater amounts of greenhouse gases per mile than do diesel HDVs, because of the much lower thermal efficiency of the spark-ignition engine. Depending on the efficiency loss and the time horizon, gasoline LDVs can have 10-35\% higher total fuel-cycle, $\mathrm{CO}_{2}$-equivalent emissions per mile than do diesel HDVs. In Scenarios 14-a and b, the relative standing of gasoline HDVs is very sensitive to the time horizon, because of the considerable amount of $\mathrm{NO}_{\mathrm{x}}$ emitted from HDVs. If these $\mathrm{NO}_{x}$ emissions were not counted (Scenario 14-c), two interesting results would occur. First, the gasoline HDV would fare even worse, because its one main advantage over the diesel HDV -- lower $\mathrm{NO}_{x}$ emissions -would no longer be effective. In fact, not counting $\mathrm{NO}_{\mathrm{x}}$ emissions is worse for the gasoline HDV than is reducing its fuel economy from 4.8 to $4.5 \mathrm{mpg}$. Second, the influence of the time horizon would be reversed: with $\mathrm{NO}_{x}$, the gasoline vehicle would fare better the shorter the time horizon; without $\mathrm{NO}_{\mathrm{x}}$, the reverse would be true. Thus, these results show, once again, the potentially great importance of non$\mathrm{CO}_{2}$ greenhouse gases in total emission results.

This analysis reveals one more noteworthy result. Changing from gasoline to diesel fuel causes more of a percentage reduction in emissions for HDVs than LDVs at any given percentage of fuel economy improvement. (Convert the results here to a gasoline-to-diesel basis, by taking the reciprocal; then compare these results with the gasoline-to-diesel results of Scenario 13.) This situation occurs because fuel economy improvements affect $\mathrm{CO}_{2}$ emissions, and $\mathrm{CO}_{2}$ emissions constitute a larger percentage of total greenhouse gas emissions from low-mpg vehicles than from high-mpg vehicles.

\subsection{SCENARIOS 15 AND 16}

These scenarios compare emissions from alternative-fuel vehicles with emissions from future gasoline vehicles in Europe. In these scenarios, I respecify (1) emission factors for gasoline and diesel vehicles and for power plants and petroleum refineries, (2) the mix of fuels used by petroleum refineries, (3) enissions from coal mining, (4) the efficiency of power plants, (5) the mix of fuels used by power plants, (6) the geographic distribution of major electricity-consuming 
activities, and (7) transportation patterns for oil and coal, to represent Europe in the year 2000. These changes are detailed in App. R.

I establish two scenarios for the alternative-fuel vehicles: (1) they operate at stoichiometry, use a three-way catalyst, and are moderately more thermally efficient than comparable gasoline vehicles; and (2) they use lean-burn technology, are much more thermally efficient than the comparable gasoline vehicle, and have lower $\mathrm{CO}$ and NMOC emissions than in the stoichiometry scenario. Since the new European $\mathrm{NO}_{x}$ standard is not as stringent as the new U.S. Clean Air Act $\mathrm{NO}_{\mathrm{x}}$ standard, it is more likely that alternative-fuel vehicles will be able to use lean-burn technology in Europe than in the United States.

The European stoichiometric case is not dramatically different from the U.S. base case. This result occurs because the higher tailpipe emissions in Europe, which tend to make the alternative-fuel vehicles look somewhat better, are partly offset by lower emissions from the refining stage for gasoline (that result primarily from lower refinery energy requirements), which tends to make gasoline vehicles look better.

The lean-burn case noticeably improves the emissions standing of the alternative-fuel vehicles relative to gasoline vehicles. In most cases, the alternativefuel vehicles show an improvement of 5 to 10 absolute percentage points. Thus, the relatively lax $\mathrm{NO}_{x}$ standard in Europe may make alternative-fuel vehicles more attractive, from a greenhouse standpoint, than they would be in the United States, because of the possibility of using lean-burn technology.

The HDV analysis for Europe differs sharply from the HDV analysis for the United States: alternative-fuel HDVs fare much better than diesel HDVs in Europe than in the United States (compare Scenario 16 with 2). For example, in Europe, methanol and CNG HDVs are projected to have lower greenhouse gas emissions than diesel HDVs, whereas in the United States, they are projected to have higher emissions. Similarly, ethanol HDVs cause less of an increase in greenhouse gas emissions in the European case than in the U.S. case.

However, this HDV analysis for Europe should be viewed with caution, and even skepticism, because it is driven almost entirely by the IEA's (1991) projection of very high $\mathrm{NO}_{\mathrm{x}}$ emissions -- $27.40 \mathrm{~g} / \mathrm{mi}$-- from future diesel HDVs in the European Economic Community (EEC). With emissions of $27 \mathrm{~g} / \mathrm{mi}$ and a $\mathrm{CO}_{2}$-emission equivalency factor of 40 (for the 100-year time horizon), $\mathrm{NO}_{\mathrm{x}}$ from the tailpipe would account for about one-third of total fuel-cycle, $\mathrm{CO}_{2}$-equivalent emissions. For the 20-year time horizon, $\mathrm{NO}_{\mathrm{x}}$ from the tailpipe of diesel HDVs would account for nearly two-thirds of total emissions! Since I have assumed that alternative-fuel HDVs will have significantly less $\mathrm{NO}_{\mathrm{x}}$ emissions than diesel HDVs, it follows that the assumptions about $\mathrm{NO}_{\mathrm{x}}$ emissions are extremely important in the final results. Unfortunately, the calculation of the impact of $\mathrm{NO}_{x}$ is as uncertain as it is important. As discussed in App. $\mathrm{O}$, the equivalency factor for $\mathrm{NO}_{\mathrm{x}}$ is only preliminary. 
Moreover, the estimation of $\mathrm{NO}_{\mathrm{x}}$ emissions from future diesel and alternative-fuel HDVs is virtually impossible. The IEA (1991) projection of $\mathrm{NO}_{\mathrm{x}}$ emissions from diesel HDVs is itself questionable; however, even if it were totally accepted, it would still be very difficult to project relative $\mathrm{NO}_{x}$ emissions from alternative-fuel HDVs. Although they certainly have the potential to emit less $\mathrm{NO}_{\mathrm{x}}$ than do diesel HDVs, the extent to which this potential will be realized will depend on regulations, technology development, and tradeoffs between performance, emissions, and cost. Assumptions quite different from mine could be made.

The perhaps implausibly great importance of $\mathrm{NO}_{\mathbf{x}}$ emissions in the EEC scenario produces some interesting results. For example, in the U.S. base case, all the alternative-fuel HDV cases improve their standing relative to diesel HDV cases as the time horizon gets longer. In the U.S. base case, non- $\mathrm{CO}_{2}$ gases are relatively more important in the alternative-fuel cycles than in the diesel HDV cycle, and the longer time horizon "down-weights" non- $\mathrm{CO}_{2}$ gases. In the European case, however, $\mathrm{NO}_{\mathrm{x}}$ emissions from diesel HDVs dominate so much that non- $\mathrm{CO}_{2}$ gases are more important in the diesel HDV cycle than in some of the alternative-fuel HDV cycles; hence, some alternative-fuel vehicles fare better the shorter the time horizon. However, in Europe, alternative-fuel HDVs using wood fuels still fare better the longer the time horizon, because in the case of wood fuels, most of the emissions are non- $\mathrm{CO}_{2}$ gases. Nevertheless, the differences that occur (with wood-based fuels) over different time horizons are much less pronounced in Europe than the United States, because of the increased $\mathrm{NO}_{\mathrm{x}}$ emissions from the diesel HDVs in the European case.

Although the results shown here for diesel HDVs in Europe may not be meaningful, because of the dubiously large impact of $\mathrm{NO}_{x}$ and the difficulty of projecting $\mathrm{NO}_{x}$ emissions, they are nevertheless quite instructive: they show that assumptions about the magnitude and effectiveness of non- $\mathrm{CO}_{2}$ gases can drive the total emissions results.

\subsection{SCENARIO 17}

This scenario analyzes the use of EVs in Europe and Japan (see App. R for details). The use of EVs in Europe and Japan would substantially reduce $\mathrm{CO}_{2}$ equivalent emissions of greenhouse gases, although the greenhouse impact of EVs would vary considerably from country to country. The countries that rely the least on coal and other fossil fuels and use them most efficiently would show the greatest benefits. For example, in Sweden, Canada, and France, which would continue to rely heavily on nuclear or hydro power and not much on coal, the use of EVs would greatly reduce total $\mathrm{g} / \mathrm{mi}$ greenhouse gas emissions. In Germany and Great Britain, which would rely much more heavily on coal, the use of EVs would provide a smaller (but still large) reduction in emissions of greenhouse gases. 
In fact, the reductions in $\mathrm{g} / \mathrm{mi}$ emissions achieved through the use of EVs are strikingly large. Even in countries that use a lot of coal-based power, the reductions are much larger than they are in the United States. There are two main reasons for this. First, the IEA (1991) projections of emissions from gasoline LDVs in Europe are much higher than my comparable projections for the United States, primarily because the new U.S. emission standards for vehicles are much tighter than the new EEC emission standards (see App. R). These much higher tailpipe emissions of CO, $\mathrm{NMOC}, \mathrm{NO}_{x}$, and $\mathrm{CH}_{4}$, combined with higher evaporative emissions, greatly increase greenhouse gas emissions from the bas eline gasoline vehicle and make the EV look better. Conversely, the IEA (1991) projections of emissions from power plants in Europe are lower than my comparable projections of emissions for U.S. power plants, probably because in most European countries, $\mathrm{NO}_{x}$ emission limits are somewhat tighter than they are in this country (IEA, Emission Controls in Electricity Generation and Industry, 1988). Thus, the relatively lax tailpipe standards and relatively stringent power-plant standards make EVs more attractive in Europe.

\subsection{SCENARIOS 18 AND 19}

Total fuel-cycle, $\mathrm{CO}_{2}$-equivalent emissions from LDVs using NG-derived methanol can range from $11 \%$ higher to $22 \%$ lower than emissions from gasoline vehicles (Scenarios 18-i and $j$ ). The key factors are the time horizon, efficiency of the methanol engines (Scenarios 9-a and 18-h), efficiency of the NG-to-methanol plant (Scenario 18-a), amount of non- $\mathrm{CO}_{2}$ emissions from methanol vehicles and conversion plants (Scenarios 9-a and 18-d), and location of the gas feedstock (Scenarios 18-b and $c$ ). The efficiency and emissions variables are the most important; other variables, such as the rate of evaporative emissions (Scenario 18-f), and whether or not NGL is removed (Scenario 18-g), are less important. The location of the feedstock is important, because methanol made from remote gas would have to be transported thousands of miles by tanker to the United States, and this journey would produce a considerable amount of greenhouse gas emissions. Also, foreign plants would be less efficient than domestic plants because the feedstock gas would be cheaper.

If methanol vehicles could be operated lean and still meet the new $\mathrm{NO}_{x}$ standards (this is an important uncertainty), and if methanol could be made from relatively efficient domestic conversion plants, the emission reduction (compared with the gasoline baseline) would be in the range of $20 \%$. This scenario, then, can be viewed as representing the longer-term potential for methanol, relative to gasoline. However, in the short run, if methanol is made entirely from foreign NG and used in vehicles with an efficiency advantage of only $10 \%$, the use of NG-based methanol vehicle will cause a slight increase in greenhouse gas emissions.

If methanol were made from gas that would otherwise be flared, a very large reduction in $\mathrm{CO}_{2}$-equivalent emissions would result (Scenario 18-e), because any $\mathrm{CO}_{2}$ emissions from burning the methanol or the gas would not be a net emission. In 
other words, the $\mathrm{CO}_{2}$ would be emitted anyway from gas flaring, even if the gas were not converted to methanol.

At the present time, methanol HDVs are slightly less efficient than diesel HDVs, especially in city bus driving. This condition, when combined with the emissions that result from upstream methanol processes, makes for significantly higher emissions from the methanol HDV cycle than the diesel HDV cycle, in most cases. However, in the long-run, if methanol were to be made from domestic gas in efficient plants, and if HDVs were more efficient running on methanol than on diesel fuel, the methanol HDV cycle would not produce more emissions than the diesel HDV cycle (Scenario 19-e).

Overall, the use of methanol from NG will, in the long run, provide slight to moderate reductions in total fuel-cycle, $\mathrm{CO}_{2}$-equivalent emissions. The actual standing relative to the petroleum-fuel baseline will be determined by such things as emissions regulations, the cost and availability of NG, and the demand for fuel economy, as well as technical factors. Note, however, that a long-run methanol price that would support its large-scale production from domestic gas might also support its limited production from coal. And the overall greenhouse effect of a program using even a small amount of coal-derived methanol is likely to be negative (Scenarios 18-k and 19-g).

\subsection{SCENARIOS 20 AND 21}

This scenario shows that the use of methanol made from coal causes a significant increase in emissions of greenhouse gases, even if the vehicles and the coal conversion processes are very efficient. Even a combination of the most favorable assumptions -- coproduction of methanol from coal (using once-through methanol/liquid-phase methanol synthesis/integrated gasification combined cycle), very efficient methanol vehicles, and low $\mathrm{CH}_{4}$ emissions from coal mines -- still results in an increase in greenhouse gas emissions of more than 10\% for LDVs and of at least $40 \%$ for HDVs (Scenarios 20-d and 21-b). $\mathrm{CO}_{2}$ "disposal" (for example, by injection into depleted NG fields) can reduce emissions from the coal-to-methanol cycle to below those from the petroleum cycle (Scenarios 20-e and $f$ and 21-c and d), if it is assumed that making $\mathrm{CO}_{2}$ and then "disposing" of it is the same as not making it in the first place.

The use of only a small amount of coal-derived methanol could undo any emissions-reductions benefit achieved by using NG-derived methanol. The greenhouse gas impacts of long-run methanol strategies should be analyzed with this fact in mind. 


\subsection{SCENARIO 22}

Using methanol made from woody biomass that was grown using shortrotation intensive cultivation (SRIC) offers the prospect of substantially reduced greenhouse gas emissions (when compared with using petroleum fuels). In most of the following scenarios, the reduction ranges between $40 \%$ and $60 \%$. In the most favorable scenarios, the biomethanol cycle can reduce greenhouse gas emissions by more than 70\% from those in the petroleum-fuel scenario (Scenario 22-i). The most favorable scenario (22-i) includes the following:

- Fully developed, low-input, methanol-from-biomass system, where biofuels are used instead of diesel fuel in trucks and tractors (Scenario 22-b);

- No fertilizer used at all (Scenario 22-c);

- High-yield SRIC (Scenario 22-d);

- Very efficient methanol vehicles (Scenario 9-a); and

- Minimal energy embodied in capital equipment and relatively low emissions of non- $\mathrm{CO}_{2}$ greenhouse gases from conversion facilities (Scenarios 22-a and j; note that the estimates of emissions from biomass-to-methanol facilities in Table A.1 are very uncertain).

This reduction does not count any one-time sequestering of $\mathrm{CO}_{2}$ that would result if the SRIC plantation were to replace an ecosystem (such as cropland) that has a lower carbon content. This one-time sequestering could offset several decades of cmissions from the base-case biomethanol cycle (Scenario 22-e; see App. K).

On the other hand, the advantage of methanol from biomass diminishes markedly if all the following conditions hold:

- Fertilizer is used heavily (Scenario 22-g),

- The fertilizer produces a large amount of $\mathrm{N}_{2} \mathrm{O}\left(\mathrm{N}_{2} \mathrm{O}\right.$ emissions from fertilized SRIC systems are not well known) (Scenario 22-h),

- Available estimates of the amount of energy embodied in the materials used throughout the biofuel cycle are accurate (Scenario 22-f), and

- Methanol vehicles have only a modest efficiency advantage over gasoline vehicles (Scenario 18-h). 
In fact, in the worst case, which combines all the scenarios above, and with a 20-year time horizon, biomethanc 1 provides almost no benefit when compared with the gasoline baseline (Scenario 22-j). Therefore, although biofuels provide the potential for large reductions in emissions of greenhouse gases, the reduction is not automatic. Analyses of the greenhouse impacts of biofuel programs must pay close attention to such elements as the amount of fertilizer used and the amount of energy embodied in materials.

\subsection{SCENARIOS 23 AND 24}

These scenarios compare emissions from CNG and LNG vehicles. The results depend on assumptions associated with the following factors:

- Thermal efficiency of the NG engine relative to the gasoline engine (Scenarios 9-b, 23-i, and 24-a and b);

- Magnitude of tailpipe $\mathrm{CH}_{4}$ emissions -- the current database (see App. M) shows a wide range of emissions (Scenarios 23-a and 24- $d$ and e);

- Time horizon, which determines the importance of the $\mathrm{CH}_{4}$ emissions;

- Amount and kind of energy use to compress or liquefy gas -.. a compressor located on a high-pressure transmission line has much less work to do, and so consumes less electricity and produces less greenhouse gas (Scenarios 23-b, d, e, and o);

- Range of the vehicle, which determines the size and weight of the storage tanks, which in turn affects the efficiency of the vehicle (Scenarios 2.3-g and q);

- Lifetime of the vehicle and the storage tanks -- a longer life results in lower lifetime-average emissions from materials manufacture and vehicle assembly (Scenario 23-c);

- Amount of energy used to recover and process NG (Scenarios 2.3-h, $p$, and s);

- Rate of leakage from the gas-distribution network (Scenarios 23-u and 24-c);

- Amount of CO emissions from the tailpipe (Scenario 23-m); and

- Other factors. 
Most of these factors have roughly the same degree of importance, except the amount and kind of energy used to compress gas is more important, and the amount of energy used to recover and process gas is somewhat less important than most of the other factors. Thus, although previous analyses focused on tailpipe $\mathrm{CH}_{4}$ emissions, this analysis shows that there are many other unknown variables that are at least as important.

In the best case, the use of CNG or LNG reduces greenhouse gas emissions by more than 25\% when compared with the gasoline baseline and by nearly $10 \%$ when compared with the diesel-fuel baseline (Scenarios 23-v and 24-h). For this result to be realized, however, $\mathrm{NG}$ vehicles must be able to use lean-burn technology and still meet a $\mathrm{NO}_{x}$ standard, and compression or liquefaction stations must be located over high-pressure pipelines and use gas as a fuel. In more realistic "best-case" scenarios, NG velhicles provide a $15-20 \%$ reduction in greenhouse gas cmissions.

In the worst case, emissions from NG vehicles can be up to $30 \%$ or $40 \%$ higher than emissions from gasoline or diesel vehicles (Scenarios 23. $w$ and $x$ and 24-i). This result occurs if $N G$ LDVs have such a difficult time meeting the $\mathrm{NO}_{x}$ standard that they operate slightly rich and forego a higher compression ratio, which reduces efficiency and increases $\mathrm{CO}$ emissions (Scenario 23-n); and it they have a 350-mi insterad of a 250-mi driving range, which increases the weight of the tanks and decreases the efficiency of the vehicles (Scenario 23-q); and if gas leaks from the grid are $2 \%$ instead of $0.3 \%$ (Scenario 23-u). However, the first and the last of these conditions are unlikely, and a more realistic estimate of the worst-case scenario for dedicated NG vehicles would be "no change" with respect to gasoline and diesel fuel.

If CNG is made from LNG that was made from remote $N G$, total fuel-cycle, $\mathrm{CO}_{2}$-equivalent emissions are greater than in the gasoline base case (Scenario 23-r). The use of remote rather than domestic gas results in a substantial amount of extra cmissions from several sources: pipeline transport to the liquefaction plant, lifulefaction, transport in ING tankers, and regasification. However, it makes much more sense to use LNG from remote gas as $L N G$ in or near the receiving port city. In fact, the use of ING from remote gas results in about the same emissions as the use of ING made on site from domestic pipeline gas, because in the remote-gas case, the greater emissions from LNG transport are offset by the lower emissions from liquefaction (Scenario 23-t). (Recall that the domestic-LNG base-case here assumes that I.NG is liquefied at the service station by small liquefiers; these liquefiers are less efficient than the large liquefiers used in remote-LNG projects.) Hence, if remole gas is to be used as a transportation fuel, it is best, from a greenhouse standpoint, to use it as I.NG rather than CNG or methanol. (This comparison may not be completely fair, since it assumes that LNG would be used in the port city but CNG and methanol would be used inland. However, limiting the use of CNG and methanol to port cities does not significantly alter the results.) C.NG or LNG, like methanol, can be made from gas that would otherwise be flared, which allows for large reductions in emissions of greenhouse gases (Scenarios 23-j and k). 


\subsection{SCENARIOS 25 AND 26}

These scenarios test the effect of different assumptions about the following conditions:

- Source of LPG -- either NGL plants or refineries (Scenarios 25-a and $b$ and $26-a$ and $b$ ),

- Efficiency of and emissions from LPG vehicles (Scenarios 9-f, 25-e and $f$, and 26-e through $h$ ), and

- Composition of L.PG (Scenarios 25-c and $\mathrm{d}$ and 26-c and d).

Of these, the relative thermal efficiency of the LPG vehicle is most important factor, and the butane/propane composition of LPG is the least. Because relatively few variables were considered in these LPG scenario analyses, the difference between the best and the worst case is less for L.PG vehicles than for the other alternative-fuel vehicles.

This analysis indicates that the use of LPG will reduce emissions of greenhouse gases from LDVs by $15-30 \%$ and will reduce emissions from HDVs by a slight amount (Scenarios 25-g and $h$ and $26-i$ and $j$ ). The LPG fuel cycle thus consistently emits the least amount of greenhouse gases of any ICEV cycle that uses fossil fuel. There are two caveats to this conclusion, however. First, it does not necessarily apply to high levels of LPG production. Second, if the refinery energy cost of making LPG is much higher than estimated here (see App. H) and if all the LPG is made at the refinery, LPG looks less attractive (Scenarios 25-i and 26-k).

\subsection{SCENARIO 27}

There is no simple overall assessment of the greenhouse effect of ethanol from corn. Although the ethanol "base case" considered here shows a large increase in the amount of greenhouse gas emissions when compared with the gasoline and diese! baselines, there are many scenarios in which the increase is much less, and there are even some in which ethanol from corn actually results in a decrease. In the best case, in which corn stover is used as the process fuel, ethanol from corn can reduce greenhouse gas emissions by more than 60\% (Scenarios 27-t and v). In the worst case, in which coal is used as the process fuel, emissions are more than $50 \%$ higher than they are in the petroleum-fuel cases (Scenario 27-w). The extraordinarily wide range of results is caused by the (1) variety of energy sources that can be used to provide process heat, (2) difficulty involved in allocating emissions among the multiple products of the process, (3) uncertainty involved in estimating emissions resulting from fertilizer use, and (4) uncertainty involved in estimating the energy efficiency of ethanol vehicles and ethanol production plants. 
It is perhaps most important to distinguish the results by type of process fuel. (oal, NG, and corn-crop residue can all provide heat for the ethanol-production process. The combustion of com-crop resldues does not produce net $\mathrm{CO}_{2}$, because the corn residue is either burnt or left to rot. (The removal of the residue from the field for use as a fuel does increase nulrient requirements, and this factor has been accounted for here.) Simply using corn residue instead of coal as a fuel swings the results for ethanol from moderately unfavorable to moderately favorable, all other factors being equal (Scenario 27-j). Using NG instead of coal results in about half the emissions reduction that the use of corn stover does (Scenario 27-i).

Many other variables are quite important. Using very efficient corn-toethanol conversion technologies can substantially reduce emissions from the basecase level (Scenario 27-g). Because much of the heat required in an ethanol plant is for drying the wet by-products of the distillation process, not drying these byproducts can greatly reduce energy requirements and hence greenhouse gas emissions (Scenario 27-k). (This scenario is practical only when the wet slop can be used as a feed at the site of ethanol production.) Reducing the use of fertilizer reduces emissions from fertilizer manafacture and from denitrification and nitrification of nitrogenous fertilizers $10 \mathrm{~N}_{2} \mathrm{O}$ and $\mathrm{NO}_{x}$. fior example, "low-inpul" agriculture, in which fertilizer use is only $310 \%$ of the base-case level, greatly reduces total fuel-cycle, greenhouse-gas emissions; in fact, emission levels are below the level of those from the gasoline base-case vehicle (Scenario 27-b). Even at the basecase level of fertilizer use, the uncertainty in the level of $\mathrm{N}_{2} \mathrm{O}$ emissions alone has a considerable effect on the results (Scenario 27-a). $\mathrm{N}_{2} \mathrm{O}$ emissions from corn fields need to be better documented. As with all the alternative-fuel cycles, the efficiency of the alternative-fuel vehicle relative to the gasoline or diesel vehicle is quite important. In the case of LDV s, the potential relative efficiency gain may be constrained by the tight $\mathrm{NO}_{x}$ standards of the new Clean Air Act Amendments $(\wedge$ pp. B).

The corn-to-ethanol process results in products other than ethanol; ronsequently, greenhouse gas emissions per unit of ethanol depend on how one allocates the lotal emissions of the corn-conversion process among the products. The difficulty of allocaling emissions is discussed in App. K. Results show that allocation is very important. In the hase case, emissions from the manufacture of the products replaced by the by-products of the corn-to-ethanol process (e.g., soybeans replaced by distillers' dried grains and solubles, or DDGS) are deducted from total (missions from corn farming and conversion. The remaining emissions are assigned (o) ethanol. However, if emissions are allocated to all products (ethanol, DDGS, corn oil, clc.) on the basis of their value or energy content, then the corn-to-ethanol cycle produces less $\mathrm{CO}_{2}$-equivalent emissions than does the gasoline cycle (Scenario 27-f). Uncertainty in assigning by-product credits has as much of an effect on emissions as does switching from coal to corn stover.

Yet another imporlant and uncertain variable in the corn-to-ethanol cycle is the anount of emissions from the manufacture and assembly of materials used to 
make farm equipment and the corn-l(t)-ethanol plant itself. It appears that a large amount of energy is embodied in the materials used to make ethanol production facilities and farm equipment (Table K.7) -- much more than is embodied in the facilities and equipment used in the gasoline cycle, on a Btu of embodied energy/Btu of product basis. If emissions from the manufacture and assembly of these materials are counted, fuel-cycle emissions increase considerably (Scenario 27-m). These sources, too, need to be better documented.

Finally, if the corn grown to produce ethanol were to replace rangeland, $\mathrm{CO}_{2}$ would be emitted from the soll, because frequently disturbed agricultural solls contain less carbon than rangeland soils (Table K.12). This emission can actually be equivalent to several years of total $\mathrm{CO}_{2}$-equivalent emissions from the entire ethanol-to-corn cycle (Scenario 27-0).

The general message of these corn-to-ethanol scenarios is that one can pick values for a set of assumptions that will support virtually any conclusion about the impact of the corn-to-cthanol cycle on global warming.

\subsection{SCENARIO 28}

Generally, the discussion for Scenario 22 (methanol from wood) applies to this scenario, which tests ethanol from wood. The most important difference is that the ethanol process produces excess electricity for sale. This situation results in a substantial emissions credit, which makes overall emissions from the wood-toethanol cycle lower than thuse from the wood-to-methanol cycle. For example, the best case for ethanol from wood (Scenario 28-1) is much better than the best case for methanol from wood (Scenario 22-i); in fact, it provides the largest percentage reduction in total fuel-cycle emissions of any alternative examined here (beciuse? of the large electricity-generation credit). Nevertheless, the variables important in the methanol case -- intensity of fertilizer use, use of biofuels in trucks and tractors, vehicle efficiency, and yield per acre -- are important in the ethanol case, and for the same reasons. As in the methanol case, the values for these variables can be chosen to produce relatively unfavorable results (Scenario $28-\mathrm{m}$ ).

The result for ethanol from wood spans a huge range, from the virtual elimination of all greenhouse gases to no change relative to the gasoline base casce. This range illustrates, once again, the dramatic effects that can result if assumptions about emissions of non- $\mathrm{CO}_{2}$ greenhouse gases, the time horizon, and the cumulative force of many independent assumptions are all either favorable or unfavorable.

\subsection{SCENARIO 29}

The effect of IiVs can range from a moderate increase to nearly complete elimination of greenhouse gas emissions, depending on assumplions about the 
$\mathrm{mi} / \mathrm{kWh}$ effictency of the vehicle, the effictency of electrictly generation, the amisstons from electricty generation, and the kind of fuel used to generale electricity.

The most important factor is the kind of fuel that is used to genorate the electricity used to recharge the $\mathrm{EV}$ s. The use of coal-based power can cause a slight increase to a large decrease in $\mathrm{CO}_{2}$-equivalent emisstons (when compared with the gasoline baseline), depending primarily on the effictency of the power plants and the vehicles (Scenarios 29-p, q, and $r$ ). The use of NG-based power allows for a moderate to very large reduction In fuel-cycle emissions (Scenarios 29-u, v, and $w$ ), because of NG's lower carbon/Btu content. In fact, highly efficient battery-powered LV V s, using electricity generated by highly efficient combined-cycle or intercooled stoim-injected gas turbines (Willams and Larson, 1989) or by NG fuel cells, offer the largest reduction of any fossil-fuel-based option eximined in this analysis (Sconarios 29-v and $w$ ). The use of solar or nuclear power virtually eliminates all lucl-cycle greenhouse gas emissions other than those assoctated with vehicle manulacture (Scenarios 29-m, n, and o). Nole the effictency of urantum mining and cririchment has no appredable effect on the results, mainly because the amount of upstram emissions from the nuclear power cycle is not very large in the base case.

The use of biomass-derived electricily could have a wide range of effects, drpending on the amount of acreage fertilized and the amount of fertilizer used, the amount of $\mathrm{N}_{2} \mathrm{O}$ evolved from fertilizel, the amount of energy embodied in 'fuipment and facilities, the efficiency of power generation, the efficiency of vehicles, land use effects, and other factors. In the best case, if trees permanently replaced crops or grasses, the one-time increase in the standing stock of carbon $\left(\mathrm{CO}_{2}\right)$ would offsel decides of fucl-cycle emissions. In the worst case, under the short-term horizon, fuel-cycle $\mathrm{CO}_{2}$ emissions would actually be the same as those from a gasoline vehicle, in large part because of the extremely high lovel of amissions of non- $\mathrm{CO}_{2}$ greenhouse gases from feedstock production.

limissions from the use of liVs depend on the actual mix of fuels used to generinte the electricity that would not have been generated had there been no liV progrim. This mix depends on the cost and avallability of fuels, environmental regulations, reliability of power plank, and other factors, all of which are difficult to project. To give an idea of how this mix, and thus emissions from power plants, can vary, I show the emission results for the average power mixes used in five major U.S. cilie: (Scenarios 29-h through 1). ("The "average" power mix in a cily or region is based on total electricity generation, for all end uses, in a year.) The actual marginal or specific mix used by liVs, however, will almost certainly not be the same as the avernge or all-purpose mix in these cilies. In all live cities, liVs offer a moderate to lange reduction in greenhouse gas anissions, primarily becousce of the rolatively lisphe nese of onal in this scomarios.

When a fossil fuel is used to generate electricity, overall emissions are

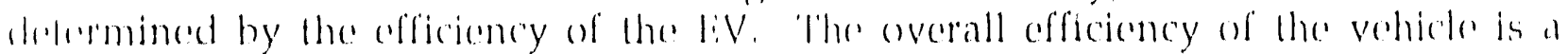


function of the weight of the vehicle and the effictency of the battery', rechitigere, and drlvetrain. The weight of the vehicle is a function of drivelrain and battery lechnology and vehicle range, and the offictency of the components is a function of technology and how the vehicle is used. For example, the use of $\mathrm{Pb} / \mathrm{acid}$ rather than $\mathrm{Na} / \mathrm{S}$ batteries greatly increases emissions of greenhouse gases (Scenario 29-d), because $\mathrm{Pb} /$ acd batterles are much heavier and are recharged much less efficiontly. In fact, the difference in recharging efficiency $(75 \%$ versus $92 \%)$ is the main cause of the increase, because fuel-cycle emissions are proportional to the efficioncy of recharging. Conversely, lightwelght, aerodynamic EVs (like the GM Impact) with very efficient powertrains and efficient batteries significantly reduce emissions of greenhouse gases (Scenario 29-a).

Greenhouse gas emissions from the EV cycle are related to how the vehicle is used. In the base case, I assume that LVs are used only in city driving. If EVs are used in highway driving as well, their efficiency advantage relative to gasoline vehicles declines, because gasoline vohicles are more efficient in highway driving than in city drlving, whereas EVs are not (see App. B). This large drop in elficiency substantially increases greenhouse gas emissions (Scenario 29-c). Also, if liVs are consistently recharged after only shallow discharges, the efficiency of the battery can be substantially degraded, which causes a large increase in greenhouse gas emissions (Scenario 29-e).

Emissions from the use of EVs are an indirect function of the range of the vehicle. The longer the range is, the heavier the battery is and the lower the overall efficiency is. Increasing or decreasing the range by 50 miles results in a change of almost 10 percentage points in emissions from the $\mathrm{EV}$ relative to the gasoline vohicle (Scenarios $29-y$ and $z$ ).

In the base case, the amourit of $\mathrm{N}_{2} \mathrm{O}$ formed by the corona discharge from high-voltage power lines is too small to significantly affect the results. However, if the high-end estimate of $\mathrm{N}_{2} \mathrm{O}$ from this source is accurate (App. N), electricity transmission becomes a nontrivial source of greenhouse gas emissions (Scenario 29-aa). This source of $\mathrm{N}_{2} \mathrm{O}$ needs to be investigated further.

fior most of the variables examined here, a change in value changes the amount of overall greenhouse gas enissions proportionately. Thus, combinations of changes in these variables, all in the same direction (i.e., favorable or unfavorable), can have an enormous effect on the overall result. For example, if liVs were to use $\mathrm{Pb} /$ acid technology, be used in combined city/highway driving, and be recharged after shallow discharges (an unlikely combination, to be sure), they would cause a huge increase in greenhouse gas emissions, given the base-case marginal power mix (Scenario 29-g). On the other hand, the use of the best E:V lechnology', logether with a long EV life (Sconario 29-b), would greally reduce greenhouse gas emissions (Scenario 29-f). The gap between these best and worst cases is more than 10) percentage points. 
In conclusion, the overall standing of EVs hinges on two classes of variables that are very hard to project: the marginal $\mathrm{mix}$ of power used to recharge vehicles and the technology and use characteristics of the vehicles (including their range). These factors must be considered in any analysis of the greenhouse impact of EV policies.

\subsection{SCENARIO 30}

This hydrogen-in-ICEVs scenario illustrates the importance of considering cmissions from the entire nuclear fuel cycle as opposed to just those emissions from the tailpipe. Hydrogen vehicles themselves produce virtually no greenhouse gases, and hydrogen transport is virtually free of emissions, but the production and compression or liquefaction of hydrogen consumes a large amount of electricity. In fact, coal-fired power plants providing power to hydrogen liquefiers will by themselves emit about as much greenhousc gas as does the entire gasoline production-and-use cycle (Scenario 30-e).

Very efficient enrichment technologies, such as laser-isotope separation, use much less electricity than does gaseous diffusion and noticeably reduce total lifecycle, $\mathrm{CO}_{2}$-equivalent emissions from nuclear-electrolytic-hydrogen vehicles (Scenarios 30-c and g). More dramatic results would occur if nuclear power (rather than the U.S. year-2000 mix, dominated by coal) were used to liquefy hydrogen; emissions of greenhouse gases would decline substantially (Scenario 30-f). Combining all-nuclear liquefaction with advanced enrichment technology virtually climinates greenhouse gas emissions -- any emissions that would remain would be a result of the manufacture and assembly of materials for the vehicle. At this point, nuclear-electrolytic hydrogen would fulfill its promise.

The analysis for solar-electrolytic hydrogen would be similar, except that in all cases, the use of solar power produces less greenhouse gas than does the use of nuclear power.

\subsection{SCENARIO 31}

This fuel-cell scenario examines the results of using more efficient processes to produce the methanol used in fuel-cell vehicles. The use of more efficient gasconversion technology, or OTM/LPM/IGCC coproduction of methanol and electricity from coal, further reduces emissions of greenhouse gases by 10 to 20 absolute percentage points.

Although fuel-cell vehicles using methanol made from NG offer a substantial reduction in emissions of greenhouse gases when compared with current gasoline 1.1) V s, this reduction is much less than that provided by hydrogen- or biomethanolpowered fuel-cell vehicles. Moreover, any increase in vehicle miles traveled will, in 
the long run, reduce the large per-mile reduction in emissions available with NGderived methanol, so that even $\mathrm{NG} /$ methanol-powered fuel cell vehicles will not be a long-run solution to the greenhouse problem. Furthermore, by the time fuel-cell vehicles would be common, methanol would probably be made, in part, from coal, and fuel-cell vehicles using methanol from coal offer little or no greenhouse benefit at all. Consequently, vehicles using methanol fuel cells would offer substantial long-term reductions in emissions of greenhouse gases only if biomass were used as the feedstock.

Biomass could be made into hydrogen as well as into methanol (DeLuchi, Larson, and Williams, 1991). However, the biomass-to-hydrogen fuel cycle could produce more emissicrs thait the biomass-to-methanol fuel cycle, because of the potential for substantial $\mathrm{CO}_{2}$-equivalent emissions to result from the use of fossil electricity to compress or liquefy hydrogen. These emissions might erase the efficiency and emissions advantage of the biomass-to-hydrogen fuel cycle. However, if solar or biomass power were used to compress or liquefy hydrogen, the hydrogen cycle would probably be superior to the methanol cycle. 


\section{CONCLUSIONS}

\subsection{TRANSPORTATION SECTOR CONCLUSIONS}

\subsubsection{Coal}

In most cases, $\mathrm{CO}_{2}$-equivalent emissions from the transportation sector increase when coal is used (1) to produce methanol, hydrogen, or SNG for ICEVs (see DeLuchi et al., Transportation Fuels and the Greenhouse Effect, 1987, for analyses of hydrogen and SNG from coal); (2) to produce electricity for battery-powered EVs; or (3) as a process fuel in the corn-to-ethanol fuel cycle. Even when the most efficient way of producing methanol from coal is used (OTM/LPM/IGCC; see App. J), the result is still a considerable increase in emissions of greenhouse gases over those that result from the current gasoline production and use cycle. The use of coal as a process fuel in the ethanol-from-corn cycle also contributes substantially to total fuel-cycle emissions.

The only way (other than $\mathrm{CO}_{2}$ disposal in, for example, depleted $\mathrm{NG}$ reservoirs) to use coal as a primary energy source in the transportation sector without causing an increase in greenhouse gas emissions is to greatly increase the overall energy efficiency of the entire transportation fuel cycle. This goal can be accomplished by using coal-derived methanol in fuel-cell vehicles (which are roughly twice as efficient as ICEVs) or by using coal in very efficient, low-polluting power plants, such as fuel cells, to produce electricity for very efficient batterypowered EVs. The acceptable use of coal, then, is linked to the development of advanced electric and fuel-cell vehicles. Even in these cases, coal provides an actual reduction in greenhouse gas emissions only in the very best case for coal-based power plants and EVs. (Coal use with $\mathrm{CO}_{2}$ disposal also reduces $\mathrm{CO}_{2}$ ernissions, but $\mathrm{CO}_{2}$ that is disposed of is not the same as $\mathrm{CO}_{2}$ that was not generated in the first place.)

\subsubsection{Natural Gas}

Slight to moderate reductions in $\mathrm{CO}_{2}$-equivalent emissions result from (1) using NG to produce methanol, CNG, or LNG for alternative-fuel vehicles or electricity for EVs; (2) using NG as a process fuel in the corn-to-ethanol cycle; or (3) using NG liquids to make LPG. The reductions are, in most cases, less than $25 \%$ of current per-mile emissions from the use of gasoline and diesel fuel. In the long run, such moderate reductions would do little more than help keep the emissions level steady for a few years as venicle miles traveled increase. In many cases, then, VG could act as a transitional fuel or feedstock in a strategy designed to control enissions of greenhouse gases, but it cannot be viewed as a long-run solution. The main exception to this general conclusion would be to use NG; in very efficient, low- 
polluting advanced gas turbines or fuel cells that provide power for very oflicient EVs. In the best case, this use of $N G$ would greatly reduce per-mile emissions of greenhouse gases from motor vehicles.

\subsubsection{Improved Fuel Economy}

Improving fleet-average fuel economy does reduce total fuel-cycle emissions of greenhouse gases from motor vehicles. However, emissions of greenhouse gases from motor vehicles are not linearly related to fuel economy, primarily because tailpipe emissions of non- $\mathrm{CO}_{2}$ greenhouse gases are not related to fuel economy. In other words, a doubling of fuel economy reduces fuel-cycle emissions of greenhouse gases by less than a factor of two. The reason that tailpipe emissions of greenhouse gases are not related to fuel economy is because the emission standards for vehicles are specified in terms of grams per mile of travel, not grams per gallon or Btu of fuel. By contrast, emission standards for power plants are in grams per Btu of fuel input. Thus, improving fuel efficiency is a more effective greenhouse gas control strategy for power plants than for motor vehicles.

\subsubsection{Woody Biomass}

The production of alcohol fuels, SNG, or electricity from woody biomass can greatly reduce emissions of greenhouse gases. In the best cases, the use of woodbased fuels can virtually eliminate these emissions. In fact, if wood plantations are established on marginal cropland, the initial buildup of carbon (from atmospheric $\mathrm{CO}_{2}$ ) in the biomass will offset decades of $\mathrm{CO}_{2}$-equivalent emissions from the production and use of biofuels, including emissions from the manufacture of materials for conversion plants, farm equipment, and motor vehicles (see App. K). Thus, with the right land-use policy, an energy-efficient, biofuels-from-wood program that uses little or no fertilizer will result in zero net emissions of greenhouse gases for decades. This potential to mitigate transportation's contribution to the greenhouse problem is a major attraction of biofuels made from wood.

On the other hand, if wood plantations require a lot of fertilizer, and if the manufacture of materials and equipment results in substantial emissions of greenhouse gases (and if other unfavorable conditions hold), then the biofuel cycles will provide no more than modest reduclions -- and perhaps even no reduction at all -- in greenhouse gas emissions.

Overall, the wide range of possible outcomes for biofuels show that analysts must pay serious attention to (1) emissions from the use of "embodied" energy (e.g., energy used to make fertilizer, buildings, and equipment), (2) emissions of non- $\mathrm{CO}_{2}$ greenhouse gases that result from combustion (e.g., $N O_{x}$ from the tailpipe), (3) emissions of greenhouse gases that do not result from combustion (e.g., $\mathrm{N}_{2} \mathrm{O}$ from 
nitrification of fertilizer), and (4) changes in land use. An analysis that focuses only on emissions of $\mathrm{CO}_{2}$ that result from combustion can miss all these other sources and seriously misrepresent the greenhouse impact of the biofuel cycle.

\subsubsection{Solar and Nuclear Energy}

The use of solar energy to make electricity for battery-powered $E V^{\prime} s$ or hydrogen for fuel cell vehicles nearly eliminates emissions of greenhouse gases, as long as thie solar energy is used throughout most of the fuel cycle. Solar energy is the most attractive supply-side option for reducing emissions of greenhouse gases.

The use of nuclear power to make electricity or hydrogen also greatly decreases emissions of greenhouse gases, but not as much as solar power (given current gaseous-diffusion uranium-enrichment technology). The use of more efficient uranium-enrichment technologies, such as the gas centrifuge or the laser isolope separation technique, would make greenhouse gas emissions from the nuclear fuel cycle comparable with those from the solar fuel cycle.

The stipulation that nonfossil energy be used throughout the fuel cycle and not just to make the primary energy carrier has an important relationship to total emissions. In fact, as shown in the hydrogen scenario analyses (Table 12), emissions from the use of energy for some upstream processes, such as hydrogen liquefaction, can be nearly as large as total emissions from the gasoline fuel cycle.

\subsubsection{Non- $\mathrm{CO}_{2}$ Greenhouse Gases}

This analysis shows that non- $\mathrm{CO}_{2}$ greenhouse gases $-\mathrm{CH}_{4}, \mathrm{~N}_{2} \mathrm{O}, \mathrm{NO}_{x}, \mathrm{CO}$, and NMOCs -- play a surprisingly important role in total greenhouse gas emissions. These gases dominate the ethanol-from-wood cycle and are a major part of the other biofuel cycles. They constitute a large part of total $\mathrm{CO}_{2}$-equivalent emissions from fossil-fuel-based cycles -- more than 30\%, in the case of CNG. The contribution of non- $\mathrm{CO}_{2}$ greenhouse gases also determines how an alternative fuel ranks relative to petroleum fuel over different time horizons: the larger its contribution of non- $\mathrm{CO}_{2}$ greenhouse gases is to total emissions, the better the alternative is in the longer run, because as time passes, the non- $\mathrm{CO}_{2}$ gases are down-weighted in their contribution to total emissions relative to $\mathrm{CO}_{2}$.

Emissions of non- $\mathrm{CO}_{2}$ greenhouse gases depend on the type of fuel, energy technology, and emission control technology used. It follows that the specific assumptions about these parameters are thus quite important. For example, because $\mathrm{NC}$-driven engines emit much more $\mathrm{CH}_{4}$ than do NG-driven turbines, assumptions whoul the fraction of pipeline compressors that are driven by engines rather than by turbines can have a nontrivial effect on $\mathrm{CO}_{2}$-equivalent emissions from $\mathrm{NG}$ fuel cycles. Another example is gasoline-fueled farm equipment, which emits huge 
amounts of $\mathrm{CO}$. Thus, the use of gasoline on a farm can also contribute a nontrivial amount of $\mathrm{CO}_{2}$-equivalent emissions. Limissions of $\mathrm{NO}_{x}$ and $\mathrm{CH}_{4}$ from $\mathrm{NG}-(\mathrm{l})$ methanol plants, coal-to-methanol plants, wood-to-fuel plants, and corn-to-(hanol plants might also be important; they need to be measured accurately to find out.

If the IPCC's estimate of the global warming potential of $\mathrm{NO}_{x}$ is accurate (Table 8), in many cases, $\mathrm{NO}_{x}$ emissions alone account for a substantial fraction of total fuel-cycle, $\mathrm{CO}_{2}$-equivalent emissions. For example, diesel HDVs in Europe are projected to emit such la:ge quantities of $\mathrm{NO}_{x}$ that in the short term (20 years), these $\mathrm{NO}_{x}$ emissions will contribute more to global warming than all the other greenhouse gases, including $\mathrm{CO}_{2}$, combined. Preliminary results such as these indicate the importance of accurately calculating the global warming potential of $n(n)-\mathrm{CO}_{2}$ greenhouse gases.

\subsubsection{Comparative Efficiency of Alternative Fuel Vehicles}

The efficiency of alternative-fuel ICEVs relative to gasoline and diesel vehicles is an important factor in total fuel-cycle emissions of greenhouse gases. For example, there is a large difference in the amount of total fuel-cycle, $\mathrm{CO}_{2}$-equivalent emissions generated when an ethanol vehicle is $28 \%$ more efficient than a comparable gasoline vehicle and when an ethanol vehicle is only $9 \%$ more efficient. However, projecting the in-use fuel efficiency of alternative-fuel vehicles is a complicated task. It requires an analysis of the interaction of the cost of efficiencyimproving technologies and the gains provided by these technologies with emission standards, rt: $:$ performance, and consumer demand for efficiency.

In the alternative-fuel community, most of the debate about fuel efficincy has focused on the technical potential for efficiency gains. Unfortunately, there has been little discussion of some equally important issues. For example, how will tailpipe emission standards constrain potential efficiency gains? How will consumers respond to the greater cost of improved efficiency, which will result in higher vehicle prices or reduced performance? Is it reasonable to expect that manufacturers will offer and that consumers will buy all the cost-effective, efficiency-maximizing technologies and designs available?

As discussed in App. B, tighter emission standards may preclude the use of some efficiency-improving technologies. For example, the use of lean-burn technology, which greatly improves the thermal efficiency of an engine, renders a $\mathrm{NO}_{x}$ reduction catalyst almost useless. Therefore, lean-burn vehicles will probably not be able to meet the $0.4 \mathrm{~g} / \mathrm{mi} \mathrm{NO}$ standard to be phased in under the new Clean Air Act Amendments. Without this lean-burn option, alternative-fuel vehicles will probably not be more than $20 \%$ more efficient than gasoline vehicles.

Furthermore, some of the technologies used to improve the efficiency of alternative-fuel vehicles could be applied, to some degree, to gasoline vehicles. For 
example, Toyota Motor Corp. (1989, p. 49) believes that lean-burn gasoline technology "will be very important in the near future." If both lean-burn gasoline vehicles and alternative-fuel vehicles will be able to meet the $0.4 \mathrm{~g} / \mathrm{mi} \mathrm{NO}_{\mathrm{x}}$ standard, the alternative-fuel vehicles will have less of an efficiency advantage over the gasoline vehicles. Nevertheless, research to date suggests that it will be quite difficult for lean-burn gasoline vehicles to achieve the $0.4 \mathrm{~g} / \mathrm{mi} \mathrm{NO}$ in-use standard (Held et al., 1990; Diwell et al., 1988); certainly, it will be more difficult for them than for most alternative-fuel vehicles.

It may also be possible to increase the compression ratio of gasoline vehicles by making commercial gasoline more knock resistant. However, it is not likely that the compression ratio can be increased to anywhere near the level achievable with alternative fuels.

Even if emission standards do not constrain efficiency improvements, vehicles may still not be as efficient as technically possible, because consumers may not demand the highest efficiency attainable. In the first place, very high levels of efficiency may not be cost effective according to a rationil social-cost accounting standard. Even if very high levels of efficiency were cost effective, however, consumers might still not be interested. Efficiency, in the auto industry and elsewhere, has been difficult to sell. However, the efficiency situation is somewhat different for alternative-fuel vehicles than gasoline vehicles. Higher efficiency does more than just reduce fuel cost; it increases the range of the vehicle or reduces the volume of fuel storage. These benefits are less important in gasoline vehicles, which have small fuel tanks and long driving ranges to begin with. Nevertheless, the conclusion remains that to make reasonable claims about what kind of alternativefuel ICEVs will actually be sold and used, one first must analyze how consumers will trade off efficiency with cost and performance.

\subsubsection{Comparative Efficiency of Electric Vehicles}

The in-use efficiency of EVs relative to gasoline vehicles is an important factor in overall greenhouse gas emissions from the use of EVs. The relative efficiency of EV s is especially difficult to estimate, because it is a function not only of the type of battery and powertrain technology but also of how the vehicle is driven. Electric powertrains are much more efficient than iCEV powertrains under any circumstance, but their advantage is much greater in city driving than in highway driving. Furthermore, some types of batteries become less efficient if they are repeatedly recharged after shallow discharges (DOE, Assessment of Costs and Benefits "I Flexible and Alternatioe Fuel Use in the U.S. Transportation Sector, Technical Report Four: Vohicle and Fuel Distribution Re'quir'ments, 1990). Thus, an EV that is recharged every night after relatively short highway trips will fare much worse, relative to the ICI:V it replaces, than will an EV that is recharged after a week's worth of stop-andg() driving. Compounding this uncertainty is the fact that there are so many battery and powertrain technologies available for l:Vs. Consequently, to pinpoint the 
impacts of EVs on global warming, one must project how the EVs will be used, what technologies they will use, and what fuels will be used to recharge them.

\subsubsection{Upstream Energy Use}

The amount and type of energy used by upstream processes are important factors in determining total emissions from most transportation fuel cycles. The use of energy by upstream processes, like the use of fuel by vehicles, is governed by political and economic forces. For example, the amount and kind of energy used to make a barrel of gasoline depends on the amount of gasoline being made from a barrel of crude, composition of the crude, desired composition of the gasoline, particular refining technologies used, emission standards for refineries, and other factors. The composition of gasoline, in turn, is determined by both consumer demand and environmental and safety regulations.

Similarly, the amount and type of energy used by power plants to produce electricity is a very important factor in determining $\mathrm{CO}_{2}$-equivalent emissions from the use of EVs. A mix that relies heavily on old coal-fired plants gives radically different results than a mix relying on NG fuel cells. To project which power plants will be used to provide the marginal power demanded by EVs, one must consider surh factors as the age, reliability, fuel costs, emissions, maintenance costs, capacity factors, and location of available power plants.

\subsubsection{Summary}

This analysis shows that the use of any fossil fuel feedstock to make any transportation fuel will not significantly reduce emissions of greenhouse gases as long as the transportation fuel is used in an ICEV. However, the use of $N G$ as the ultimate energy source for battery-powered or fuel-cell-powered electric-motordriven vehicles can greatly reduce emissions of greenhouse gases. Still larger reductions can be achieved by the use of nonfossil fuels (biofuels and hydrogen) in ICEVs. The biggest reductions in emissions of greenhouse gases can be achieved by the use of nonfossil fuels with electric-motor-driven vehicles. In summary, the ranking from best to worst is as follows:

1. Nonfossil fuels with electric-motor-driven vehicles,

2. Nonfossil fucls with ICEVs,

3. Fossil fuels with electric-motor-driven vehicles, and

4. Fossil fuel with ICEVs. 
Even though in the near term, the use of alternative fuels does not greatly reduce emissions of greenhouse gases, it can be a first step in a path that leads to ultra-low emissions. The key is to switch from fossil fuel feedstocks like NG to nonfossil feedstocks such as biomass and solar energy and to switch from ICEVs to electric-motor-driven vehicles. Many paths are possible; some of these follow:

- From NG-derived methanol in ICEVs to wood-derived methanol in ICEVs, then to wood-derived methanol in fuel-cell vehicles;

- From corn-derived ethanol using coal as a process fuel to cornderived ethanol using corn stover as a process fuel, then to woodderived ethanol;

- From NG to solar-electrolytic hydrogen in ICEVs (this path could begin with the addition of hydrogen $\mathrm{o}(\mathrm{NG})$;

- From battery-powered EVs using coal-based power to batterypowered EVs using biomass and solar power; or

- From a mix of CNG vehicles and battery-powered EVs to compressed-hydrogen fuel-cell vehicles, which use a fuel cell to link CNG-like fuel storage and refueling technology with an electric powertrain.

The extent and timing of these transitions will depend on many economic and regulatory factors. In general, switches will occur when nonfossil feedstocks and clectric motors become economically competitive or are mandated, directly or indirectly. An example of an indirect mandate would be a zero-emissions tailpipe standard.

\subsection{OVERALL CONCLUSIONS FOR TRANSPORTATION AND ELECTRICITY}

This analysis has three main messages. First, for most energy options, emissions of $\mathrm{CO}_{2}$ from fuel combustion account for the bulk of total greenhouse gas emissions. It thus is very important to estimate as accurately as possible the two main determinants of combustion emissions of $\mathrm{CO}_{2}$ : the carbon content of fuels (in grams per Btu) and the efficiency of fuel use (in Btu per mile or Btu per kilowatt).

The second conclusion is that $\mathrm{CO}_{2}$ is not the only greenhouse gas of interest and combustion is not the only source of greenhouse gases. Emissions of $\mathrm{CH}_{4}, \mathrm{CO}$, $\mathrm{N}_{2} \mathrm{O}, \mathrm{NO}_{x}$, and NMOCs, from both combustion and noncombustion sources, can be responsible for a large part of the tolal global warming potential of energy use. In some cases, non- $\mathrm{CO}_{2}$ greenhouse gases are collectively more important than $\mathrm{CO}_{2}$, and there are even cases in which an individual non- $\mathrm{CO}_{2}$ gas is more important than 
$\mathrm{CO}_{2}$. Analyses of energy options and the greenhouse effect must examine all greenhouse gases and all sources of emissions.

The third and most interesting point from an analytical standpoint is that the details matter a lot. The overall $\mathrm{g} / \mathrm{mi}$ or $\mathrm{g} / \mathrm{kWh}$ results are determined by hundreds of specific assumptions about such factors as the chemical composition of fucls, the stringency of emission standards, the types of emission control technologies used, how vehicles are used, where primary feedstocks come from, where fuels are produced and used, what kinds of engines or motors and fuels are used by fuelprocessing equipment, and how much fertilizer is used to grow biomass. For most energy options, assumptions about these factors can be chosen to produce results with a wide range -- from very favorable to unfavorable.

In turn, virtually all of these factors depend on political, social, and economic forces: energy prices, environmental policies, the distribution and availability of land and other resources, government support for new technologies, consumer preferences, and so on. Ultimately, then, to model emissions of greenhouse gases from the use of energy, one must analyze the broader context in which energy is produced and used. Further work on greenhouse gas emissions from the use of energy should not just refine engineering estimates of energy efficiency and emission factors but should also address these larger social, political, and economic issues.

\subsection{POLICY RECOMMENDATIONS FOR TRANSPORTATION}

This analysis has shown that large, long-term reductions in $\mathrm{CO}_{2}$-equivalent emissions from the transportation sector can be accomplished best by using fucls derived from biomass or nonfossil electricity to charge battery-powered EVs or make hydrogen for ICEVs or fuel-cell-powered EVs. From a greenhouse perspective, the policy question is: "What is holding these options back, and what can be done to encourage their adoption?"

Biofuels and solar energy are expensive on a private-cost basis, and nuclear energy is expensive and politically unpopular. Battery-powered EVs do not perform well enough to be used in all highway applications; hydrogen-powered ICEVs or fuel-cell vehicles do but are relatively expensive on a private-cost basis, and fuel storage is still problematic. In summary, current petroleum fuels are relatively cheap and alternative non- $\mathrm{CO}_{2}$-producing fuels are relatively costly on a private-cost basis, and some alternative vehicular technologies have performance drawbacks. Thus, two kinds of policies are needed to address these problems.

First, fuels and technologies should be priced at their social or full economic cost and not at their private cost. Gasoline is currently the cheapest transportation fuel on a private-cost basis, but the external cost of gasoline use, which includes the effects of air pollution and greenhouse gas emissions and the cost of defending oil 
fields in the Middle East, is probably very large. On the other hand, the use of solar power or solar-derived hydrogen has only a small external cost. Thus, if the external cost of gasoline and diesel fuel use is at the high end of a plausible range, and the private cost of electric or hydrogen vehicles using solar power (with essentially no (xternal costs) is at the low end of a plausible range, the use of electric and hydrogen vehicles (where their performance is acceptable) may be more economically efficient from the standpoint of society.

Second, research and development (R\&D) should be directed at fuel and vehicle combinations with low external costs, especially those that do not produce greenhouse gases or exacerbate global tensions, since these external costs are difficult to estimate but may be large. For EVs, R\&D should be aimed at increasing the energy density and power of batteries, reducing battery cost, and reducing recharging time without sacrificing battery performance and life. For hydrogen vehicles, R\&D should focus on increasing the mass-energy density of hydrides, reducing the desorption temperature of hydrides, increasing the no-vent period for liquid hydrogen ( $\mathrm{LH}_{2}$ ) vehicles, making the handling of $\mathrm{LI}_{2}$ boil-off safe, and reducing storage costs for both hydride and $\mathrm{LH}_{2}$ vehicles. Work on hydrogenpowered fuel-cell vehicles, which combine the best attributes of hydrogen and electric vehicles, should be greatly expanded.

Today the United States provides only modest support for the development of solar technologies and EVs, and next to no support for the development of hydrogen and fuel-cell vehicles. Considering that both these technologies are very benign environmentally and quite promising technically, this lack of support is short-sighted.

Proper pricing of petroleum fuels will encourage efficiency improvements and reduce $\mathrm{CO}_{2}$-equivalent emissions and increase the efficiency with which the nation uses resources. Proper pricing combined with increased R\&D on solar energy production and electric and hydrogen vehicles will hasten the efficient adoption of sustainable, environmentally sound, non- $\mathrm{CO}_{2}$-producing transportation options. We should begin on this path loday. 


\section{REFERENCES}

Acurex Corp., Clean Coal Fucls: Alternate Fuel Strategies for Stationary and Molile: Engines, Executive Summary, P5(0)-82-(1)20, Callfornia Energy Commisston, Sacramento (1982).

C. A. Amann, "Technical Options for Energy Conservation and Controlling Environmental Impact in Highway Vehicles," paper presented at the Conference on Energy and the Environment in the 21st Century, MIT', Cambridge, Massachusells, March 26-28 (1990)).

C. A. Amann, "The Passenger Car and the Greenhouse Effect," SAE Technical Paper Series, \#902099, Society of Automotive Engineers, Warrendale, Pennsylvania (1990)).

C. A. Amann, S. P. Ho, and T. A. Renner, "Globai Warming, Fuels, and lassenger Cars," Automotive Engineering 99(2):15-18 (1991).

W. B. Ashton, D. W. Barns, and R. A. Bradley, "A Fuel Cycle Framework for Evaluating Greenhouse Gas Emission Reduction Technology," in Proceedings of the 25th Intersociety Energy Conversion Enginecring Conference, Volume 4, 414-419, American Institute of Chemical Engineers, New York (1990),

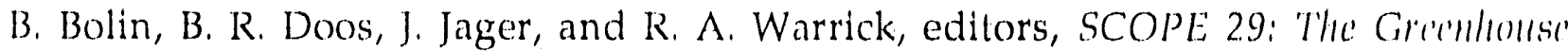
Effect, Climatic Change, and Ecosystems, John Wiley and Sons, New York (1986).

H. J. Bolle, W. Seiler, and B. Bolin, "Other Greenhouse Gases and Aerosols," in Scope 29: The Creculhouse Effect, Climatic Chunge, and Ecosystems, 157-208, edited by B. Bolin et al., John Wiley and Sons, New York (1986).

California Air Resources Board, Technical Support Division, Methodology to Calculate Emission Factors for On-Rond Motor Vehicles, Sacramento, California, November (1986).

Climate Change, the IPCC Scientific Assessiment, edited by J. T. Houghton, G. J. Jenkins, and J. J. Ephraums, Cambridge University Press, Cambridge, England (199()).

Cryogenic Fuels, Inc. (Manassas, Virginia), Letter from Roy Adkins to Palll Hathaway of Northwest Natural Gas, September 8 (1989).

Cryogenic Fuels, Inc. (Manassas, Virginia), Photocopies of slides from Roy Adkins (undated). 
M. ^. Deluchl, "limissions of Cireenhonse Gases from the Use of Gasoline, Methanol, and Other Altermatlve Transportation fuels," in Methenol as an Altermation'

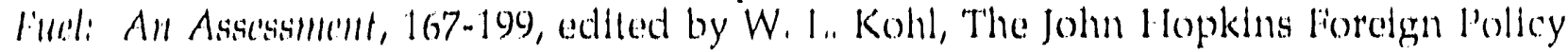
Institute (199)).

M. A. DeLuchi, "Ilydrogen Vehides: An livaluation of fiuel Storage, Performance,

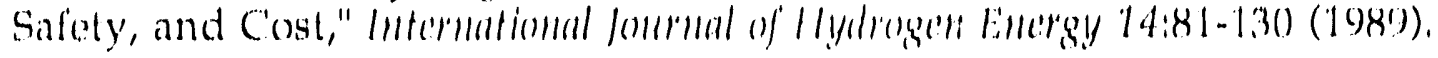

M. A. DeLuchd, R. A. Johnston, and D. Sperling, "Natural Gas Versus Methanol Vehicles: A Comparison of Resource Supply Performance, litel Storage, limisstons, Cost, Safely, and Transitions," SAE Techuical Paper Sertes, \#881656, Soctely of Automotive Engineers, Warrendale, pennsylvanta (1988).

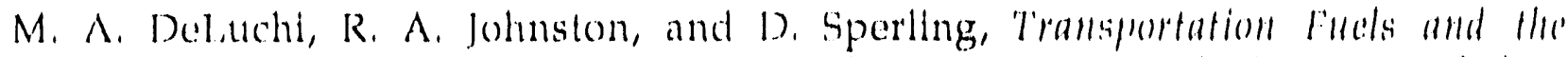

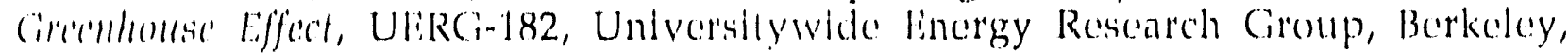
Calilornta, Docember (1987).

M. A. Beluchi, L. D. Larson, and R. H. Williams, Hydrogen and Methanol: Production

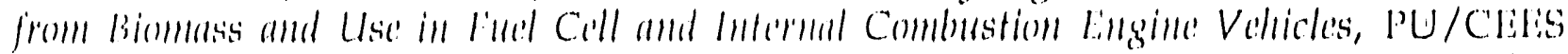
Report No, 263, Conter for Enorgy and linvirommontal Studies, l'rinceton University, New Jersey, August (190)1).

M. A. Deluchi, D. Sperling, and R. A. Johnston, A Comparation Analysis of L'uture' Transportation I'Hels, UCB-ITS-RR-87-1.3, Instilute of Transportalion Studies, University of California, Berkeley, October (1987).

M. A. Deluchi, Q. Wang, and D. Spering, "Electric Vehicles: Performance, LifeCyclo Costs, Limissions, and Recharging Rogutrements," Transportation Reserarch-A 23A:255-278 (1989),

M. Doul and A. G. Kim, Methane Control Re'se'arch: Summary of Results, 1964-1980, Bulletin 687, U. S. Department of Interior, LI. S. Bureau of Mines (1988),

A. I: Diwell, C. D. de Boer, and R. P. Green, "Engineered Control Stralegies for Improved Catalytic Control of $\mathrm{NO}_{x}$ in Lean Burn Applications," SAE Technical Paper Series, \#881595, Society of Automotive Engineers, Warrendale, Pennsylvanta (1988).

DOt: Sce U. S. Department of Energy.

liIA: See Energy Information Administration.

Liledrical World Directory of Electric Lttilitis, Electrical World, MoGraw-Hill, Now rink (1988). 


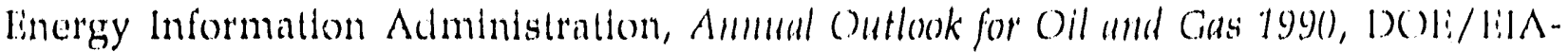
(5517(89), U. S. Department of Energy, Washington, D.C., May (199)(1)).

Energy Information Administration, Anmmal Outlook for U. S. Electric Porter 1989, Projections throngh 20(0), DOE/EIA-()474(89), U. S. Department of lincrgy, Washington, D. C., June (1989),

Energy Information Admindstration, Anmual Outlook for L. S. Electric Porn'r 1990), Projections through 2010, DCE/EIA-()474(90), U. S. Department of Encrgy, Washington, D. C., June (1990),

Energy Information Administration, Energy Consumption and Conservation Potential: Supporting Analysis for the National Encrgy Strategy, SR/NES/90-02, U. S. Department of Energy, Washington, D.C., December (1990).

Energy Information Administration, Howsehold Vehicles Energy Consumption 1988, DOE/EIA-(2464(88), U. S. Department of Energy, Washington, D. C., February (199(1).

Energy Information Administration, Improting Technology, Modcling Energy I'utures for the National Energy Strategy, SR/NES/90-01, U. S. Department of Energy, Washington, D.C. (1991).

Energy Information Administration, International Energy Anmual 1981, DOE/ EIA(0219(81), U. S. Department of Energy, Washington, D, C., October (1982).

Energy Information Administration, International Energy Annwal 1982, DOE/LIA0219(82), U. S. Department of Lnergy, Washington, D. C, September (1983).

Energy Information Administration, Intermational Energy Anmwal 1983, DOL/LIA0219(83), U. S. Department of Energy, Washington, D. C., November (1984).

Energy Information Administration, Intermational Encrgy Anmual 1984, DOL:/LiA0219(84), U. S. Department of Energy, Washington, D. C., October (1985).

Energy Information Administration, International Energy Annwal 1985, DOL:/LIA0219(85), U. S. Department of Energy, Washington, D. C., October (1986).

Energy Information Administration, Intermational Energy Anmual 1986, DOE/EIA02.19(86), U. S. Department of Energy, Washington, D. C., October (1987).

Energy Information Administration, International Energy Annual 1987, DOE/EIA0219(87), U. S. Department of Energy, Washington, D. C., October (1988).

Energy Information Administration, International Energy Anmual 1988, DOL:/liA0219(88), U. S. Department of Energy, Washington, D. C., November (1989). 
Linergy Information Administration, Intermational Energy Anmual 1989, DOLi/LIA()219(89), U. S. Department of Energy, Washington, D, C, March (1991),

Energy Information Administration, Natural Gas Annual 1987, Volume 1, DOE/ EIA0131(87)/1, U. S. Department of Energy, Washington, D. C, October (1988).

linergy Information Administration, Petroleum Supply Annual 1987, Volume 1, DOt:/EIA-0340(87)/1, U. S. Department of Energy, Washington, D. C, May (1988).

Invironmental Protection Agency, Office of Air and Radiation, Clean Air Act Amendments of 1990), Detailed Summary of 'Tittes, Washington, D. C., November 30 $(199())$.

Environmental Protection Agency, Office of Air and Radiation, Office of Mobile Sources, Analysis of the liconomic and Linnionmental Effects of Compressed Natural Cons us a Vilticle Fuel, Ann Arbor, Michigan, April (1990).

Environmental Protection Agency, Office of Air and Radiation, Office of Mobile Sources, Analysis of the Economic and Entimmmental Effects of Electricity as an Autumotize Fuel, Draft report, Ann Arbor, Michigan, August (1990).

Invironmental Protection Agency, Office of Air and Radiation, Office of Mobile Sources, Analysis of the Economic and Enrirommental Effects of Ethanol as an Automotine: I'uil, Ann Arbor, Michigan, April (1990)).

Invirommental Protection Agency, Office of Air and Radiation, Office of Mobile Sources, Analysis of the Economic and Linuironmental Effects of Methanol as an Automotion fiucl, Ann Arbor, Michigan, September (1989).

Invironmental Protection Agency, Office of Air and Radiation, Office of Mobile Sources, Compilation of Air Pollutant Emission Factors, Vol. II, Mobile Sources, Fonrth edition, AP-42, Research Triangle Park, North Carolina, September (1985).

Rnvironmental Protection Agency, Office of Air and Radiation, Compilation of Air Pollutant Emission Factors, Vol. II, Stationury Sultres, Fourth eddition, AP-42, Research Triangle Park, North Carolina, October (1988).

LIP: See Environmental Protection Agency.

D. Fisher, Potential Reductions in Greenhouse Gas Emissions from Alternatine Transportation Fuels, Draft report, Environmental Defense Fund, Oakland, California (|) |).

R. R. Camache and D. Golomb, The Relative Role of Methane und Carbon Dioxide in the Cirenlumse Effect, Final report, submitted to the American Gas Association, Arlington, Virginia, January (1990). 
M. J. Grubb, On Coefficients for Determining Greenhouse Gas Emissions from Fossil Fuel Production and Consumption, Energy and Environnient Program, Royal Institute of International Affairs, Londion, prepared for the IEA/OECD Expert Seminar on Energy Technologies for Reducing Emissions of Greenhouse Gases, Paris, April 1214 (1989).

D. E. Gushee, Carbon Dioxide Emissions from Methanol as a Vehicle Fuel, U. S. Library of Congress, Congressional Research Service, 88-14-S, Washington, D.C., January 4 (1988).

R. H. Hammerle, J. W. Shiller, and M. J. Shwarz, Global Warming, Ford Motor Company, Automotive Emissions and Fuel Economy Office, Michigan, September (1988).

W. Held, A. Konig, T. Richter, and L.. Puppe, "Catalytic NOx Reduction in Net Oxidizing Exhaust Gas," SAE Technical Paper Series, \#900496, Society of Automotive Engineers, Warrendale, Pennsylvania (1990).

S. P. Ho (Amoco Oil Company), "Global Warming Impact of Ethanol Versus Gasoline," presented at Clean Air Issues and America's Motor Fuel Business, Washington, D. C., October 3-5 (1989).

S. P. Ho and T. A. Renner, "The Global Warming Impact of Attainment Strategies Using Alternative Fuels," presented at the Air and Waste Management Conlerence on Troposphe:ic Ozone and Environment, Los Angeles, California, March 19-22 (1990).

IEA: See International Energy Agency.

International Energy Agency, Emission Controls in Electricity Generation and Intustry, Organization for Economic Cooperation and Development, Paris (1988).

International Energy Agency, Energy and the Environment, Policy Or'riew, Organization for Economic Cooperation and Development, Paris (1989).

International Energy Agency, Energy Statistics of OECD Countrit's 1987-1988, Organization for Economic Cooperation and Development, Paris (1990).

Interriational Energy Agency, Greenhouse Gas Emissions, the Energy Diml'nsion, Organization for Economic Cooperation and Development, Paris (1991).

International Energy Agency, Substitute Fuels for Road Transport, Organization for Economic Cooperation and Development, Paris (1990).

International Energy Agency, World Entrgy Statistics and Balances, 1985-1988, Organization for Economic Cooperation and Development, Paris (1990). 
R. A. Kerr, "How to Fix the Clouds in Greenhouse Models," Science 243:28-29 (1989).

T. Kudama, "Integrated Coal Fuel Cycle Analysis: Energy Consumption and Greenhouse Gas Emissions," Draft for the IPCC Workshop on Emissions of Greenhouse Gases, IEA/OECD, Paris, May 22-23 (1990).

T. Kudama, "Integrated LNG Fuel Cycle Analysis: Energy Consumption and Greenhouse Gas Emissions," Working document for ETSAP/IIASA Joint Workshop, Laxenburg, Austria, May 21-24 (1991).

D. A. Lashof and D. R. Ahuja, "Relative Contributions of Greenhouse Gas Fmissions to Global Warming," Nature 344:529-53i (1990).

M. C. MacCracken, "Greenhouse Gases: Changing the Nature of Our Environment," presented at Winter Meeting of the American Nuclear Society, San Francisco, November 29 (1989).

M. C. MacCracken and F. M. Luther, editors, Projecting the Climatic Effects of Imcrusing Carbon Dioxide, DOE/ER-0237, U. S. Department of Energy, Carbon Dioxide Research Division, Washington, D. C. (1985).

1. Mackenzie, Relative Releases of Carbon Dinxide fron. -veral Fuels, World Resources Institute, Washington, D. C., June 10 (1987).

J. D. Mahlman, "Mathematical Modeling of the Greenhouse Warming: How Much Do We Know," in Global Change ard Our Common Future, edited by R. S. Defries and T. F. Malone, National Academy Press, Washington, D. C. (1989).

G. Marland, "The Impact of Synthetic Fuels on Global Carbon Dioxide Emissions," in Carbon Dioxide Revieu: 1982, 406-410, edited by William. Clark, Clarendon Press, New York (1982).

G. Marland and A. Pippin, Emissions of Carbon Dioxide to the Earth's Atmosphere by Economic Activity, Oak Ridge National Laboratory, Tennessee, October (1990).

G. Marland and A. Turhollow, $\mathrm{CO}_{2}$ Emissions from Production and Combustion of Fuel Ethanol Made from Corn, ORNL/TM-1180, Oak Ridge National Laboratory, Tennessee, May (1990).

H. A. Mooney, P. M. Vitousek, and P. Matson, "Exchange of Materials between Terrestrial Ecosystems and the Atmosphere," Science 238:926-932 (1987).

D. Mortimer, Proposed Nuclear Power Station Hinkley Point C, Friends of the Earth, I.ondon, England (no date). 
E. A. Mueller, Consulting Engineers, Greenhouse Gas Emissions from Transportation Fuels, Draft for the U.S. Department of Energy, Office of Environmental Analysis, June (1990).

National Research Council, Changing Climate: Report of the Carbon Dioxide Assessment Committee, Executive Summary, National Academy Press, Washington, D. C. (1983).

North American Electric Reliability Council, 1989 Electricity Supply and Demand, I'rinceton, New Jersey, October (1989).

J. M. Ogden and R. H. Williams, Solar Hydrogen, Moving beyond Fossil Fuels, World Resources Institute, Washington, D. C., October (1989).

P. A. Okken, The Case for Alternative Transportation Fuels in the Context of Gre'nhouse: Gas Constraints, ECN-RX--90-046, The Netherlands Energy Research Foundation, Petten, The Netherlands, July (1990).

J. E. Penner, "Cloud Albedo, Greenhouse Effects, Atmospheric Chemistry, and Climate Change," Journal of the Air and Waste Management Association 40:456-461 (1990).

V. Ramanathan, "The Greenhouse Theory of Climate Change: A Test by an Inadvertent Global Experiment," Scienc' 240:293-299 (1988).

V. Ramanathan, R. J. Cicerone, H. B. Singh, and T. J. Kiehl, "Trace Gas Trends and Their Potential Role in Climate Change," Journal of Geophysical Research 90(D3):55475566 (1985).

D. M. Rastler, "Electric Power Research Institute's Role in Developing Fuel Cell Systems," Journal of Power Sources 29:47-57 (1990).

H. Rodhe, "A Comparison of the Contribution of Various Gases to the Greenhouse Effect," Science 248:1217-1219 (1990).

A. B. Rose, Energy Intensity and Related Parameters of Selected Transportation Modes: Freight Movements, ORNL-5554 (special companion to ORNL-5506), Oak Ridge National Laboratory, Tennessee, June (1979).

J. V. Ryan and R. K. Srivastava, EPA/IFP European Workshop on the Emission of Nitrous Oxide from Fossil Fuel Combustion, EPA-600/9-89-009, U. S. Environmental Protection Agency, Office of Research and Development, Washington, D. C., October (1989).

A. R. Sapre, "Properties, Performance, and Emissions of Medium Concentration Methanol-Gasoline Blends in a Single-Cylinder Spark-Ignition Engine," SAE Technical Paper Series, \#881679, Society of Automotive Engineers, Warrendale, Ponsolvinia (1988). 
M. Schwarz, "An Industry Perspective of Transportation and Global Warming," presented at the 69th Meeting of the Transportation Research Board, Washington, D. C., January 7-11 (1990).

M. Segal, Ethanol Fuel and Global Warming, 89-164 SPR, Congressional Research Service, The Library of Congress, Washington, D. C., March 6 (1989). (This is a review of Marland and Turhollow [1988]).

S. Seidel and D. Keyes, Can We Delay a Greenhouse Warming?, U. S. Environmental Protection Agency, Washington, D. C., November (1983).

K. I'. Shine, R. G. Derwent, D. J. Wuebbles, and J. J. Morcrette, "Radiative Forcing of Climate," in Climate Change, the IPCC Scientific Assessme'nt, 42-68, edited by J. T. Houghton, G. J. Jenkins, and J. J. Ephraums, Cambridge University Press, Cambridge, England (1990).

R. W. Spencer and J. R. Christy, "Precise Monitoring of Global Temperature Trends from Satellites," Science 247:1558-1562 (1990)).

D. A. Sperling and M. A DeLuchi, Alternatize Transportation Fuels and Air Pollution, report for the OECD Environment Directorate, Paris, March (1991).

Toyota Motor Corp., Product and Engineering Information Group, International Public Affairs Division, Toyota Engine Te'hnology, Tokyo, Japan, September (1989).

S. Unnasch, C. B. Moyer, D. D. Lowell, and M. D. Jackson, Comparing the Impact of Different Transportation Fuels on the Grenhouse Effect, P500-89-001, prepared for the California Energy Commission, Sacramento, California, March (1989).

U. S. Bureau of the Census: See U. S. Department of Commerce.

U. S. Congress, Office of Technology Assessment, Replacing Gasoline: Alternative Fuels for l.ight-Duty Vehicles, OTA-E-364, U. S. Government Printing Office, Washington, D. C., September (1990).

U. S. Department of Commerce, U. S. Bureau of the Census, 1987 Census of Mineral Industries, Subject Series, Fuels and Electric Encrgy Consumed, MIC87-S-2, Washington, D. C., December (1990).

U. S. Department of Energy, Assessment of Costs and Benefits of Flexible and Alternative Imel Use in the U. S. Transportation Sector, Technical Report Four: Vehicle and Fuel Distribution Requirements, August (1990)).

W.-C. Wang and G. Molnar, "A Model Study of Greenhouse Effects Due to Increasing Atmospheric $\mathrm{CH}_{4}, \mathrm{~N}_{2} \mathrm{O}, \mathrm{CF}_{2} \mathrm{Cl}_{2}$, and $\mathrm{CFCl}_{3}$," Journal of Geoplysical Reserurch 90(D7):12791-12980 (1985). 
W.-C. Wang, D. Wuebbles, and W. M. Washington, "Potential Climatic Effects of Perturbations Other Than Carbon Dioxide," in Projecting the Climatic Leffects of Increasing Carbon Dioxide, DOE/ER-0237, 191-236, edited by Michael C. MacCracken and Frederick M. Luther, U. S. Department of Energy, Washington D. C., December (1985).

C. S. Weaver, Natural Gas Vehicles: A Review of the State of the Art, Sierra Research, Sacramento, California, April 13 (1989).

R. F. Webb, personal communication, August 17 (1990).

H. M. White, Assessment of Alternative Automotive Fuels Impact on $\mathrm{CO}_{2}$ Emissions, The Aerospace Corporation, Mobile Systems Directorate, Los Angeles, California, for the U. S. Department of Energy, September (1980).

R. H. Williams and E. D. Larson, "Expanding Roles for Gas Turbines in Power Generation," in Eiectricity, 505-553, edited by T. B. Johansson, B. Bodlund, and R. H. Williams, Lund University Press, Lund, Sweden (1989).

D. Wilson, "Quantifying and Comparing Fuel-Cycle Greenhouse Gas Emissions -Coal, Oil, and Natural Gas Consumption," Energy Policy 18:550-562 (1990). 

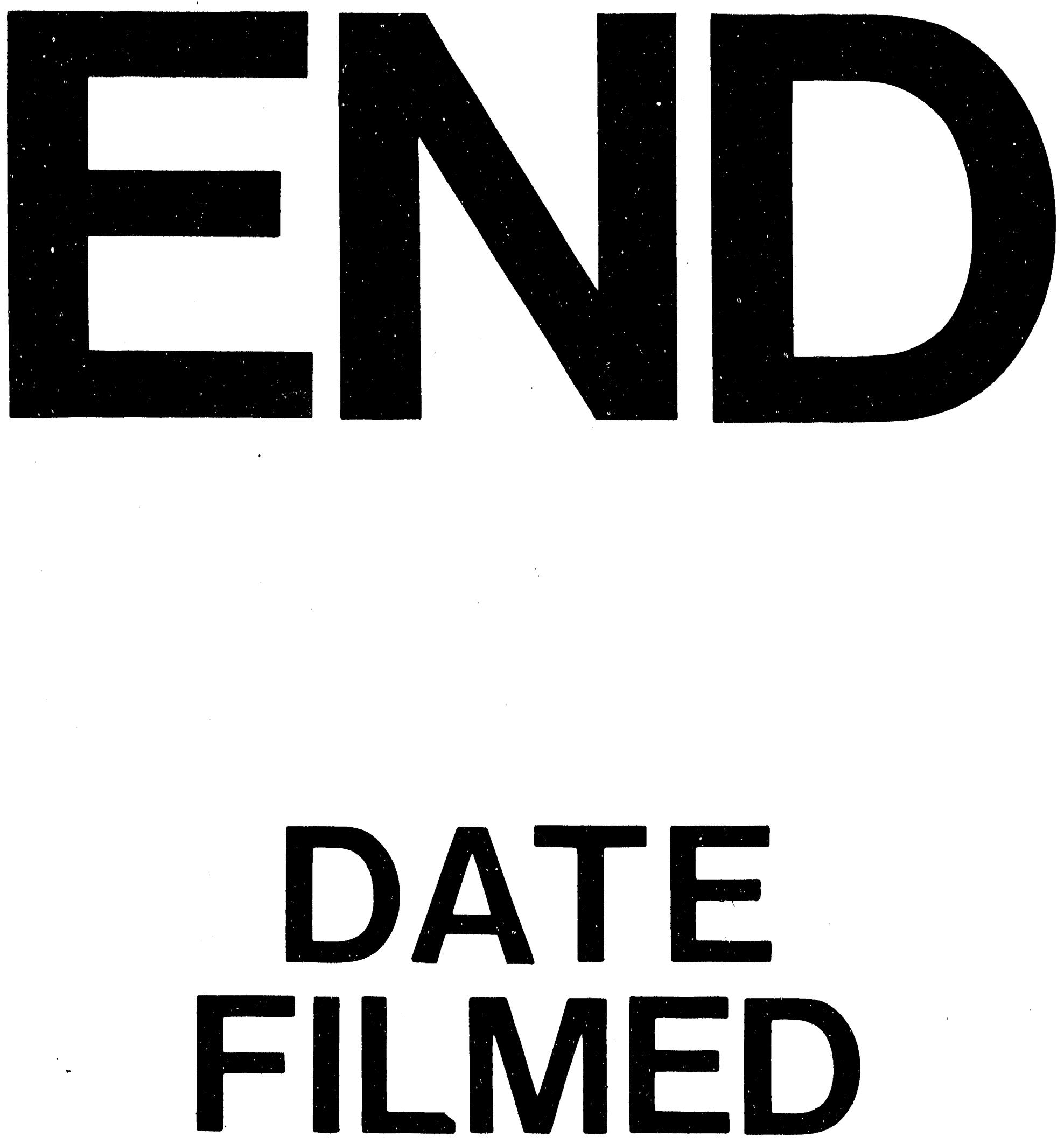

1

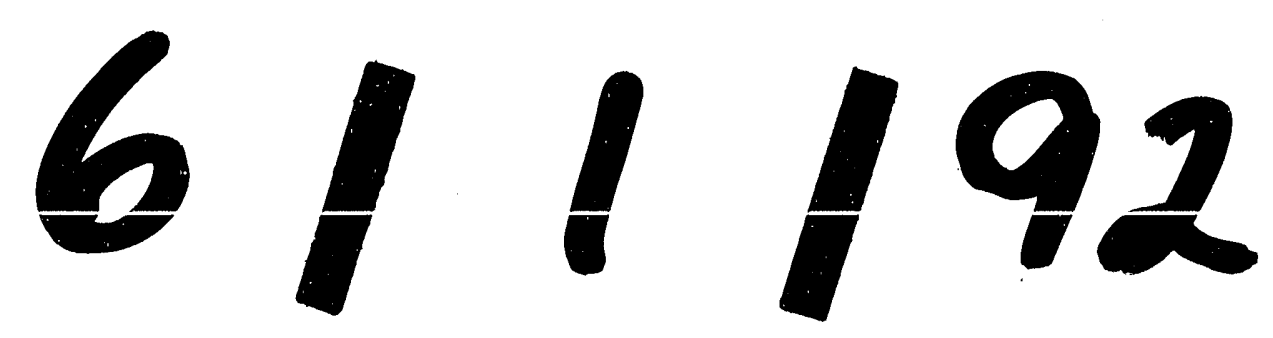


